MARCUS VINICIUS WEBER DE CAMPOS

Avaliação da interação solo-reforço por meio de ensaios de cisalhamento cíclico de interface

Orientador: Prof. Dr. Orencio Monje Vilar 



\section{MARCUS VINICIUS WEBER DE CAMPOS}

\section{Avaliação da interação solo-reforço por meio de ensaios de cisalhamento cíclico de interface}

Dissertação apresentada à Escola de Engenharia de São Carlos da Universidade de São Paulo, como parte dos requisitos para a obtenção do titulo de Mestre em Geotecnia. 
AUTORIZO A REPRODUÇÃO TOTAL OU PARCIAL DESTE TRABALHO, POR QUALQUER MEIO CONVENCIONAL OU ELETRÔNICO, PARA FINS DE ESTUDO E PESQUISA, DESDE QUE CITADA A FONTE.

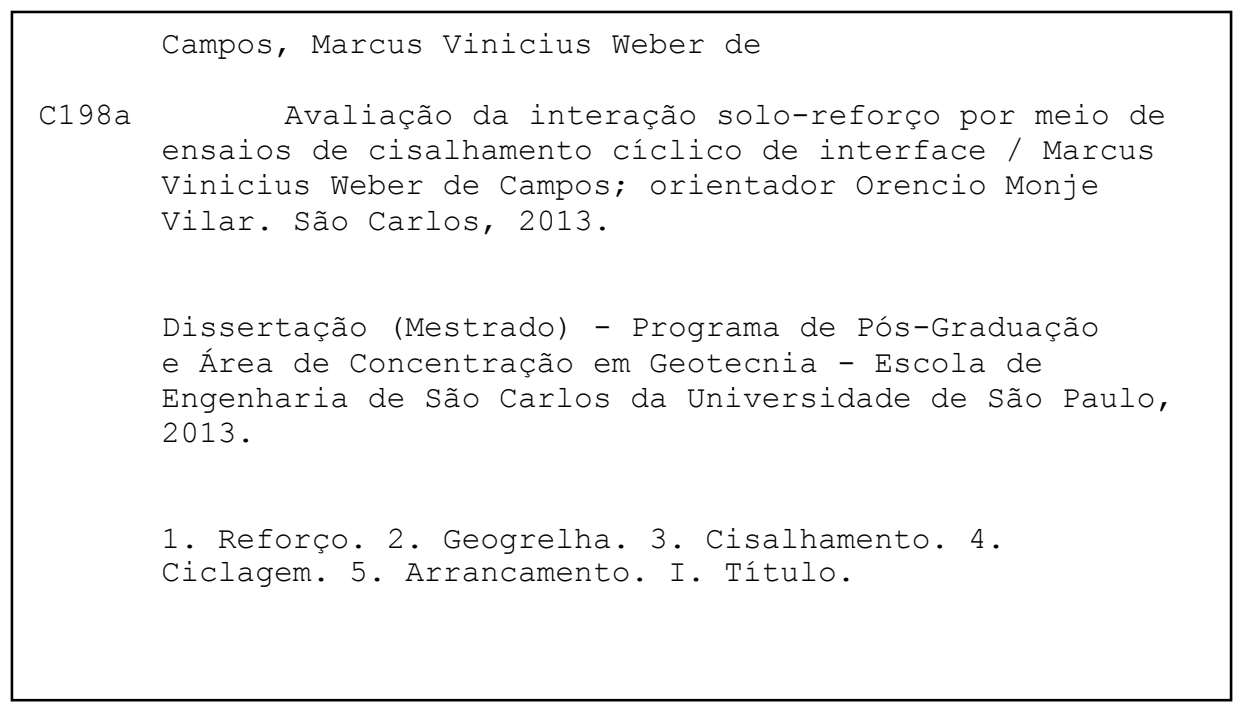




\section{FOLHA DE JULGAMENTO}

Candidalo: Bacharel MARCUS VINICIUS WEBER DE CA YPOS.

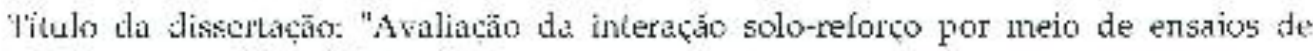
cisalhamento ciclico de interlace"

Data da defesu: $1: 1,10 / 2013$

\section{Conissāo Iulgadorn:}

Prol. Tiltular Orencio Monje Vilar (Orientador)

(Escola de Engenfaria de Sẫo CarlosiEESC)

Prof, Dr. GIauco Túlio Pessa Fabri

(Escola de Engentharia de Sño CarlosiEESC)

Prof. Dr. Marcos Antonio Garcia Ferreira

(Universidade Federal de Säo Carlos:LFSCar)

Ciordenador do l'rograma de l'ós-Giraduaçāo cm Ceotecnia:

Prol. Titular Osní José Pejon

l'resitlente da Comissāo de l'ós-Graduaçâo:

l'rol. 1 ilular Denis Vinicius Coury
Resultadu:

APROVDDO

Armevingos

A AROW400 

À minha avó Helena por seu amor e apoio incondicional em todas as fases da minha vida. 



\section{Agradecimentos}

Agradeço a Deus pela saúde que me foi dada e por todas as minhas conquistas na vida.

Aos meus pais Edison e Judith que dedicaram suas vidas aos filhos com amor e apoio incondicional em toda a vida.

A Letícia, minha namorada, que me acompanhou desde o final da graduação, apoiando e incentivando com muito amor e carinho mais esta jornada da minha vida.

Aos meus irmãos e amigos que me apoiaram e me ajudaram durante os momentos difíceis e me acompanharam em várias comemorações.

Ao Prof. Benedito de Souza Bueno por sua orientação, apoio, incentivo e oportunidades desde a época de estágio no Laboratório de Geossintéticos, deixando muitos ensinamentos valiosos.

Ao Prof. Orencio Monje Vilar por seu apoio e orientação desde a época de estágio e principalmente durante a pesquisa, viabilizando grande parte do trabalho.

Aos amigos da minha turma de mestrado que me acompanharam nos esforços para superar com grandiosidade esta fase acadêmica.

Aos funcionários do departamento de Geotecnia Maristela, Álvaro, Neiva, Zé Luiz, Oscar, Antônio, Benedito e Décio, e do laboratório de Geossintéticos Walter, Manoel, Clever, Marcão e Thiago pelo apoio e ajuda durante o estágio e a pesquisa.

Aos meus amigos Francisco, Jorge, Fernando, Natalia, Gian, Ana Elisa e Fagner que me ajudaram durante a realização da pesquisa com ideias, apoio teórico e prático.

As empresas Maccaferri, Huesker e Pedreira Bandeirantes pela doação de materiais para a pesquisa.

Ao CNPq pela bolsa concedida durante o mestrado. 

"Quanto mais sei, mais sei que nada sei.."

Sócrates 



\section{RESUMO}

CAMPOS, M. V. W. Avaliação da interação solo-reforço por meio de ensaios de cisalhamento cíclico de interface. 2013. 192 f. Dissertação (Mestrado) - Escola de Engenharia de São Carlos, Universidade de São Paulo, São Carlos, 2013.

O comportamento de solos reforçados depende amplamente da interação entre o solo e o reforço, baseado nas solicitações que o conjunto experimentará ao longo da sua vida útil. Tal interação é comumente caracterizada através de ensaios normatizados como o de arrancamento, que buscam simular as solicitações a que o conjunto estará sujeito. Porém, algumas estruturas reforçadas experimentam ações cíclicas de cargas móveis consideráveis, que dificilmente tem seu comportamento representado nestes ensaios comuns. Diante disso, esta pesquisa buscou aperfeiçoar o equipamento de ensaios cíclicos da Escola de Engenharia de São Carlos EESC-USP, a fim de realizar ensaios cíclicos em diferentes tipos de solos (uma areia, um silte argiloso e uma brita graduada simples), reforçados com uma geogrelha de poliéster comumente utilizada para reforço de base de pavimentos. Após esta etapa se iniciaram os ensaios de arrancamento nos solos, fornecendo parâmetros para a realização dos ensaios cíclicos. No arrancamento a areia apresentou ganho de resistência com o aumento da tensão confinante, e os maiores deslocamentos, já o silte e a brita não sofreram influência deste aumento. O comportamento cíclico causou desconfinamento da areia e degradação do reforço na brita, apresentando o comportamento mais estável no silte. Durante os ensaios o reforço apresentou grandes deformações conforme solicitado, o que contribuiu para os valores de módulos de resiliência abaixo dos descritos na literatura, que utiliza corpos de prova curtos e diferentes níveis de tensões. Nos ensaios cíclicos a areia variou seu módulo relativamente pouco com as variações de tensão confinante e cisalhante, o silte foi mais sensível à variação da cisalhante e a brita variou igualmente com as duas.

Palavras chave: Reforço, Geogrelha, Cisalhamento, Ciclagem, Arrancamento. 



\begin{abstract}
CAMPOS, M. V. W. Avaliação da interação solo-reforço por meio de ensaios de cisalhamento cíclico de interface. 2013. 192 f. Dissertação (Mestrado) - Escola de Engenharia de São Carlos, Universidade de São Paulo, São Carlos, 2013.
\end{abstract}

The behavior of reinforced soils depends largely on the interaction between soil and reinforcement, based on requests that the group will experience throughout its service life. Such interaction is commonly characterized by standardized tests such as the pullout, which seek to simulate the stresses to which the group is subject. However, some reinforced structures experience cyclic loads by considerable moving loads, that their behavior is hardly represented in these common tests. Thus, this research sought to improve the equipment of cyclic tests of the School of Engineering of São Carlos EESC-USP, in order to perform cyclic tests on different types of soil (one sand, clayey silt and a simple graded gravel), reinforced with one polyester geogrid commonly used for reinforcing pavements base. After this step began the pullout tests on soils, providing parameters for the realization of the cyclic tests. In the pullout tests, the sand had resistance gain with confining tension increasing and greater displacements, already silt and gravel not affected by this increase. The cyclical behavior caused deconfinement of sand, and the gravel causes degradation of reinforcement, with the more stable behavior on silt. During the test, the reinforce presented large deformations as requested, which contributed to the values of resilience modules below in the literature, which uses specimens shorter and different tension levels. In the cyclic tests the sand modulus varied relatively little with confining pressure and shear variations, the silt was more sensitive to the variation of shear and gravel also varied with both.

Keywords: Reinforcement, Geogrid, Shear, Cycling, Pullout. 



\section{Lista de Figuras}

Figura 2.1 - Curvas tensão-deformação e determinação do módulo de elasticidade (E) e resiliente $(\mathrm{Mr})$ 7

Figura 2.2 - Equipamento triaxial cíclico (Adaptado de MARMITT et al., 2010).........8

Figura 2.3 - Relações tensão-deformação de histerese a diferentes magnitudes de deformação (Adaptado de SEED, 1970).

Figura 2.4 - Relação não linear entre (a) tensão e deformação e (b) degradação do módulo de elasticidade com o aumento da deformação (Modificado de ATKINSON, 2000). 10

Figura 2.5 - Definições de termos de módulo de Resiliencia (Adaptado de NCHRP, 2004)

Figura 2.6 - Deformações a cargas baixas repetidas (MENDOZA, 2003)...................12

Figura 2.7 - Elementos constituintes de uma geogrelha (KAKUDA, 2005). 15

Figura 2.8 - Comportamento termo-visco-elasto-plástico onde (a) Elasto-Plástico, (b) Termo-Viscoso, (c) Anisitrópico, (d) Comportamento cíclico Tensão-Deformação (Adaptado de PERKINS, 2000).

Figura 2.9 - Seção de pavimento betuminoso. CBUQ = Concreto betuminoso usinado a quente; BGS = Brita graduada simples; Fornit $=$ Geogrelha específica utilizada; Hate $=$ Geotêxtil tecido específico utilizado (CARMO, 2011). 18

Figura 2.10 - Distribuições das tensões com camadas em um pavimento flexível (a) área de altas tensões diretamente abaixo do carregamento da roda; (b) redução do carregamento ao nível do subleito (Adaptado de GUPTA, 2009)

Figura 2.11 - Magnitudes de cargas relativas no nível da camada de sub-leito para: (a) Pavimento flexível não reforçado e (b) Pavimento flexível reforçado com geossintético (Adaptado de GUPTA, 2009). 
Figura 2.12 - Mecanismo de reforço de confinamento lateral (Adaptado de USACE, 2003).

Figura 2.13 - Mecanismo de reforço de melhora de capacidade de carga (Adaptado de USACE, 2003).

Figura 2.14 - Mecanismo de reforço de efeito de membrana tencionada (Adaptado de USACE, 2003). 24

Figura 2.15 - Ancoragem da geogrelha (Adaptado de KOERNER, 2005). 27

Figura 2.16 - Detalhe de confinamento da região de interface solo-geogrelha (KAKUDA, 2005).

Figura 2.17 - Exemplo de carregamento cíclico em geossintéticos (Aterro íngreme e Dolinas) de Mayer (2004). 28

Figura 2.18 - Esquema do ensaio de arrancamento. 30

Figura 2.19 - Fixação de instrumentação para medição de deslocamentos (Adaptado de GUPTA, 2009). 31

Figura 2.20 - Força de arrancamento frontal versus curvas de deslocamento dos LVDT's 1, 2, 3, 4 e 5 (Adaptado de GUPTA, 2009). 32

Figura 2.21 - Força de arrancamento frontal em função do tempo de ensaio, e deslocamento em função to tempo de ensaio (Adaptado de GUPTA, 2009). 33

Figura 2.22 - Deslocamentos ao longo do corpo de prova; Transferência de força de tração (a) e fase de arrancamento (b) (Adaptado de MORACI, 2006). 34

Figura 2.23 - Resistência ao arrancamento com e sem elementos transversais (TEIXEIRA, 2003) 35

Figura 2.24 - Deformação dos membros longitudinais (Adaptado de PALMEIRA, 2009). 36 
Figura 2.25 - Ciclagem PET (a) e ciclagem PEAD (b) a $80 \% \mathrm{~F}_{\text {máx }}$ (Modificado de BATHURST, 1994). 38

Figura 2.26 - Funcionamento da ciclagem e módulo de cisalhamento de interface (Adaptado de CUELHO e PERKINS, 2005).

Figura 2.27 - Vista em planta da caixa de arrancamento (Adaptado de CUELHO e PERKINS, 2005).

Figura 2.28 - Procedimento de carregamento de arrancamento cíclico (Adaptado de CUELHO e PERKINS, 2005).

Figura 2.29 - Comparação entre casos extremos de ciclagens (40 e 80\%) em relação à resistência monotônica (GARCÍA, 2011). 45

Figura 2.30 - Resistência ao arrancamento em ensaios de controle de carga (LC) e controle de deslocamento (DC) à frequência de 0,01 Hz (Adaptado de RAJU, 1997). .46

Figura 2.31 - Vista lateral de um dispositivo de ensaio típico (Adaptado de ASTM 7499, 2009).

Figura 2.32 - Dados cronometrados e (a) calculo manual do $G_{i}$ em cargas baixas e (b) dados cronometrados com altas cargas cisalhantes (Adaptado de HOLLEY, 2009).

Figura 2.33 - Ensaios de ciclagem em geogrelha PET, Testes C1 e C2 (semelhantes), com tensões de 15,5 a 103,4 kPa (Adaptado de HOLLEY, 2009).

Figura 2.34 - Módulo de cisalhamento de interface versus tensão cisalhante para vários confinamentos, geogrelha na direção longitudinal (Adaptado de CUELHO e PERKINS, 2005). .52

Figura 3.1 - Esquema de funcionamento do equipamento de arrancamento e ensaios cíclicos. .55

Figura 3.2 - Equipamento com caixa de arrancamento e ciclagem confinada de reforços. 56 
Figura 3.3 - Bolsa de ar para aplicação de tensão confinante.

Figura 3.4 - Célula de carga acoplada ao pistão hidráulico para carregamento cisalhante. 58

Figura 3.5 - (a) Laterais de fixação reforçadas e núcleo (parte central) da garra; (b) detalhe da nervura de reforço. 59

Figura 3.6 - (a) Área de trabalho inicial; (b) Área de trabalho de programação ("Config.") de ensaios. 60

Figura 3.7 - (a) Mesa de fixação dos sensores; (b) Detalhe do sensor; (c) Posicionamento dos sensores na mesa.

Figura 3.8 - Válvula dupla controladora de fluxo de óleo.

Figura 3.9 - Posicionamento das células de tensão total para calibração. 65

Figura 3.10 - Disposição do LVDT durante calibração. 66

Figura 3.11 - Ciclagem com velocidade do pistão variável. 68

Figura 3.12 - Variação de amplitude de carga. 69

Figura 3.13 - Variação da pressão do óleo. 71

Figura 3.14 - Variação da vazão 72

Figura 3.15 - Geogrelha utilizada na pesquisa. 75

Figura 3.16 - Ensaio de tração em geogrelha, na direção longitudinal. ....................... 76

Figura 3.17 - Ensaio de tração em geogrelha, na direção transversal. ......................... 77

Figura 3.18 - Curva granulométrica da areia utilizada na pesquisa. .......................... 80

Figura 3.19 - Compactador manual utilizado na areia e brita.................................. 81

Figura 3.20 - Aferição de compacidade da areia, do silte e da brita............................ 82

Figura 3.21 - Brita graduada simples utilizada na pesquisa....................................... 84

Figura 3.22 - Curva granulométrica da brita utilizada. ............................................. 84

Figura 3.23 - Silte argiloso utilizado na pesquisa. ..................................................... 86 
Figura 3.24 - Compactador manual utilizado no silte. .89

Figura 3.25 - Detalhe da fixação dos fios dos transdutores de deslocamentos 91

Figura 3.26 - Layout A dos pontos de medição de deslocamentos da geogrelha. ........92

Figura 3.27 - Layout B dos pontos de medição de deslocamentos da geogrelha.........93

Figura 3.28 - Corte vertical da caixa de ensaios com a distribuição das células de tensão total. 94

Figura 4.1 - Curvas de força de arrancamento versus deslocamento da garra em areia.

Figura 4.2 - Deslocamento dos sensores ao longo da amostra durante ensaio com tensão, $\sigma$, de $40 \mathrm{kPa}$ em areia (Ensaio AA4). .96

Figura 4.3 - Solicitações ao longo do corpo de prova em ensaio de arrancamento com tensão, $\sigma$, de $40 \mathrm{kPa}$ em areia (Ensaio AA4). .97

Figura 4.4 - Arrancamento com tensão, $\sigma$, de $55 \mathrm{kPa}$ em areia (Ensaio AA3). .98

Figura 4.5 - Envoltória de resistência ao arrancamento em areia. 100

Figura 4.6 - Níveis de carregamento e deslocamento no ensaio cíclico com areia. ... 102

Figura 4.7 - Carga de ciclagem, deslocamento pontual e tensão total versus tempo com $40 \%$ da $\mathrm{F}_{\text {máx }}$ e tensão, $\sigma$, de $40 \mathrm{kPa}$ 104

Figura 4.8 - Deslocamento registrado nos medidores D1 a D6 no último ciclo da tensão confinante de $40 \mathrm{kPa}$ e $40 \%$ da $\mathrm{F}_{\text {máx }}$ em areia. 105

Figura 4.9 - Ciclagem completa com $40 \%$ da $\mathrm{F}_{\text {máx }}$ e tensão, $\sigma$, de $40 \mathrm{kPa}$ em areia. 106 Figura 4.10 - (a) Ciclos de 20, 40 e $60 \%$ da $\mathrm{F}_{\text {máx }}$ com tensão, $\sigma$, de $40 \mathrm{kPa}$; (b) Ciclo $20 \%$ da $\mathrm{F}_{\text {máx }}$ e tensão, $\sigma$, de $40 \mathrm{kPa}$; (c) $40 \%$ da $\mathrm{F}_{\text {máx }}$ e tensão, $\sigma$, de $40 \mathrm{kPa}$; (d) $60 \%$ da $\mathrm{F}_{\text {máx }}$ e tensão, $\sigma$, de $40 \mathrm{kPa}$ e módulo de resiliência (reta) da areia. 107

Figura 4.11 - Reforço cisalhado em areia (Ensaio CA2). 108 
Figura 4.12 - Módulo de resiliência de interface $\left(\mathrm{G}_{\mathrm{i}}\right)$ versus Tensão cisalhante $(\tau)$ em areia.

Figura 4.13 - Curvas força de arrancamento versus deslocamento da garra para silte.

Figura 4.14 - Deslocamento dos sensores ao longo da amostra durante ensaio de arrancamento em silte com tensão, $\sigma$, de $55 \mathrm{kPa}$ (Ensaio AC3).

Figura 4.15 - Solicitações ao longo do corpo de prova em ensaio de arrancamento com tensão, $\sigma$, de $55 \mathrm{kPa}$ (Ensaio AC3).

Figura 4.16 - Arrancamento com tensão, $\sigma$, de $40 \mathrm{kPa}$ em silte (Ensaio AC2).

Figura 4.17 - Níveis de carregamento e deslocamento em silte.

Figura 4.18 - Carga de ciclagem, deslocamento pontual e tensão total versus tempo no ensaio com silte, Força de $60 \%$ da $F_{\text {máx }}$ e tensão, $\sigma$, de $40 \mathrm{kPa}$.

Figura 4.19 - Deslocamento registrado nos medidores D1 a D6 no último ciclo da tensão de $40 \mathrm{kPa}$ e $40 \%$ da $\mathrm{F}_{\text {máx }}$ em silte.

Figura 4.20 - Ciclagem completa a $40 \%$ da $\mathrm{F}_{\text {máx }}$ e tensão, $\sigma$, de $40 \mathrm{kPa}$ em silte..... 121

Figura 4.21 - (a) Ciclos de 20, 40, 60 e $80 \%$ da $F_{\text {máx }}$; (b) Ciclo com nível de $20 \%$ da $\mathrm{F}_{\text {máx }}$; (c) Nível de $40 \%$ da $\mathrm{F}_{\text {máx }}$; (d) Nível de $60 \%$ da $\mathrm{F}_{\text {máx }}$; (e) Nível de $80 \%$ da $\mathrm{F}_{\text {máx }}$ e projeção do módulo de resiliência (reta) para tensão de $40 \mathrm{kPa}$ em silte.

Figura 4.22 - Reforço cisalhado no silte (Ensaio CC1). 123

Figura 4.23 - Modulo de resiliência $\left(G_{i}\right)$ de interface versus tensão cisalhante $(\tau)$ em silte. 124

Figura 4.24 - Curvas força de arrancamento versus deslocamento da garra em brita.125

Figura 4.25 - Deslocamento dos sensores ao longo da amostra durante arrancamento com tensão, $\sigma$, de $40 \mathrm{kPa}$ em brita (Ensaio AB2). 126 
Figura 4.26 - Solicitações ao longo do corpo de prova em ensaio de arrancamento com tensão, $\sigma$, de $40 \mathrm{kPa}$ em brita (Ensaio $\mathrm{AB} 2$ ).

Figura 4.27 - Arrancamento com tensão, $\sigma$, de 40 kPa em brita (Ensaio AB2). .........128

Figura 4.28 - Níveis de carregamento e deslocamento da amostra em brita.

Figura 4.29 - Carga de ciclagem, deslocamento pontual e tensão total versus tempo de ensaio, com $40 \%$ da $\mathrm{F}_{\text {máx }}$ e tensão, $\sigma$, de $40 \mathrm{kPa}$ brita. 133

Figura 4.30 - Deslocamento registrado nos medidores D2 a D5 no último ciclo da tensão confinante de $40 \mathrm{kPa}$ e $40 \%$ da $\mathrm{F}_{\text {máx }}$ em brita.

Figura 4.31 - Ciclagem completa a $40 \%$ da $F_{\text {máx }}$ e tensão, $\sigma$, de $40 \mathrm{kPa}$ em brita..... 135

Figura 4.32 - (a) Ciclos de 20, 40 e $60 \%$ da $\mathrm{F}_{\text {máx }}$; (b) Ciclo nível $20 \%$ da $\mathrm{F}_{\text {máx }}$; (c) Nível 40 \% da $\mathrm{F}_{\text {máx }}$ (d) Nível 60 \% da $\mathrm{F}_{\text {máx }}$ e módulo de resiliência (reta) para ensaios com 40 $\%$ da $\mathrm{F}_{\text {máx }} \mathrm{e}$ tensão, $\sigma$, de $40 \mathrm{kPa}$ em brita.

Figura 4.33 - Reforço cisalhado em brita (Ensaio CB2).

Figura 4.34 - Modulo de resiliência $\left(\mathrm{G}_{\mathrm{i}}\right)$ de interface versus tensão cisalhante $(\tau)$ na brita. 138

Figura 7.1 - Tela inicial do CLP. 154

Figura 7.2 - Tela "Config." do CLP. 154

Figura 7.3 - Tela "Carga" do CLP. 155

Figura 7.4 - Tela "Ciclo" do CLP. 156

Figura 7.5 - Tela "Curso" do CLP. 157

Figura 7.6 - Tela "Controle" do CLP. 158 



\section{Lista de Tabelas}

Tabela 2.1 - Porcentagem de cargas de falhas para cada sequencia de grupo (Adaptado de CUELHO e PERKINS, 2005).

Tabela 3.1 - Caracterização geométrica da geogrelha. .75

Tabela 3.2 - Resultados de ensaio de tração na geogrelha, na direção longitudinal.....77

Tabela 3.3 - Resultados de ensaio de tração na geogrelha, na direção transversal........78

Tabela 3.4 - Parâmetros da areia utilizada.

Tabela 3.5 - Características do Silte. 87

Tabela 3.6 - Características dos ensaios de arrancamento. 90

Tabela 4.1 - Resultados de arrancamento em areia, silte e brita. 140

Tabela 4.2 - Comportamento cíclico da areia, do silte e da brita. 



\section{Lista de Abreviaturas}

ABNT - Associação Brasileira de Normas Técnicas

ASTM -American Society for Testing and Materials

DNER - Departamento Nacional de Estradas e Rodagens

DNIT - Departamento Nacional de Infraestruturas de Transportes

EESC - Escola de Engenharia de São Carlos

FEM - Finite Elements Method

FHWA - Federal Highway Administration

FV - Fibra de Vidro

LVDT - Linear Variable Displacement Transducer

NBR - Norma Brasileira

NCHRP - National Cooperative Highway Research Program

PA - Poliamida (Náilon)

PE - Polietileno

PET - Poliéster

PP - Polipropileno

PVC - Policloreto de vinila

USACE - United States Army Corps of Engineers

USP - Universidade de São Paulo 



\section{Lista de Símbolos}

$E$ - Módulo de elasticidade

$F_{\text {máx }}$ - Força máxima de arrancamento

$G_{i}$ - Módulo de resiliência de cisalhamento de interface

$l$ - Comprimento

Mr - Módulo de resiliência

$w$ - Largura

$\gamma-$ Peso específico

$\Delta$ - Deslocamento

$\varepsilon-$ Deformação

$\sigma-$ Tensão confinante

$\tau$ - Tensão cisalhante 



\section{Sumário}

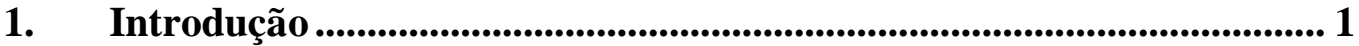

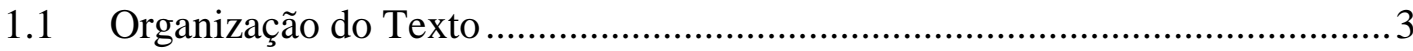

2. Revisão da literatura ....................................................................... 4

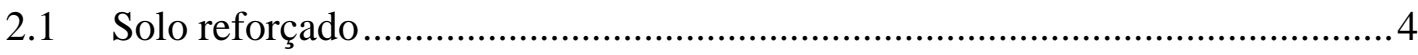

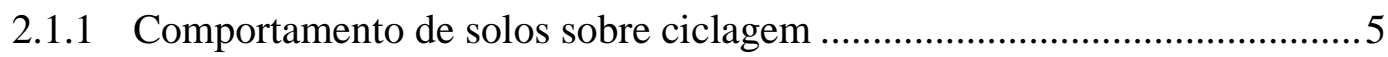

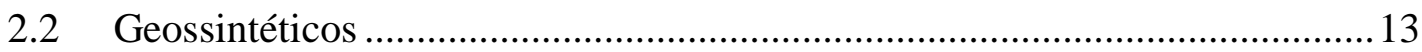

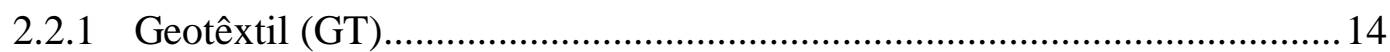

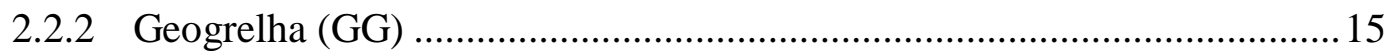

2.2.3 Comportamento dos geossintéticos .......................................................16

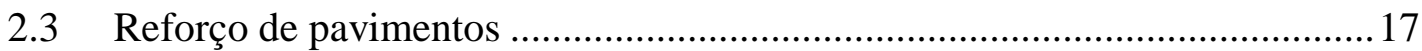

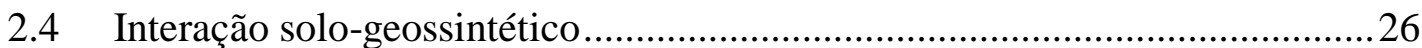

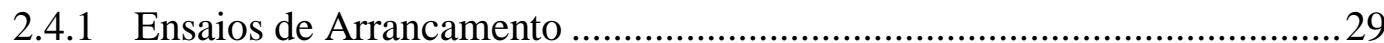

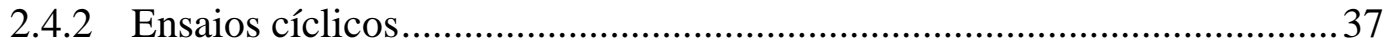

3. Materiais e Métodos ...................................................................................5 54

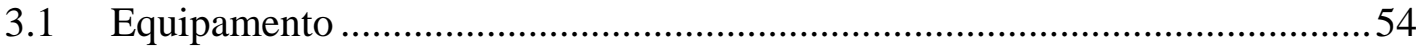

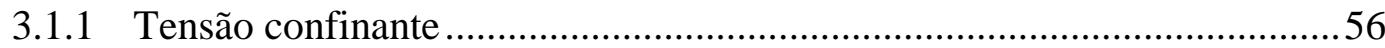

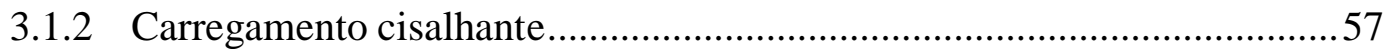

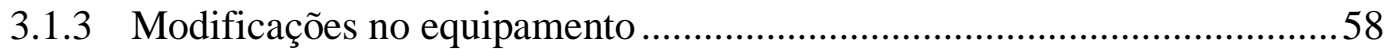

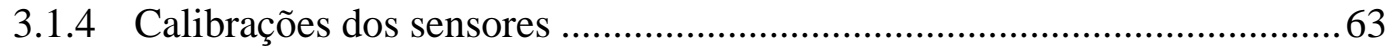

3.1.5 Calibrações do Controlador Lógico Programável e equipamento .............67 


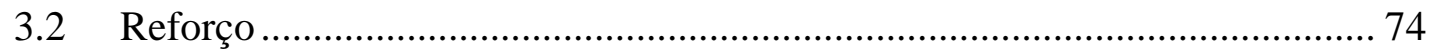

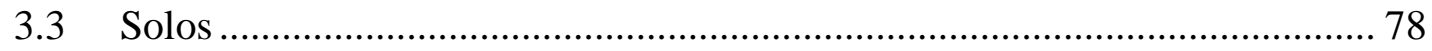

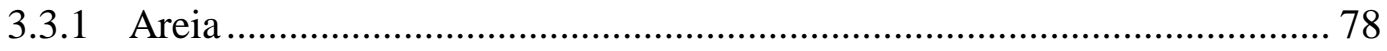

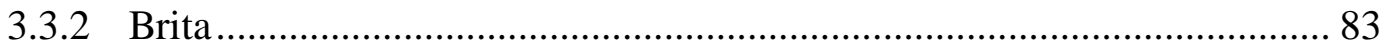

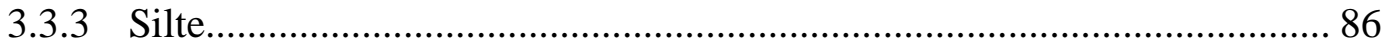

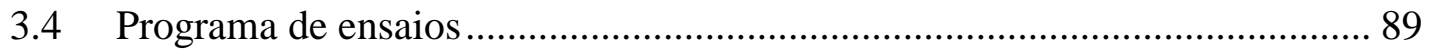

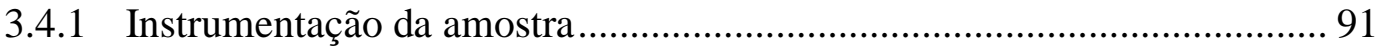

4. Resultados e Discussões ..........................................................................95

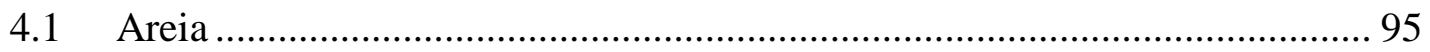

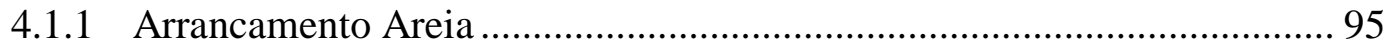

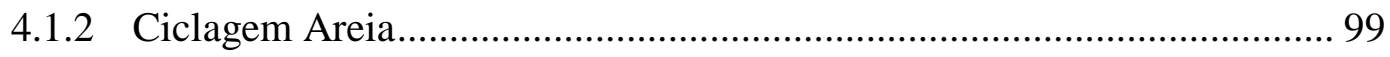

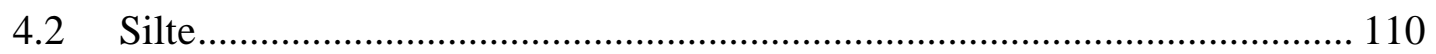

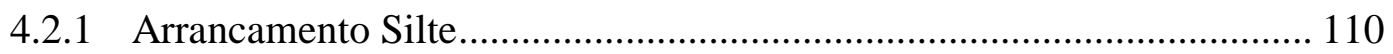

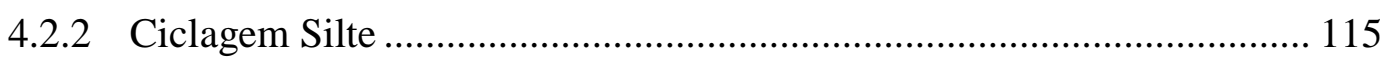

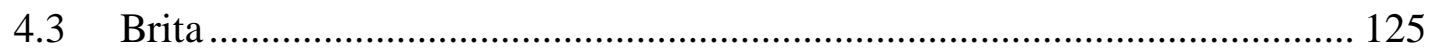

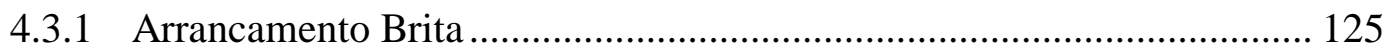

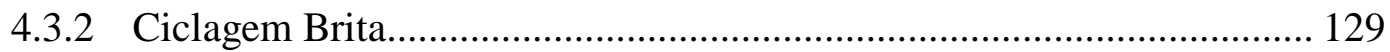

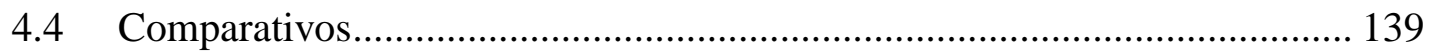

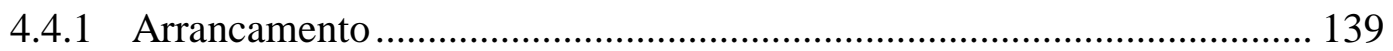

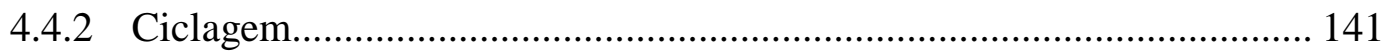


5. Conclusão

146

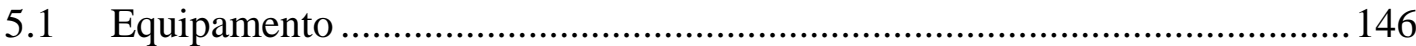

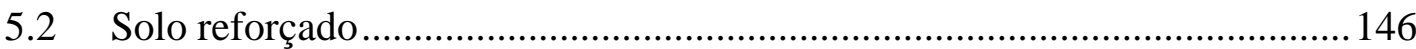

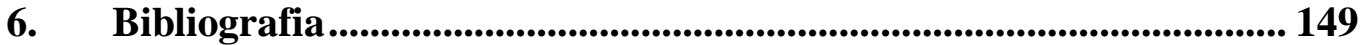

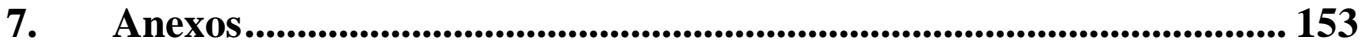

7.1 Programações do CLP do equipamento de ensaios de arrancamento e cíclicos 153 



\section{Introdução}

Um sistema de solo reforçado compreende o uso do solo propriamente dito e de um elemento de reforço como uma geogrelha, um geotêxtil ou mesmo a composição dos dois, havendo ainda a opção de utilizar tiras metálicas ou outros materiais que possam cumprir a função de reforço. Entre os geossintéticos, o material que tem essa como sua principal função é a geogrelha, já os geotêxteis são utilizados para funções de reforço e ainda separação, filtração e drenagem. A funcionalidade e a estabilidade desses sistemas dependem em larga escala da interação que se desenvolve entre o solo e o elemento de reforço.

Sistemas de solo reforçado são comumente utilizados na construção de estruturas de arrimo e na melhoria da capacidade de suporte de solos de baixa resistência. Estes sistemas estão sujeitos a vários tipos de carregamentos, como cargas estáticas decorrentes do peso próprio da estrutura e de eventuais sobrecargas e cargas cíclicas, tal como pode ocorrer num sistema de solo reforçado utilizado como base de um pavimento ferroviário ou rodoviário, por exemplo. Sendo assim, o comportamento dos materiais (solo, reforço e do conjunto) pode apresentar diferentes reações após a construção, necessitando de tal caracterização, assim como de parâmetros quantitativos a respeito de resistência, deformabilidade, interação e compatibilidade entre os materiais que o compõe.

Para a quantificação desta interação entre o solo e o reforço podem ser utilizados ensaios de cisalhamento direto de interface, de arrancamento, ou ainda de compressão triaxial, caracterizando-se a interação entre os elementos por meio de carregamentos estáticos. Carregamentos cíclicos apresentam mecanismos de solicitação diferentes, com resultados que podem se afastar dos fornecidos pelos ensaios usuais de arrancamento estático. Logo, surge a necessidade de se caracterizar o comportamento cíclico de solos reforçados através de um 
ensaio que simule tal condição. Os ensaios cíclicos de cisalhamento de interface solo-reforço podem fornecer estes parâmetros de interação entre os dois, representando as solicitações de campo de reforços sujeitos à ciclagem. Nessa perspectiva, é possível, por meio de ensaios cíclicos, estudar diferentes aspectos da interação solo-reforço, como o acúmulo de deformações plásticas e a recuperação de deformações elásticas, usualmente expressas pelo módulo de resiliência de cisalhamento de interface. Esta propriedade é útil nos modernos métodos de dimensionamento de pavimentos reforçados, que empregam conceitos mecanicistas, como o método desenvolvido (PERKINS et al., 2004). A respeito do desenvolvimento do método, ainda são poucos os trabalhos que se dedicam a determinar essa propriedade, provavelmente, por conta das dificuldades laboratoriais envolvidas. Algumas informações disponíveis na literatura ressaltam as diferenças entre geogrelhas de diferentes composições, como as de polietileno de alta densidade (PEAD) e as de poliéster (PET), em função, principalmente de suas diferentes deformabilidades. Outros estudos apontam para a influência da tensão normal e do nível de tensão cisalhante aplicado durante os esforços de ciclagem.

O objetivo deste trabalho é estudar o comportamento cíclico de três tipos de solos reforçados com uma geogrelha de poliéster, buscando-se quantificar influências tais como o tipo de solo, a tensão normal e o nível de esforço cisalhante aplicado durante os ensaios cíclicos. Para essa finalidade, o equipamento de ensaios cíclicos do Laboratório de Geossintéticos da Escola de Engenharia de São Carlos - EESC-USP foi modificado buscando um melhor controle sobre diversas variáveis de ensaio, como a amplitude e o tempo dos pulsos de carga e a velocidade de aplicação da força de arrancamento.

Em síntese, este estudo teve como objetivos centrais: 
a) Modificar o equipamento de ensaios cíclicos a fim de conferir precisão de carga de ciclagem e de arrancamento; aumentar a precisão das medições de deslocamentos; instalar equipamentos ou programações de segurança para a utilização do equipamento e aperfeiçoar o sistema de fixação de amostra a fim de evitar escorregamentos dos corpos de prova.

b) Realização de ensaios de arrancamento nos diversos tipos de solos para a obtenção de parâmetros de resistência de cada tipo de sistema solo-reforço ensaiado.

c) Realização de ensaios de arrancamento cíclico em reforços confinados nos solos utilizados nos ensaios de arrancamento, fazendo-se variar as tensões confinantes e forças de arrancamento aplicadas.

\subsection{Organização do Texto}

Com o objetivo de facilitar o entendimento desta dissertação acerca das modificações no equipamento de ensaios cíclicos e dos ensaios cíclicos, o trabalho foi dividido em mais quatro capítulos. O Capítulo 2 elucida aspectos de solo reforçado com geossintéticos, abrangendo os principais aspectos a respeito destes sistemas. O Capítulo 3 apresenta o equipamento de ensaios cíclicos e suas respectivas modificações, os solos e o reforço utilizados. No Capítulo 4 são exibidos os principais resultados dos ensaios de arrancamento e ciclagem realizados com areia, silte e brita, comparando os resultados entre si, e por fim, o Capítulo 5 apresenta as principais conclusões acerca dos resultados obtidos com o equipamento modificado e o comportamento dos diferentes solos com o reforço. 


\section{Revisão da literatura}

A revisão bibliográfica que se segue apresenta aspectos a respeito de solos reforçados, em especial, de sua caracterização obtida a partir de ensaios de arrancamento em condições estáticas e cíclicas de carga.

\subsection{Solo reforçado}

Solo reforçado é a melhoria na qualidade de um solo natural através da aplicação de elementos de reforço como materiais naturais, barras ou fitas metálicas, materiais poliméricos e tecidos. Esta forma de melhoria é prática conhecida a cerca de 3000 A.C., quando se utilizavam estivas de junco, palha e bambus como elemento de reforço (VERTEMATTI, 2004). Estes compostos constituídos de fibras resistentes e solo foram empregados em obras relevantes como a Muralha da China e obras do Império Romano.

O reforço de solo é utilizado principalmente para aumentar a capacidade de carga, diminuir a deformabilidade e aumentar a estabilidade da massa de solo, o que possibilita melhor compactação do mesmo e viabiliza obras de taludes verticais de solo com grandes alturas, obras de fundações sobre solos moles e taludes reforçados, entre outras, fornecendo considerável melhora na capacidade de carga e estabilidade.

Alguns exemplos de utilizações de reforços são na concepção de taludes rodoviários, ferroviários e de acessos de pontes, que utilizam solo do próprio local e necessitam de considerável estabilidade quanto a cargas e deformações. São utilizados também na construção de fundações sobre solos com baixa capacidade de carga como solos orgânicos e encharcados e em base de pavimentações de rodovias, ferrovias e aeroportos. 
O reforço de solo pode ser realizado de diversas maneiras, dependendo do problema em análise e da obra idealizada. Uma das maneiras de reforço se dá através do confinamento do solo em células ou camadas, fornecendo resistência através do próprio confinamento. Pode-se aplicar reforço para fortalecer linhas de ruptura no maciço dissipando a tração do solo no reforço ancorado, e ainda, utiliza-se reforço em base de fundações e pavimentos com a finalidade de redistribuir as tensões verticais da camada de solo ao longo do reforço.

Atualmente a prática de reforço de solos é mais comumente realizada através da utilização de materiais geossintéticos (GUPTA, 2009), buscando fornecer ao maciço um incremento de resistência e redução de sua compressibilidade (PIMENTEL, 2007). Estes reforços também atuam aliviando as tensões no solo, absorvidas pelo reforço que acaba por compatibilizar deformações do maciço com o reforço, e com as outras camadas ou sistemas reforçados circundantes.

Países desenvolvidos utilizam geossintéticos como reforço há mais de 30 anos. Já no Brasil sua utilização é mais notável nos últimos 20 anos e a perspectiva é de crescimento gradual desta tecnologia (ANTUNES, 2008).

\subsubsection{Comportamento de solos sobre ciclagem}

O solo por ser composto de materiais granulares, vazios e fluidos apresenta comportamento mecânico relativamente complexo. Em obras como rodovias, ferrovias e locais sujeitos a atividade sísmica é de grande valia o conhecimento do funcionamento de cada tipo de solo frente à ciclagem das solicitações de trabalho.

O comportamento do solo sobre estas condições de cargas cíclicas é determinado pelo seu módulo de cisalhamento e características de amortecimento (SEED, 1970). A relação tensão-deformação pode ser obtida por meio de diversos ensaios, como os de compressão 
triaxial, de cisalhamento simples ou torcional conduzidos sob várias condições de carregamento, como vibrações forçadas, propagações de ondas ou mesmo por análises de resposta do solo durante terremotos (SEED, 1970).

A necessidade de se conhecer as tensões atuantes no solo, por exemplo, sobre as camadas componentes de um pavimento e as deformações correspondentes, analogamente a qualquer análise tensão-deformação, necessita adotar comportamentos tensão-deformação para os materiais de interesse. Comumente, empregam-se modelos elásticos, lineares ou não. No caso específico de pavimentos, as diversas camadas componentes estão sujeitas a carregamentos repetidos de variadas intensidades e frequências que originam tanto deformações plásticas, irreversíveis e deformações elásticas, reversíveis ou recuperáveis.

Um material homogêneo, isotrópico e elástico linear tem seu comportamento retratado por meio de dois parâmetros, o módulo de elasticidade $(E)$ e o coeficiente de Poisson. Na condição de carregamento repetido, surgem deformações recuperáveis que traduzem a resiliência do material. A resiliência é uma propriedade que certos materiais apresentam de acumular energia quando carregados aquém das tensões correspondentes à ruptura, retornando à sua condição original e dissipando a energia acumulada uma vez retirada a carga que originou aquela deformação. A medida dessa propriedade é feita, usualmente, por meio do módulo de resiliência $(M r)$, que é um módulo análogo ao módulo de elasticidade do solo, e que traduz a relação entre a tensão aplicada e a deformação resiliênte ou recuperável. A Figura 2.1 a seguir ilustra as duas definições. 


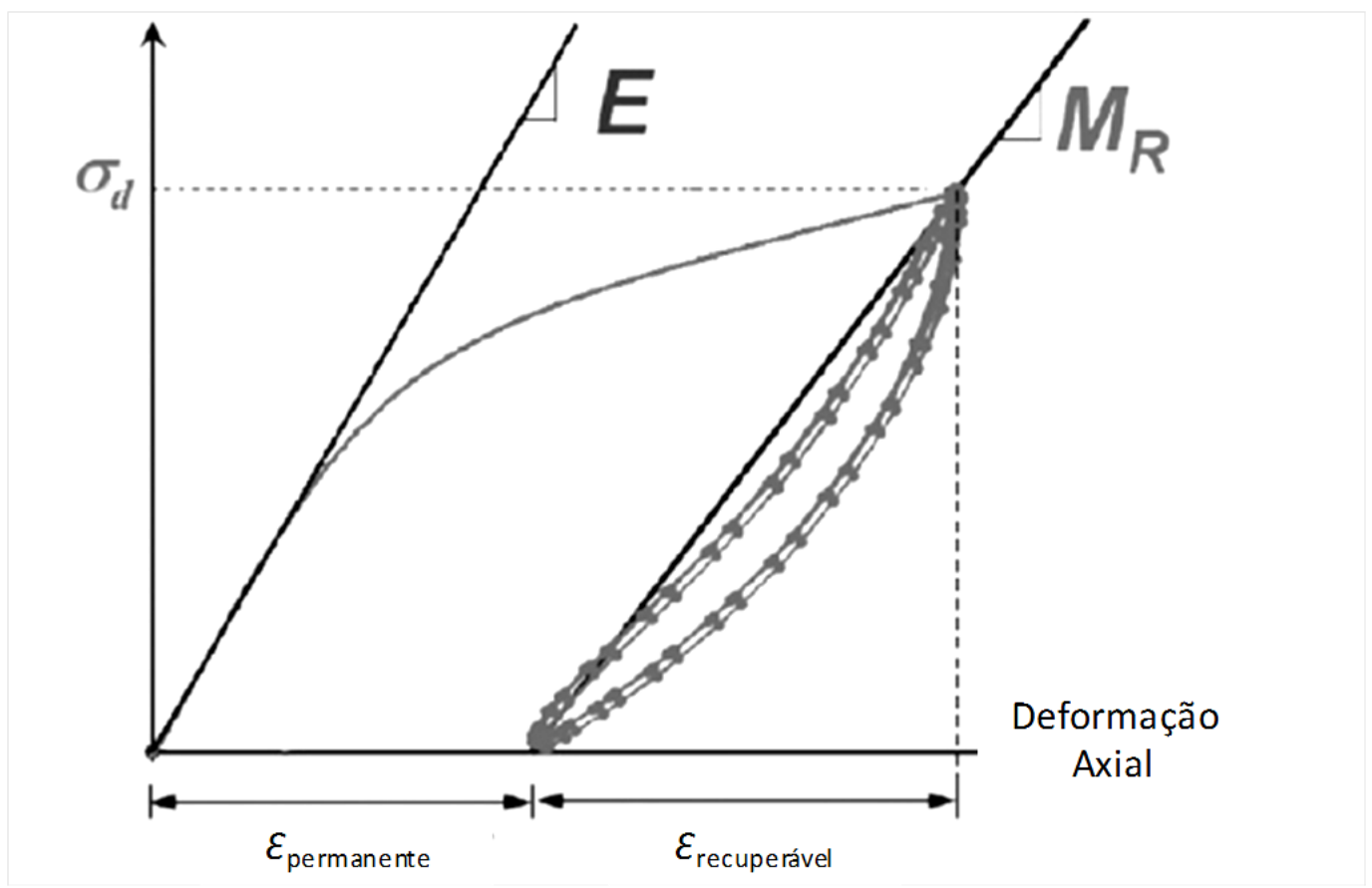

Figura 2.1 - Curvas tensão-deformação e determinação do módulo de elasticidade (E) e resiliente (Mr).

$\mathrm{Na}$ determinação experimental dessa propriedade empregam-se diferentes tipos de ensaios, sendo o de compressão triaxial de carga repetida um dos mais utilizados. Neste caso, define-se o módulo resiliente $(M r)$ como a relação entre a diferença de tensões principais $\left(\sigma_{1^{-}}\right.$ $\left.\sigma_{3}\right)$ aplicada e a deformação resiliente.

Segundo a norma técnica DNER-ME 131 (1994), o Módulo de Resiliencia (Mr) é definido como:

“a relação entre a tensão-desvio $\left(\sigma_{d}\right)$, aplicada repetidamente em uma amostra de solo e a correspondente deformação específica vertical recuperável ou resiliente $\left(\varepsilon_{R}\right)$..”

Assim, o Módulo de Resiliencia (Mr) é definido pela Equação 2.1 a seguir:

$$
M_{r}=\frac{\sigma_{d}}{\varepsilon_{r}}
$$

onde, 


$$
\varepsilon_{r}=\frac{\Delta_{h}}{H_{0}}
$$

Onde: $\Delta h=$ Deformação resiliente, $H_{0}=$ distância inicial, $\sigma_{d}=$ tensão desvio aplicada repetidamente e $\mathcal{E}_{r}$ é a deformação específica resiliente.

Quando se utiliza de ensaios como o triaxial cíclico para obtenção deste módulo, os solos são submetidos a condições de trabalho semelhantes às que ocorrem nos pavimentos devido ao tráfego (MARMITT et al., 2010). O equipamento triaxial de cargas repetidas utilizado por Marmitt et al. (2010) para a ciclagem de britas é ilustrado na Figura 2.2 a seguir.
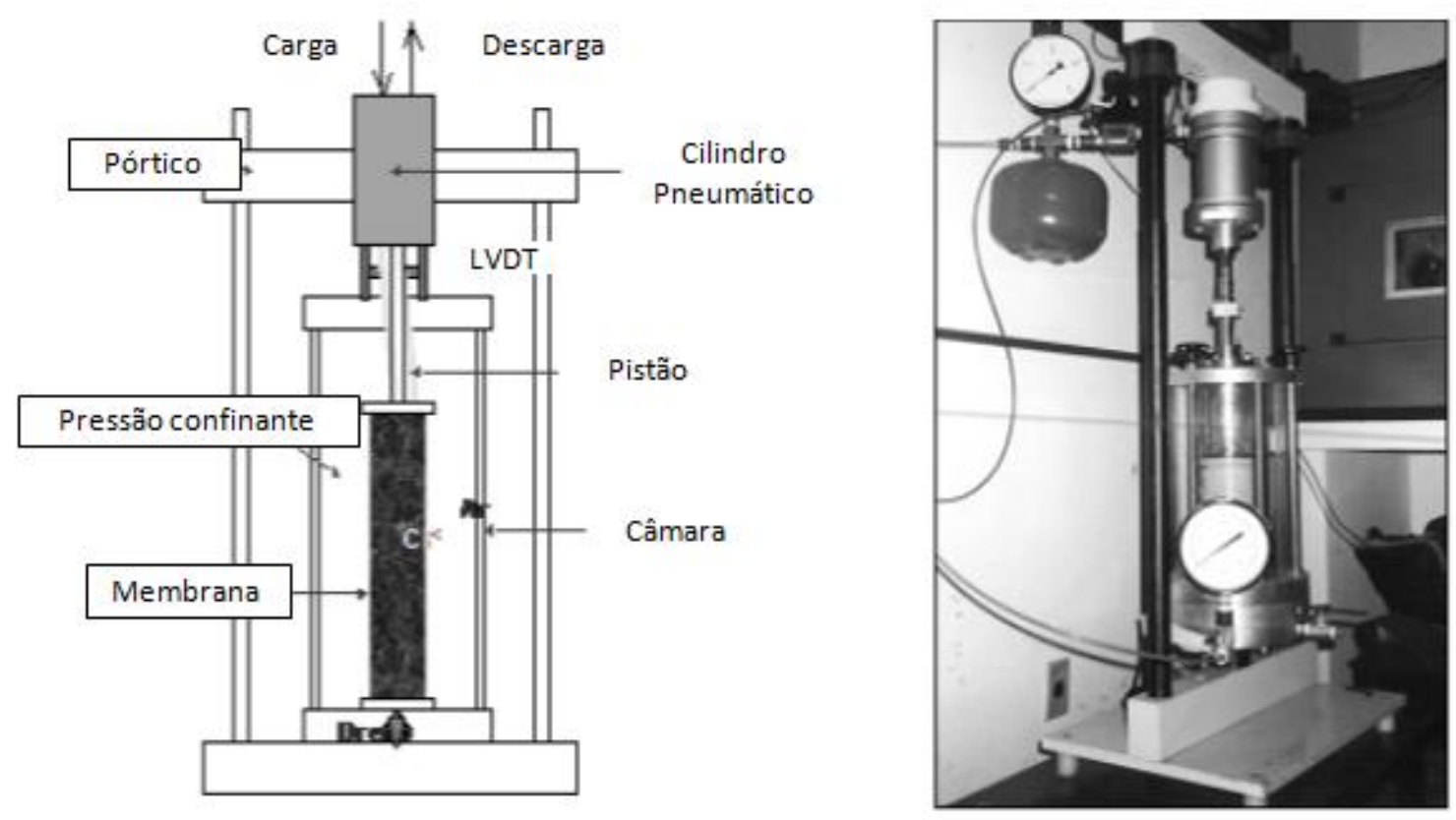

Figura 2.2 - Equipamento triaxial cíclico (Adaptado de MARMITT et al., 2010).

Para se representar um comportamento resiliente único de qualquer tipo de solo ou material não tratado quimicamente pode-se utilizar o modelo composto, que representa o $\mathrm{Mr}$ em função de todas as tensões aplicadas, expresso na Equação 2.3 a seguir (Takeda, 2006). 


$$
M_{r}=K_{1} * \sigma_{d}^{K_{2}} \sigma_{3}^{K_{3}}
$$

Como a maioria dos solos apresenta a relação tensão-deformação curvilínea como mostrado na Figura 2.3 a seguir, o módulo de cisalhamento é normalmente expresso pelo módulo secante, que é determinado pelos pontos extremos do ciclo de histerese do solo, enquanto o fator de amortecimento é proporcional à área interna do ciclo de histerese. Devese ressaltar que cada propriedade em relação ao modulo de cisalhamento e ao amortecimento do solo dependerá da magnitude de deformações a que cada corpo de prova é submetido, como ilustrado na Figura 2.3 a seguir, onde $G_{1}$ e $G_{2}$ são os módulos de cisalhamento, $Y_{1}$ e $Y_{2}$ são os níveis de deformação.

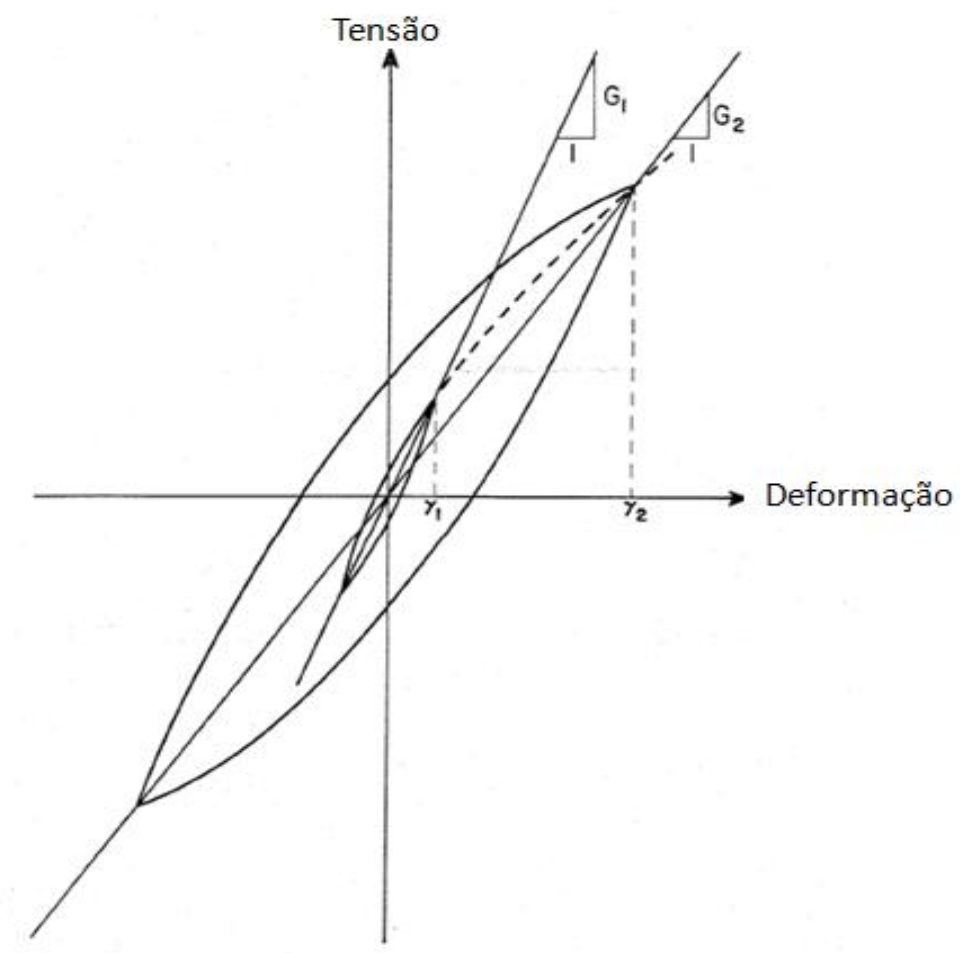

Figura 2.3 - Relações tensão-deformação de histerese a diferentes magnitudes de deformação (Adaptado de SEED, 1970).

O comportamento tensão-deformação de solos apresenta uma relação não linear. Sob baixas deformações o solo apresenta baixa deformabilidade, e com o aumento gradual das 
deformações ocorre aumento expressivo de deformabilidade, como ilustrado na Figura 2.4 a seguir, onde $E_{0}$ é o valor máximo do módulo, $E_{s}$ é o módulo secante, $E_{t}$ é o tangente, $\varepsilon_{0}$ é a deformação e $\sigma$ a tensão confinante (ATKINSON, 2000).

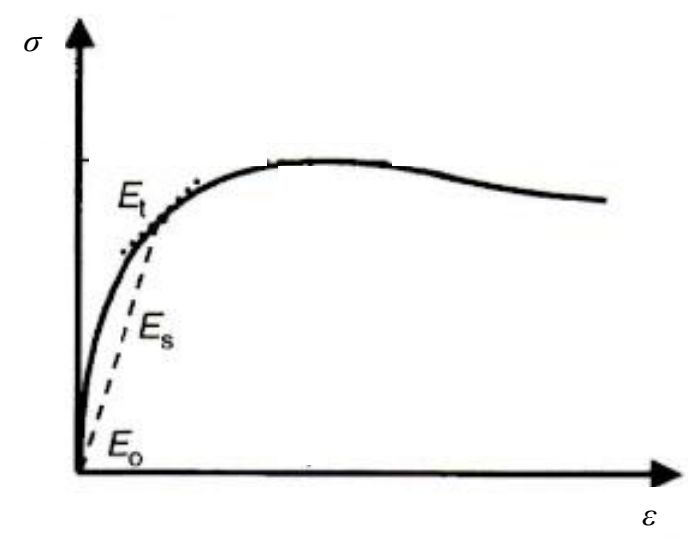

(a)

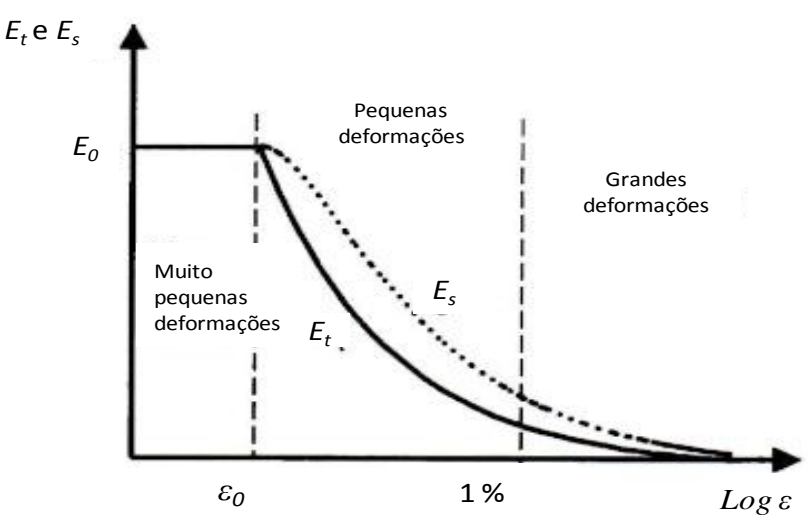

(b)

Figura 2.4 - Relação não linear entre (a) tensão e deformação e (b) degradação do módulo de elasticidade com o aumento da deformação (Modificado de ATKINSON, 2000).

Além de Marmitt et al. (2010), Ling (2008) realizou ensaios de cisalhamento cíclico lento (um ciclo demorava alguns minutos), e constatou que a resistência na interface sologeogrelha não foi afetada significativamente pelo carregamento cíclico. Perkins (2004) também utilizou ensaios triaxiais cíclicos para obter a resiliência de solos granulares, porém, não encontrou diferenças de modulo de resiliência entre agregados reforçados e agregados sem reforço, sendo mais notável o efeito do reforço quanto à redução de deformações permanentes.

Pesquisas internacionais como a normatização recomendada por NCHRP (2004) buscam padronizações a respeito do ensaio que determina módulo de resiliência de materiais granulares de base, sub-base e solos de subleito. 
Quanto à ciclagem do material granular a ser realizada em ensaios triaxiais cíclicos, o corpo de prova fica sujeito às cargas de contato e a sobrecarga cíclica, conforme Equação 2.4 a seguir:

$$
P_{\text {máx }}=P_{\text {contato }}+P_{\text {cíclico }}
$$

As cargas de contato são carregamentos verticais colocados sobre o corpo de prova com o objetivo de manter um contato positivo entre o aplicador de sobrecarga e a tampa superior do corpo de prova. As cargas de contato incluem ainda o peso da tampa superior e a carga estática aplicada pelo pressionador do sistema de carregamento. Já as cargas cíclicas são definidas como carregamento repetitivo aplicado ao corpo de prova (NCHRP, 2004), como pode ser observado na Figura 2.5 a seguir.

Em NCHRP (2004) são expressos parâmetros de comportamento da ciclagem, assim como o tratamento dos dados de resiliência.

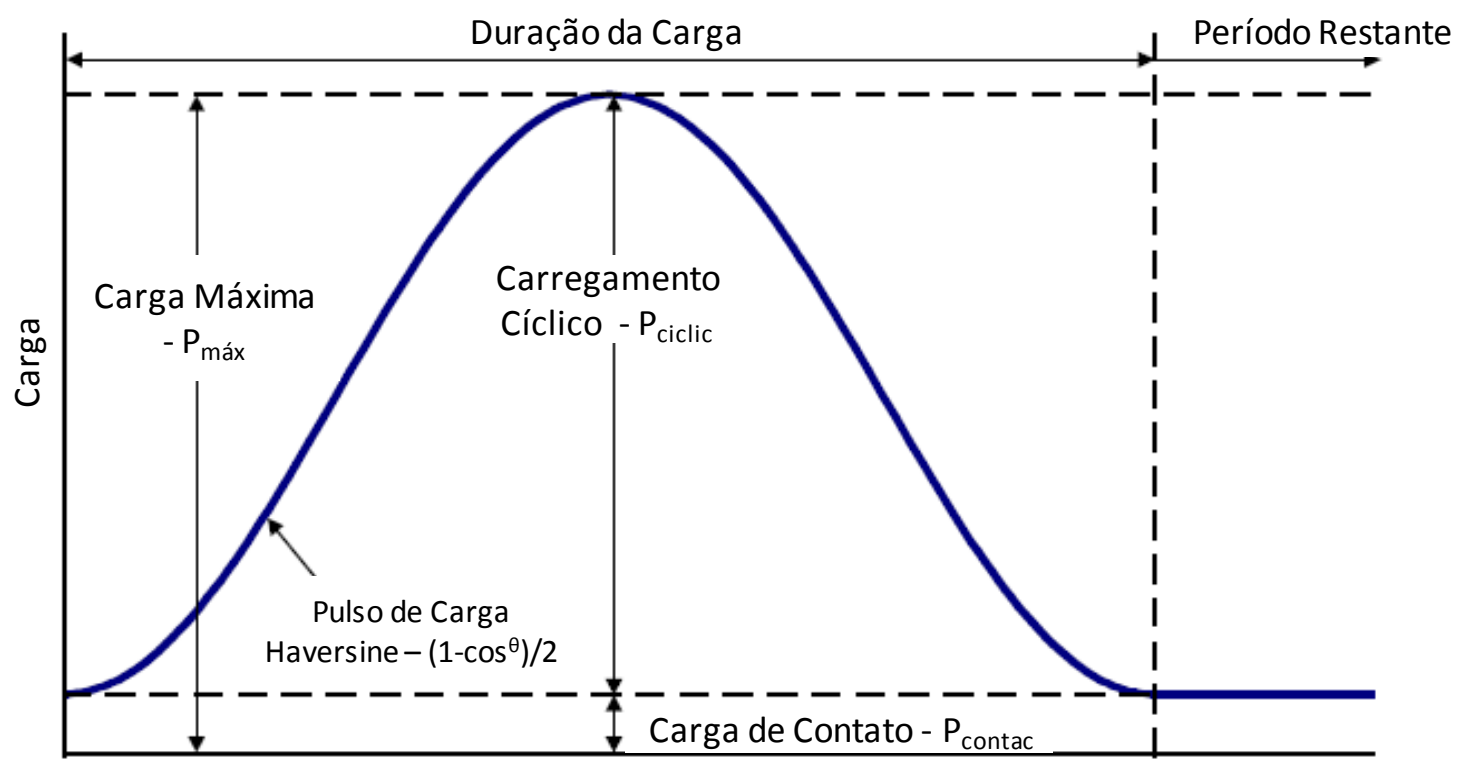

Tempo

Figura 2.5 - Definições de termos de módulo de Resiliencia (Adaptado de NCHRP, 2004). 
Baseado em pesquisas como as de Marmitt et al. (2010) pode-se melhorar o emprego de materiais no pavimento conhecendo-se características como valores de $M r$. A ciclagem de materiais granulares mostrou que quanto maior for o valor de $\mathrm{Mr}$ maior a resistência do material quanto à ciclagem de cargas impostas pelo tráfego de veículos, e menor é o aparecimento de trincas por fadiga da capa asfáltica acima deste material granular. Estudos anteriores (MENDOZA, 2003) mostram o comportamento do solo quando sujeito a ensaio triaxial cíclico, acumulando deslocamentos através da deformação plástica ao longo das ciclagens, como ilustrado na Figura 2.6 a seguir.

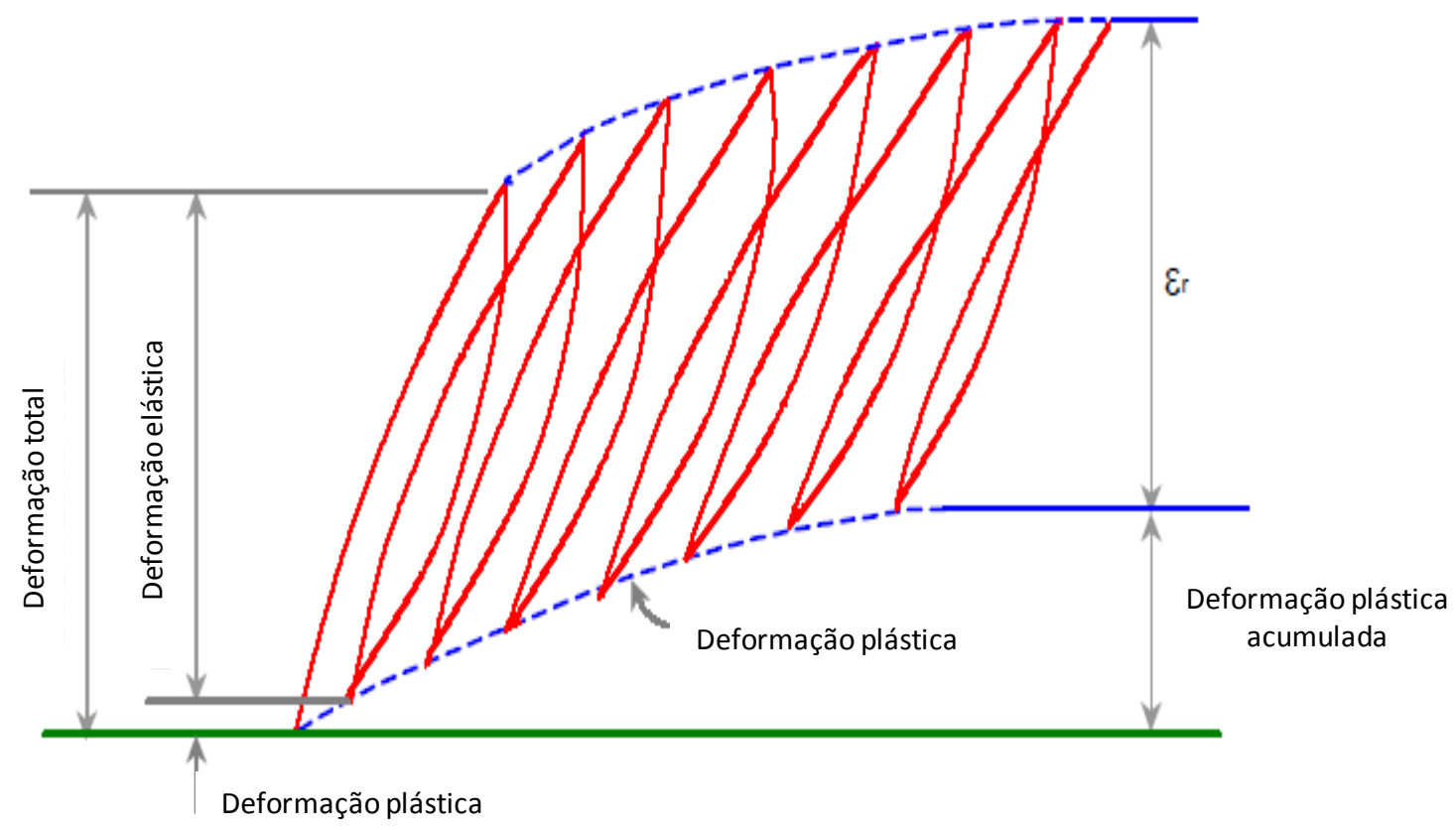

Figura 2.6 - Deformações a cargas baixas repetidas (MENDOZA, 2003).

O comportamento resiliente em solos granulares é caracterizado pelas grandes deformações que ocorrem durante os primeiros ciclos de carga, como consequência do deslocamento relativo entre as partículas. Conforme a ciclagem continua o material adquire rigidez e as deformações permanentes acumuladas ao final de cada ciclo diminuem até tornarem-se muito pequenas ou quase nulas, apresentando arranjo estável de partículas e 
comportamento quase elástico, onde as deformações causadas pela ciclagem são recuperáveis (DNER, 1996).

Para solos finos coesivos, o comportamento é de deformações resilientes que diminuem com o número de repetições de cargas, produzindo um efeito de enrijecimento que pode ser atribuído a um acréscimo do peso específico devido ao carregamento repetido e a um provável rearranjo estrutural das partículas (DNER, 1996).

\subsection{Geossintéticos}

Baseado na norma ABNT NBR 12553 (2003) a definição de geossintéticos é:

"Geossintéticos: Denominação genérica de produtos poliméricos (sintéticos ou naturais), industrializados, desenvolvidos para utilização em obras geotécnicas, desempenhando uma ou mais funções...".

Tal definição de assemelha à dada pela norma ASTM D 4439 (2002) exceto que a definição da ASTM D 4439 (2002) caracteriza o material geossintético como material planar, que compõe parte integral de um projeto, estrutura ou sistema.

Baseado nas definições citadas considera-se que geossintéticos são produtos industrializados provenientes fundamentalmente de polímeros ou fibras naturais manufaturadas. O nome prefixo "Geo" provém de terra e a terminação "sintético" faz referência ao material sintético utilizado na concepção do mesmo. As principais utilizações para os geossintéticos segundo Vertematti (2004), ABNT NBR 12553 (2003) e Koerner (2005) são como reforço, separação, filtração, impermeabilização, estabilização de encostas ou solos, drenagem e confinamento de materiais, sendo os principais tipos de geossintéticos os geotêxteis, as geogrelhas, as geomembranas, as geocélulas as georredes, os geocompostos, entre outros em constante desenvolvimento. Vale ressaltar que os geocompostos são gerados 
através da superposição de mais de um geossintético, geralmente destinado a funções específicas como para reforço ou para drenagem, combinando as funções dos materiais associados.

Os polímeros mais utilizados na fabricação de geossintéticos são o poliéster (PET), polietileno de alta (PEAD) e baixa (PEBD) densidade, polipropileno (PP), policloreto de vinila (PVC) e fibra de vidro (FV). Além da estabilidade estrutural destes polímeros relativamente inertes, ocorre ainda a combinação destes materiais com substâncias como negro-de-fumo que melhora sua resistência à oxidação e à radiação solar, tornando-os mais resistentes à ação de intempéries quando expostos. Diferentemente dos materiais naturais utilizados como reforço (fibras e bambus), a utilização de polímeros evita a decomposição do mesmo, conferindo grande estabilidade ao longo da vida útil da obra.

Como o objetivo desta pesquisa é referente a reforços, os materiais geossintéticos utilizados para este fim são os geotêxteis e as geogrelhas, descritos a seguir, com um enfoque nas geogrelhas, que são materiais mais indicados para reforço de base de pavimentos e outras funções mais sujeitas à ciclagem de carregamentos, devido à sua geometria vazada que permite o contato do material confinante por entre suas aberturas.

\subsubsection{Geotêxtil (GT)}

Os geotêxteis são materiais bidimensionais, permeáveis que se apresentam como estruturas tecidas (GTW), não tecidas (GTN) ou tricotadas, composto por fibras cortadas, filamentos contínuos, monofilamentos, laminetes ou fios (VERTEMATTI, 2004). Suas propriedades mecânicas e hidráulicas permitem que desempenhe várias funções como separação, proteção, filtração, drenagem e reforço em uma obra geotécnica. 


\subsubsection{Geotêxtil Tecido (GTW)}

Caracteriza-se por ser um produto oriundo do entrelaçamento de fios, monofilamentos, ou laminetes (fitas), seguindo direções preferenciais denominadas trama (sentido transversal) e urdume (sentido longitudinal), segundo Vertematti (2004).

\subsubsection{Geotêxtil Não Tecido (GTN)}

Baseado em Vertematti (2004) geotêxtil não tecido é um produto composto por fibras cortadas ou filamentos contínuos, distribuídos aleatoriamente, os quais são interligados por processos mecânicos, térmicos ou químicos.

\subsubsection{Geogrelha (GG)}

É um tipo de geossintético com estrutura em forma de grelha com função predominante de reforço (VERTEMATTI, 2004). Sua estrutura permite a interação do meio em que estão confinadas por entre os elementos de urdume, na direção longitudinal e trama, na direção transversal que a compõe. A Figura 2.7 a seguir ilustra os elementos componentes de uma geogrelha.

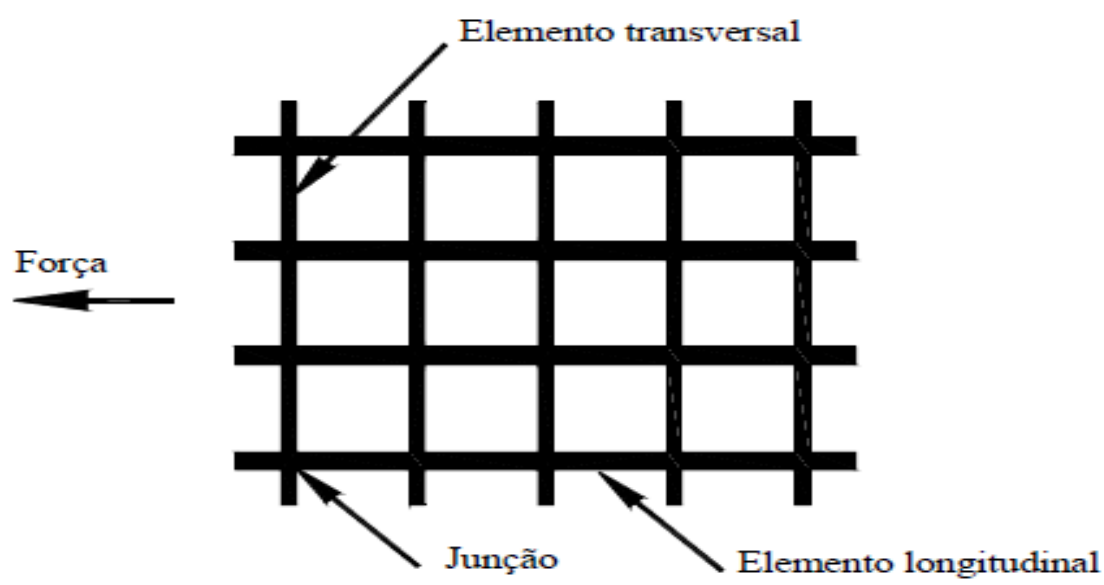

Figura 2.7 - Elementos constituintes de uma geogrelha (KAKUDA, 2005). 
Este material é constituído por elementos resistentes à tração, pode ser considerado unidirecional quando apresenta elevada resistência à tração apenas em uma direção, e bidirecional quando apresenta elevada resistência à tração nas duas direções principais (ortogonais). As geogrelhas podem ser extrudadas, soldadas ou tecidas, dependendo do processo de fabricação.

Quanto à composição das geogrelhas, as mais comuns são as de polietileno de alta densidade (PEAD), poliéster (PET), polivinil clorado (PVC), polipropileno (PP), poliamida ou náilon (PA), fibra de vidro (FV), entre outros.

\subsubsection{Comportamento dos geossintéticos}

De acordo com Perkins (2000) os materiais geossintéticos são conhecidos por apresentarem comportamento termo-visco-elasto-plástico, dependente da direção e ainda em alguns casos a tensão depende do comportamento do polímero.

O comportamento de tensão-deformação-elasto-plástico apresenta resposta não linear durante o carregamento como ilustrado esquematicamente na Figura 2.8(a) a seguir. $\mathrm{O}$ comportamento termo-viscoso é apresentado na Figura 2.8(b), e mostra que diminuindo-se a temperatura ou aumentado-se a taxa de carregamento se obtém uma tensão-deformação mais rígida. O comportamento anisotrópico ou comportamento dependente da direção implica em uma diferente resposta de tensão deformação dependente da direção que o carregamento é aplicado, como na Figura 2.8(c).

O comportamento observado na Figura 2.8(d) ocorre quando é aplicado um tensionamento cíclico com amplitude constante, resultante do conceito de endurecimento cinemático que permite a região elástica expandir, contrair e modificar com carregamento e 
descarregamento sofrido pela amostra, representando o acúmulo de deformações permanentes devido ao ciclo de carregamento aplicado.
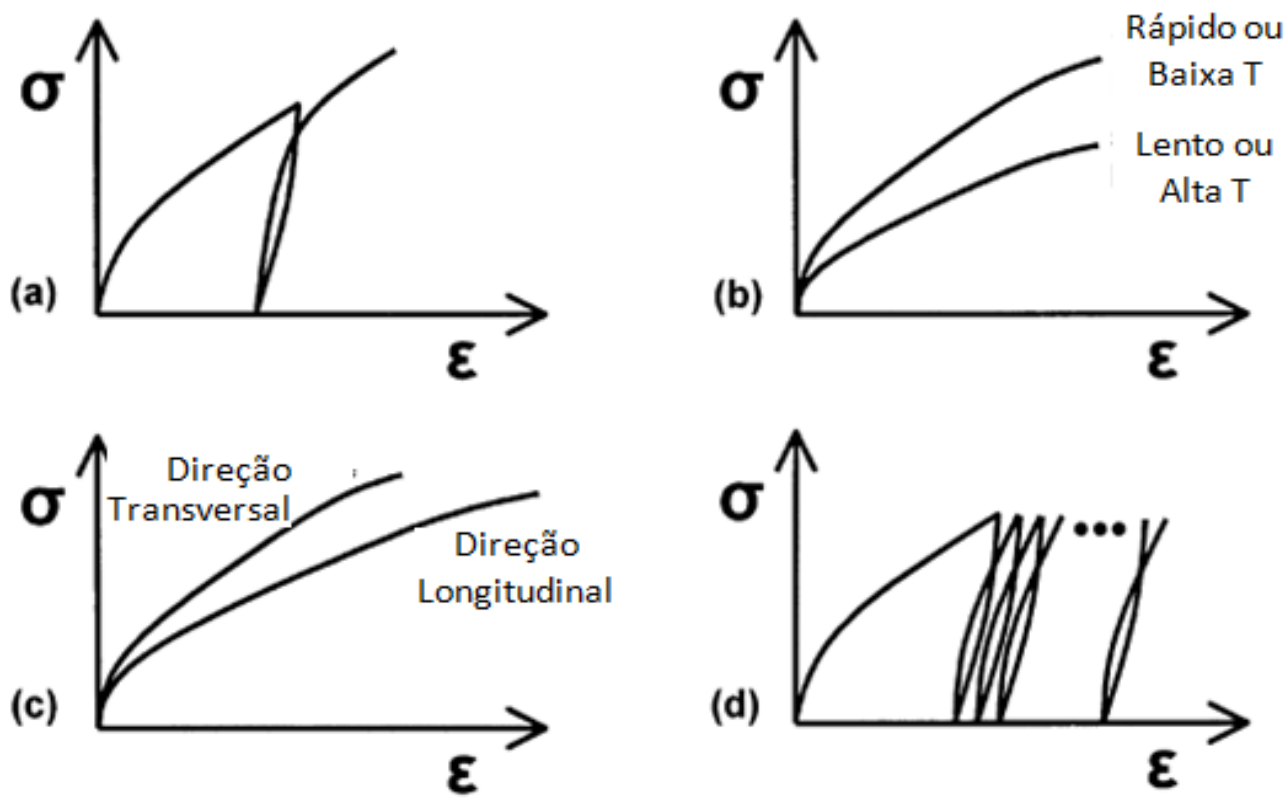

Figura 2.8 - Comportamento termo-visco-elasto-plástico onde (a) Elasto-Plástico, (b) Termo-Viscoso, (c) Anisitrópico, (d) Comportamento cíclico Tensão-Deformação (Adaptado de PERKINS, 2000).

\subsection{Reforço de pavimentos}

A função de reforço de geossintéticos é a de aumentar a capacidade estrutural ou capacidade de carga de um sistema pela transferência do carregamento para o material geossintético (GUPTA, 2009). Quando utilizado para fins de separação o geossintético previne o solo do subleito de penetrar na camada de agregado da base e sub-base, pois o potencial de mistura das camadas do solo é maior quando o material de base é compactado sobre o subleito e ainda durante a operação do tráfego.

O geossintético fornece ainda a função de filtração, restringindo o movimento das partículas e assim aumentando a vida útil da estrutura. O mesmo permite ainda a drenagem 
através do plano do material através da transmissividade, permitindo o movimento lateral da água (GUPTA, 2009).

Além destas funções dos geossintéticos, o reforço com o mesmo pode desempenhar funções secundárias como mitigação de propagação de fraturas ou fissuras pelo selamento da camada de asfalto quando usado na sobreposição do pavimento (GUPTA, 2009).

É amplo e ainda crescente o emprego de geossintéticos em reforços de pavimentações, onde podem ser utilizadas geogrelhas (GARCÍA, 2011), geotêxteis (ZAMBRANO, 2007) e ainda geocompostos (KOERNER, 2005), que viabilizam física e economicamente a construção de rodovias sobre solos moles, utilizando estes materiais geossintéticos para reforço de base de pavimentos e capa asfáltica (ZAMBRANO, 2007; CARMO, 2011), como exemplificado na Figura 2.9 a seguir.

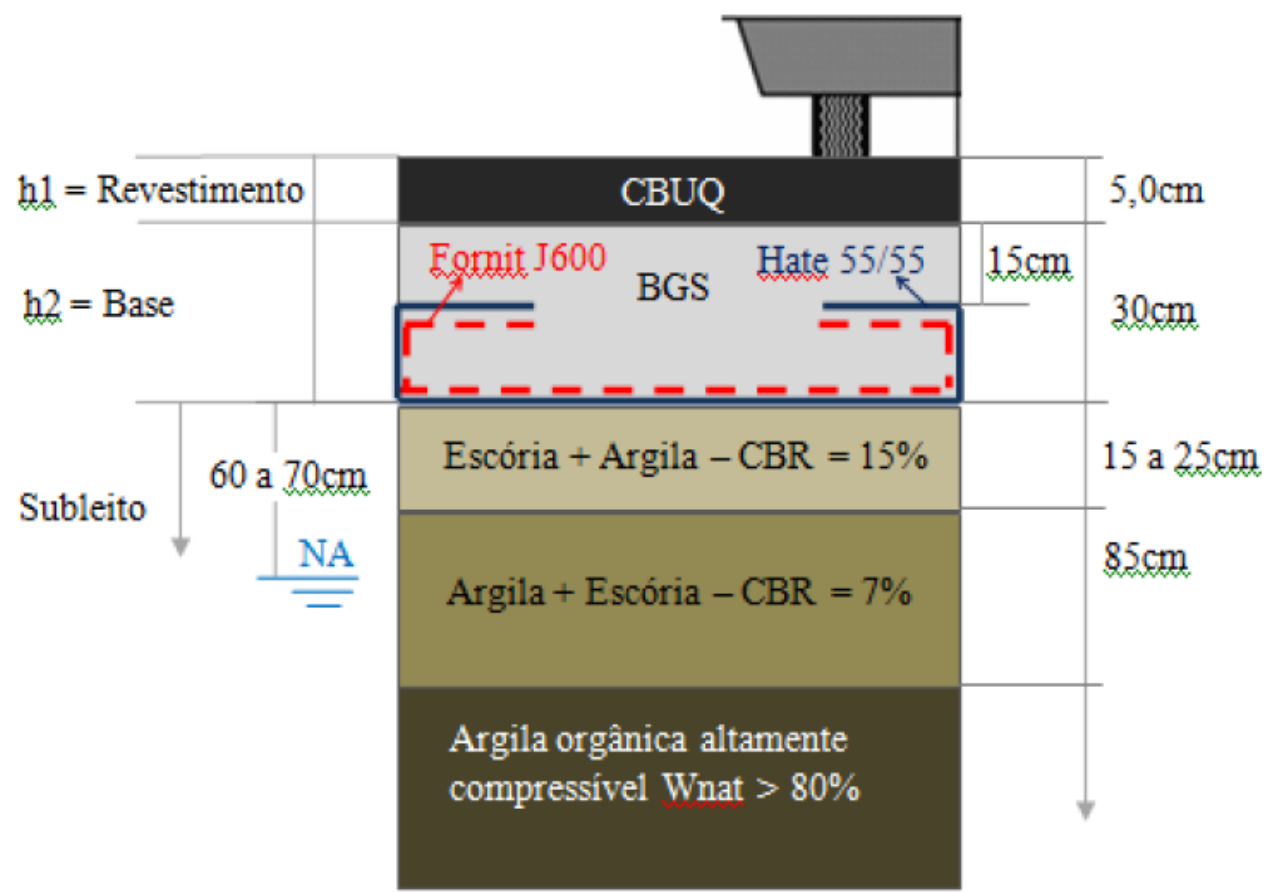

Figura 2.9 - Seção de pavimento betuminoso. $C B \cup Q=$ Concreto betuminoso usinado a quente; BGS = Brita graduada simples; Fornit = Geogrelha específica utilizada; Hate = Geotêxtil tecido específico utilizado (CARMO, 2011). 
Os geossintéticos utilizados em reforço de pavimentações apresentam elevada rigidez a baixas deformações (ZAMBRANO, 2007; CARMO, 2011), devido à compatibilização das deformações do reforço com o pavimento.

Alguns pontos críticos acerca do dimensionamento dos pavimentos são apontados em (GUPTA, 2009), que se baseia nos princípios de que pavimentos flexíveis são construídos de modo que as cargas de tráfego são distribuídas a partir da superfície de contato para as camadas subjacentes, devido à flexão do pavimento. Disto resulta uma distribuição cônica de tensões que espalha o carregamento sobre uma área maior do que a área de contato real dos pneus, dissipando as tensões ao longo da profundidade, como se ilustra na Figura 2.10 a seguir.

Considerando esta dissipação de tensões, o projeto de pavimentos é verificado para dois pontos críticos com relação à deformação. $\mathrm{O}$ primeiro considera a deformação de tração horizontal que ocorre na base da camada asfáltica e topo do subleito, que é utilizada como parâmetro de projeto para prevenir a quebra por fadiga devido ao repetido carregamento do tráfego. $\mathrm{O}$ outro ponto crítico de deformações é referente às deformações permanentes no subleito, onde as tensões verticais atuantes sobre ele são um importante fator de projeto, buscando prevenir o acúmulo de deformações durante a vida de serviços do pavimento. Uma das funções do pavimento é reduzir a tensão vertical nesta camada, para que não ocorram estas deformações prejudiciais no pavimento.

A tensão vertical admissível num dado subleito depende da resistência ao cisalhamento e do comportamento tensão-deformação do material que o compõe, que são combinados juntamente na forma de tensão de compressão vertical admissível, que é usado como critério de projeto. 


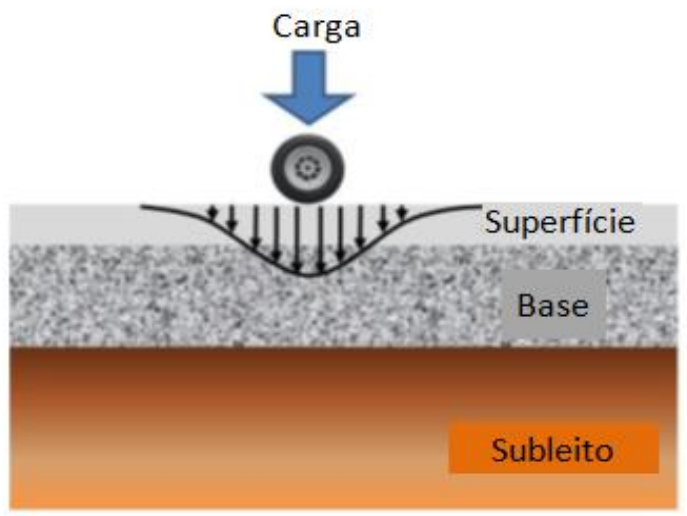

(a)

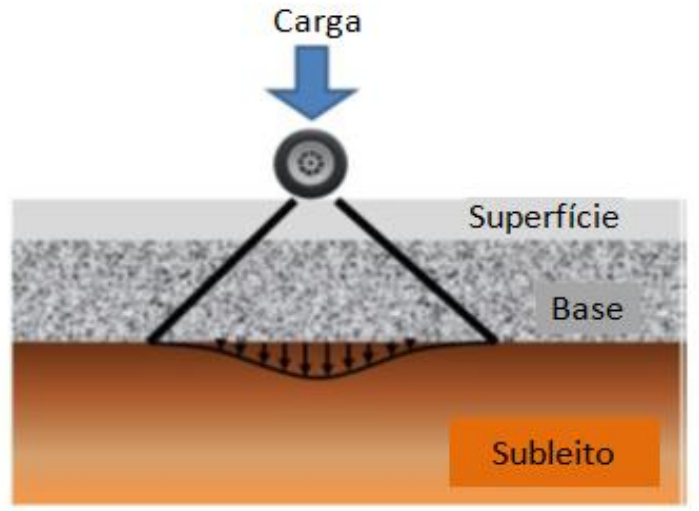

(b)

Figura 2.10 - Distribuições das tensões com camadas em um pavimento flexível (a) área de altas tensões diretamente abaixo do carregamento da roda; (b) redução do carregamento ao nível do subleito (Adaptado de GUPTA, 2009).

Gupta (2009) assinala que o pavimento sofre dois principais tipos de falhas, caracterizadas como estrutural e funcional, sendo que a falha funcional torna o pavimento incapaz de realizar suas funções pretendidas. Já a falha estrutural leva ao colapso do pavimento, tornando-o incapaz de sustentar cargas impostas em sua superfície. Consequentemente a falha estrutural requer uma completa reconstrução do pavimento, enquanto a falha funcional pode ser remediada com uma manutenção regular na via. Estas falhas ocorrem devido a carregamentos de tráfego e condições ambientais, estas representadas pelas variações extremas de temperatura e umidade local. O umedecimento e secagem, congelamento e degelo do pavimento causam fraturas ou quebras nos materiais de base, gerando finos no subleito que levam ao desenvolvimento de fissuras.

São apontadas ainda em Gupta (2009) práticas construtivas que prejudicam o desempenho do pavimento, como a utilização de agregados sujos e fiscalização inadequada, e práticas que ampliam a vida útil do pavimento, como a manutenção através de selagem de fissuras em intervalos de tempos apropriados. Ultimamente a definição de vida útil de um 
pavimento representa a decisão calculada por parte do engenheiro durante o projeto, que balanceia o aumento no custo inicial da construção contra o aumento no custo de manutenção.

O principal objetivo da pesquisa de Gupta (2009) é quantificar os benefícios da utilização de geossintéticos como reforço de pavimentos flexíveis. A distribuição de tensões em nível da camada de subleito para um pavimento flexível não reforçado geralmente é maior do que para um pavimento reforçado com geossintéticos, como ilustrado na Figura 2.11 a seguir. A adição do geossintético como proposta de reforço geralmente envolve sua colocação na interface entre as camadas de base e a sub-base ou na interface entre as camadas de subbase e sub-leito. Isto leva à redistribuição das tensões na camada de subleito, causando redução das deformações verticais e melhora no desempenho do pavimento.

Documentos como USACE (2003) descrevem os três principais mecanismos de reforço de pavimentações que têm sido identificados envolvendo o uso de geogrelhas, que são o confinamento lateral, melhoria na capacidade de suporte e efeito de membrana tensionada.

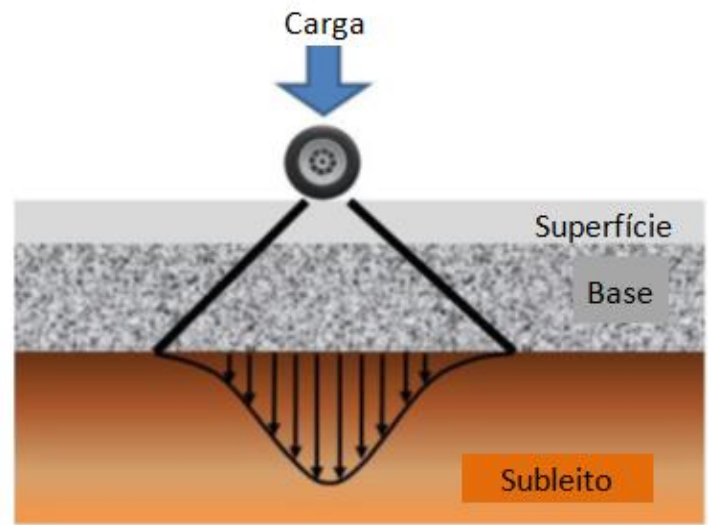

(a)

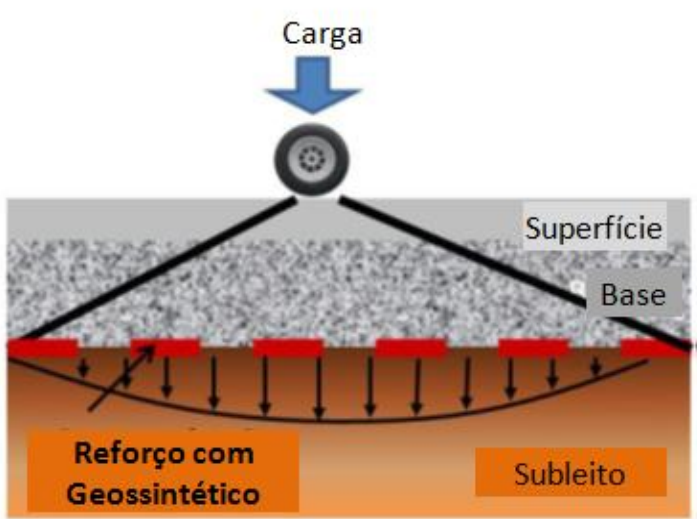

(b)

Figura 2.11 - Magnitudes de cargas relativas no nível da camada de sub-leito para: (a) Pavimento flexível não reforçado e (b) Pavimento flexível reforçado com geossintético (Adaptado de GUPTA, 2009).

O confinamento lateral refere-se ao confinamento do material agregado durante o carregamento, que restringe o fluxo lateral do material abaixo do carregamento. Desde que a 
maioria dos agregados utilizados em sistemas de pavimentos são materiais dependentes da tensão, a melhora do confinamento lateral resulta em um aumento no módulo do material de base. O efeito do aumento do módulo do material de base é uma melhora na distribuição da tensão vertical aplicada ao subleito e uma correspondente redução na deformação vertical no topo do subleito. A Figura 2.12 a seguir mostra o confinamento lateral pelo mecanismo de reforço.

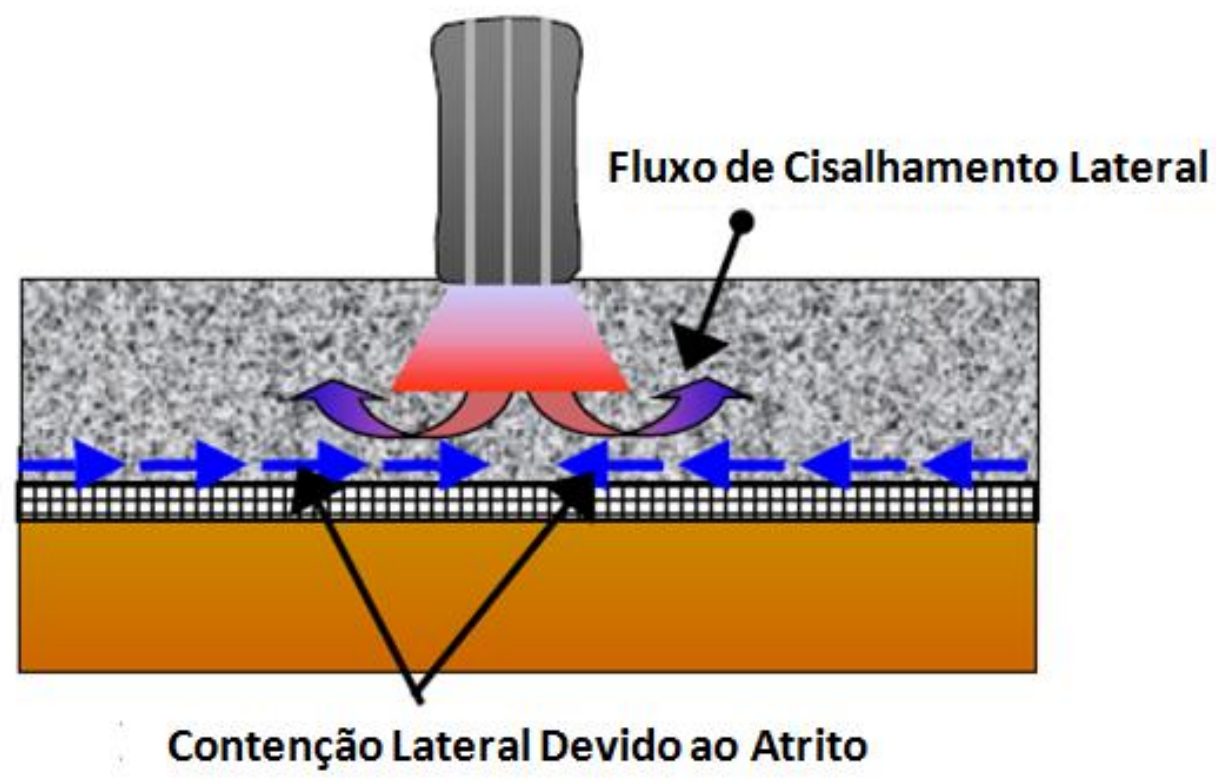

Figura 2.12 - Mecanismo de reforço de confinamento lateral (Adaptado de USACE, 2003).

O segundo mecanismo, de melhora de capacidade de suporte é alcançado pela mudança da superfície de ruptura que se move do subleito, relativamente fraco para o material de base mais resistente. A Figura 2.13 a seguir mostra o conceito da melhora na capacidade de carga. 


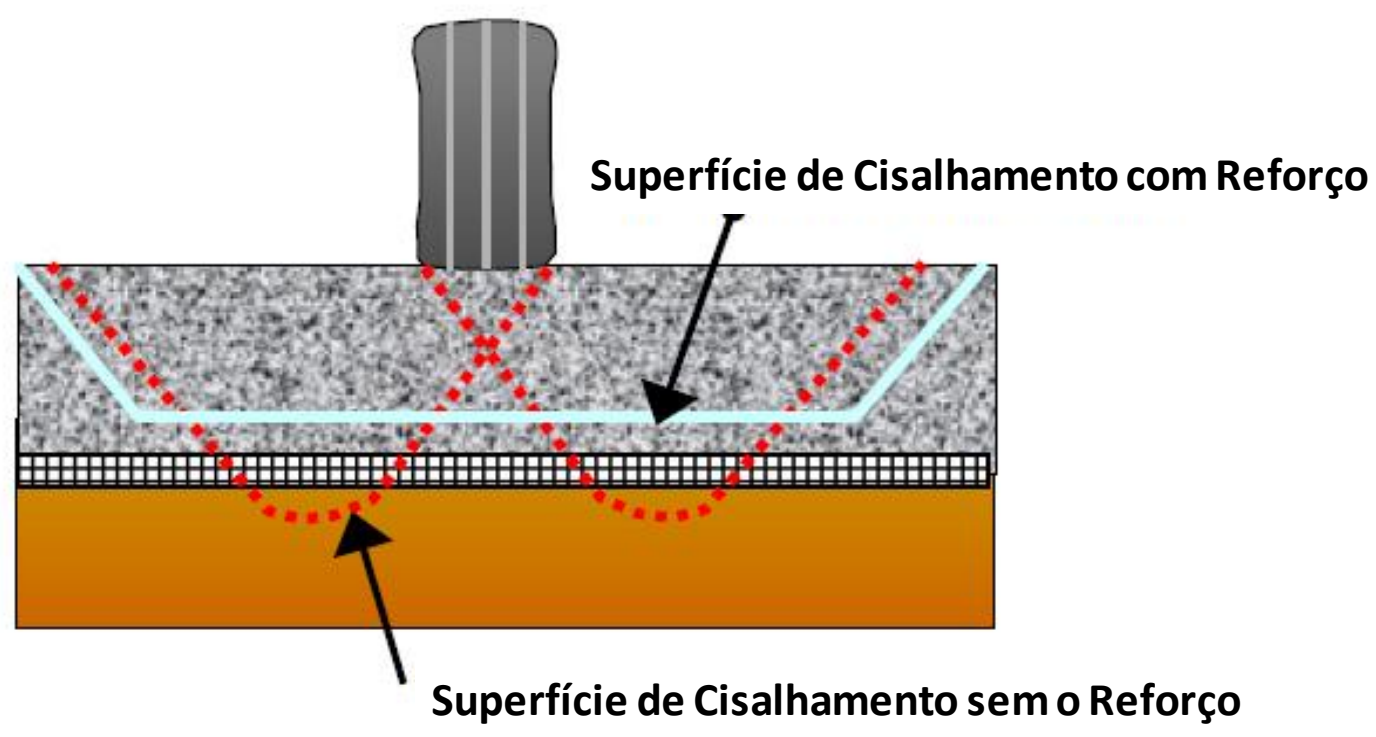

Figura 2.13 - Mecanismo de reforço de melhora de capacidade de carga (Adaptado de USACE, 2003).

O terceiro mecanismo fundamental de reforço foi denominado de "efeito de membrana tracionada". Este efeito é baseado no conceito do incremento de distribuição da tensão vertical resultante da tensão de tração de uma membrana deformada. A Figura 2.14 a seguir mostra o efeito de membrana tensionada.

Nos estágios iniciais da investigação sobre reforço com geogrelhas em sistemas de pavimentos, o efeito de membrana tracionada foi pensado para ser o mecanismo de reforço primário, contudo, investigações subsequentes têm mostrado que os beneficios do reforço são obtidos sem deformação significante da seção do pavimento. Assim, o confinamento lateral tem sido identificado como mecanismo de reforço primário, seguido pelo conceito de aumento na capacidade de carga e o efeito de membrana tracionada. A contribuição de cada um destes mecanismos individuais provenientes do reforço global do sistema do pavimento pode ser quantificada. Baseado em USACE (2003). 


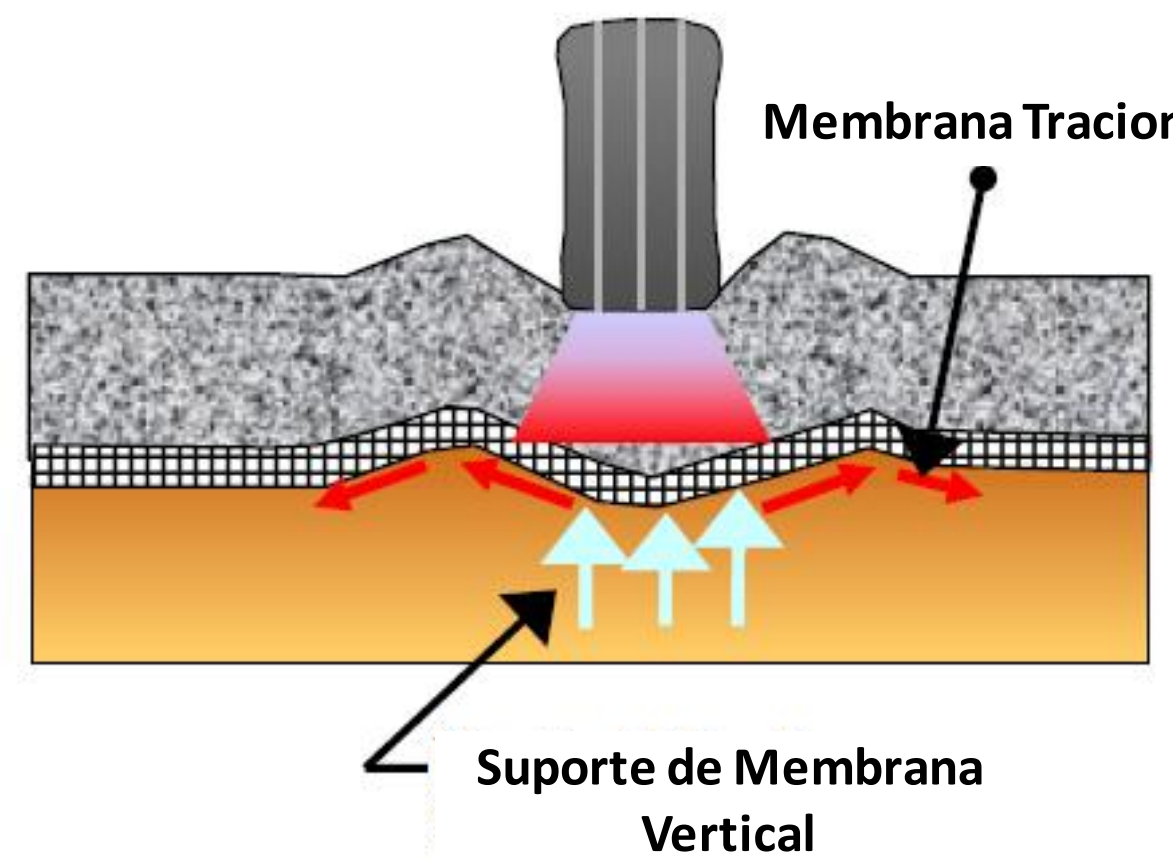

Figura 2.14 - Mecanismo de reforço de efeito de membrana tencionada (Adaptado de USACE, 2003).

Estudos de Perkins (1997 - parte 1) mostram que realmente a melhoria de solos com reforço de camadas de base funciona, e conforme o reforço trabalha no solo sendo tracionado, a melhoria do sistema ocorre proporcionalmente à solicitação do reforço. Antunes (2008), assim como Perkins (1997 - parte 1) também realizou ensaio em placa cíclica sobre brita reforçada sobre solo mole e pode-se notar aumento na vida útil do pavimento.

Palmeira e Antunes (2010) estudaram reforço de base de estradas não pavimentadas reforçadas com geotêxtil e geogrelha, e chegou à conclusão semelhante à de ANTUNES (2008) e PERKINS (1997), de que o reforço aumenta a vida útil do pavimento, e complementa ainda que a geogrelha promove aumento de vida útil maior do que o reforço com geotêxtil.

Na pesquisa de Perkins (2000) é evidenciado que a resposta mecânica de pavimentos reforçados é melhor, apresentando menores deformações em relação à resposta de ciclagem 
do tráfego nos trechos de pavimentação reforçada, e semelhante à Palmeira e Antunes (2010) são obtidas menores deformabilidades com as geogrelhas do que com os geotêxteis. Ainda em Perkins (2000) foi realizado ensaio cíclico com placa metálica sobre leito de solo argiloso reforçado com geogrelha acima da argila e camada de base de 300 a $375 \mathrm{~mm}$ de brita acima da geogrelha, confinando-a. Ensaios sem reforço, com espessuras diferentes, mostraram uma melhor resposta de comportamento tensão-deformação para espessuras maiores, já a inclusão do reforço de geogrelha permitiu a redução da camada de base para $300 \mathrm{~mm}$ apresentando melhores respostas a tensões e deformações do que camada de $375 \mathrm{~mm}$ que não foi reforçada, trazendo economia de espessura da camada de base com a diminuição do material.

Kakuda (2010) utilizou ensaio de ciclagem com placa metálica sobre pavimento apoiado em leito de solo siltoso e mistura solo-brita, avaliando ainda o posicionamento mais favorável do reforço. Foi concluído que a utilização de reforço por meio de geogrelhas mostrou uma diminuição das deformações elásticas e plásticas, e o local que o reforço apresenta maior desempenho foi na interface base-subleito, devido às diferenças de tensões horizontais nas camadas de base e subleito que apresentam solos diferentes. Verificou-se que a inserção da geogrelha é equivalente ao enrijecimento da camada de base.

$\mathrm{Na}$ pesquisa de Leng e Gabr (2002) foram testados dois tipos de geogrelhas semelhantes, uma com resistência nominal de $12 \times 19 \mathrm{kN} / \mathrm{m}$ e outra $19 \times 29 \mathrm{kN} / \mathrm{m}$ na direção transversal e longitudinal, respectivamente. Sob ciclagem, a que apresentou melhor resposta foi a geogrelha mais resistente, permitindo menores deformações plásticas devido ao seu maior módulo de elasticidade em relação à geogrelha de menor resistência. 


\subsection{Interação solo-geossintético}

O entendimento do mecanismo de atuação do geossintético em um solo reforçado é fundamental para a aplicação de métodos de dimensionamento seguros, eficazes e econômicos, porém, o mecanismo de interação solo-geossintético não é tão esclarecido e é comum a utilização de métodos empíricos para o dimensionamento de reforços de pavimentos (ZAMBRANO, 2007).

Muitas tentativas têm sido feitas para interligar o sistema de reforço de pavimentos com geogrelhas com as propriedades geométricas e de engenharia das geogrelhas (USACE, 2003), porém, infelizmente os pesquisadores tiveram pouco sucesso em correlacionar reforço utilizando geogrelhas com propriedades do material individual (USACE, 2003).

É comum na literatura da área a utilização de ensaios de arrancamento visando analisar a interação solo-geossintético (ZAMBRANO, 2007), e pesquisas vêm sendo desenvolvidas para um melhor entendimento deste entrosamento através de ensaios cíclicos no conjunto (GARCÍA, 2011).

A interação solo-geossintético se dá com a penetração de solo nas descontinuidades ou aberturas do mesmo gerando o intertravando do reforço. $\mathrm{O}$ solo que penetra nas aberturas é responsável pelo arraste dos elementos transversais (Figura 2.7 acima), já o restante da ancoragem que atua sobre o material de reforço é proveniente da tensão cisalhante que atua sobre a superfície dos elementos longitudinais e transversais (Figura 2.7 acima), como mostrado na Figura 2.15 e Figura 2.16 a seguir.

Geossintéticos utilizados como reforço são frequentemente solicitados por cargas estáticas provenientes do peso "morto" do solo e adicionalmente pelo carregamento cíclico, 
causado principalmente por carregamentos de tráfego em aterros reforçados de ferrovias e rodovias, encostas íngremes, pontes e pilares reforçados de pontes e proteção de dolinas por geossintéticos (MAYER, 2004).

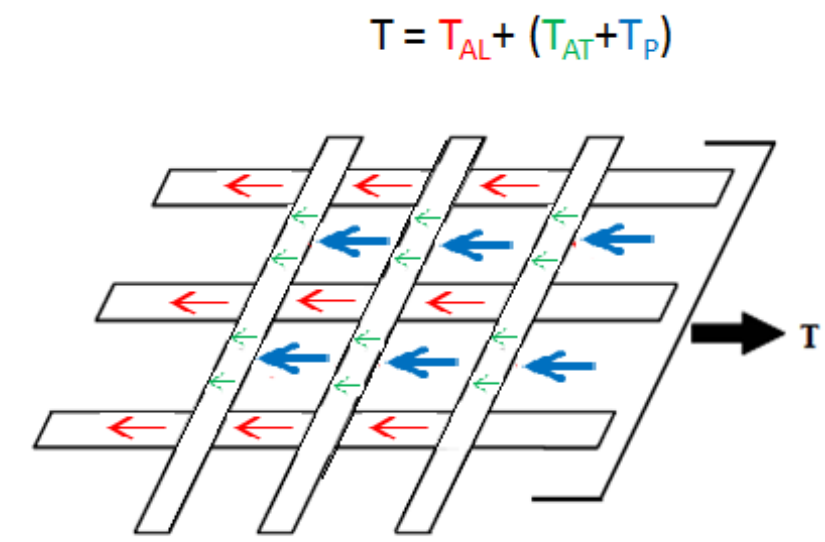

T - Resistência Total do Arrancamento

$\mathrm{T}_{\mathrm{AL}}-$ Resistência de Cisalhamento por atrito no elemento Longitudinal

$\mathrm{T}_{A T}-$ Resistência de Cisalhamento por atrito no elemento Transversal

$\mathrm{T}_{\mathrm{p}}$ - Resistência de Arraste Frontal do elemento Transversal

Figura 2.15 - Ancoragem da geogrelha (Adaptado de KOERNER, 2005).

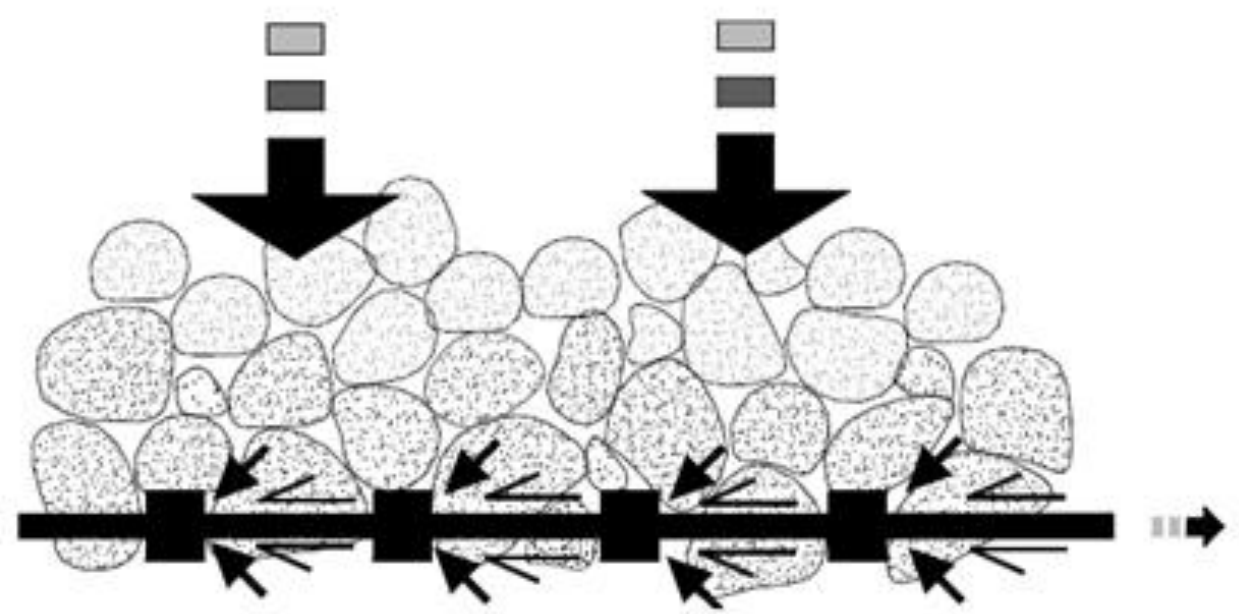

Figura 2.16 - Detalhe de confinamento da região de interface solo-geogrelha (KAKUDA, 2005).

Ocorre ainda a diferença de comportamento de solos que apresentam tamanhos diferentes de partículas, em relação à abertura da geogrelha. O tamanho das aberturas da 
geogrelha e tamanho dos grãos de solo, assim como a espessura do elemento transversal são importantes na determinação à resistência de cisalhamento de interface solo-reforço. Já em relação à geotêxteis, o tamanho das partículas de solo é menos significante (LOPES e LOPES 2000).

O funcionamento destes reforços funciona com a aplicação do carregamento estático $\left(\mathrm{F}_{\mathrm{b}, \text { stat }}\right)$, mais a tensão cíclica vertical $\left(\sigma_{\mathrm{dyn}}\right)$, que induz o carregamento cíclico $\left(\mathrm{F}_{\mathrm{b} \text {,dyn }}\right)$ no geossintético, como ilustrado na Figura 2.17 a seguir.

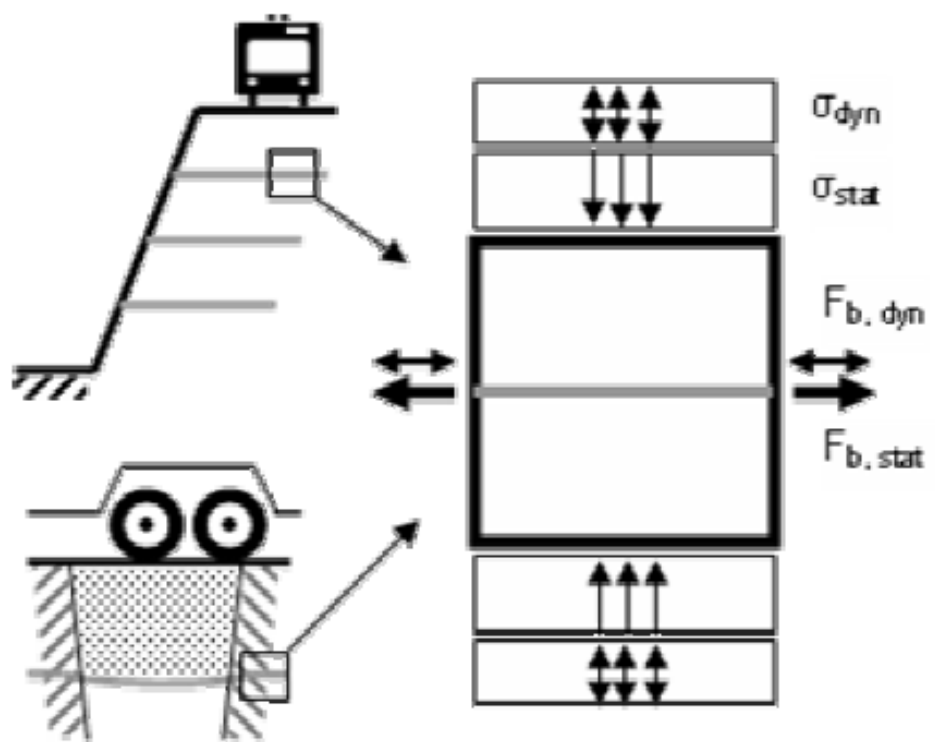

Figura 2.17 - Exemplo de carregamento cíclico em geossintéticos (Aterro íngreme e Dolinas) de Mayer (2004).

Segundo Perkins (2000) ensaios de arrancamento são comumente usados para descrever a resistência ao cisalhamento última de um reforço ao longo de um solo confinante e um geossintético em função de uma força confinante normal. Ensaios de arrancamento podem ainda ser utilizados para definir completamente a relação de interação na interface solo-reforço, entre a tensão cisalhante e a interação deslocamento-cisalhamento. Estes parâmetros de comportamento de reforço e rigidez do sistema são necessários a modelos analíticos utilizados para prever comportamento de estruturas reforçadas com geossintéticos. 


\subsubsection{Ensaios de Arrancamento}

O arrancamento é definido pela (ASTM 7499, 2009) como o movimento do geossintético ao longo de todo o seu comprimento embutido, com o arrancamento inicial ocorrendo quando a parte traseira da amostra se move, e o arrancamento total ocorre quando o movimento é uniforme ao longo do de todo o comprimento embutido, e na parte final do corpo de prova ancorado ocorre deslocamento equivalente a 1/10 do comprimento inicial da amostra no caso de geossintéticos utilizados em reforço.

O ensaio se dá confinando-se a amostra de geossintético em uma caixa de ensaios com uma abertura pela qual parte do material fica para fora da caixa. A parte que fica para fora da caixa é presa a uma garra e é solicitada ao arrancamento, onde são medidas as tensões necessárias ao arrancamento e as deformações.

Este ensaio fornece uma estimativa de como será a interação do material de reforço com o solo ao qual o mesmo está aplicado, quantificando a interação entre os dois. Para a realização deste ensaio pode-se utilizar a norma ASTM D 6706 (Standard Test Method for Measuring Geosynthetic Pullout Resistance in Soil, 2001) que visa mensurar a resistência que o solo oferece quando solicitado o arrancamento do material de reforço. Este ensaio é de suma importância nesta pesquisa, pois fornece parâmetros de ancoragem do material a determinado solo, parâmetro fundamental para a realização da ciclagem sem que ocorra o arrancamento do material.

García (2011) aponta a existência de equipamentos com capacidade de realização de ensaios de arrancamento cíclico que emprega volumes de solo para ensaio de cerca de $0,5 \mathrm{~m}^{3}$ e capacidades de frequências em ciclagens em sua maioria de $0,01 \mathrm{~Hz}$ até $0,5 \mathrm{~Hz}$. O esquema do ensaio de arrancamento segue na Figura 2.18 a seguir. 
Estudos de Cuelho e Perkins (2005) fazem uma interligação dos ensaios de arrancamento cíclico com os ensaios de arrancamento, mostrando que os resultados dos ensaios de arrancamento cíclico tendem a imitar os resultados do ensaio de módulo de resiliência em agregados, mostrando que o módulo de cisalhamento de interface é dependente da tensão, pois aumenta com o aumento da tensão normal e diminui com o aumento da tensão cisalhante.

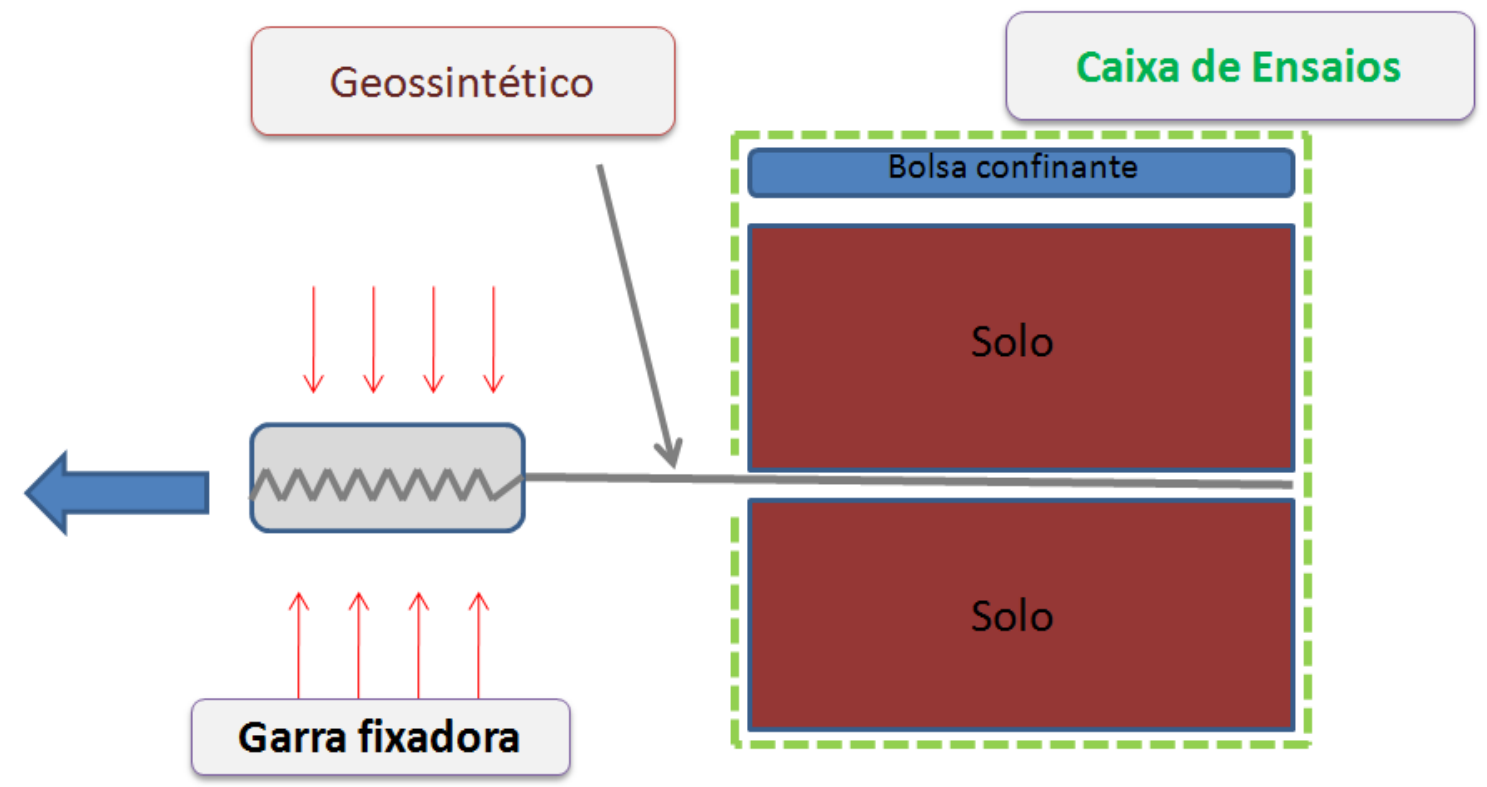

Figura 2.18 - Esquema do ensaio de arrancamento.

Lopes e Ladeira (1996) relatam o comportamento de arrancamento de geogrelhas de PEAD em areia, e afirmam que a variação da compacidade da areia interfere no comportamento do comprimento do corpo de prova, onde, para uma areia fofa, o maior comprimento do corpo de prova aumenta a resistência ao arrancamento, e para uma areia compacta a resistência decresce ligeiramente com o aumento do comprimento da amostra, por causa do aumento do número de vazios. Já a influência da largura da amostra aparenta ser mínima. A aplicação de mangas de $20 \mathrm{~cm}$ diminuiu a resistência ao cisalhamento, pois diminui o efeito de resistência das paredes de entorno. Gupta (2009) também realizou ensaios 
de arrancamento em geogrelha de PEAD e obteve comportamento semelhante ao relatado em outros trabalhos (PERKINS, 2000 e MAYER, 2004) para arrancamento do material, utilizando LVDT's fixados nas posições descritas na Figura 2.19 a seguir.

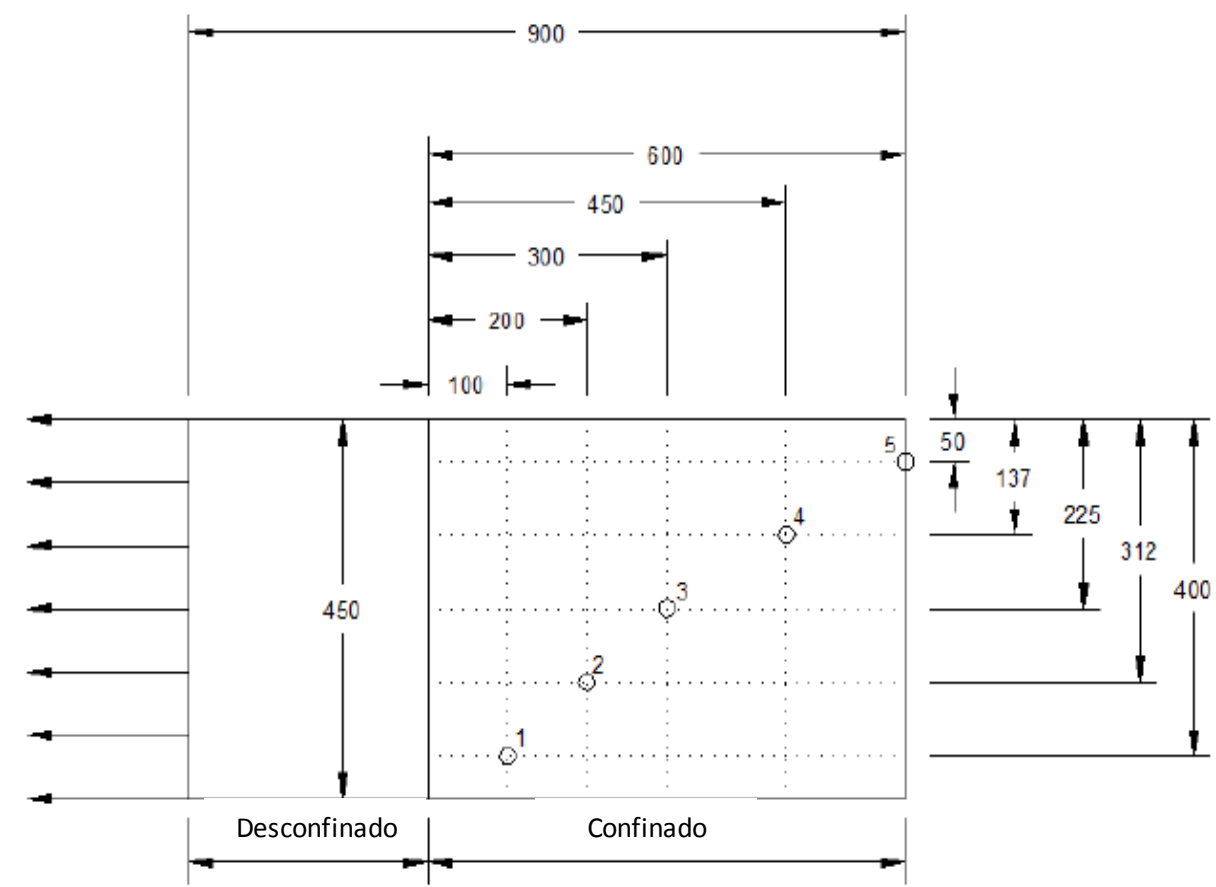

Figura 2.19 - Fixação de instrumentação para medição de deslocamentos (Adaptado de GUPTA, 2009).

Os pontos de fixação adotados na instrumentação do reforço permitem o registro de deslocamentos ao longo de todo o corpo de prova, representando detalhadamente seu comportamento. Instrumentação semelhante foi utilizada em ensaios de Alfaro (1995), Mayer (2004) e Perkins (2000).

Além de instrumentação semelhante, também foram obtidos comportamentos similares nas referências Alfaro (1995) e ASTM 6706 (2001). O comportamento de deslocamento versus força obtido está exemplificado na Figura 2.20 a seguir, acerca dos LVDT's fixados nas posições da Figura 2.19 anterior. 


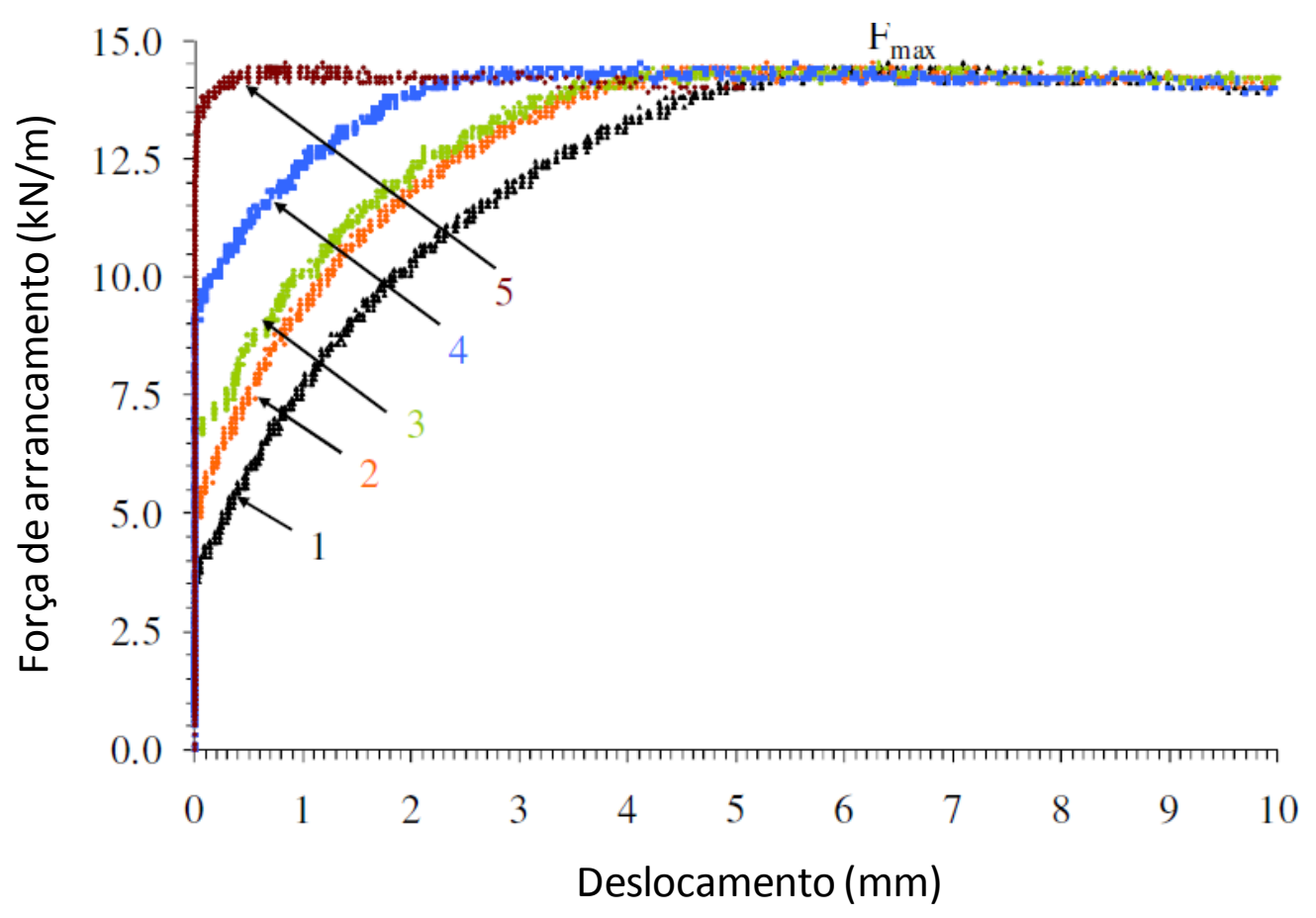

Figura 2.20 - Força de arrancamento frontal versus curvas de deslocamento dos LVDT's 1, 2, 3, 4 e 5 (Adaptado de GUPTA, 2009).

No gráfico anterior nota-se que os deslocamentos se iniciam pelos sensores posicionados mais próximos à aplicação da força (1, 2 e 3), e com o aumento da força ocorre deslocamentos nos sensores posicionados ao final do corpo de prova ancorado.

Alfaro (1995) reporta o mecanismo de interação de geogrelha utilizando os deslocamentos pontuais obtidos, e transformando-os em comprimento mobilizado da geogrelha através de associações de deslocamentos registrados com características tensãodeformação da geogrelha utilizada.

Tal tratamento foi considerado também por Gupta (2009), gerando o gráfico (Figura 2.21) que correlaciona a força de arrancamento aplicada aos deslocamentos nos diferentes pontos do reforço, mostrando a força necessária à mobilização de partes específicas da amostra. 


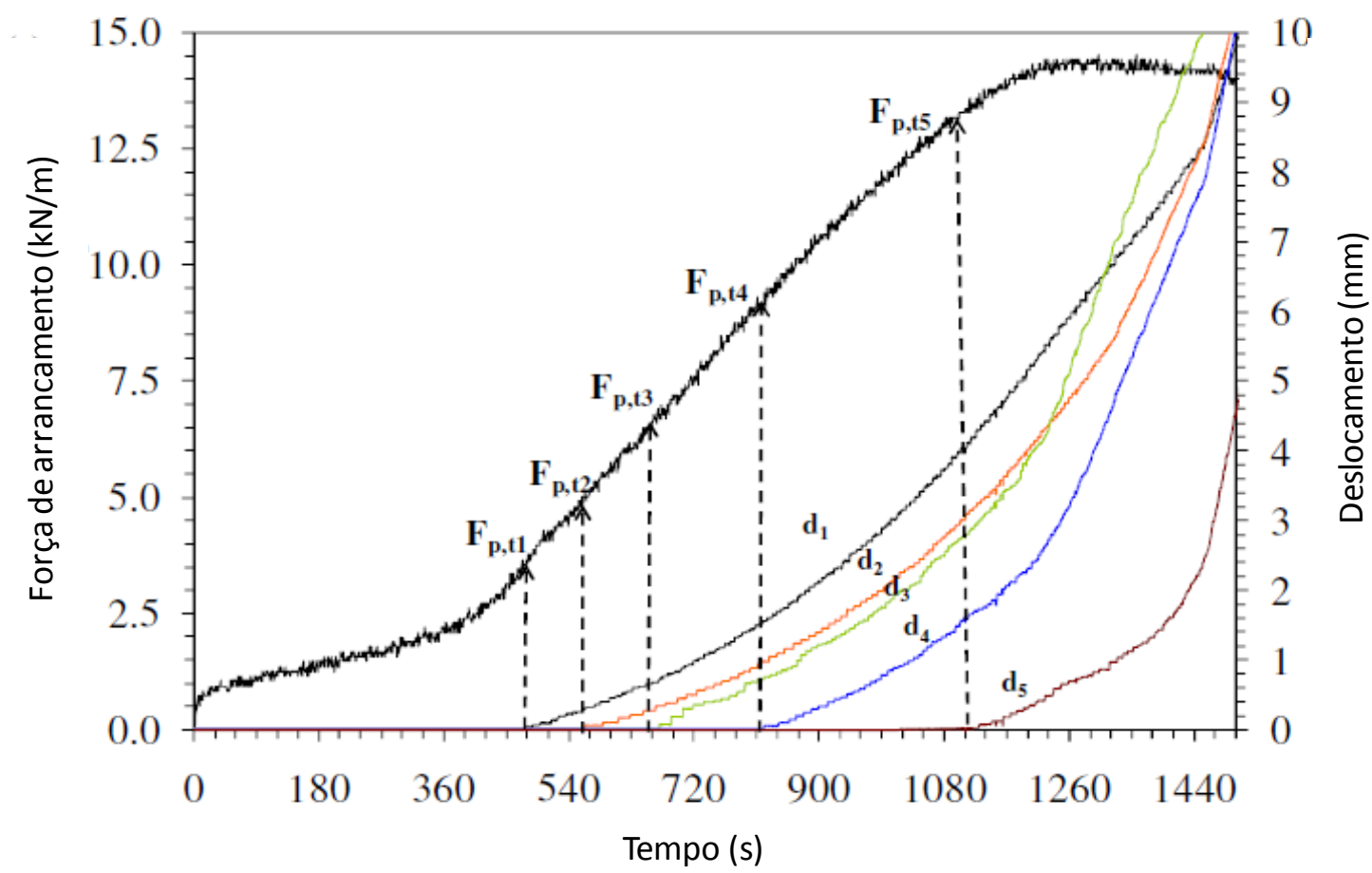

Figura 2.21 - Força de arrancamento frontal em função do tempo de ensaio, e deslocamento em função to tempo de ensaio (Adaptado de GUPTA, 2009).

Através de análise dos gráficos expostos, Gupta (2009) considerou que o início de registro de deslocamento correspondeu ao comprimento ativo do reforço.

O comportamento de arrancamento de amostras de PEAD utilizando diferentes comprimentos de ancoragens é detalhado em Moraci (2006). Neste caso o mecanismo de interação de arrancamento se desenvolve progressivamente ao longo do corpo de prova, com um aumento progressivo de resistência ao arrancamento com o aumento do deslocamento. No caso de inclusão menor o mecanismo de interação se desenvolve quase ao mesmo tempo ao longo de toda a amostra, e após a carga de pico há uma diminuição gradual da resistência ao arrancamento. Nesta pesquisa de Moraci (2006) foi comparado graficamente o comportamento de diferentes tamanhos de inclusão, ilustrados na Figura 2.22 a seguir. 

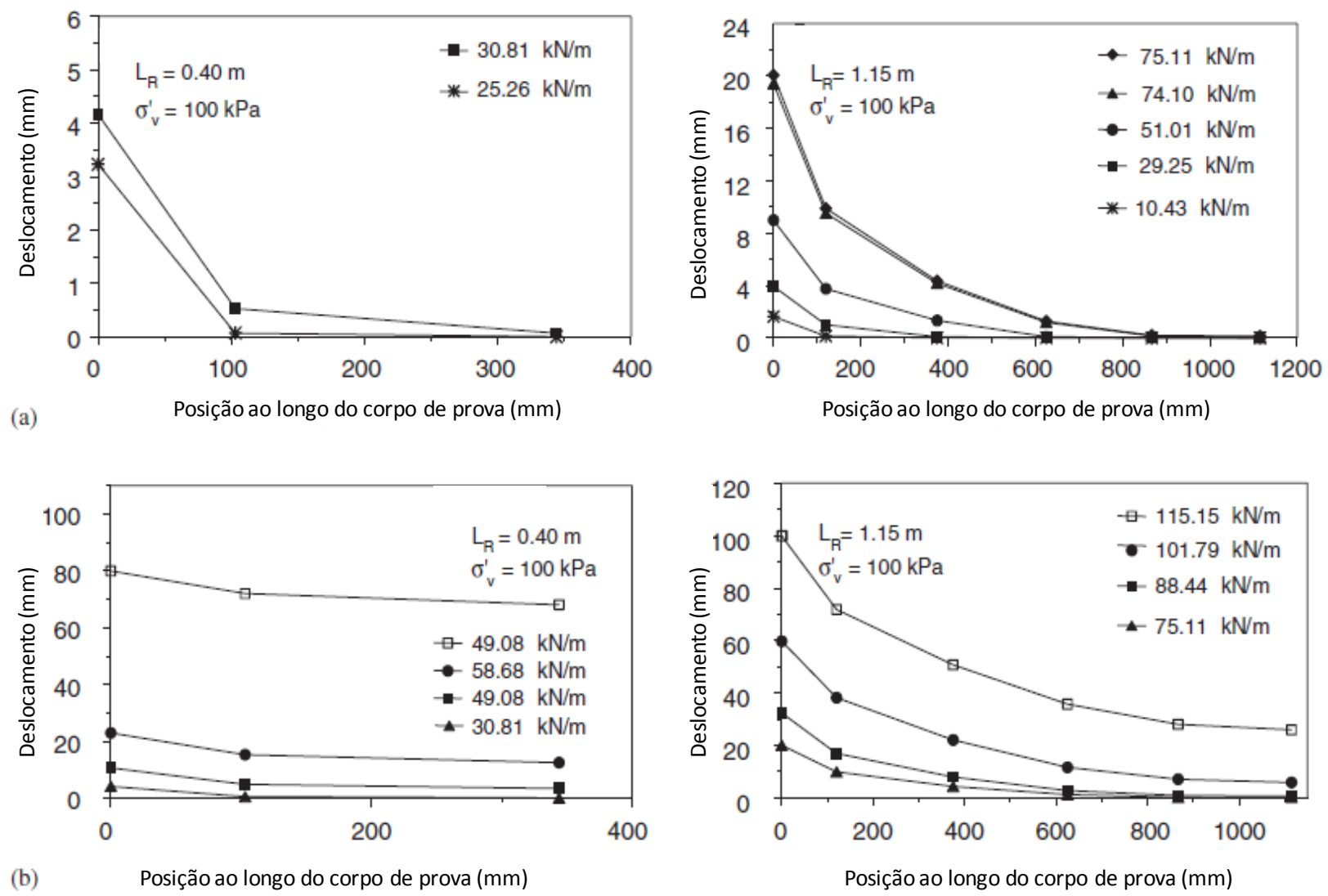

Figura 2.22 - Deslocamentos ao longo do corpo de prova; Transferência de força de tração (a) e fase de arrancamento (b) (Adaptado de MORACl, 2006).

Outro fator muito importante quanto ao comportamento de reforços com geogrelhas é a resistência dos elementos transversais ou elementos de arraste. A respeito deste comportamento foram realizadas pesquisas por TEIXEIRA (2003), que concluiu que cerca de metade da resistência ao arrancamento gerada por uma geogrelha é proveniente da ancoragem dos elementos transversais conforme se ilustra na Figura 2.23 a seguir.

Através de ensaios de arrancamento, de tração em elementos e de resistência na junção, Bowman (2012) mostra o comportamento de reforços em relação à influência dos elementos transversais. Os resultados gerados nos ensaios de arrancamento resultaram na ruptura dos elementos transversais, soltando-os dos longitudinais. Foram mostrados comportamentos de arrancamento comparando-se diversos tipos de geogrelhas extrudadas, tecidas e triaxiais utilizadas para reforço de base de brita, sujeita a cargas cíclicas de placa, e 
mostrando que a geogrelha extrudada apresentou melhor desempenho que a tecida e não extrudada, porem, estas apresentaram melhor desempenho quanto à deformação do solo, do que sem a utilização de reforços.

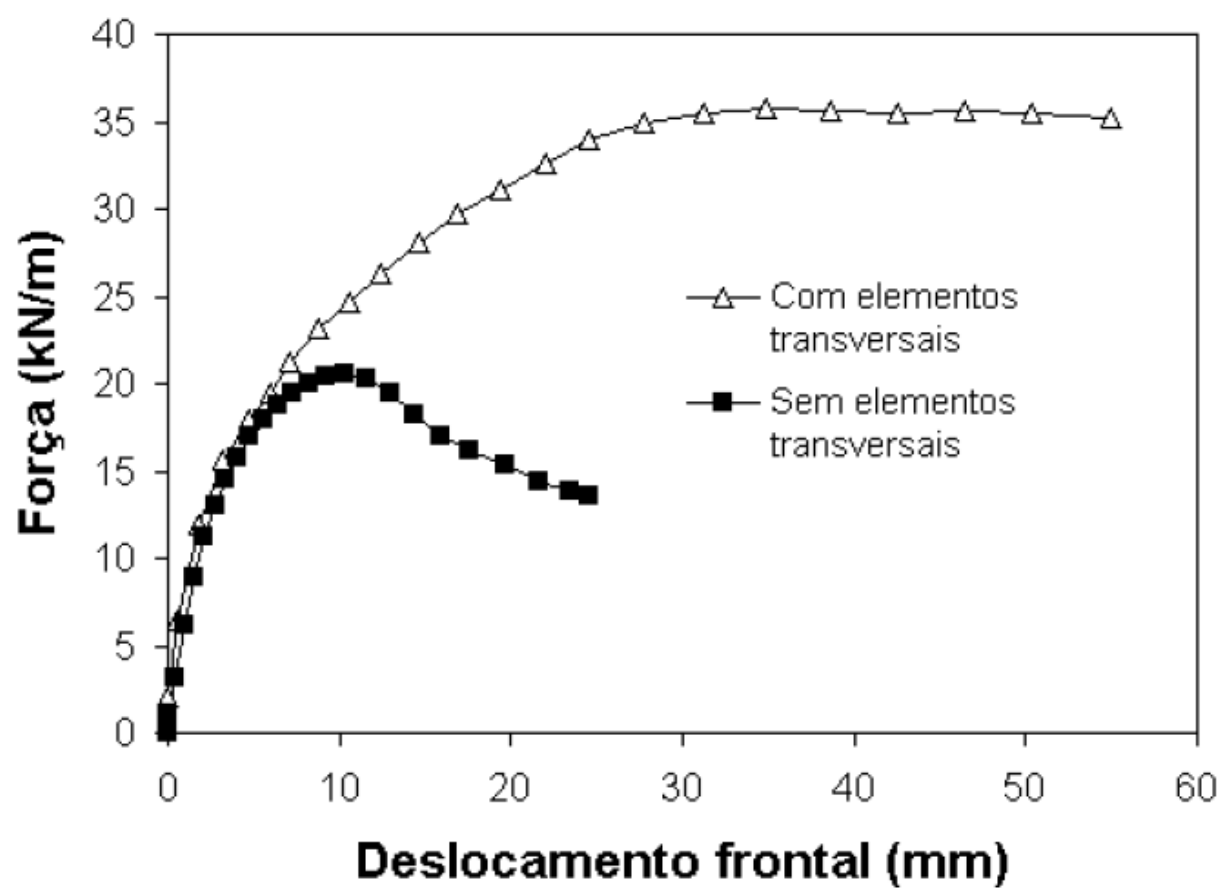

Figura 2.23 - Resistência ao arrancamento com e sem elementos transversais (TEIXEIRA, 2003).

Outros dados importantes a respeito do comportamento de geogrelhas ao arrancamento foram os testes onde as geogrelhas que apresentavam maior resistência na junção entre os elementos transversais e longitudinais apresentaram ainda maior resistência ao arrancamento, ligando o fato da resistência ao arrancamento estar intimamente ligada ao arraste dos elementos transversais. Em regra geral ensaios isolados de resistência de geogrelhas na direção de arrancamento (ensaios de força de ligação de elementos) com resultados maiores, indicam resistência ao arrancamento maiores também. Globalmente a melhora de desempenho de agregado de base é proporcional ao aumento das propriedades índices da geogrelha utilizada. Baseado neste estudo, conclui-se que a força de elemento à baixa deformação e resistência ultima da junção da geogrelha, estão entre as propriedades índices mais relevantes 
para reforço de base independente do tipo de geogrelha (extrudada, costurada). Além disso, como recomendado por Bowman (2012) o valor mínimo de resistência à tração na junção de geogrelhas novas deve ser de $11,34 \mathrm{~kg}$.

Palmeira (2009) reforça a importância dos elementos transversais na interação da geogrelha com o solo, mostrando que uma geogrelha com baixa rigidez está mais sujeita a arraste e deformação dos membros transversais, como ilustrado na Figura 2.24 a seguir.

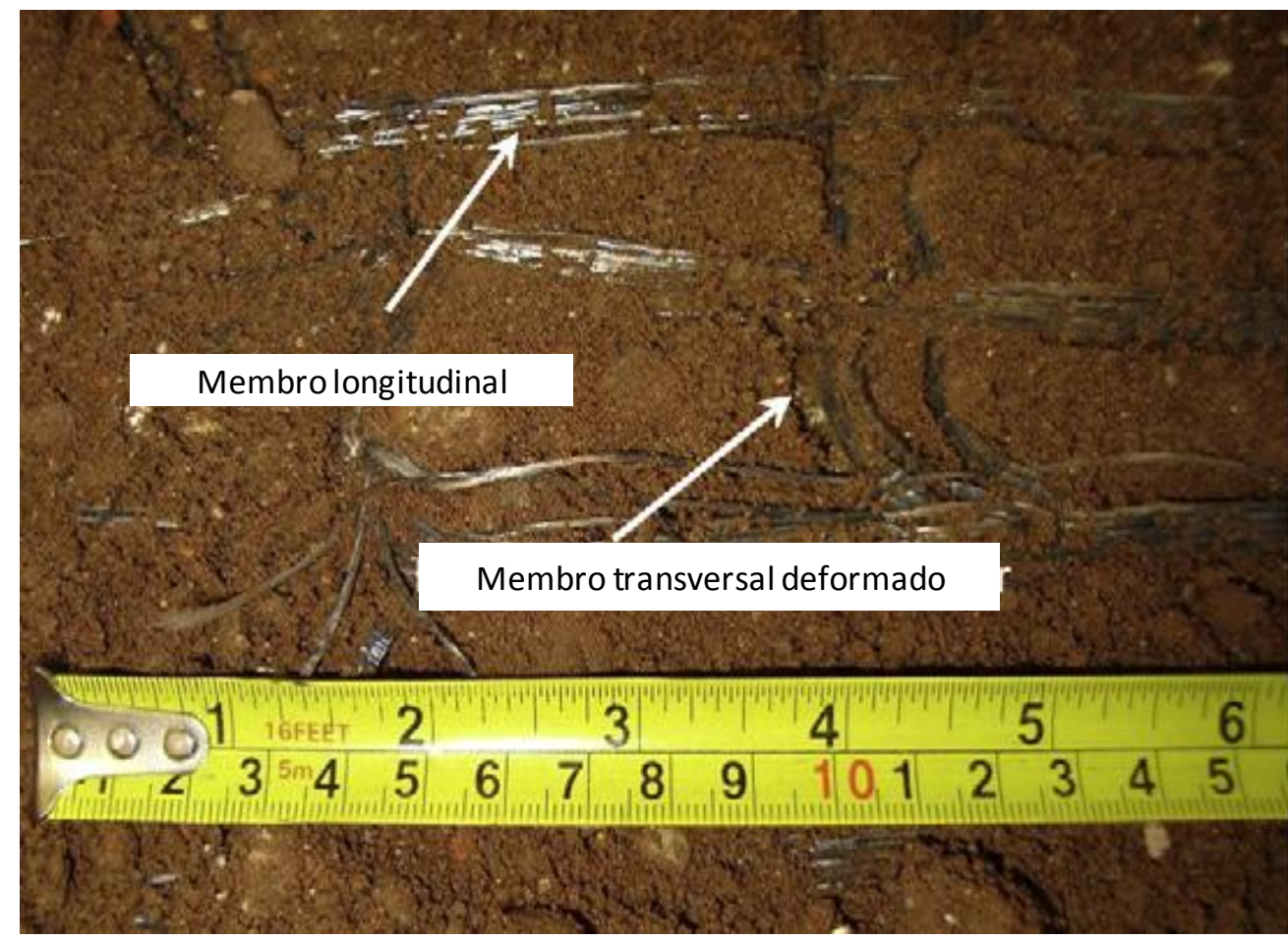

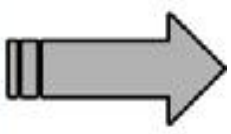

Força de arrancamento

Figura 2.24 - Deformação dos membros longitudinais (Adaptado de PALMEIRA, 2009).

A forma e a rigidez dos elementos transversais são aspectos que tem influência sobre o comportamento de arrancamento da geogrelha (PALMEIRA, 2009) e não são considerados em modelagem através de elementos finitos. Para membros transversais com baixa rigidez uma mobilização progressiva terá lugar com a curvatura dos membros sob uma crescente força de arrancamento. Considerando-se que as análises por métodos de elementos finitos (FEM) consideram a geogrelha como um reforço planar, contínuo e equivalente, no entanto, a 
resposta ao arrancamento deste tipo de reforço é fundamentalmente dependente da forma geométrica e características da geogrelha, com referência especial para os membros transversais.

\subsubsection{Ensaios cíclicos}

Ensaios cíclicos são ensaios onde são aplicadas forças ou tensões sobre um solo ou reforço, seguido do alívio das mesmas, repetindo-se o processo inúmeras vezes.

O objetivo principal destes ensaios é simular os efeitos de carregamento e descarregamento do reforço, visando se conhecer a resposta do reforço às solicitações que o mesmo irá sofrer com sua utilização. Como visto em Cuelho e Perkins (2005) os testes de interação mais relevantes que utilizam cargas cíclicas encontram ampla aplicação no reforço de pavimentação, onde o reforço, no caso um geossintético, será solicitado à tração quando houver uma sobrecarga de um veículo sobre o mesmo e terá suas solicitações aliviadas quando o veículo não estiver mais sobre ele.

Sabendo-se que o reforço sofrerá solicitações cíclicas, é de suma importância o conhecimento dos efeitos que essa ciclagem causa no material, sendo esta associada à fluência e a deformações plásticas ou elásticas que definirão a resposta do material frente às solicitações reais do reforço. Outros ensaios convencionais como o arrancamento monotônico ou a ciclagem individual nos componentes do solo reforçado podem não refletir o comportamento do conjunto, confirmando a importância deste ensaio.

Fakher (1997) realizou estudos de resistência ao cisalhamento simulando interfaces de solos argilosos com reforços de geogrelhas de diferentes polímeros (PET, PEAD e PEBD) e camadas de areia sobre o reforço. Foi apontado que a resposta de uma geogrelha de PEAD à solicitação de tração ocorre de maneira mais rápida e à uma solicitação de deformação muito 
menor que uma geogrelha de PET, quantificando a diferença de rigidez em relação ao comportamento como reforço.

Bathurst (1994) ilustra o comportamento de tração de geogrelhas de polímeros diferentes (PET e PEAD), mostrando que a velocidade do ensaio influencia pouco no comportamento à resistência da geogrelha de PET, fator que está diretamente ligado à velocidade dos ensaios cíclicos, pois o tempo da ciclagem está diretamente relacionado com a aplicação do esforço de tração no material confinado. São exibidos gráficos (Figura 2.25 (a) e (b)) a seguir sobre o comportamento das geogrelhas de PET e PEAD submetidas à ciclagem.

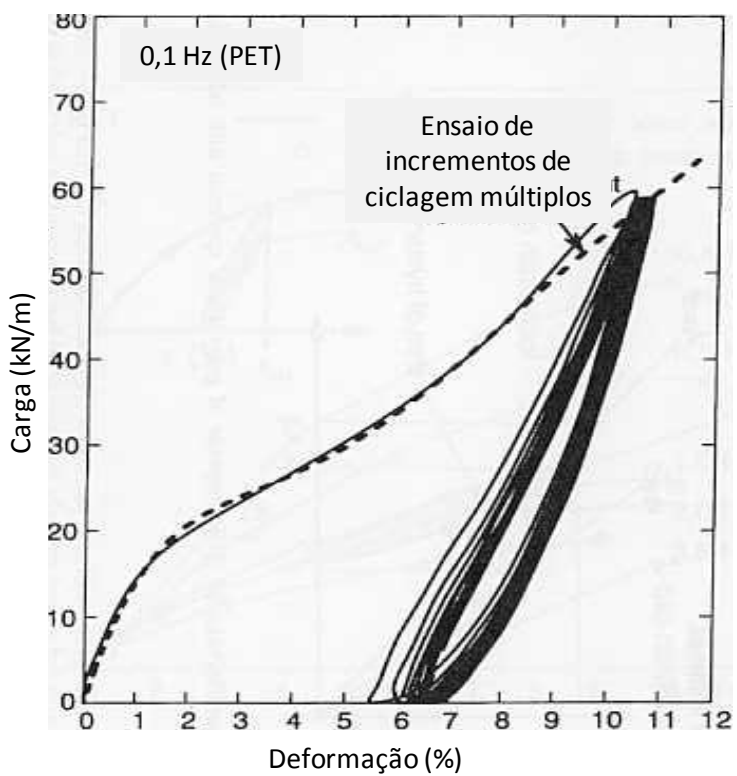

(a)

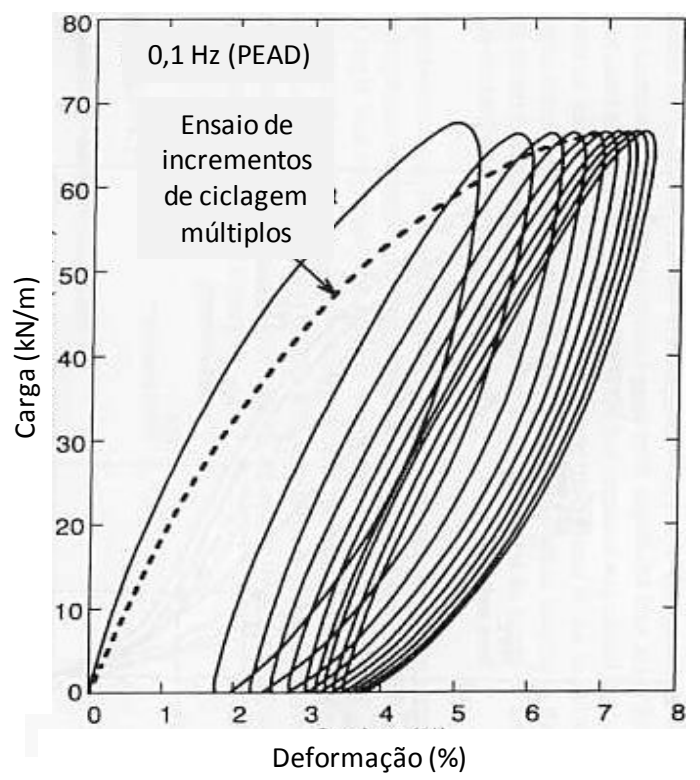

(b)

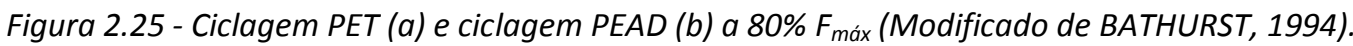

Para a geogrelha de PET ocorre comportamento estável quanto à ciclagem em nível único e em níveis múltiplos de carregamento, diferente do material de PEAD que mostra instabilidade de comportamento quanto à velocidade de tração e comportamento quanto à ciclagem. Kongkitkul (2004) através de estudos semelhantes de ciclagem apresenta um 
comportamento mais deformável e variável da geogrelha de PEAD e menos deformável e mais estável para a geogrelha de PVA.

Outra forma de avaliar o comportamento cíclico de materiais é através do módulo resiliente. Cuelho e Perkins (2005) mediram o módulo resiliente de cisalhamento de interface $\left(G_{i}\right)$, definido como a relação entre a tensão cíclica de cisalhamento na interface sologeossintético, e o deslocamento resiliente relativo entre o agregado e o reforço para a tensão cisalhante aplicada. Para tanto usaram os valores máximos e mínimos de deslocamentos e cargas provenientes dos últimos dez ciclos de cada nível de confinamento, dentro de cada sequência de grupo. A Figura 2.26 a seguir exemplifica como ocorrem os ciclos de carregamentos e descarregamentos do sistema, assim como as deformações relativas entre cada ciclo e os respectivos acúmulos de deformações permanentes, fornecendo parâmetros de cálculo do módulo de resiliência $\left(G_{i}\right)$.

O trabalho de Cuelho e Perkins (2005) enfatiza a importância da concepção de uma norma específica a respeito do comportamento sobre ciclagem de materiais, qualificando a interação solo-geossintético, fato que ocorreu em 2009 com a edição, pela ASTM, da designação D 7499/D 7499M (2009).

Os resultados de ensaios de resiliência na interface entre o solo e o reforço aplicado, encontram aplicação nos métodos de projeto que empregam princípios mecanísticos, como o desenvolvido por PERKINS et al (2004). 


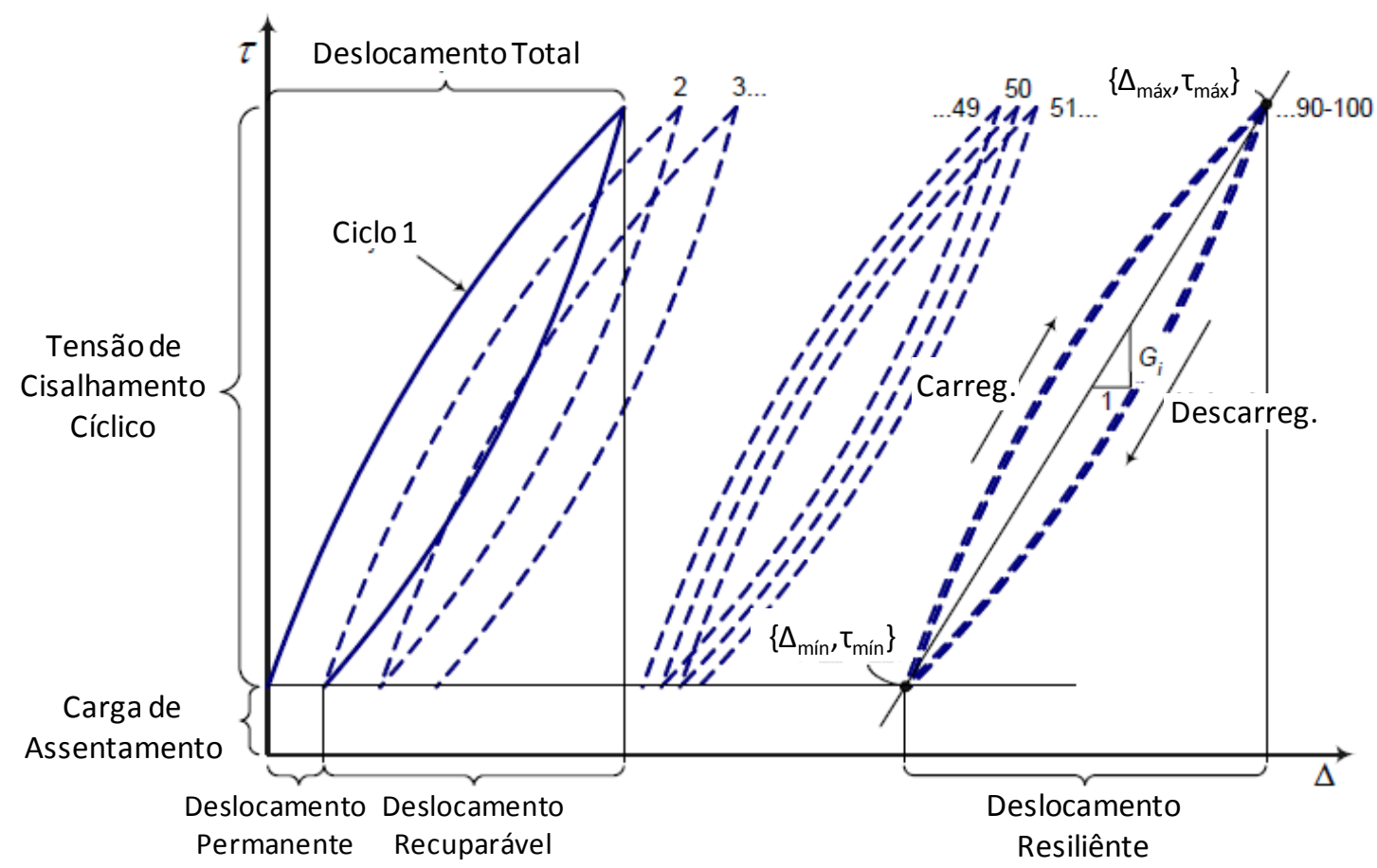

Figura 2.26 - Funcionamento da ciclagem e módulo de cisalhamento de interface (Adaptado de CUELHO e PERKINS, 2005).

$\mathrm{Na}$ pesquisa de Cuelho e Perkins (2005) foram utilizados seis tipos diferentes de geossintéticos de Polipropileno (PP), sendo três geogrelhas e três geotêxteis, denominados Geosynthetics A, B, C, D, E, F e G. O equipamento utilizado no ensaio tomou por base a caixa de ensaios normatizada pela ASTM D 6706 (2003), referente a ensaios de arrancamento, com mudança na configuração de aplicação de carga adaptada à ciclagem, como na Figura 2.27 a seguir.

Para a realização dos ensaios de arrancamento cíclico (CUELHO e PERKINS, 2005) foi adaptado um protocolo proveniente da norma para determinação de módulo resiliente (MR) de NCHRP (2000), onde se utilizava uma série de passos consistindo de diferentes níveis de tensões de confinamento e tensões cíclicas axiais. 


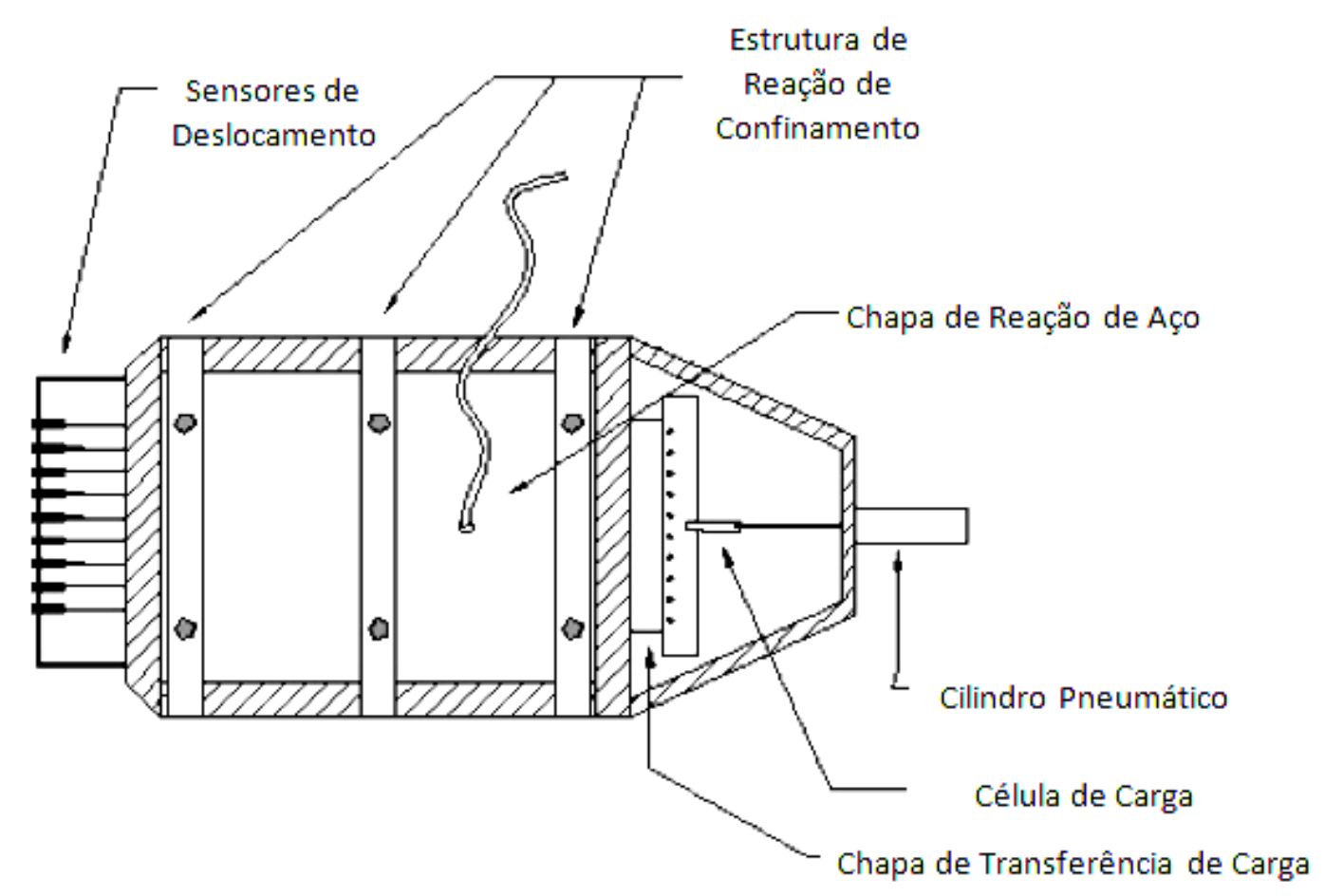

Figura 2.27 - Vista em planta da caixa de arrancamento (Adaptado de CUELHO e PERKINS, 2005).

A realização dos ensaios se iniciou com a aplicação de 1000 ciclos na amostra sob um confinamento de 51,7 $\mathrm{kPa}$, visando minimizar as anomalias inerentes a experimentos associados a solos compactados. Após este passo de condicionamento seis sequências de carregamentos separados foram seguidas (Figura 2.28) baseadas na envoltória de resistência de interface. 


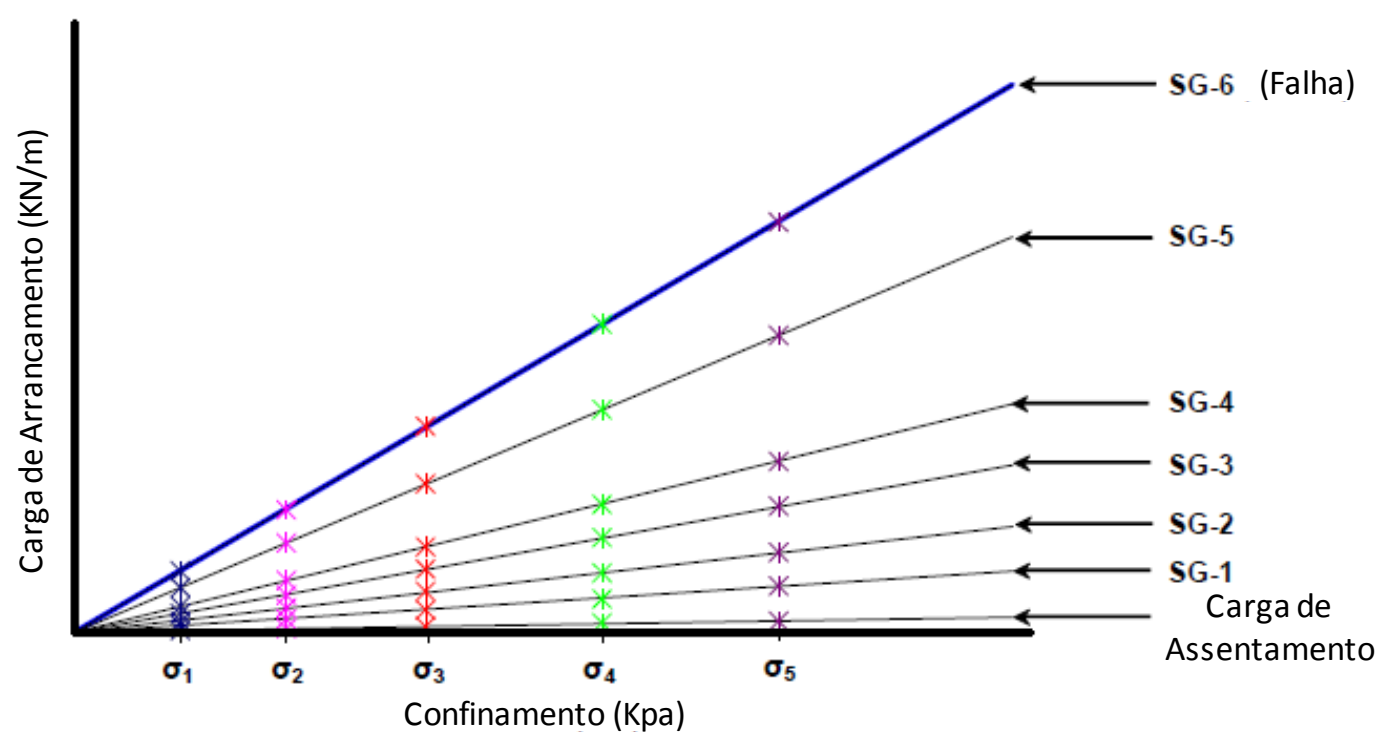

Figura 2.28 - Procedimento de carregamento de arrancamento cíclico (Adaptado de CUELHO e PERKINS, 2005).

A sexta sequência de carregamento representa a linha de ruptura e as cinco sequências restantes foram baseadas em uma porcentagem da primeira, segundo a Tabela 2.1 a seguir.

Em Cuelho e Perkins (2005) foram utilizados cinco níveis de confinamento (15,5; 31,0; 51,7; 77,6 e 103,4 $\mathrm{kPa}$ ) e cada sequência de carga define a linha chamada de sequência de grupo. Os ensaios se iniciam com a sequência de grupo de menor confinamento primeiro (SG-1) e progressivamente até a sexta sequência de grupo (SG-6), a menos que ocorra uma falha de arrancamento antes.

\begin{tabular}{cc}
\hline $\begin{array}{c}\text { Nível de } \\
\text { Carga }\end{array}$ & $\begin{array}{c}\text { Porcentagem } \\
\text { de Falha }\end{array}$ \\
\hline Carga de Assentamento & $2.8 \%$ \\
SG 1 & $9.7 \%$ \\
SG 2 & $16.7 \%$ \\
SG 3 & $30.6 \%$ \\
SG 4 & $44.4 \%$ \\
SG 5 & $72.2 \%$ \\
SG 6 & $100.0 \%$ \\
\hline
\end{tabular}

Tabela 2.1 - Porcentagem de cargas de falhas para cada sequencia de grupo (Adaptado de CUELHO e PERKINS, 2005). 
A carga de cisalhamento cíclica é aplicada entre os valores no estado de linha de carga máxima e os pontos da sequência de grupo. Cargas máximas e mínimas aplicadas no geossintético para uma etapa de carregamento particular são determinadas pelo grupo de sequência e pelo estado de linhas de cargas respectivamente. Para os dois primeiros níveis de confinamento são aplicados 300 ciclos de cargas cisalhantes para garantir que o comportamento cisalhante se estabeleceu. Para os confinamentos restantes foram aplicados 100 ciclos de cargas cisalhantes.

A tensão cisalhante foi determinada dividindo-se a carga aplicada pela área de geossintético envolvida, que foi duplicada para incluir a parte superior e inferior do geossintético. A área do geossintético incorporado reduz levemente com o andar do teste tornando necessária a correção da área. Isto é feito pela subtração do deslocamento máximo da parte de trás da amostra proveniente do comprimento embutido.

$\mathrm{Na}$ equação da tensão cisalhante $(\tau)$ a seguir (Equação 2.5), $F$ é a carga aplicada, 2 representa os dois lados do material, $w$ é a largura do material, $l$ é o comprimento da amostra e $\Delta_{b}$ é o deslocamento médio da parte de trás da amostra.

$$
\tau=\frac{F}{2 * W *\left(l-\Delta_{b}\right)}
$$

Ainda na pesquisa de Cuelho e Perkins (2005) é considerada a equação geral para a obtenção de módulo de resiliência de materiais granulares (Equação 2.6). Esta equação, como parte do projeto desenvolvido por NCHRP (2004), se baseia na dependência da tensão confinante que o módulo de resiliência apresenta. Desta forma, para expressar essa dependência utiliza-se a equação a seguir. 


$$
M_{r}=K_{1} * P_{a} *\left(\frac{\theta}{P_{a}}\right)^{K_{2}} *\left(\frac{\tau_{o c t}}{P_{a}}+1\right)^{K_{3}}
$$

Onde $P_{a}$ é a pressão atmosférica, $\theta$ é a tensão média no solo $\left(\sigma_{1}+2 . \sigma_{3}\right), \tau_{o c t}$ é a tensão octaédrica de cisalhamento $\sqrt{2 / 3} \cdot\left(\sigma_{1}-\sigma_{3}\right)$, e $K_{l}, K_{2}$ e $K_{3}$ são constantes adimensionais correspondentes a propriedades do material, que podem ser obtidas por rotina estatística de otimização por exemplo, onde $\mathrm{K}_{1}$ e $\mathrm{K}_{2}>0$ e $\mathrm{K}_{3}<0$.

Baseado nesta equação de resiliência dos solos, Cuelho e Perkins (2005) propôs a equação de determinação do módulo de cisalhamento de interface $\left(G_{i}\right)$ ilustrada a seguir (Equação 2.7) onde novas constantes adimensionais $K_{1}, K_{2}$ e $K_{3}$ são utilizadas. Agora, a tensão normal na interface $\left(\sigma_{i}\right)$ substitui a tensão no solo e a tensão de cisalhamento na interface $\left(\tau_{i}\right)$ substitui a tensão de cisalhamento octaédrica. Estas tensões ainda são normatizadas pela pressão atmosférica $\left(P_{a}\right)$.

No caso específico da pesquisa, foi utilizado um termo $\left(P_{a}\right)$ que é a pressão atmosférica dividida por uma unidade de comprimento de 1 metro, resultando na pressão máxima de confinamento $(101,3 \mathrm{kPa} / \mathrm{m})$, e isto é feito para desenvolver unidades consistentes de $G_{i}$.

$$
G_{i}=K_{1} * P_{a} *\left(\frac{\sigma_{i}}{P_{a}}\right)^{K_{2}} *\left(\frac{\tau_{i}}{P_{a}}+1\right)^{K_{3}}
$$

Pesquisas realizadas por García (2011) apontam o comportamento resiliente do conjunto solo-reforço quando ciclado a 40 e $80 \%$ da resistência ao arrancamento do material. O comportamento obtido na pesquisa de García (2011) mostra que a ciclagem do sistema sob as condições de ensaios realizadas apresentou um acréscimo na resistência ao arrancamento quando o sistema foi ciclado a $40 \%$ da carga de arrancamento. Já quando o sistema foi 
ciclado com uma porcentagem de $80 \%$ da resistência máxima ao arrancamento houve um colapso do sistema em cerca de 250 ciclagens. O comportamento geral do material é ilustrado na Figura 2.29 a seguir.

Estudo de Leng e Gabr (2002) afirma que durante o início da ciclagem o material agregado pode sofrer compactação, apresentando ligeira melhora de propriedades mecânicas, seguido de progressiva deterioração e degradação com diminuição da espessura efetiva da camada e das propriedades mecânicas. Ensaios de Moraci (2009) a respeito de arrancamento após ensaio breve de ciclagem (cerca de 15 ciclos) registraram perda de resistência que foi maior em geogrelha tecido do que em geogrelha extrudada. Foi notado ainda que o ensaio de arrancamento pós ciclagem apresenta maior resistência quando a rigidez da geogrelha é maior.

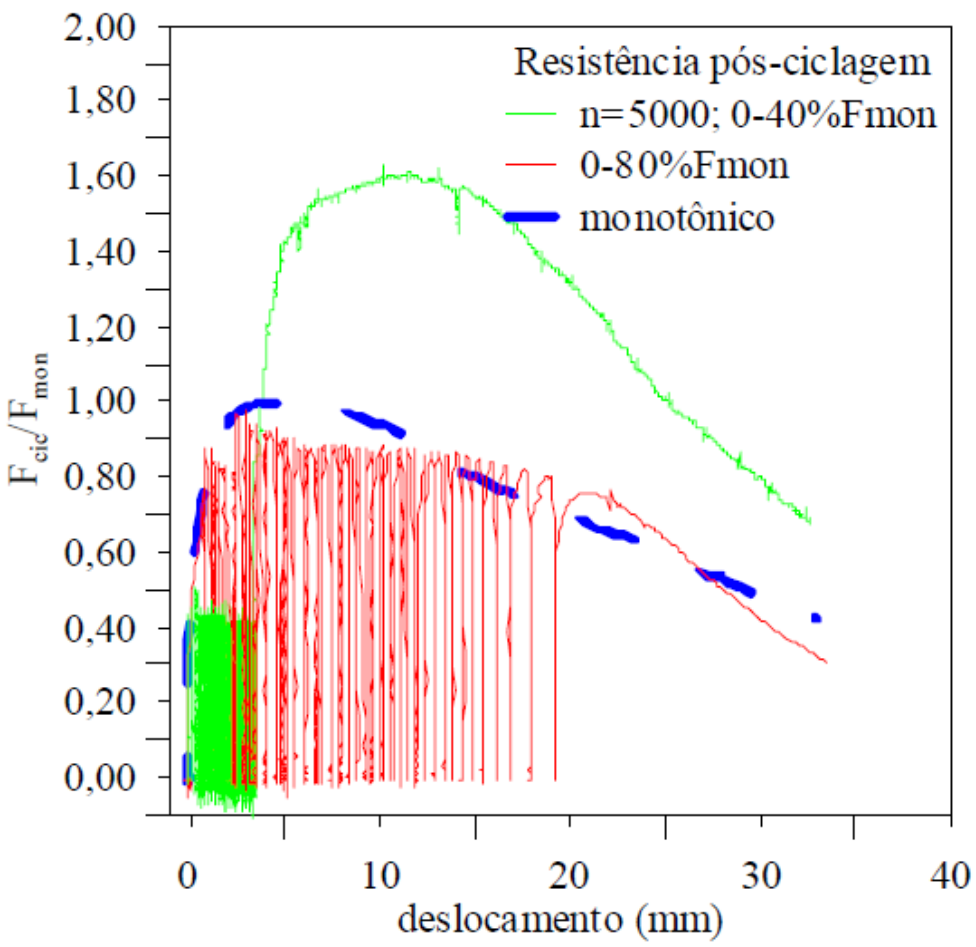

Figura 2.29 - Comparação entre casos extremos de ciclagens (40 e 80\%) em relação à resistência monotônica (GARCÍA, 2011). 
Raju (1997) realizou ensaios de arrancamento e cíclico, variando-se entre controle de deslocamento por tempo (DC - arrancamento) e repetindo-se com controle de carga por tempo (LC - ciclagem). Para a referida pesquisa, foi verificado um comportamento onde aparentemente dez ciclos são suficientes para qualquer amplitude de carga para se determinar a resposta sobre carregamento cíclico (Figura 2.30 a seguir), desde que o deslocamento acumulado nos ciclos diminua mostrando uma resposta estável. A frequência de carga parece influenciar o aumento de deslocamentos que ocorre em cada ciclo antes da ruptura no teste de carga controlada, mas não no valor limite de resistência ao arrancamento.

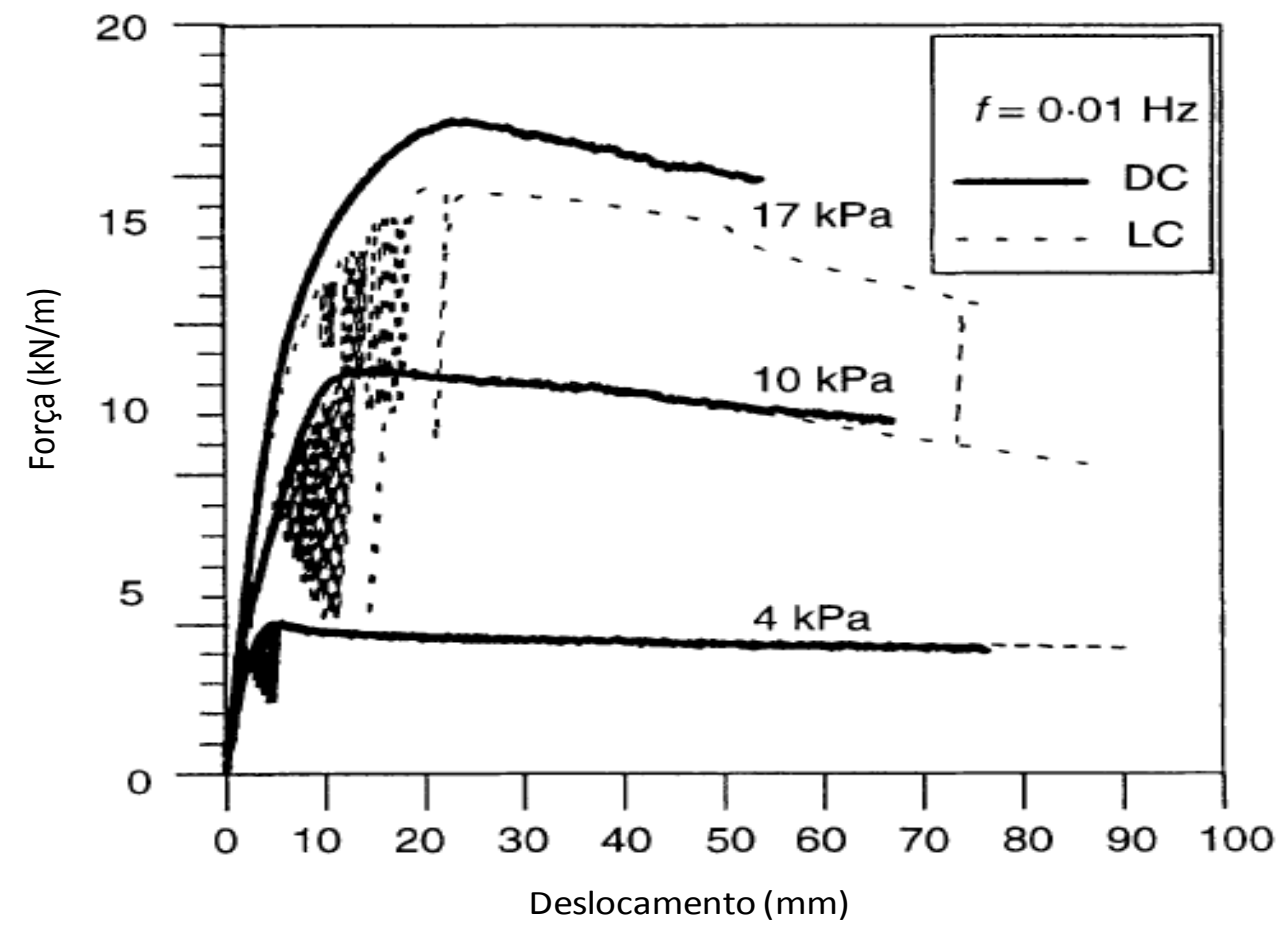

Figura 2.30 - Resistência ao arrancamento em ensaios de controle de carga (LC) e controle de deslocamento (DC) à frequência de $0,01 \mathrm{~Hz}$ (Adaptado de RAJU, 1997).

Moraci (2012) estudou o comportamento cíclico e de arrancamento de geogrelhas em areia média, e observou que as deformações principais ocorrem nos primeiros 10 a 15 ciclos e em locais próximos à garra. Foi obtido comportamento de ciclagem de interface estável, e apenas para confinamento maior e com maior amplitude de ciclagem ocorreu o acumulo de 
deslocamento levando ao arrancamento do material. Foi observado que o aumento da amplitude da ciclagem aumenta o deslocamento acumulado. As geogrelhas extrudadas mostraram uma resposta mais rígida de carga de arrancamento cíclico em relação às geogrelhas tecidas.

A norma específica a respeito da medição da rigidez de cisalhamento de interface solo-geossintético (ASTM 7499, 2009) afirma que pode ser utilizada para qualquer tipo de geossintético e qualquer tipo de solo e para finalidades de verificação de comportamento e pesquisa. Ela detalha como o carregamento é aplicado ao geossintético incorporado ao solo para determinar a rigidez aparente da interface solo-geossintético.

São especificados ainda detalhes a respeito do equipamento necessário à realização do ensaio como a caixa de ensaios (Figura 2.31), disposição do material ensaiado, instrumentação, sistema de reação e confinamento normal e dispositivo de carregamento cíclico.

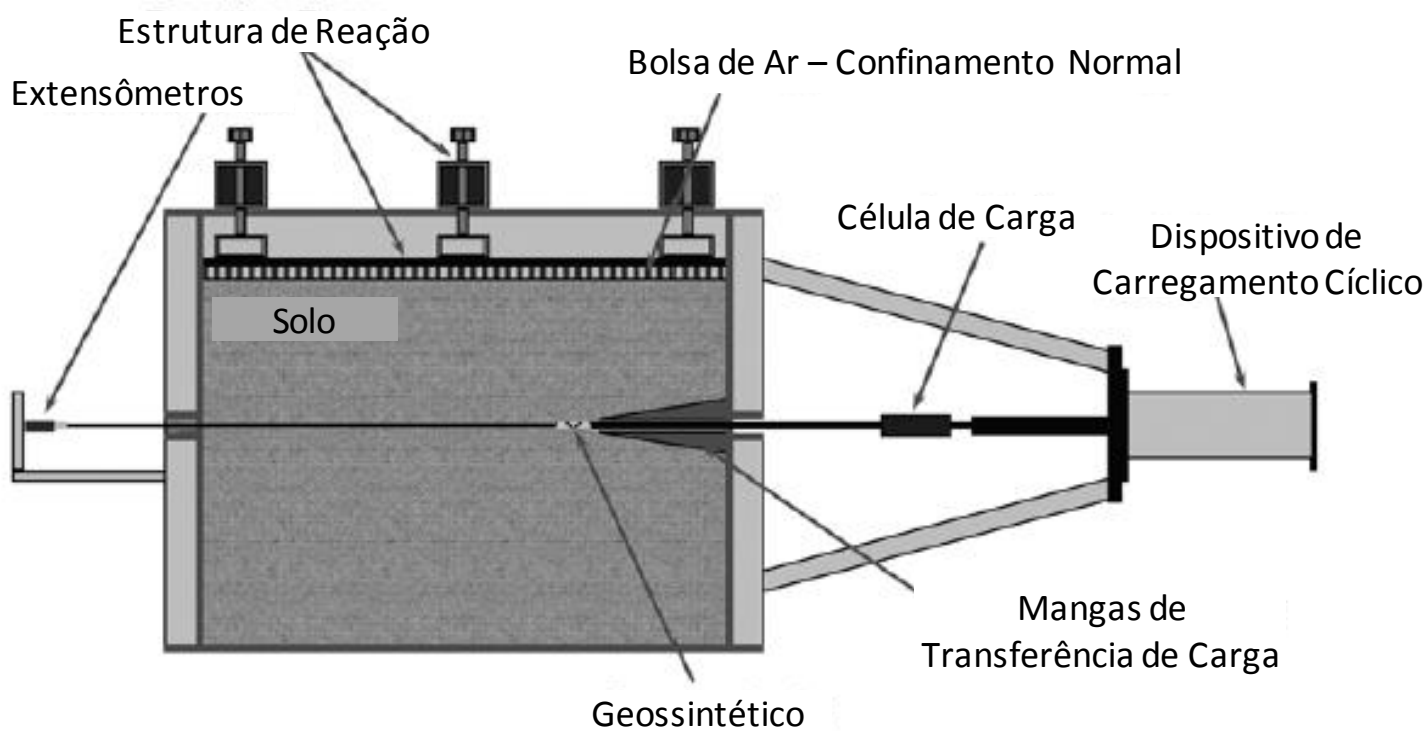

Figura 2.31 - Vista lateral de um dispositivo de ensaio típico (Adaptado de ASTM 7499, 2009). 
O carregamento de confinamento normal aplicado deve ser mantido constante e dependerá dos requisitos e finalidades de cada tipo de ensaio. O dispositivo de aplicação do carregamento cíclico deve estar apto a aplicar carregamento cíclico na direção da abertura da caixa e a magnitude da força deve ser equiparada com a do reforço ensaiado. O sistema de carregamento cíclico deve ser capaz de aplicar múltiplas repetições de pulsos consistindo de intervalos de carregamento de 0,2 segundos e descanso de 0,8 segundos simultaneamente, mantendo um mínimo de carga assentada no corpo de prova durante o carregamento cíclico, além de recomendações para o sistema de medição da força de ciclagem a ser incorporado no sistema. Detalhes como precisão e posicionamento de indicadores de deformação e sistemas de afixação do corpo de prova também são descritos na norma (ASTM 7499, 2009) assim como recomendações a respeito do equipamento de preparação do solo a ser utilizado no ensaio.

Holley (2009) realizou ensaios de módulo de resiliência em geogrelhas e discutiu o procedimento proposto por Perkins (2004). Ele afirma não ter influência o tempo de ciclagem entre 0,2 e 0,8 segundos de pulso de carga e descanso para areias. A Figura 2.32 a seguir mostra alguns resultados de Holley (2009) referentes à carga baixa de ciclagem e sequência de ciclagem em carga alta. Apenas as ciclagens com cargas mais altas começam a refletir o comportamento esperado de carga e descarga, onde há deslocamentos mais delineados e coerentes. 


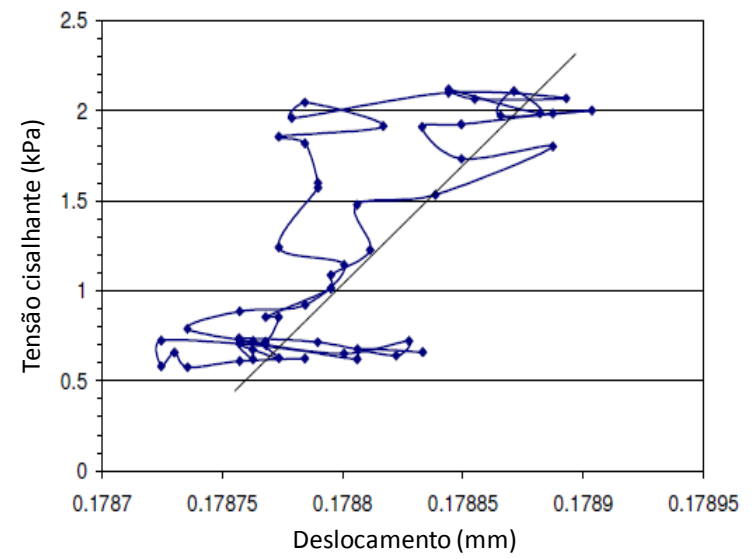

(a)

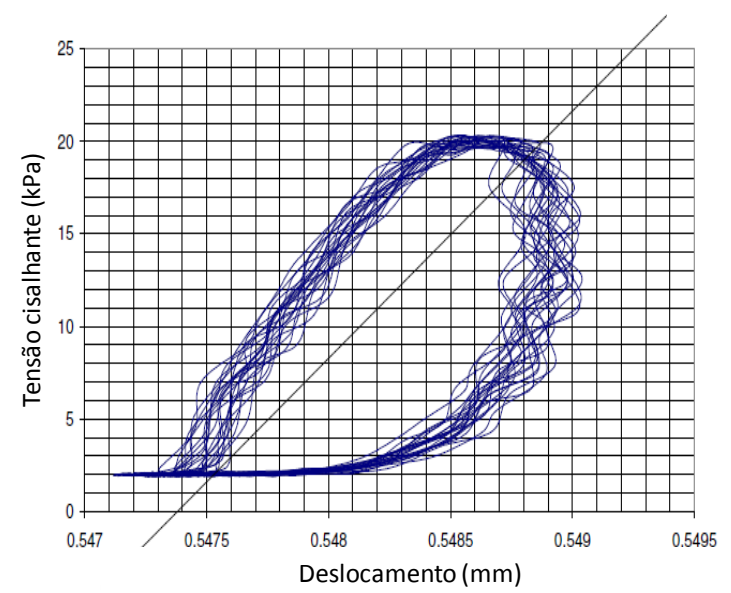

(b)

Figura 2.32 - Dados cronometrados e (a) calculo manual do $G_{i}$ em cargas baixas e (b) dados cronometrados com altas cargas cisalhantes (Adaptado de HOLLEY, 2009).

A Norma ASTM 7499 (2009) especifica o método de cálculo para obtenção da força cíclica máxima e para o módulo de resiliência de cisalhamento de interface. A Equação 2.8 para cálculo de força cíclica máxima $\left(F_{\text {máx }}-k N\right)$ mostrada a seguir, utiliza tensão cíclica cisalhante total máxima ( $\left.\tau_{\text {máx }}-k P a\right)$, largura $\left(L_{g}-\right.$ metros $)$ e comprimento $\left(C_{g}-\right.$ metros $)$ do geossintético.

$$
F_{\text {máx }}=\tau_{\text {máx }}\left(2 * L_{g} * C_{g}\right)
$$

A tensão total $\left(\sigma_{N}-k P a\right)$ aplicada ao corpo de prova dada pela Equação 2.9 a seguir considera fatores como peso da camada de solo acima do geossintético $\left(\sigma_{s}-k P a\right)$ e a tensão normal $\left(\sigma_{a}-k P a\right)$ aplicada ao conjunto.

$$
\sigma_{N}=\sigma_{s}+\sigma_{a}
$$

Para o cálculo do módulo de resiliência de cisalhamento de interface são considerados diversos fatores como deslocamento médio máximo ( $\Delta_{\text {máx }}-$ metros) do geossintético em um dado ciclo, deslocamento médio mínimo $\left(\Delta_{\min }-\right.$ metros$)$ do geossintético em um dado ciclo,

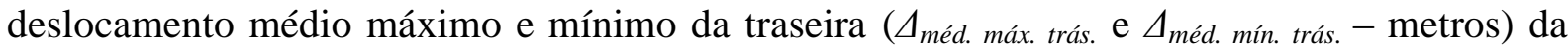


amostra (final da ancoragem) em um dado ciclo, respectivamente, e deslocamento médio

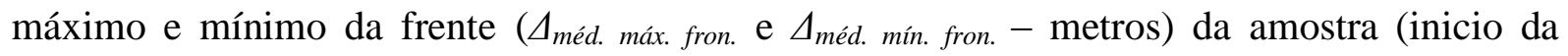
ancoragem) em um dado ciclo respectivamente, resultando na Equação 2.10 e Equação 2.11 a seguir.

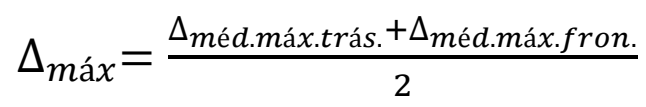

e,

$$
\Delta_{\text {mín }}=\frac{\Delta_{\text {méd.mín.trás. }+\Delta_{\text {méd.mín.fron. }}}^{2}}{2}
$$

Os parâmetros obtidos nestas equações combinados aos parâmetros de equações de tensão cisalhante cíclica total máxima e mínima $\left(\tau_{m a ́ x}\right.$ e $\left.\tau_{m i n}-k P a\right)$ mostrado a seguir (Equação 2.12 e 2.13$)$, onde se utiliza o deslocamento médio permanente acumulado ( $\Delta_{\text {méd. acu. perm. }-}$ metros) induzido pelo arrancamento e comprimento ancorado inicial do geossintético $\left(L_{0}-\right.$ metros), são utilizados na equação geral de módulo de resiliência de cisalhamento de interface.

$$
\tau_{\text {máx }}=\frac{F_{\text {máx }}}{2 * L_{g} *\left(C_{0}-\left(\Delta_{\text {méd.acu.perm. }}+\Delta_{\text {méd.máx.tras. }}\right)\right)}
$$

e,

$$
\tau_{\text {mín }}=\frac{F_{\text {mín }}}{2 * L_{g} *\left(C_{0}-\Delta_{\text {méd.acu.perm. })}\right.}
$$

A equação geral de resiliência de cisalhamento de interface $\left(G_{i}-\mathrm{kPa} / \mathrm{m}\right)$ utiliza parâmetros obtidos nas equações anteriores (Equação 2.12 e 2.13), e é dado pela Equação 2.14 a seguir. 


$$
G_{i}=\frac{\tau_{m a ́ x}-\tau_{m i n}}{\Delta_{m a ́ x}-\Delta_{m i n}}
$$

Alguns itens foram testados (HOLLEY, 2009) a fim de mensurar sua influência no comportamento do material quanto à ciclagem. É indicado ainda que a variação de tensão cisalhante tem maior efeito sobre o módulo $G_{i}$ do que a variação de tensão confinante. $\mathrm{O}$ autor realizou ainda ensaio em geogrelha de PET com dois elementos (de arraste). Para este grupo de ensaios o ângulo de atrito estimado (inclinação da curva teórica) foi reduzido para 38 graus (frente a os 41 considerados para as outras geogrelhas) a fim de evitar o arrancamento do material precocemente. No geral o comportamento obtido foi semelhante aos de outras geogrelhas em outras séries de testes, com uma diminuição do $G_{i}$ com o aumento da tensão cisalhante e aumento com o aumento da tensão confinante.

Para a geogrelha de PET foram obtidos altos níveis de variações entre o modulo $G_{i}$ previsto e o calculado, mostrado na Figura 2.33 a seguir.

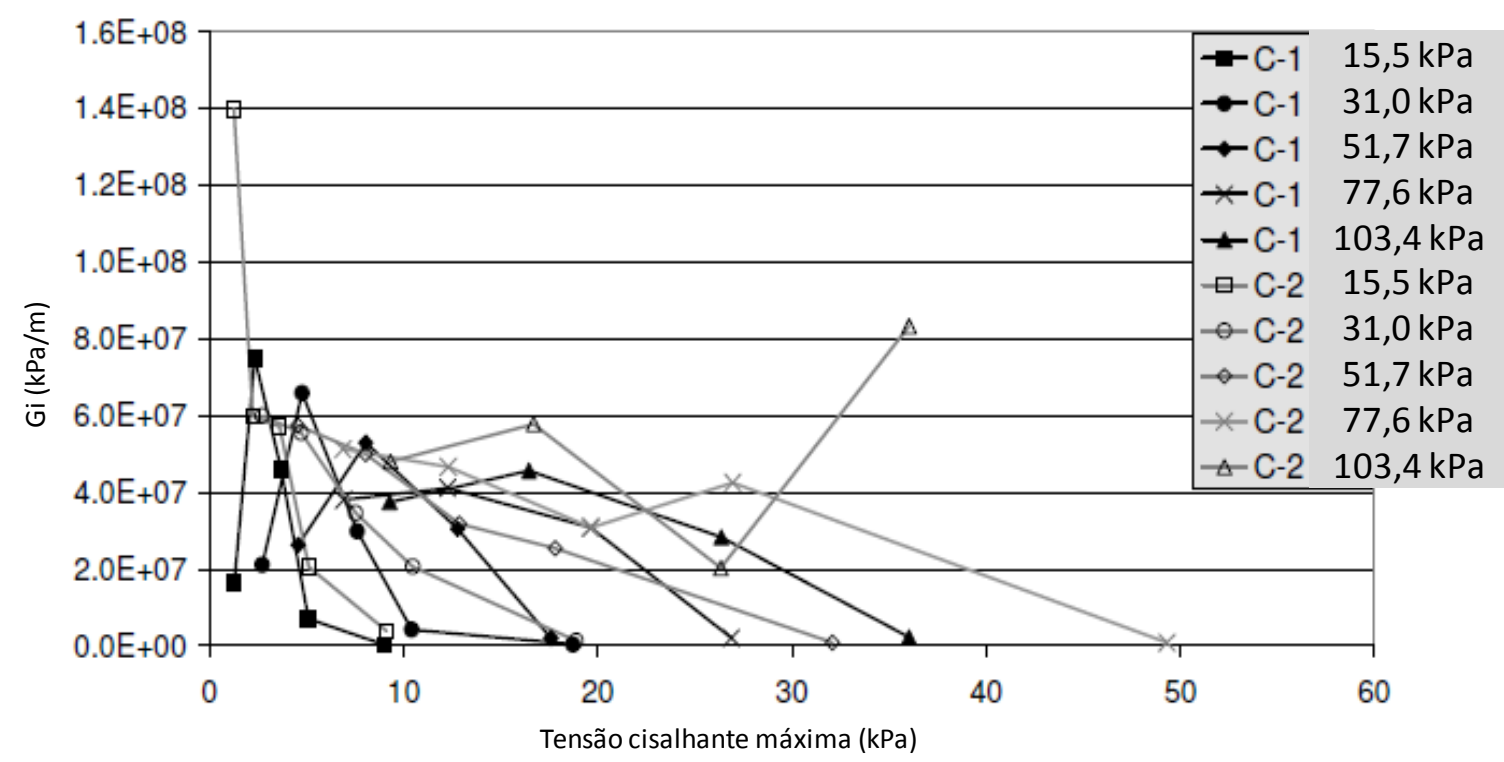

Figura 2.33 - Ensaios de ciclagem em geogrelha PET, Testes C1 e C2 (semelhantes), com tensões de 15,5 a 103,4 kPa (Adaptado de HOLLEY, 2009). 
Para esta série de testes a equação adaptada para módulo de resiliência para arrancamento cíclico não parece representar com precisão o comportamento do material. Concluiu-se que esta geogrelha de poliéster utilizada confinada na areia "otawa" não é facilmente previsível utilizando-se a equação de $G_{i}$ (Equação 2.14). Este geossintético exibiu valores geralmente mais baixos de $G_{i}$ para menores tensões cisalhantes e confinamentos, quando comparado com a geogrelha de PP. Este material também mostrou um comportamento mais irregular em relação aos outros ensaiados, com o $G_{i}$ ocasionalmente diminuído para uma dada tensão cisalhante com aumento da confinante, ou aumentado com o aumento da tensão cisalhante a uma dada confinante.

O comportamento típico descrito pela norma ASTM 7499 (2009) a respeito de módulo de resiliência de cisalhamento de interface versus tensão cisalhante se dá através de um gráfico, como ilustrado na Figura 2.34 a seguir, semelhante ao desenvolvido por Cuelho e Perkins (2005) que utilizou geogrelhas de PP em faixa curta (cerca de $80 \mathrm{~mm}$ ) de comprimento de ancoragem.

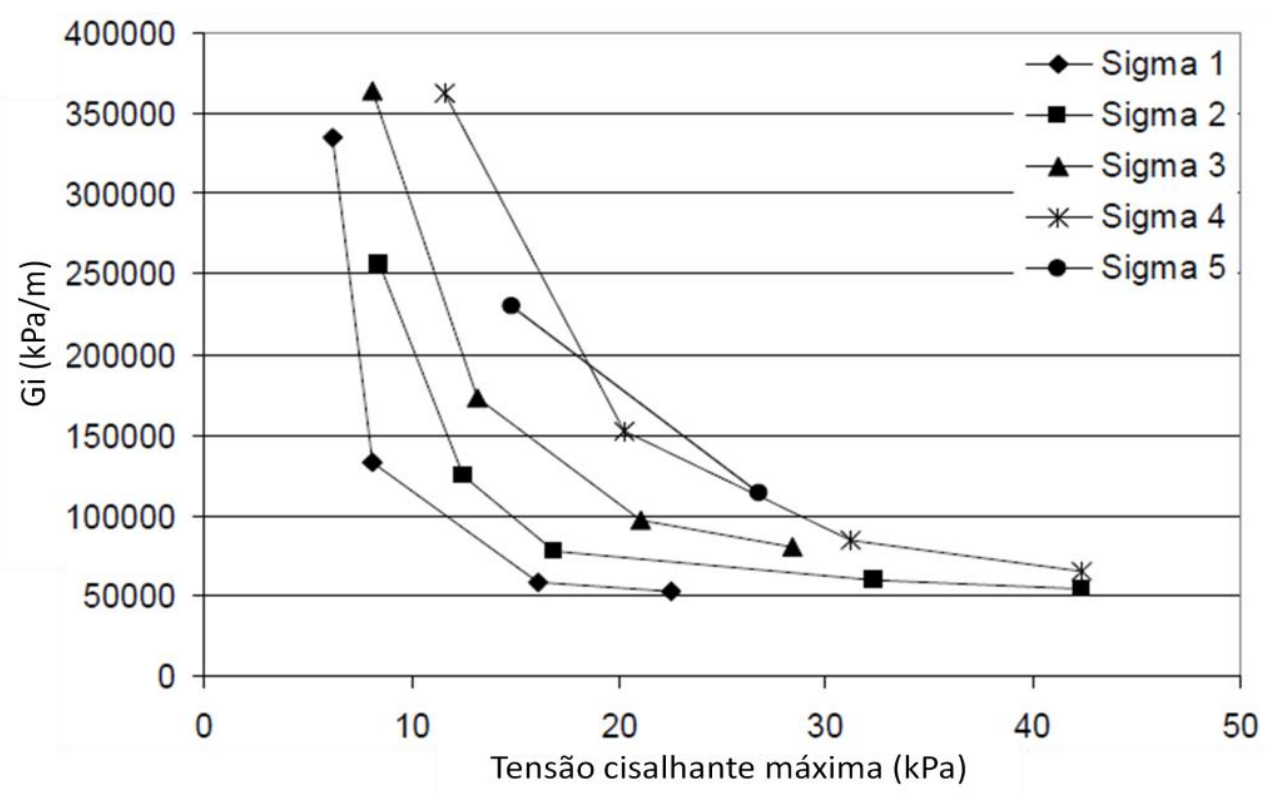

Figura 2.34 - Módulo de cisalhamento de interface versus tensão cisalhante para vários confinamentos, geogrelha na direção longitudinal (Adaptado de CUELHO e PERKINS, 2005). 
Na pesquisa de Holley (2009), assim como Perkins (2004) foram utilizados corpos de prova de aproximadamente $490 \mathrm{~mm}$ de largura por cerca de $80 \mathrm{~mm}$ de comprimento ancorado. Foram comparados os ensaios de ciclagem em amostras com duas $(80 \mathrm{~mm})$ e três aberturas (cerca de $120 \mathrm{~mm}$ ) e optou-se por utilizar amostras de duas aberturas, considerando-se que apresentava uma melhor precisão e comportamento mais estável, sendo que com três aberturas (material mais longo) era acumulada deformação ao longo da ciclagem. 


\section{Materiais e Métodos}

Nesta pesquisa foi aprimorado o equipamento denominado Caixa de Arrancamento e Ciclagem situado no Laboratório de Geossintéticos da Escola de Engenharia de São Carlos EESC-USP, que realiza ensaios de arrancamento e cíclico em materiais de reforço confinados em grandes dimensões. Este capítulo descreve as modificações realizadas no equipamento, seu funcionamento, capacidade de realização de ensaios assim como calibrações e verificações realizadas. São elucidados ainda os materiais de reforço (geossintéticos), os materiais que representam os meios reforçados (solos) bem como os resultados obtidos nos ensaios.

\subsection{Equipamento}

Foi aprimorado nesta pesquisa o equipamento desenvolvido por Teixeira (2003) para a finalidade de ensaios de arrancamento e posteriormente modificado por García (2011) que possibilitou a realização de ensaios cíclicos em reforços.

Inicialmente o equipamento funcionava através de um motor elétrico com potência de $1 / 2 \mathrm{CV}$, ligado em série por meio de correias a um redutor de rotação. Este era ligado em série a um parafuso com rosca infinita, que tracionava a garra com a amostra, promovendo o arrancamento com velocidade de cerca de $4,6 \mathrm{~mm} / \mathrm{min}$, e com capacidade de tração de $50 \mathrm{KN}$. Tal sistema de tração foi posteriormente substituído por um sistema hidráulico que passou a apresentar capacidade de tração e compressão, permitindo que a garra retorne à posição após a tração. O novo sistema permitiu ainda a aplicação da força de arrancamento com velocidades programáveis e maiores do que as alcançadas com o sistema mecânico, permitindo a 
realização de ensaios cíclicos e ainda com capacidade de tração de $50 \mathrm{KN}$. O esquema da Figura 3.1 mostra os diversos sistemas que compõe o equipamento.

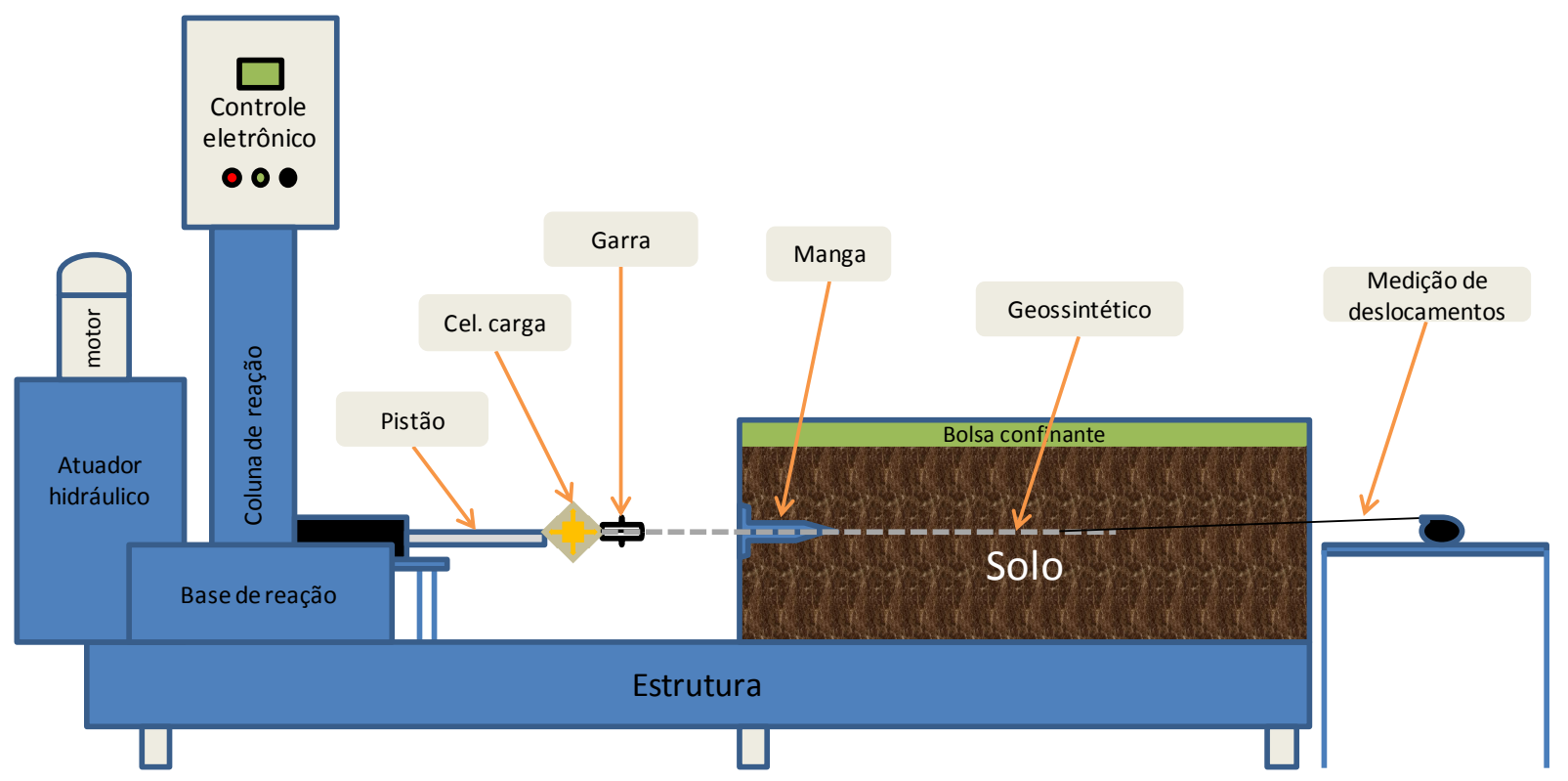

Figura 3.1 - Esquema de funcionamento do equipamento de arrancamento e ensaios cíclicos.

O equipamento possui dimensões acima das mínimas necessárias de acordo com as recomendações da ASTM D 7499 (2009) para a realização de ensaios de arrancamento e ciclagem. Suas dimensões são 1,50 $m$ de comprimento, 0,70 $m$ de largura e 0,48 $m$ de altura, ilustrado na Figura 3.2 a seguir.

A utilização do equipamento depende de testes e calibrações que foram realizadas com a variação das diversas configurações possíveis, onde se pôde alterar a tensão confinante, a compacidade do solo, o comprimento e largura da amostra, e ainda parâmetros referentes às configurações das ciclagens e arrancamento realizadas pelo equipamento. 


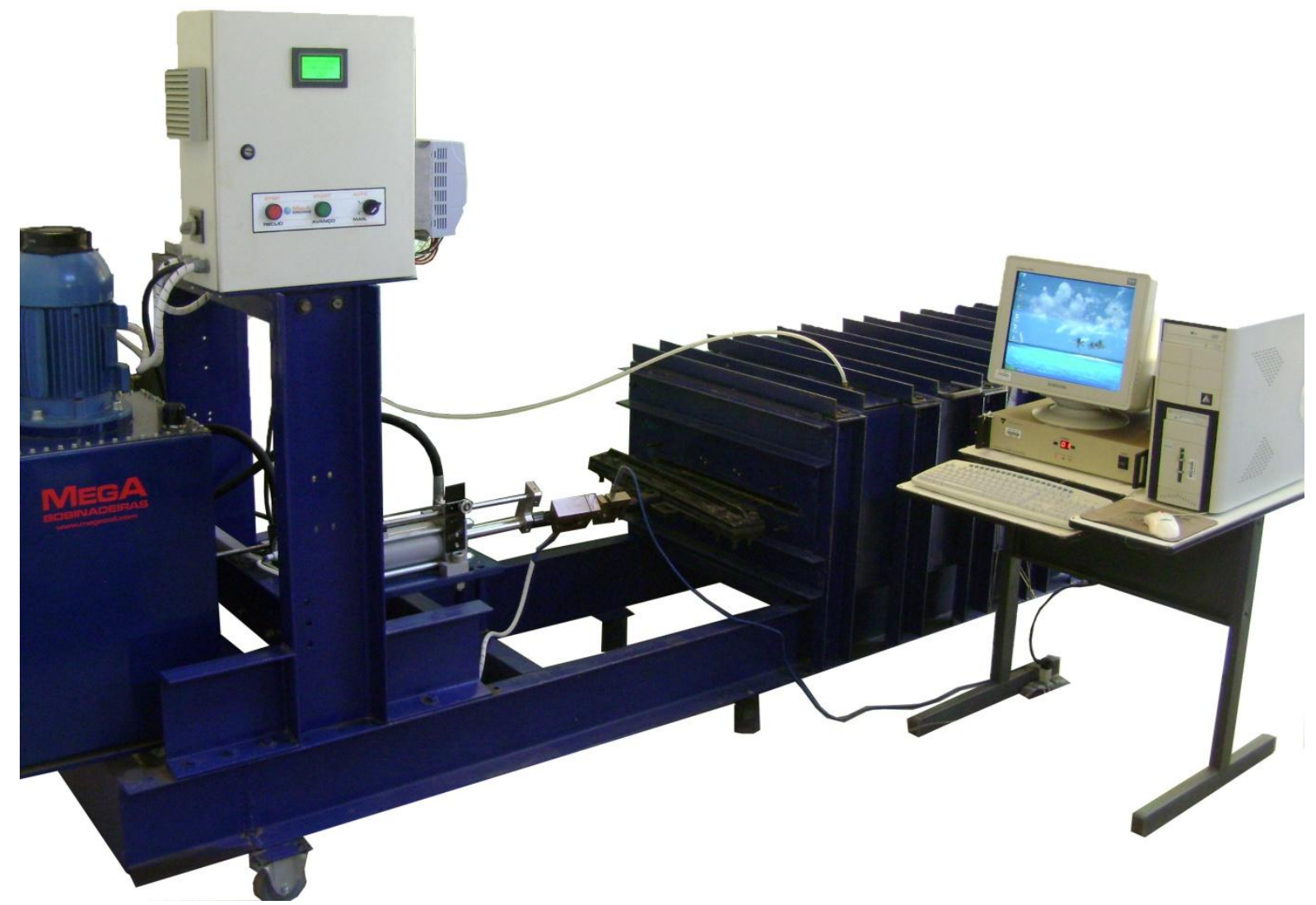

Figura 3.2 - Equipamento com caixa de arrancamento e ciclagem confinada de reforços.

As configurações do equipamento apresentam parâmetros passíveis de modificação e que resultam em modificações substanciais de comportamento quanto à ciclagem. Entre estes parâmetros estão à variação da velocidade do motor, a faixa de valores de carregamento máximo e mínimo do ciclo, o tempo de pulso programado, a vazão de óleo para o movimento do pistão e a pressão do óleo do sistema.

\subsubsection{Tensão confinante}

A caixa de ensaios utilizada apresenta dimensões que não possibilitariam a aplicação de tensões confinantes semelhantes às encontradas em campo, sendo assim, é utilizada uma bolsa de ar comprimido ilustrada na Figura 3.3 a seguir com capacidade de aplicação de até 
$160 \mathrm{kPa}$ de sobrecarga no solo abaixo, representando a função de acréscimo de tensão confinante.

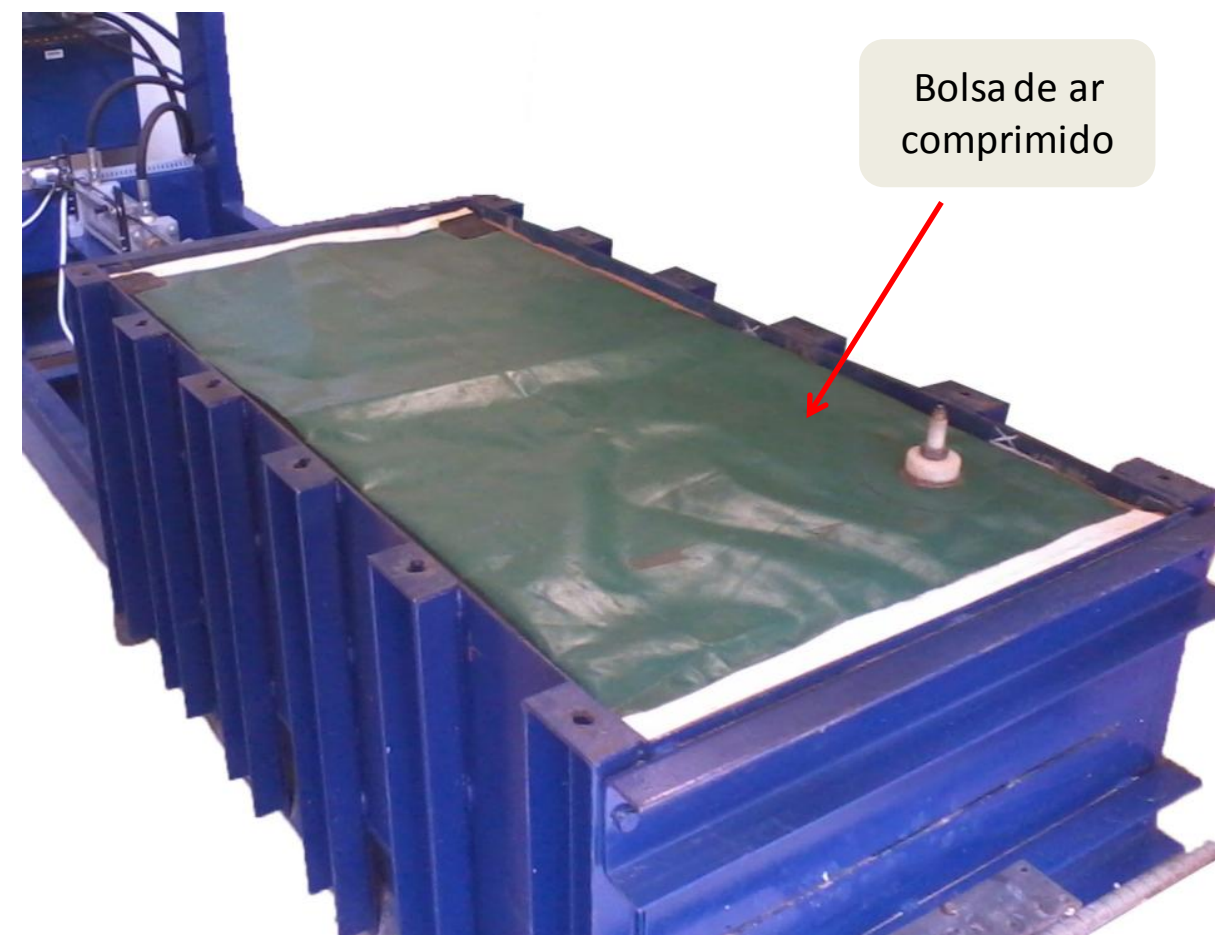

Figura 3.3 - Bolsa de ar para aplicação de tensão confinante.

\subsubsection{Carregamento cisalhante}

A tensão horizontal de cisalhamento que é aplicada sobre o reforço provém de um pistão hidráulico fixado no equipamento externamente à caixa de ensaios confinados. O pistão hidráulico é alimentado por uma bomba elétrica que confere ao conjunto capacidade de tração no reforço de até cinco toneladas.

O sistema de controle de velocidade da bomba, assim como os sistemas que controlam o deslocamento do pistão e carga aplicada funcionam por meio de um controlador lógico programável (CLP), onde são inseridos dados de velocidade desejada do pistão, carga de cisalhamento e configurações do pulso de carregamento cíclico. 
O controle de carregamento do CLP utiliza sistemas de aquisição de deslocamento do pistão e carga cisalhante individuais ao sistema de aquisição de dados utilizado no ensaio. Para o controle do movimento do pistão é utilizado um transdutor de deslocamento acoplado ao equipamento. O sistema de controle de cargas cisalhantes imposto pelo CLP é controlado através de uma célula de carga acoplada à frente do pistão hidráulico, como ilustrado na Figura 3.4 a seguir.

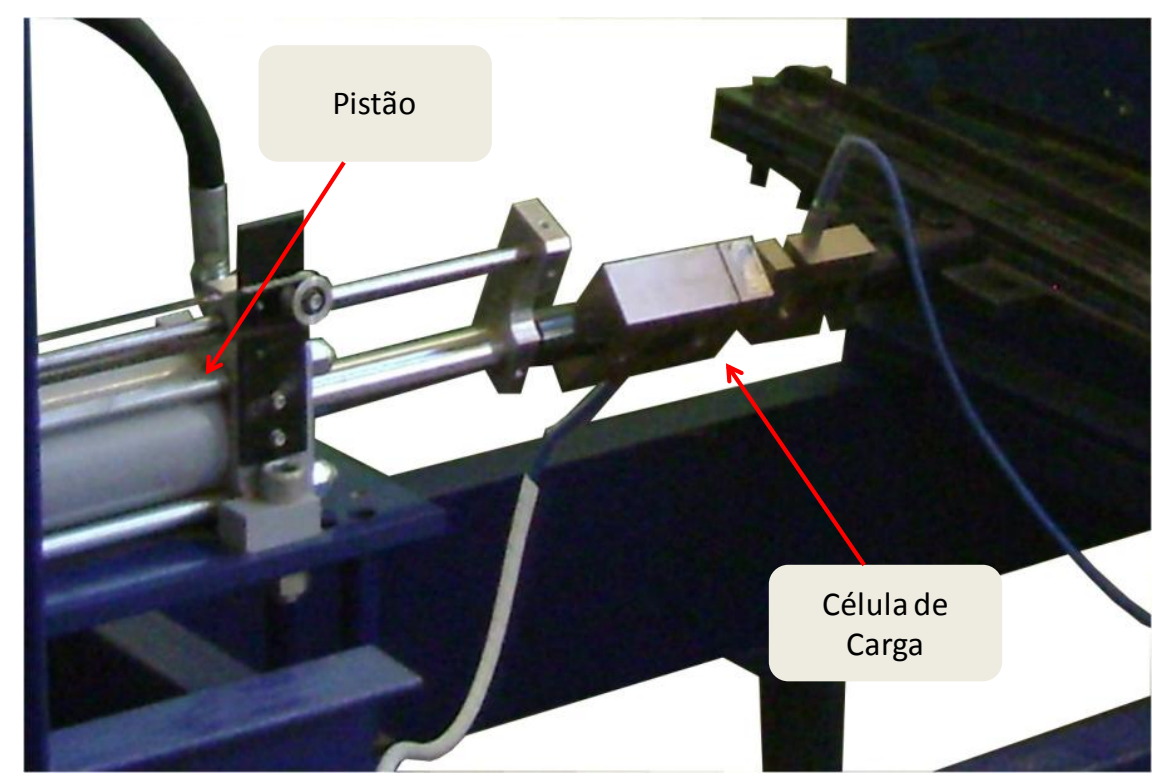

Figura 3.4 - Célula de carga acoplada ao pistão hidráulico para carregamento cisalhante.

\subsubsection{Modificações no equipamento}

Foram realizadas modificações no sistema de garras do equipamento, modificações na programação do CLP, modificações do sistema de leitura de deslocamentos com a aquisição de novos sensores e modificações no sistema hidráulico do atuador, com a adição de uma válvula de controle de fluxo para o pistão, detalhadas a seguir. 


\subsubsection{Garras de fixação da amostra}

As garras de fixação da amostra utilizadas no equipamento foram modificadas com a inserção de nervuras de reforços ao longo de suas laterais de fixação (Figura 3.5 a seguir) com o intuito de impedir a flexão da garra com o aperto de parafusos de fixação em suas laterais. Isto imobiliza a amostra por toda sua extensão e impede escorregamentos diferenciais da amostra no interior da garra.

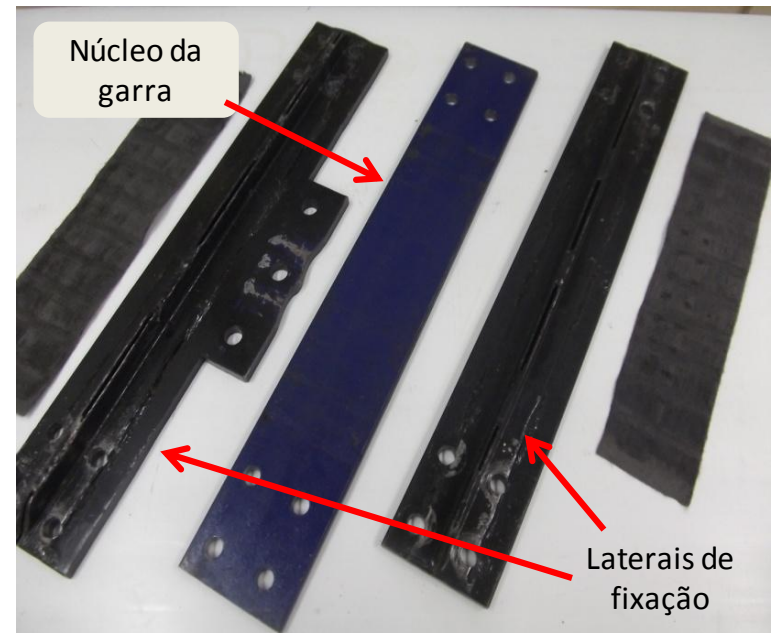

(a)

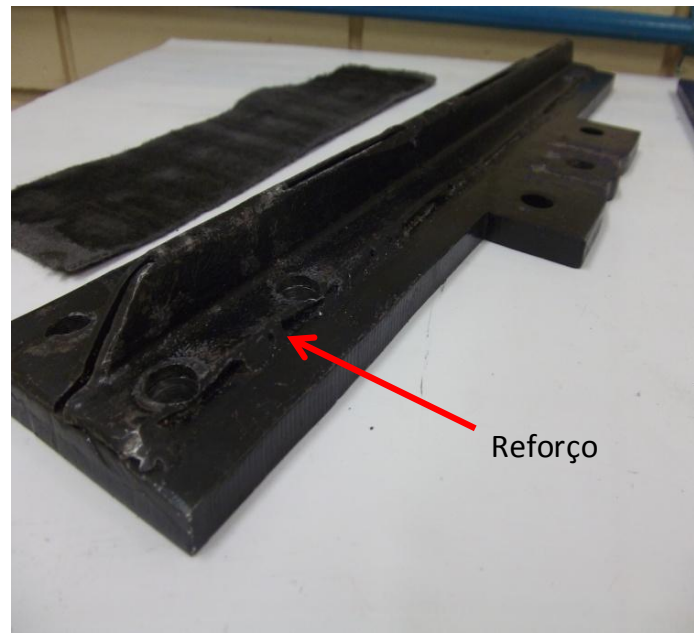

(b)

Figura 3.5 - (a) Laterais de fixação reforçadas e núcleo (parte central) da garra; (b) detalhe da nervura de reforço.

\subsubsection{Controlador Lógico Programável}

As modificações no sistema CLP (Controlador Lógico Programável) foram realizadas através de reprogramação do sistema, fornecendo confiabilidade e segurança ao ensaio.

Visando a segurança do ensaio e a integridade do equipamento foram inseridas programações de parada do ensaio para fins de curso pré-determinados e ajustáveis, impedindo que o curso da garra arranque o material totalmente, impossibilitando uma possível exumação, e impedindo que a garra colida na parede frontal da caixa de ensaios, destruindo a célula de carga, a garra e/ou a caixa de ensaios. 
Outra programação de segurança adicionada foi a parada da garra ao final do ensaio. Isto faz com que a garra pare e permaneça no local da aplicação da última carga, impedindo o choque com a parede da caixa ou o arrancamento do material.

Com o objetivo de analisar o ensaio em tempo real foram adicionados mostradores de carga e deslocamento da garra instantâneos e ainda um mostrador com contador de ciclos, que proporciona noções de tempo de duração de ensaio (Figura 3.6(a) a seguir).

Após a inserção das programações de segurança e de mostradores em tempo real foi feita uma remodelagem das áreas de trabalho de entradas de dados, buscando divisões de parâmetros como programações de deslocamento, de carga, de ciclagem e de controle do CLP em áreas de trabalho distintas (Figura 3.6(b) a seguir).

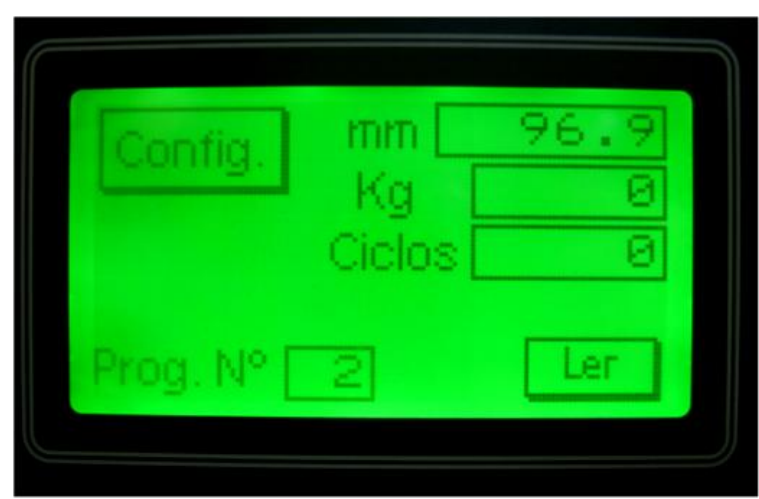

(a)

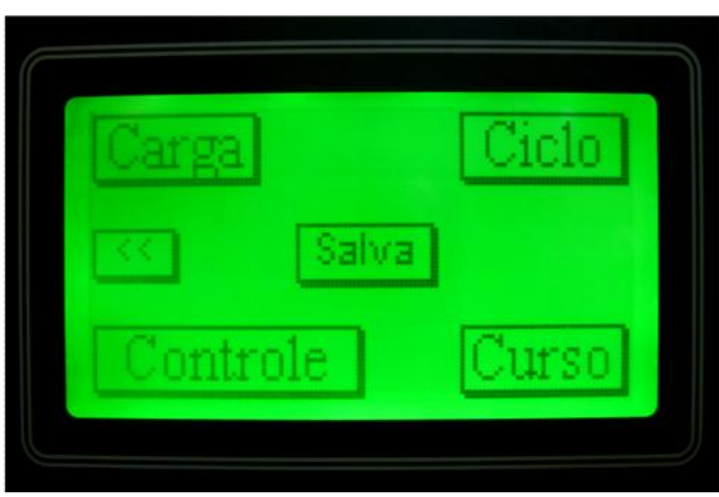

(b)

Figura 3.6 - (a) Área de trabalho inicial; (b) Área de trabalho de programação ("Config.") de ensaios.

Após as configurações diversas de ciclagem, carga, curso e controle há opção de salvar as configurações inseridas em até 99 posições distintas, não necessitando a reconfiguração destes parâmetros novamente.

Entre as configurações ajustáveis do controlador (CLP) do atuador estão:

- Controle de cargas máxima e mínima de ciclagem, variando entre 1 e $5000 \mathrm{~kg}$, com precisão de $1 \mathrm{~kg}$. 
- Velocidade de deslocamento do pistão (traciona a amostra), variando de 1 a 53 $\mathrm{mm} / \mathrm{s}$ com precisão de $1 \mathrm{~mm} / \mathrm{s}$.

- Tempo de carga máxima do ciclo (pulso), com precisão de 0,01 s.

- Tempo de carga mínima do ciclo (assentamento ou descanso), com precisão de $0,01 s$.

- Número de ciclos realizado, com precisão de 1 ciclo completo.

- Deslocamento mínimo da garra, baseado em um deslocamento atual ajustável, com precisão de $0,1 \mathrm{~mm}$.

- Deslocamento máximo da garra, baseado em um deslocamento atual ajustável, com precisão de $0,1 \mathrm{~mm}$.

- Opção de parada ou não, na carga de pulso ou de assentamento (maior ou menor respectivamente).

- Opção de atuação automática do CLP alterando a velocidade do pistão conforme o tempo de ciclagem pré-determinada. Ocorre alteração da velocidade de deslocamento do pistão conforme o dispositivo registra o tempo de ciclagem fora do especificado, buscando automaticamente velocidades de deslocamento do pistão que alcancem o tempo de ciclo pré-determinado.

- Opção de salvar as configurações detalhadas acima, de cargas, ciclos, deslocamentos e programações em 99 posições diferentes, evitando a reprogramação a cada ensaio.

Tal gama de ajustes confere ao equipamento inúmeras opções de ensaios e configurações de ciclagens, mostrando grande versatilidade do equipamento e podendo ser utilizado para vários fins de ciclagens com vários materiais diferentes.

\subsubsection{Sensores de Deslocamento}

Foram incorporados a este ensaio cíclico seis transdutores de deslocamento que funcionam a base de potenciômetro (Figura 3.7 (b) e (c)) e apresentam precisão de 0,001 mm ou $1 \mu \mathrm{m}$, fixados a uma mesa (Figura 3.7 (a)) e posicionados à frente da abertura da parte traseira da caixa de ensaios. A mesa a qual os sensores foram fixados foi construída especialmente para este fim e apresenta regulagem de altura nos pés, podendo ser modificada a altura e a inclinação da mesa para uma fixação precisa dos sensores à frente da abertura da caixa de ensaios. 
Estes sensores foram implementados visando um aumento de precisão nas medições de deslocamentos de pequenas magnitudes (cerca de 0,001 $\mathrm{mm}$ ) que ocorrem em certos tipos de reforços.

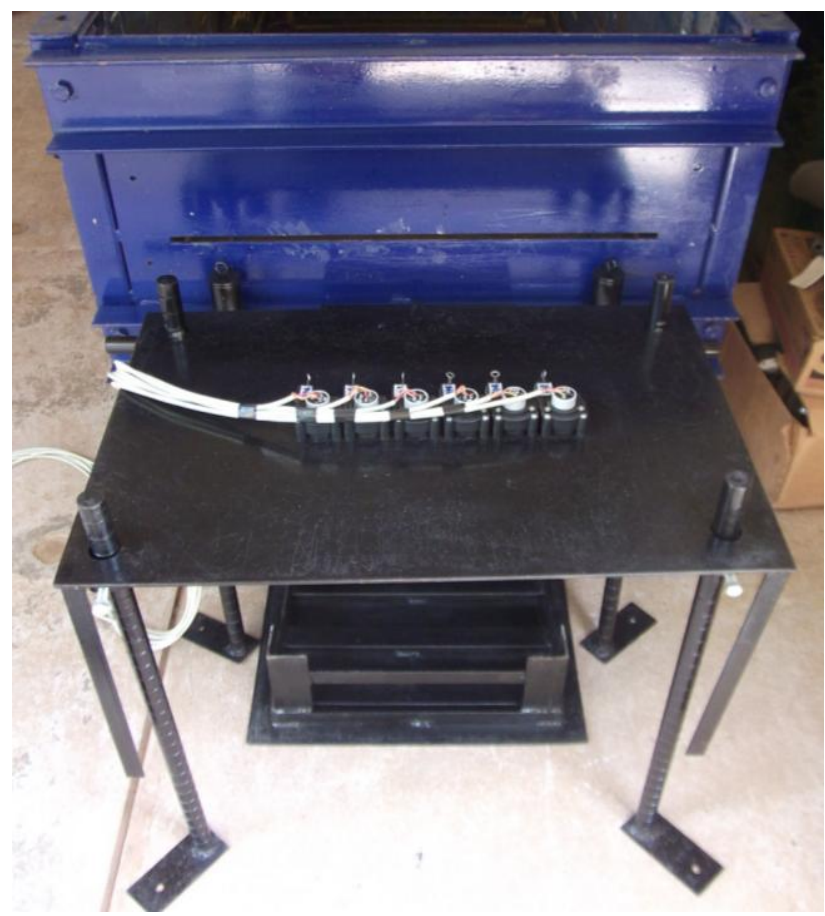

(a)

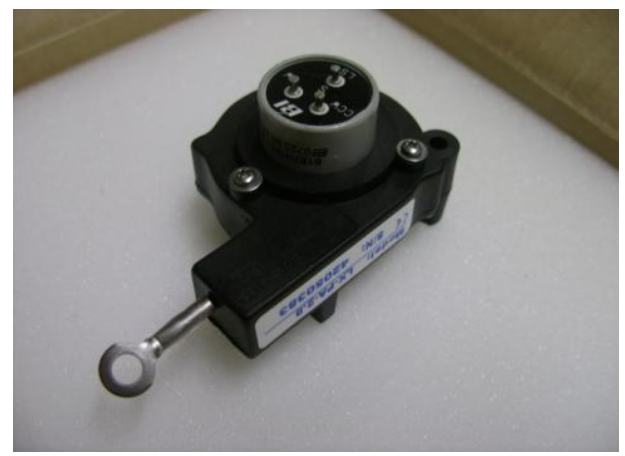

(b)

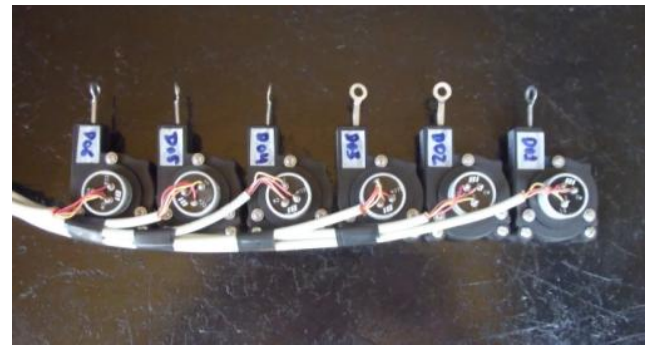

(c)

Figura 3.7 - (a) Mesa de fixação dos sensores; (b) Detalhe do sensor; (c) Posicionamento dos sensores na mesa.

\subsubsection{Válvula de controle de fluxo}

Para a correta realização dos ensaios de arrancamento e o aumento da precisão dos ensaios cíclicos foi implementada uma válvula de controle de fluxo de óleo entre a bomba hidráulica e o pistão de aplicação de força.

A válvula de duplo controle de vazão instalada (Figura 3.8) apresenta controle de vazão ajustável desde vazão total (fluxo livre enviado pela bomba) até vazão nula (estrangulamento total da vazão enviada pela bomba), podendo-se controlar a vazão individualmente para o avanço e recuo do pistão de aplicação de carga. A válvula confere um ajuste "fino" da vazão do óleo, o que no ensaio representa uma aplicação de carga máxima e 
mínima mais sutil e precisa, melhorando a velocidade de aplicação de carga do ciclo e aumentando a precisão da carga aplicada, melhorando ainda o controle de velocidade do ensaio de arrancamento.

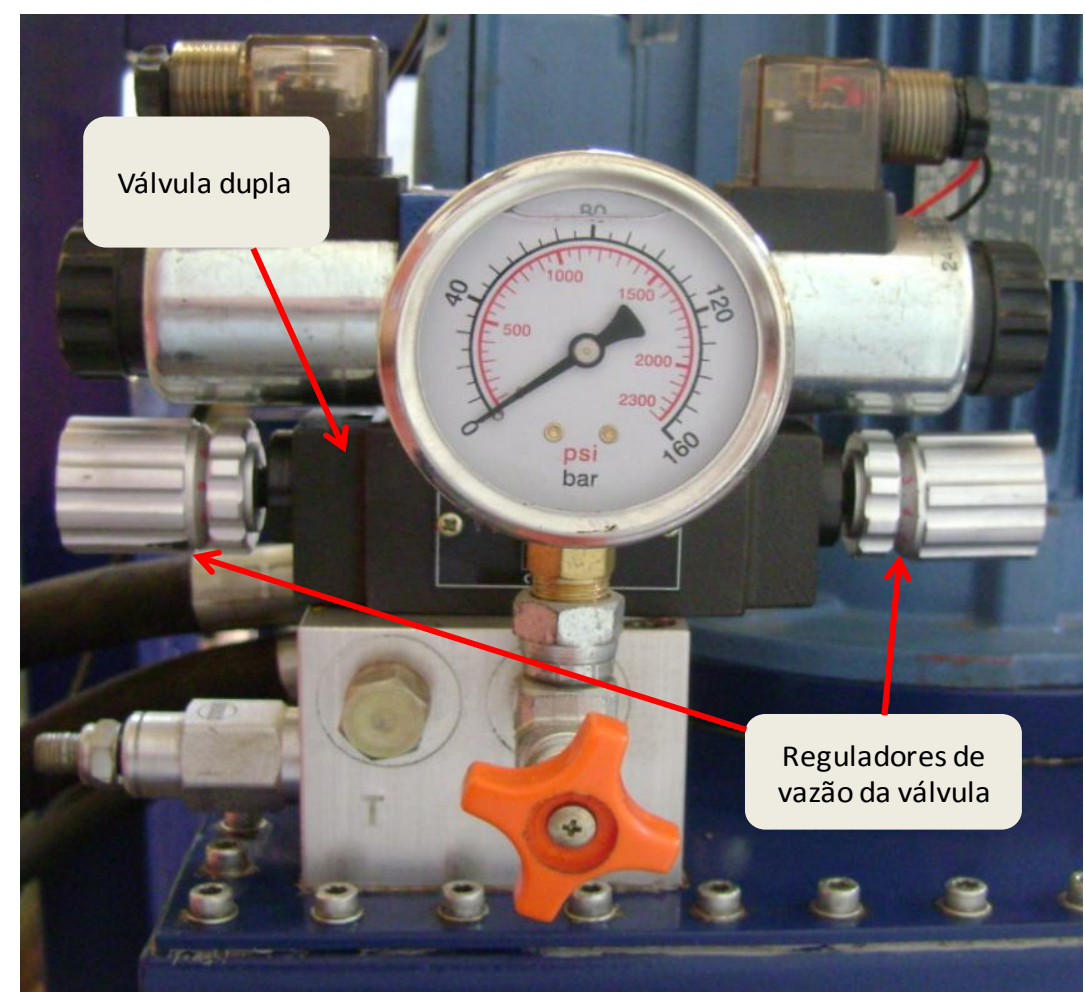

Figura 3.8 - Válvula dupla controladora de fluxo de óleo.

\subsubsection{Calibrações dos sensores}

Para a realização dos ensaios foram utilizados sensores para medição dos deslocamentos pontuais no reforço, sensores para quantificar a tensão total em pontos do meio confinante, medição das cargas aplicadas por meio do pistão e ainda deslocamento da garra que fixa o corpo de prova.

A fim de garantir a acurácia e precisão das aquisições realizadas, todos os sensores foram calibrados e/ou tiveram suas calibrações conferidas. Os sistemas de calibração e conferência são descritos a seguir. 


\subsubsection{Células de carga}

Foram utilizadas duas células de carga para medida da força de tração aplicada pelo pistão no reforço, sendo uma célula de carga de cinco toneladas com resolução de um quilograma para controle de carregamentos aplicados pelo CLP e outra célula de carga ligada em série à primeira, com capacidade de duas toneladas e resolução de 0,2 quilogramas responsável pela obtenção de dados do sistema de aquisição.

Para a calibração das células de carga utilizadas no ensaio, foi utilizada uma terceira célula de carga calibrada em uma máquina universal de ensaios, acoplada em série às duas células do equipamento e submetidas a um carregamento conhecido in loco, visando uma calibração que considere os esforços de peso próprio da garra, flexão do eixo do pistão assim como características físicas do equipamento.

\subsubsection{Células de tensão total}

Foram utilizadas células de tensão total com capacidade de $200 \mathrm{kPa}$ da fabricante Kyowa ${ }^{\circledR}$ calibradas in loco através de uma tensão conhecida aplicada por uma bolsa de ar e mensurada por meio de manômetros analógicos.

Os sensores foram dispostos como ilustrado na Figura 3.9 a seguir e posicionados a uma distância de quatro $\mathrm{cm}$ abaixo da bolsa de ar a fim de evitar contato direto com a superfície da bolsa. A pequena quantidade de solo acima dos sensores apresenta peso desprezível, ficando dentro da faixa de resolução dos mesmos.

Ao final de cada ensaio de arrancamento e ciclagem as células de tensão total eram testadas em um equipamento portátil denominado P3 (Model P3 Strain Indicator and Recorder), onde se verificava a integridade da fiação e de resposta dos sensores, assim como a estabilização do sinal dos mesmos. 


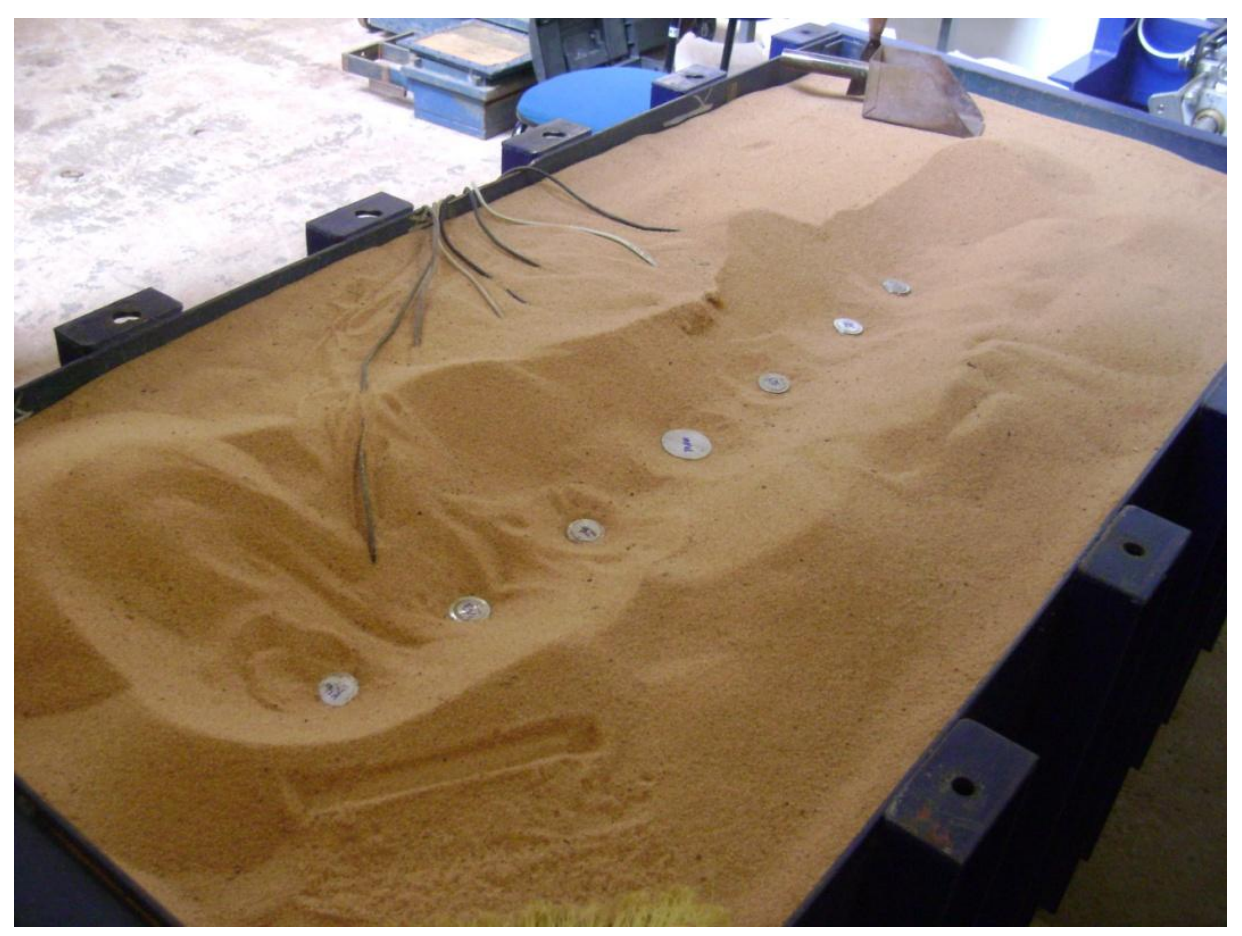

Figura 3.9 - Posicionamento das células de tensão total para calibração.

\subsubsection{Sensores de deslocamento LVDT's}

Foram utilizados sensores de deslocamento LVDT's com faixa de leitura de $100 \mathrm{~mm}$ e resolução de 0,01 mm. Os LVDT's foram calibrados comparando-se as leituras com relógios analógicos com resolução de 0,01 mm. A fixação dos LVDT's em conjunto com os relógios analógicos é ilustrada na Figura 3.10 a seguir.

Ao final dos ensaios os sensores LVDT's tiveram sua calibração conferida, comprovando que a calibração se manteve durante todas as caixas ensaiadas. 


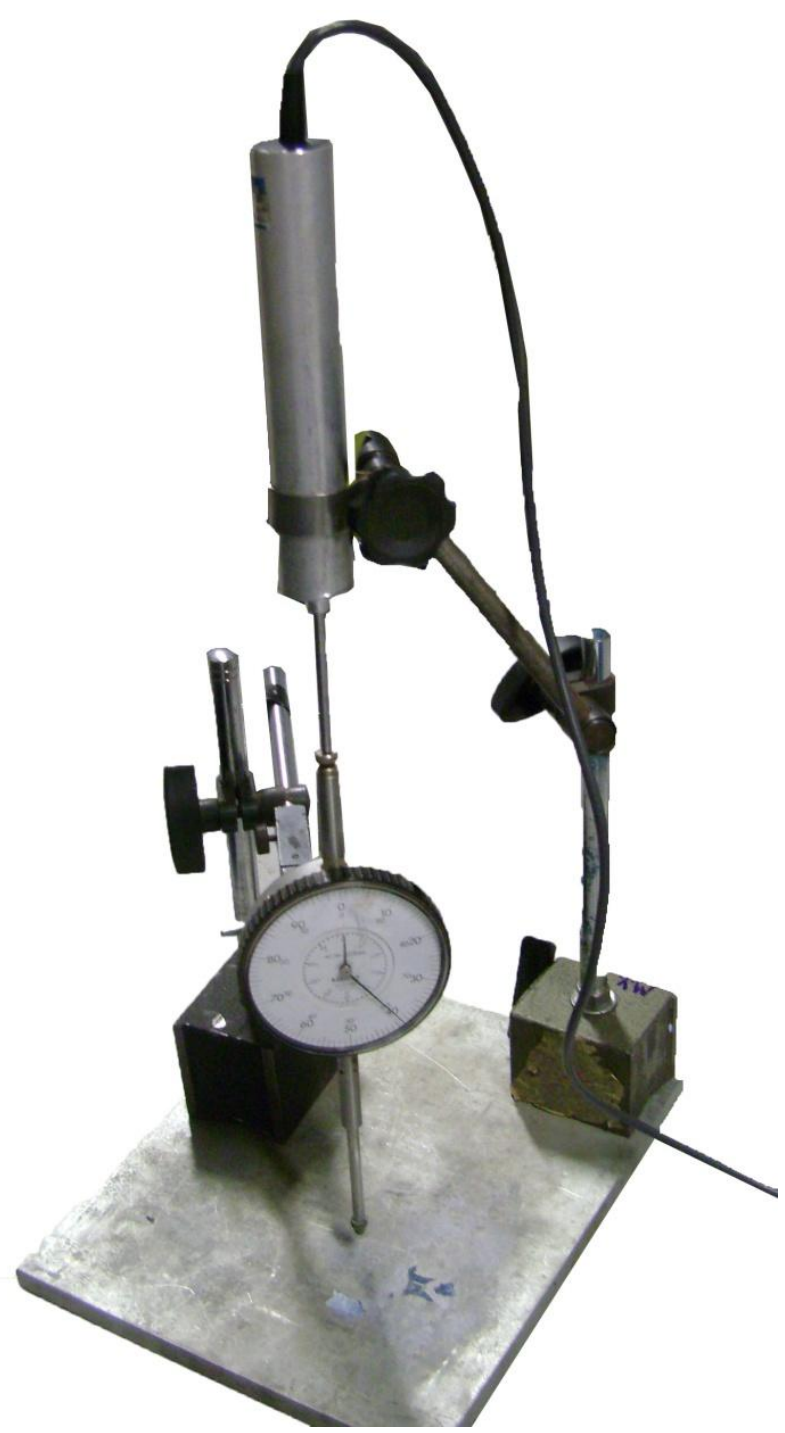

Figura 3.10 - Disposição do LVDT durante calibração.

\subsubsection{Transdutores de deslocamento}

Foram adquiridos transdutores de deslocamento LX-PA 2.8 da empresa UniMeasure ${ }^{\circledR}$ que vieram com informações precisas a respeito da calibração original de fábrica. Durante a utilização dos sensores houve uma aferição da calibração original, comparando-se os valores de deslocamento dos sensores com os sensores LVDT's já calibrados, cuja calibração foi descrita anteriormente. Para a fixação dos transdutores de deslocamento foi desenvolvida uma plataforma com altura ajustável, visando um alinhamento preciso dos sensores na frente da abertura da caixa. 
Ao final dos ensaios os sensores tiveram sua calibração conferida por meio de um paquímetro digital com precisão de $0,01 \mathrm{~mm}$ e mostraram que não houve perda de calibração dos mesmos, assegurando confiança de leituras aos ensaios.

\subsubsection{Calibrações do Controlador Lógico Programável e equipamento}

A seguir são descritos os sistemas utilizados para caracterizar o comportamento do equipamento para diversas configurações e ajustes de ensaios cíclicos e de arrancamento, assim como as configurações mais apropriadas utilizadas nos ensaios.

\subsubsection{Velocidades variáveis}

Parte da calibração do equipamento se deu variando-se a velocidade do pistão hidráulico responsável por aplicar a força cisalhante que traciona o reforço. A velocidade do pistão é controlada por meio de um inversor de frequência instalado junto ao CLP (Controlador Lógico Programável) do equipamento, podendo-se programar a velocidade do pistão de 1 a 53 milímetros por segundo.

A seguir é apresentado o gráfico (Figura 3.11) formado a partir de ensaio com configurações de tensão confinante de $70 \mathrm{kPa}$ na bolsa de ar, velocidade de ciclo de 0,2 segundos de pulso e 0,8 segundos de descanso entre os pulsos, carga de ciclagem constante programada com intervalo entre 50 e $130 \mathrm{~kg}$ (Carga de assentamento de $50 \mathrm{~kg}$ e carga máxima da ciclagem de $130 \mathrm{~kg}$ ), pressão hidráulica de 30 bar e válvula reguladora de fluxo totalmente aberta. Para a caracterização do comportamento quanto à variação da velocidade do pistão, foi variada apenas a velocidade de 3 a $15 \mathrm{~mm} / \mathrm{s}$ com acréscimos de $2 \mathrm{~mm} / \mathrm{s}$.

O aumento da velocidade do pistão confere diminuição do tempo do ciclo e um aumento na amplitude das cargas do ensaio, significando menor controle de carregamento aplicado, tendo em vista que as cargas desejadas eram entre 50 e $130 \mathrm{~kg}$. 


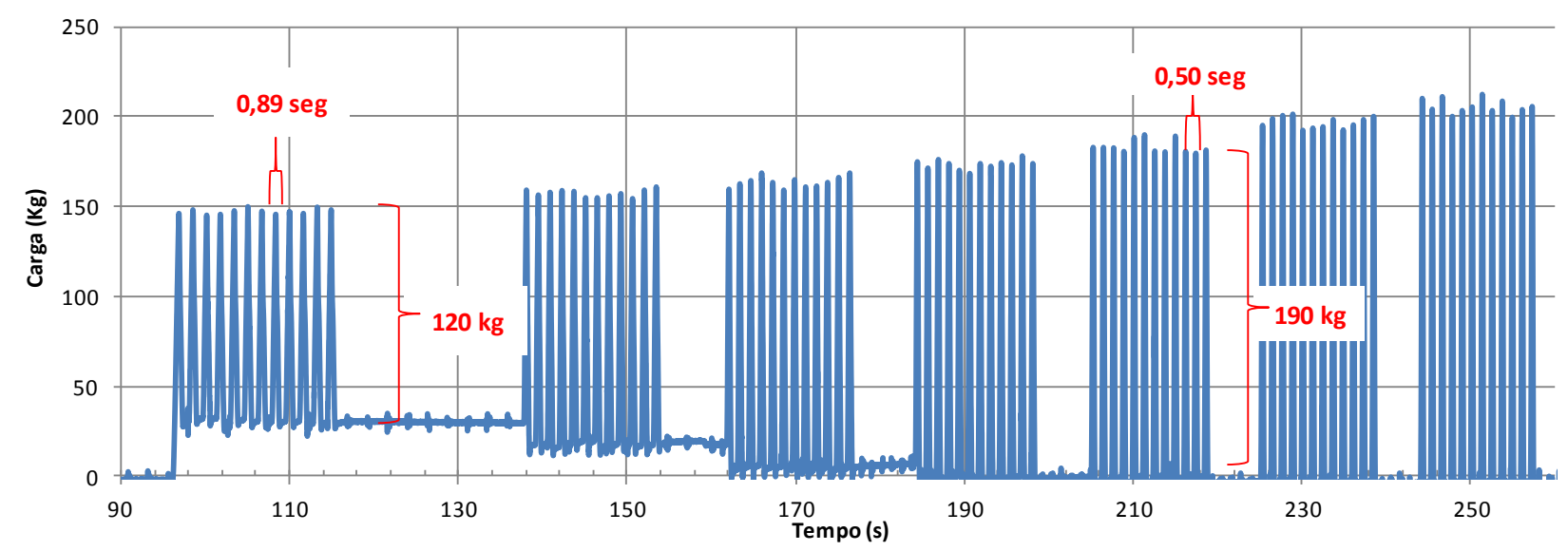

Figura 3.11 - Ciclagem com velocidade do pistão variável.

No início do ensaio foi obtido tempo de ciclagem de 0,9 s para uma variação de 120 kg. Já no término da calibração pode-se obter ganho de velocidade de ciclagem, passando esta acerca de $0,5 s$, porém com um menor controle de amplitude de cargas, passando esta para aproximadamente $190 \mathrm{~kg}$.

Este tipo de teste permitiu concluir que a variação da velocidade do pistão permite um ganho de velocidade de tempo de ciclagem com um proporcional ganho de amplitude de cargas.

\subsubsection{Variação da carga de ciclagem}

Uma das variações de configurações do equipamento foi referente à amplitude de cargas aplicadas ao reforço durante a ciclagem. Tal parâmetro é variado através de programação na CLP do equipamento e pode ser configurado durante o ensaio com precisão de quilogramas.

Para este teste, o equipamento foi configurado com tensão confinante de $70 \mathrm{kPa}$ na bolsa de ar, velocidade de ciclo de 0,2 segundos de pulso e 0,8 segundos de descanso entre os pulsos, velocidade do pistão de $10 \mathrm{~mm} / \mathrm{s}$, pressão hidráulica de $30 \mathrm{bar}$ no equipamento e 
válvula reguladora de fluxo totalmente aberta. Para a caracterização do comportamento quanto à variação da carga de ciclagem foi aplicada uma variação de cargas inicial de $50 \mathrm{~kg}$ de assentamento e $130 \mathrm{~kg}$ de carga máxima. Tal carga foi variada diminuindo-se a carga máxima de $130 \mathrm{~kg}$ até $100 \mathrm{~kg}$ em patamares de $10 \mathrm{~kg}$, e foi variada a carga de assentamento aumentando-se a carga de $50 \mathrm{~kg}$ até $90 \mathrm{~kg}$ em patamares de $10 \mathrm{~kg}$. Inicialmente a amplitude de cargas era de $80 \mathrm{~kg}$ e ao final do ensaio alcançou $10 \mathrm{~kg}$, representando-se a resposta do equipamento através da Figura 3.12 a seguir.

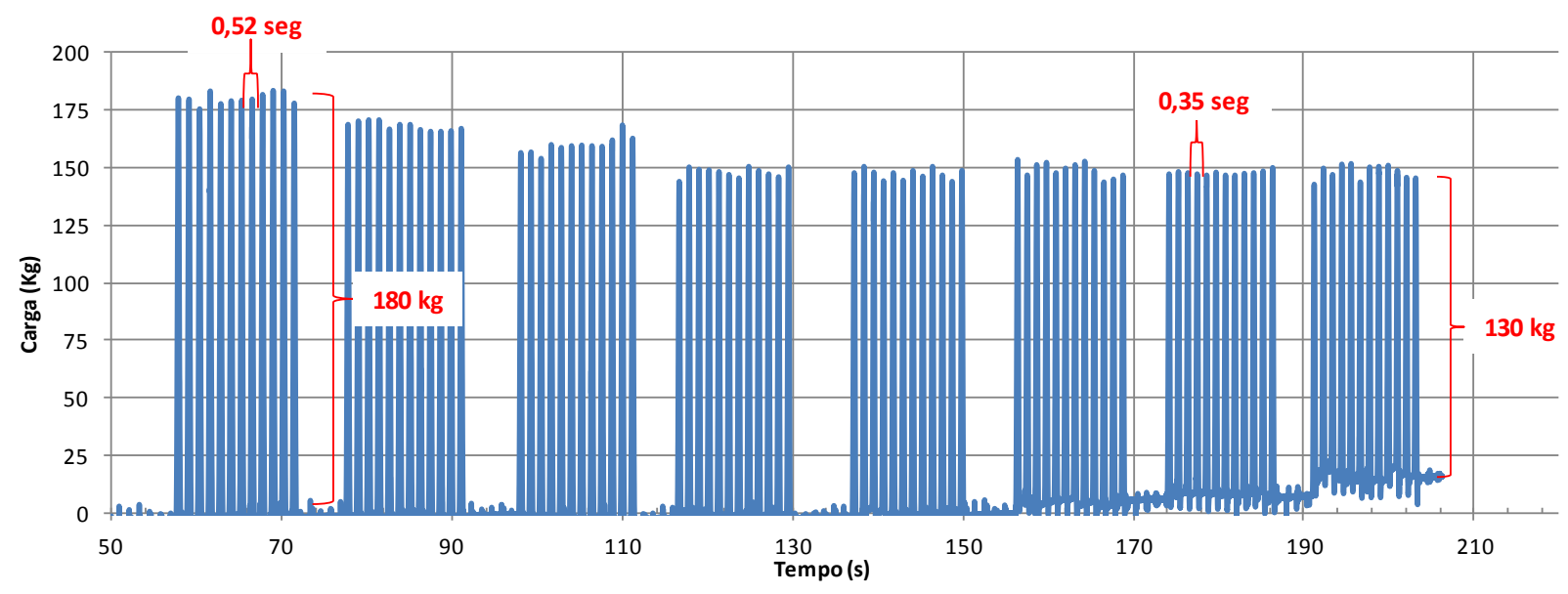

Figura 3.12 - Variação de amplitude de carga.

A variação das cargas para a programação de amplitude inicial de $80 \mathrm{~kg}$ apresentou amplitude real de $180 \mathrm{~kg}$, e ao final das variações foram observadas para as amplitudes programadas de $10 \mathrm{~kg}$, amplitudes reais de $130 \mathrm{~kg}$, representando uma variação de cerca de 30 \% na amplitude real. Analisando-se ainda a variação dos tempos dos ciclos alterando-se apenas a configuração das cargas, foi obtido tempo inicial de ciclo de $0,52 s$ e com a amplitude do ciclo menor ocorreu diminuição do tempo do ciclo para $0,35 \mathrm{~s}$. Tal variação de diminuição do tempo de ciclagem se dá, pois com uma amplitude menor de cargas o equipamento apresenta deslocamento menor do pistão, logo, apresenta resposta mecânica mais rápida. 
A variação da resposta do equipamento à faixa de carregamento programada depende de vários fatores como a rigidez do material, a deformação total da amostra desde a carga de assentamento até alcançar a carga máxima, e está ligada ainda à capacidade mecânica e eletrônica do sistema de aquisição, que é limitada à resposta máxima de 12 variações por segundo da válvula inversora de direção, e limitado à capacidade do sistema CLP. Quando o tempo de ciclagem é consideravelmente maior, o equipamento apresenta resposta ao carregamento com grande precisão em relação aos valores de entrada na programação do equipamento, variando na casa de quilogramas.

\subsubsection{Variação da pressão do óleo}

Foi aferido o comportamento do equipamento quando variada a pressão de óleo do sistema. A variação da pressão hidráulica se dá através de fechamento mecânico de uma válvula situada na parte superior da bomba hidráulica. A pressão do sistema é conferida através de um manômetro analógico situado juntamente à válvula de pressão e esta pode ser modificada e conferida a qualquer instante, mesmo durante o ensaio.

Para caracterizar o comportamento referente à pressão do óleo, foram mantidas a tensão confinante de $70 \mathrm{kPa}$ na bolsa de ar, a velocidade de ciclo de 0,2 segundos de pulso e 0,8 segundos de descanso entre os pulsos, a carga de assentamento e máxima de 50 e $130 \mathrm{~kg}$ respectivamente, a velocidade do pistão de $10 \mathrm{~mm} / \mathrm{s}$ e a válvula reguladora de fluxo totalmente aberta. A pressão do óleo inicial foi de 10 bar com um pico de 80 bar, variando-se de 10 em 10 bar. Este comportamento é exibido na Figura 3.13 a seguir.

A variação de pressão de óleo do equipamento foi de 70 bar e ao longo desta variação não foi observada mudança significativa na carga e no tempo de ciclagem. Vale ressaltar que para a utilização do equipamento para ensaios de arrancamento deve ser utilizada uma pressão de óleo acima de 40 bar para se conseguir força suficiente para o arrancamento. 


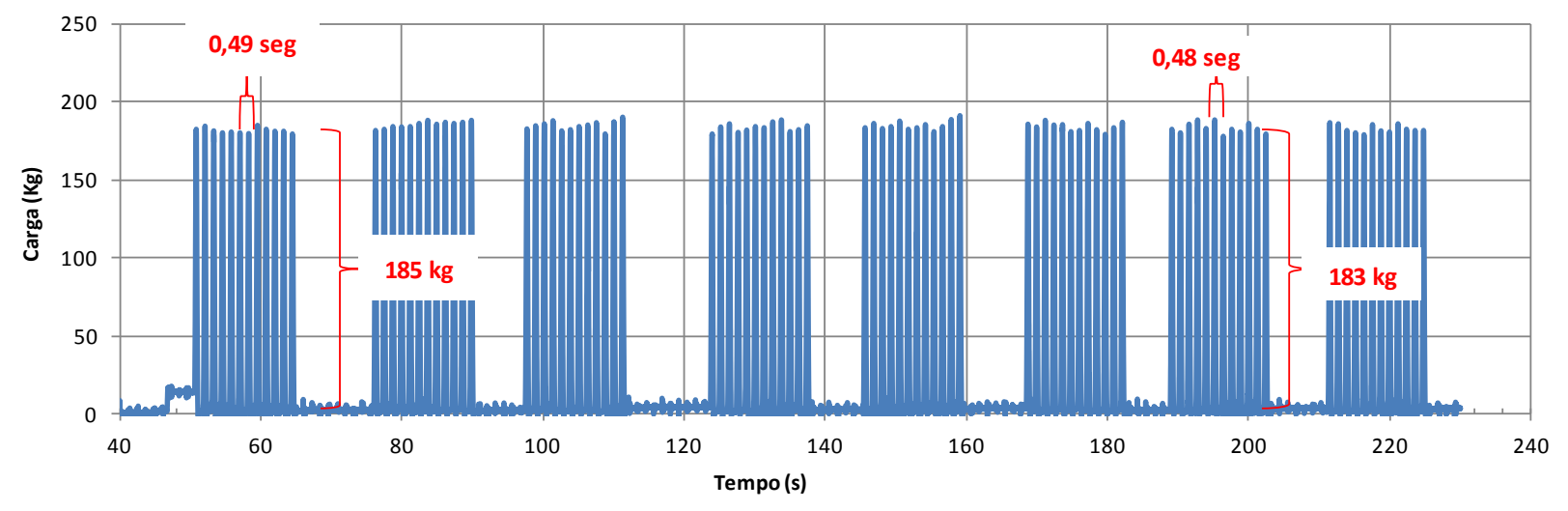

Figura 3.13 - Variação da pressão do óleo.

Já para o caso de utilização de ensaios cíclicos deve ser utilizada uma pressão de cerca de 40 bar, pois acima desta o equipamento sobrecarrega os sistemas adjacentes.

\subsubsection{Variação do fechamento das válvulas}

Foi adicionada uma válvula dupla de controle de fluxo de óleo do pistão com a finalidade de auxiliar no ajuste preciso de carregamentos durante a ciclagem e ainda no ensaio de arrancamento, diminuindo a velocidade do arrancamento para velocidades usualmente utilizadas.

A válvula dupla apresenta controle do fluxo de óleo para as câmaras de extensão e de contração do pistão. Fica situada acima da válvula de controle de pressão sobre a bomba hidráulica, e permite variações de fluxo desde fluxo livre até o estanque total de uma ou das duas câmaras do cilindro, podendo ser manuseada também durante o ensaio.

Para uma caracterização do funcionamento da válvula o equipamento foi mantido com uma tensão confinante de $70 \mathrm{kPa}$ na bolsa de ar, velocidade de ciclo de 0,2 segundos de pulso e 0,8 segundos de descanso entre os pulsos, velocidade do pistão de $10 \mathrm{~mm} / \mathrm{s}$, carga de 
assentamento e máxima da ciclagem entre 50 e $130 \mathrm{~kg}$ respectivamente e pressão do óleo de 30 bar.

Inicialmente as válvulas estavam completamente abertas e foram sendo fechadas até a diminuição do movimento do pistão, fornecendo comportamento como o representado na Figura 3.14 a seguir.

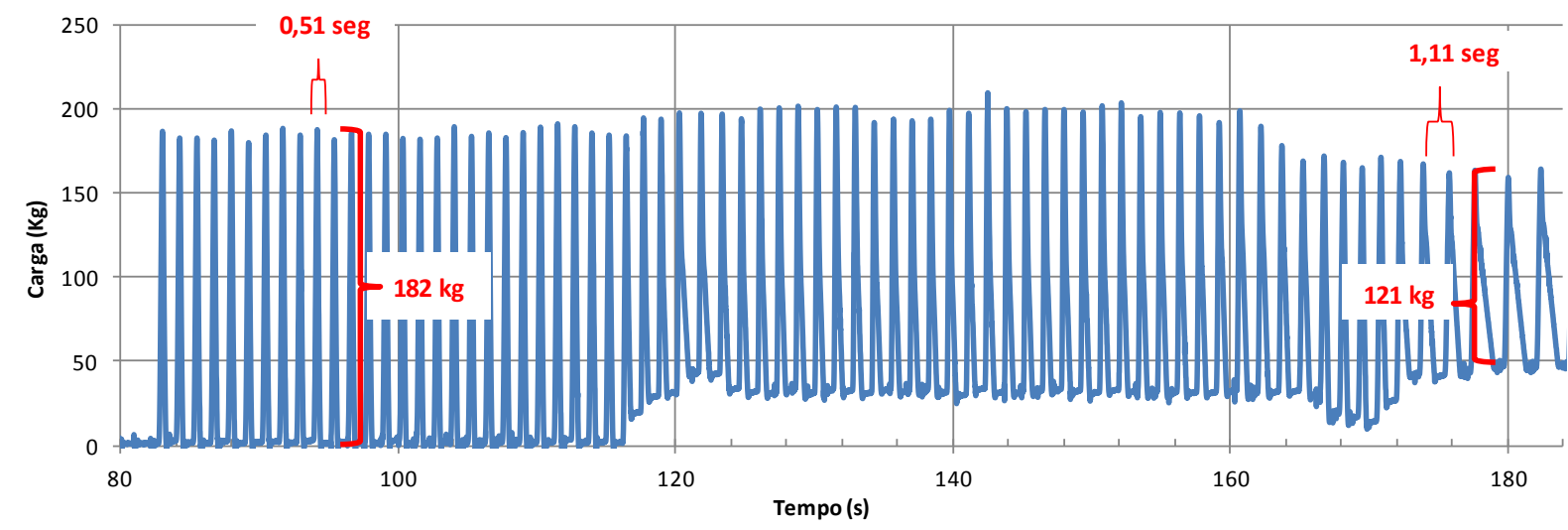

Figura 3.14 - Variação da vazão

O comportamento apresentado para esta variação do equipamento se mostra semelhante ao apresentado pela diminuição da velocidade do pistão, apresentando um aumento no tempo do ciclo de $0,51 s$ para $1,11 s$ com uma diminuição na amplitude dos carregamentos de $182 \mathrm{~kg}$ para $121 \mathrm{~kg}$. Tal comportamento ocorre devido ao estrangulamento progressivo do fluxo de óleo para as câmaras do pistão, diminuindo a velocidade do ciclo e consequentemente aumentando o controle sobre a aplicação dos carregamentos da ciclagem.

\subsubsection{Variações diversas}

Foi realizado um teste com combinações diversas de variações de velocidade do pistão, amplitudes de carga, diferentes pressões hidráulicas e fluxos hidráulicos buscando variações e comportamentos mais estáveis e precisos do equipamento. 
Este teste resultou em determinadas configurações que apresentam melhores respostas em relação a tempo de ciclagem e amplitudes de carregamentos, além de ter sido determinado o comportamento do equipamento em relação à continuidade e estabilidade dos parâmetros desejados sem sobrecarregar o sistema.

\subsubsection{Configurações de ensaio do equipamento}

Baseado nos diversos testes realizados no equipamento em relação ao comportamento da ciclagem quando eram variadas as diversas configurações eletrônicas e mecânicas possíveis, foram obtidos parâmetros de configurações que inicialmente foram utilizados nos ensaios cíclicos, descritos a seguir.

Parâmetros de configurações mecânicas utilizados:

- Pressão hidráulica utilizada nos ensaios cíclicos - 50 bar.

- Válvulas de controle de fluxo hidráulico apenas para controle de "ajuste fino", permanecendo com cerca de $70 \%$ aberta.

- Fixação dos LVDT's com hastes com cerca de 70 \% comprimidas.

- Fixação dos Transdutores de deslocamento no início da faixa de leitura (1 $\mathrm{mm}$ de $30 \mathrm{~mm}$ ).

Parâmetros de configurações eletrônicas utilizadas:

- Amplitudes de cargas cíclicas com cerca de $40 \mathrm{~kg}$ para mais e para menos, em relação à amplitude desejada.

- Velocidade de pulso de 0,4 segundos e descanso entre pulsos de 0,6 segundos, totalizando frequência de $1 \mathrm{hz}$.

- Velocidade do pistão variável de acordo com o nível de carregamento, ancoragem e amplitude desejada, variando entre 20 e $37 \mathrm{~mm} / \mathrm{s}$.

Para o ensaio de arrancamento a velocidade utilizada foi de $3,6 \mathrm{~mm} / \mathrm{min}$., equivalente a $1 \%$ de deformação do corpo de prova (entre a garra e o início da ancoragem no solo) por minuto, ficando próxima à utilizada anteriormente neste mesmo equipamento antes da modificação (TEIXEIRA, 2003). 
Os parâmetros de configurações referentes a calibrações eletrônicas e mecânicas utilizadas nos ensaios de arrancamento são descritos a seguir.

Parâmetros de configurações mecânicas utilizados:

- Pressão hidráulica utilizada nos arrancamentos - 80 bar.

- Válvulas de controle de fluxo hidráulico apenas para controle de "ajuste fino", permanecendo com cerca de $90 \%$ fechada.

- Fixação dos LVDT's com hastes com cerca de $70 \%$ comprimidas.

- Fixação dos Transdutores de deslocamento no início da faixa de leitura (1 mm de $30 \mathrm{~mm}$ ).

Parâmetros de configurações eletrônicas utilizadas:

- Amplitudes de cargas máximas de $1850 \mathrm{~kg}$, referente à resistência máxima da célula acoplada ao equipamento. (Carga utilizada com o intuito do arrancamento e não a ciclagem)

- Velocidade do pistão de $4 \mathrm{~mm} / \mathrm{s}$ (estrangulada mecanicamente).

\subsection{Reforço}

O reforço utilizado na pesquisa é uma geogrelha biaxial com resistência nominal de 40 $k N / m$ na direção longitudinal e $30 \mathrm{kN} / \mathrm{m}$ na direção transversal, constituída de filamentos de poliéster (PET) e recoberta com Policloreto de Vinila (PVC) mostrada na Figura 3.15 a seguir. A fim de facilitar a referência a este material o mesmo foi denominado apenas como "reforço". 


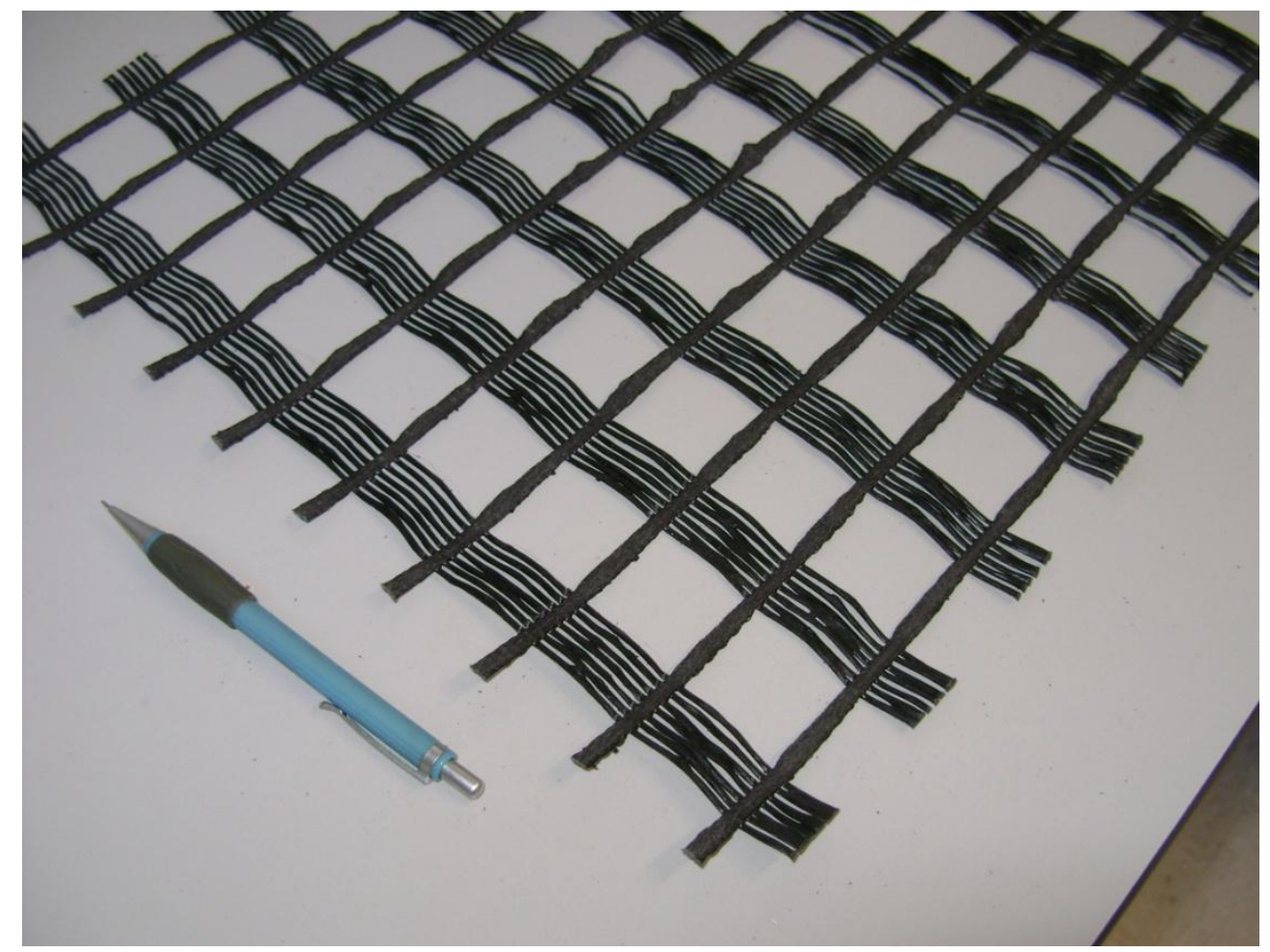

Figura 3.15 - Geogrelha utilizada na pesquisa.

Foram realizadas medições geométricas da geogrelha como aberturas, largura e espessura dos elementos, expressos na Tabela 3.1 a seguir.

Tabela 3.1 - Caracterização geométrica da geogrelha.

\begin{tabular}{|l|c|c|c|c|c|}
\cline { 2 - 6 } \multicolumn{1}{c|}{} & \multicolumn{3}{c|}{ Elementos $(\mathbf{m m})$} & \multicolumn{2}{c|}{ Área (\%) } \\
\cline { 2 - 6 } \multicolumn{1}{c|}{} & Largura & Espessura & Distância & Vazada & Preenchida \\
\hline Longitudinal & 5,26 & 1,02 & 32,35 & & \\
\hline Transversal & 20,43 & 1,43 & 33,35 & 0,51 & 0,49 \\
\hline
\end{tabular}

A tabela anterior mostra que cerca de metade da área da geogrelha é vazada, permitindo a interação entre as camadas de solo através do imbricamento do material confinante, que ocorre com a penetração e interligação de solo acima da geogrelha com o solo diretamente abaixo da mesma, intertravando os elementos do reforço no solo. 
A caracterização do material quanto à resistência e deformação foi realizada utilizando-se uma Máquina Universal de Ensaios Instron ${ }^{\circledR}$ com capacidade de 25 Toneladas e utilizando-se garras do tipo "rolete" para fixação da amostra, presente no Laboratório de Geossintéticos da Escola de Engenharia de São Carlos - EESC-USP, onde foram obtidos resultados referentes à tração de amostras da geogrelha como os exemplificados na Tabela 3.2 e Tabela 3.3, e Figura 3.16 e Figura 3.17 a seguir, utilizando-se como base a norma ASTM D $6637(2001)$.

Neste caso específico a amostragem de cinco corpos de prova apresentou resistência média à tração de 44,80 KN/m e com deformação média na ruptura de $11,15 \%$ na direção longitudinal.
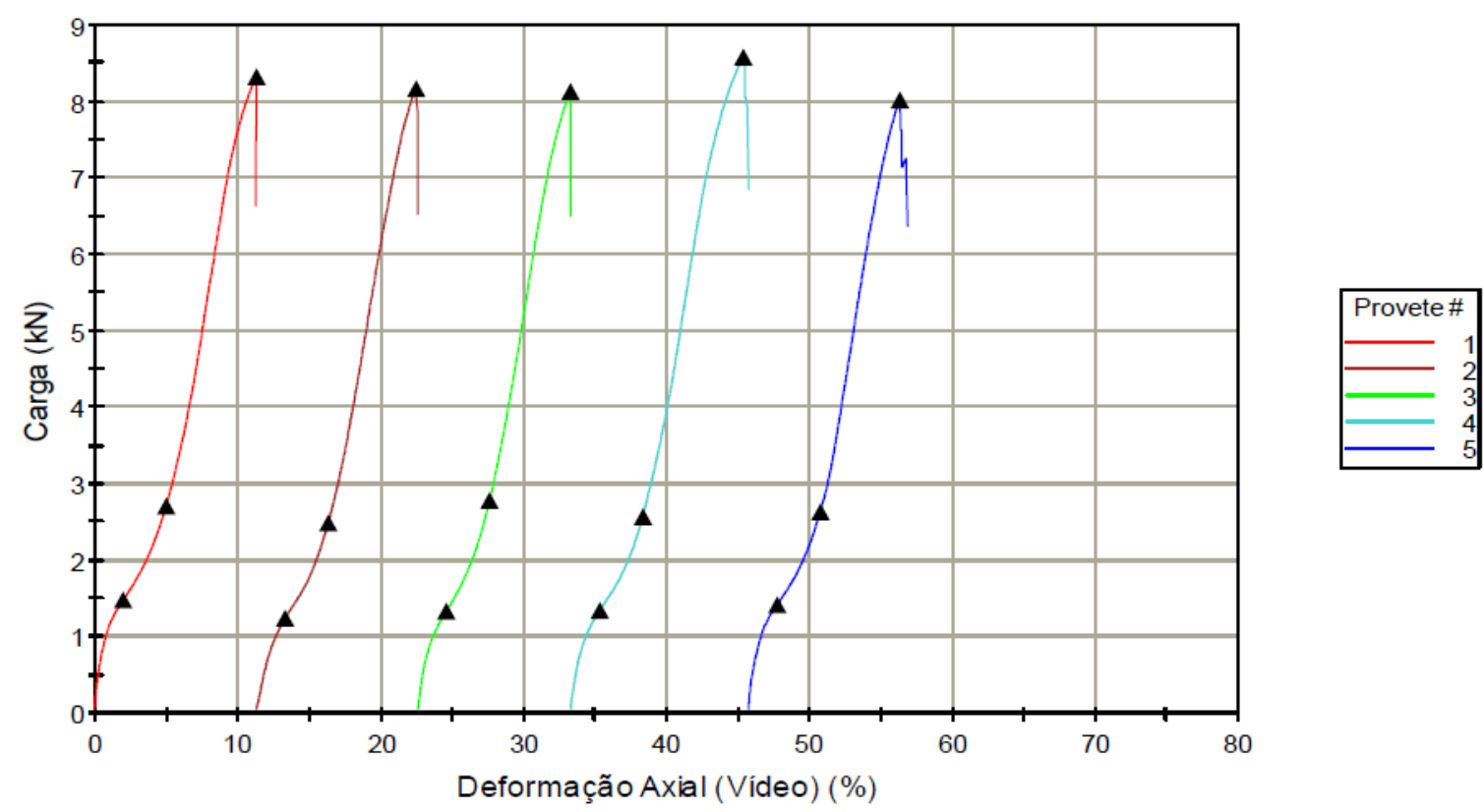

Figura 3.16 - Ensaio de tração em geogrelha, na direção longitudinal.

Os resultados mostrados na Tabela 3.2 a seguir apresentam, entre outros parâmetros, a força das geogrelhas ensaiadas a $2 \%$ e $5 \%$ de deformação na direção longitudinal. 
Tabela 3.2 - Resultados de ensaio de tração na geogrelha, na direção longitudinal.

\begin{tabular}{|c|c|c|c|c|c|}
\hline Parâmetro & Força & Def.Especif. & Força / Larg. & Força / Larg. & Força / Larg. \\
\hline Evento & Força Max. & Força Max. & Força Max. & $2 \%$ & $5 \%$ \\
\hline Unidade & $(\mathrm{kN})$ & $(\%)$ & $(\mathrm{kN} / \mathrm{m})$ & $(\mathrm{kN} / \mathrm{m})$ & $(\mathrm{kN} / \mathrm{m})$ \\
\hline
\end{tabular}

\begin{tabular}{|l|l|l|l|l|l|}
\hline CP 1 & 8,32 & 11,31 & 45,21 & 8,11 & 14,74 \\
\hline CP 2 & 8,17 & 11,13 & 44,39 & 6,79 & 13,53 \\
\hline CP 3 & 8,12 & 10,68 & 44,17 & 7,32 & 15,14 \\
\hline CP 4 & 8,58 & 12,06 & 46,65 & 7,35 & 13,99 \\
\hline CP 5 & 8,02 & 10,55 & 43,59 & 7,78 & 14,37 \\
\hline
\end{tabular}

\begin{tabular}{|c|c|c|c|c|c|}
\hline Média & 8,24 & $\mathbf{1 1 , 1 5}$ & $\mathbf{4 4 , 8 0}$ & 7,47 & 14,36 \\
\hline Coef.Var.(\%) & 2,64 & 5,36 & 2,64 & 6,68 & 4,36 \\
\hline
\end{tabular}

Na direção transversal foram obtidos resultados de resistência média à tração de 31,69 $K N / m$ e com deformação média na ruptura de $10,58 \%$, como ilustrado na Figura 3.17 a seguir.

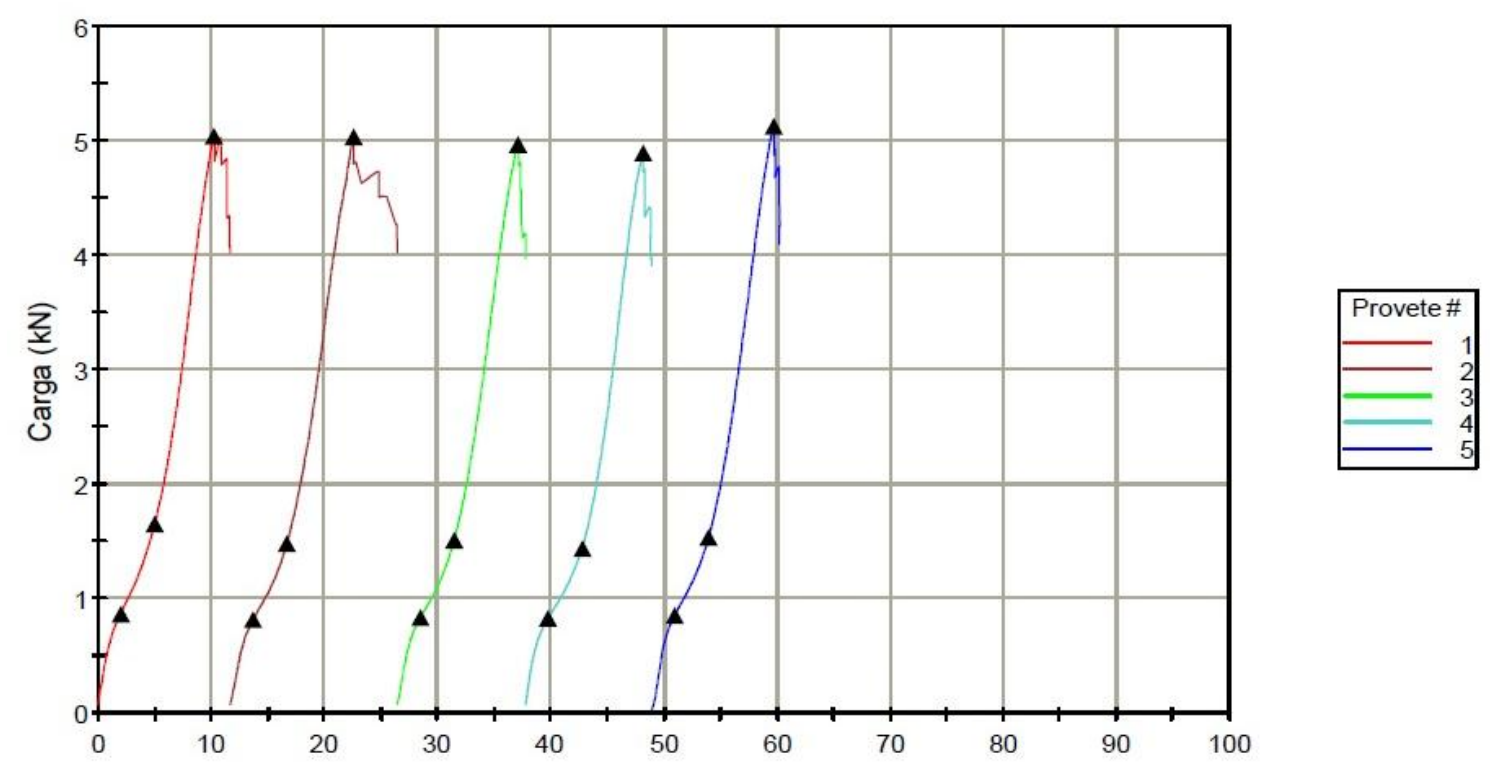

Figura 3.17 - Ensaio de tração em geogrelha, na direção transversal.

Os resultados mostrados na Tabela 3.3 a seguir apresentam, entre outros parâmetros, a força das geogrelhas ensaiadas a $2 \%$ e $5 \%$ de deformação na direção transversal. 
Tabela 3.3 - Resultados de ensaio de tração na geogrelha, na direção transversal.

\begin{tabular}{|c|c|c|c|c|c|}
\hline Parâmetro & Força & Def.Especif. & Força / Larg. & Força / Larg. & Força / Larg. \\
\hline Evento & Força Max. & Força Max. & Força Max. & $2 \%$ & $5 \%$ \\
\hline Unidade & $(\mathrm{kN})$ & $(\%)$ & $(\mathrm{kN} / \mathrm{m})$ & $(\mathrm{kN} / \mathrm{m})$ & $(\mathrm{kN} / \mathrm{m})$ \\
\hline
\end{tabular}

\begin{tabular}{|l|l|l|l|l|l|}
\hline CP 1 & 5,04 & 10,27 & 31,86 & 5,53 & 10,47 \\
\hline CP 2 & 5,03 & 10,85 & 31,82 & 5,20 & 9,37 \\
\hline CP 3 & 4,96 & 10,67 & 31,40 & 5,30 & 9,59 \\
\hline CP 4 & 4,89 & 10,38 & 30,94 & 5,29 & 9,14 \\
\hline CP 5 & 5,12 & 10,73 & 32,41 & 5,45 & 9,74 \\
\hline
\end{tabular}

\begin{tabular}{|c|c|c|c|c|c|}
\hline Média & 5,01 & $\mathbf{1 0 , 5 8}$ & $\mathbf{3 1 , 6 9}$ & 5,36 & 9,66 \\
\hline Coef.Var.(\%) & 1,73 & 2,31 & 1,73 & 2,44 & 5,23 \\
\hline
\end{tabular}

\subsection{Solos}

Os solos utilizados nesta pesquisa visam à representação de diferentes comportamentos de materiais com diferentes faixas granulométricas, que compõe a superfície natural de locais a serem pavimentados ou são utilizados como partes de sistemas de reforços. Os materiais utilizados na pesquisa são uma areia média, uma brita graduada simples faixa $\mathrm{C}$ do DER (ET-DE-P00/008, 2005) e um silte-argiloso, descritos a seguir. A fim de simplificar, estes materiais serão referenciados no restante do trabalho apenas como areia, brita e silte, respectivamente.

\subsubsection{Areia}

A areia é um material confinante muito utilizado para a caracterização de comportamentos de reforços de solo, tendo sido utilizada em pesquisas como García (2011), França (2011) e Maparagem (2011). A característica típica da areia relativamente uniforme faz com que este material apresente comportamento desejado quando utilizado como meio 
confinante para estudos de interação solo-reforço. A utilização deste material seco faz com que não haja coesão, e consequentemente não ocorram alterações de umidade e coesão durante o ensaio, logo, este material foi utilizado seco. Outra característica relevante deste material é o formato arredondado e o tamanho dos grãos, que não agridem o material de reforço quando compactado.

A areia utilizada na pesquisa é uma composição de areia de mineração proveniente da Mineração Jundu Ltda. situada no município de Descalvado, Estado de São Paulo, com um acréscimo de areia fina, visando um maior volume de material para o preenchimento da caixa de ensaios.

Após a mistura da areia de mineração com a areia fina foram obtidas as características delineadas na Tabela 3.4 a seguir.

Tabela 3.4 - Parâmetros da areia utilizada.

\begin{tabular}{|c|c|c|c|}
\hline \multirow{3}{*}{ Massa específica } & $v_{s}\left(k N / m^{3}\right)$ & 26,58 & ABNT 6508 \\
\hline & $V_{\text {máx }}\left(k N / m^{3}\right)$ & 17,39 & ABNT MB-3324 \\
\hline & $V_{\min }\left(\mathrm{kN} / \mathrm{m}^{3}\right)$ & 15,18 & ABNT MB-3328 \\
\hline \multirow{5}{*}{$\begin{array}{c}\text { Fração } \\
\text { granulométrica }\end{array}$} & Areia fina (\%) & 15 & \multirow{3}{*}{ ABNT MB 32} \\
\hline & Areia média (\%) & 55 & \\
\hline & Areia grossa (\%) & 30 & \\
\hline & Cc & 1,1 & \\
\hline & $\mathrm{Cu}$ & 2,4 & \\
\hline \multicolumn{2}{|c|}{ Classificação } & $\mathrm{SP}$ & SUCS \\
\hline
\end{tabular}

A curva granulométrica deste solo é ilustrada na Figura 3.18 a seguir, e mostra uma areia média, mal graduada. 


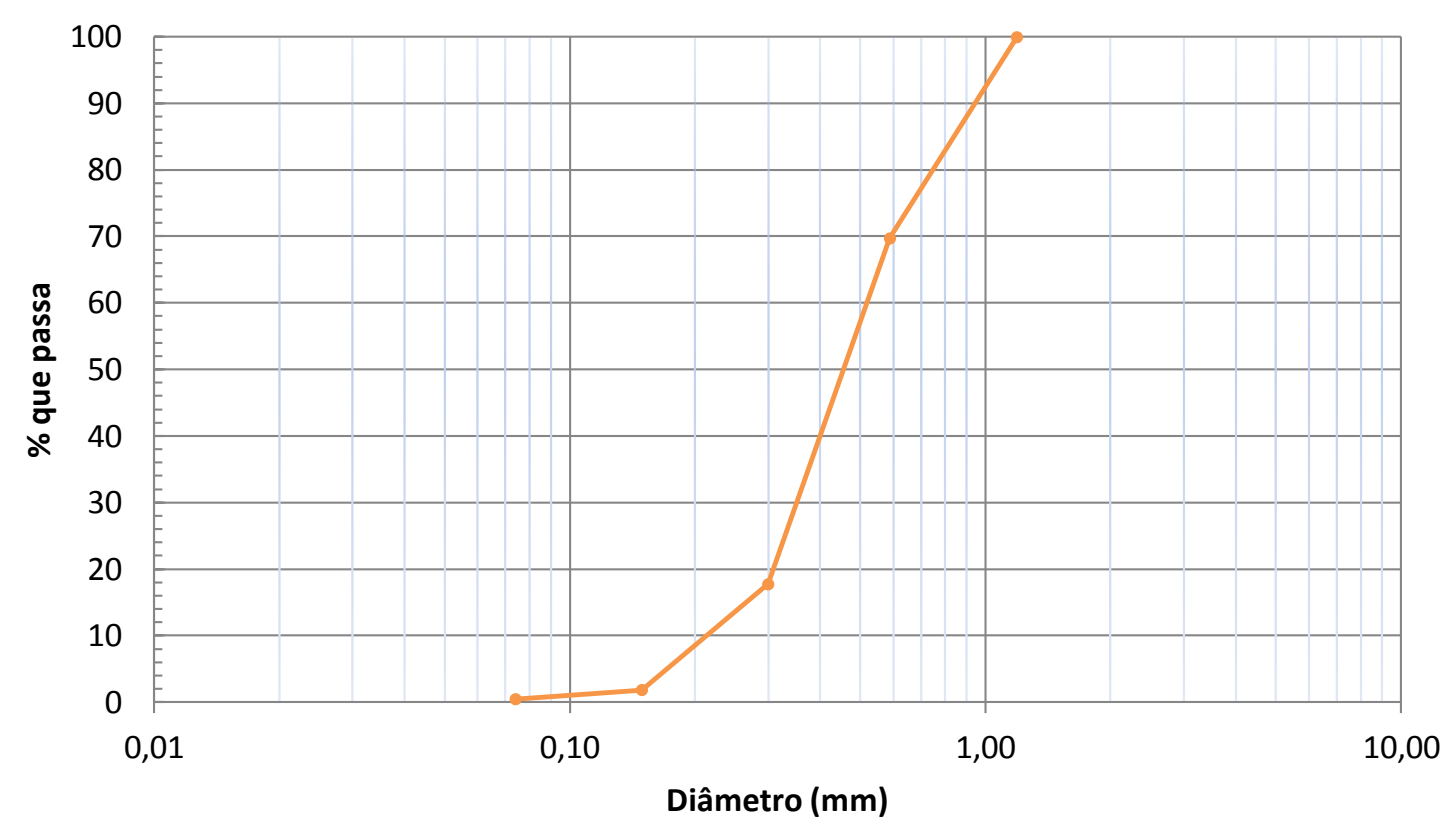

Figura 3.18 - Curva granulométrica da areia utilizada na pesquisa.

\subsubsection{Compactação da areia}

A areia foi ensaiada na condição seca ao ar, registrando-se valores de umidade inferiores a $1 \%$ em todos os ensaios.

A preparação do material se iniciou com sua exposição em local arejado até atingir teor de umidade baixo e constante. A areia era seca ao tempo até a umidade inferior a $1 \%$ e então era armazenada em bolsões de poliéster, que permaneciam em local seco e arejado para não haver alteração de umidade do material.

Antes de iniciar a montagem dos ensaios era feita uma calibração do método a ser utilizado na compactação. Inicialmente tentou-se utilizar uma placa vibratória para a compactação, porém, tal equipamento se mostrou inviável nesta caixa com dimensões relativamente pequenas. Por fim optou-se por utilizar para a areia um compactador manual tipo "soquete". O mesmo foi construído com dimensões de 18,0 x 15,5 $\mathrm{cm}$ e peso de 6,02 $\mathrm{kg}$, exibido na Figura 3.19 a seguir. Estas dimensões e o formato retangular foram escolhidos visando percorrer a área da caixa com quatro linhas de compactação, porém com uma área 
relativamente pequena. Foi utilizada altura de queda de $18 \mathrm{~cm}$, gerando energia de 10,62 Joules a cada golpe.

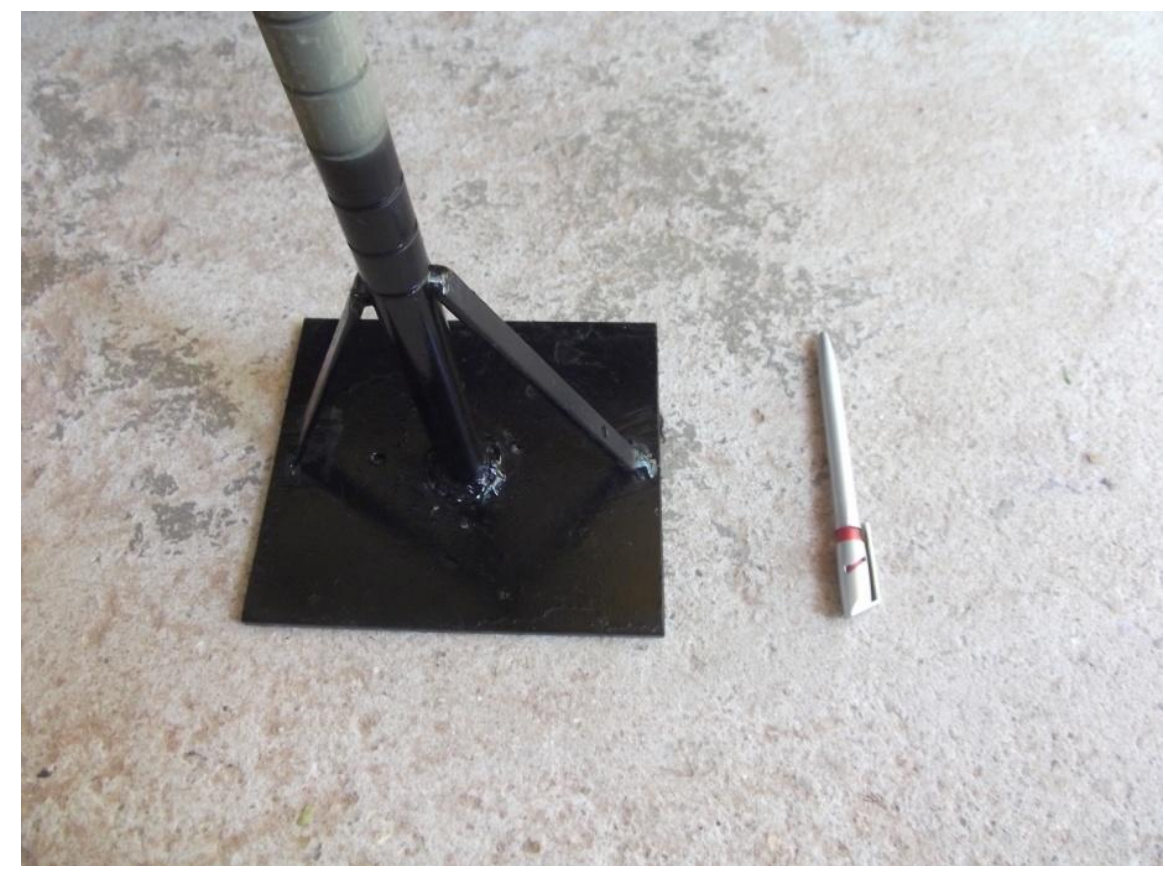

Figura 3.19 - Compactador manual utilizado na areia e brita.

Durante a calibração do sistema de compactação eram realizadas compactações com energias diferentes, buscando-se uma melhor eficiência na compactação de modo a se repetir a mesma compactação nas caixas de ensaios restantes. Um método de compactação semelhante já foi utilizado em pesquisas como Teixeira (2003), onde se utilizava um martelete mecânico e soquete manual para compactação dos solos.

A compacidade obtida era controlada através de recipientes de acrílico com volumes conhecidos, que eram posicionados no fundo da caixa de ensaios de modo a abranger de maneira representativa a área da caixa (Figura 3.20 a seguir). Com os recipientes na caixa a compactação era realizada e posteriormente eram medidos os graus de compactação nos recipientes. 
Além da utilização dos recipientes era conhecida a massa de solo lançada em cada camada, utilizando-se uma balança com capacidade de $1000 \mathrm{~kg}$ e resolução de $0,2 \mathrm{~kg}$. A altura da camada era medida (Figura 3.20 a seguir) e conhecendo-se a massa de solo utilizada era calculada a compacidade alcançada.

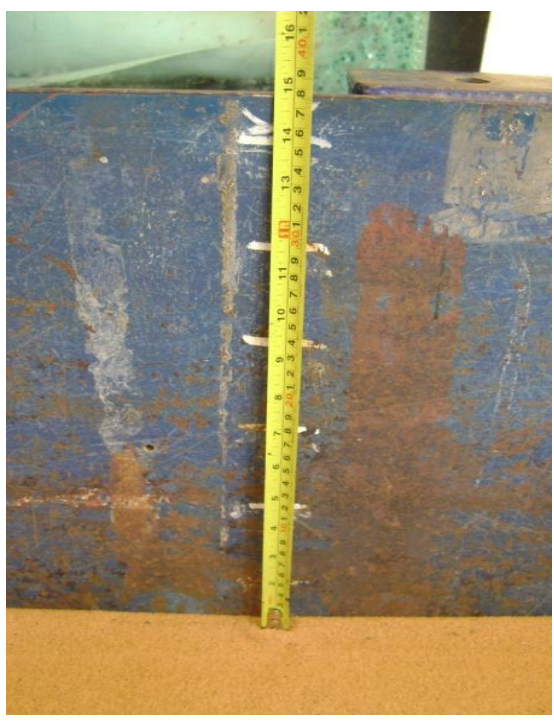

(a)

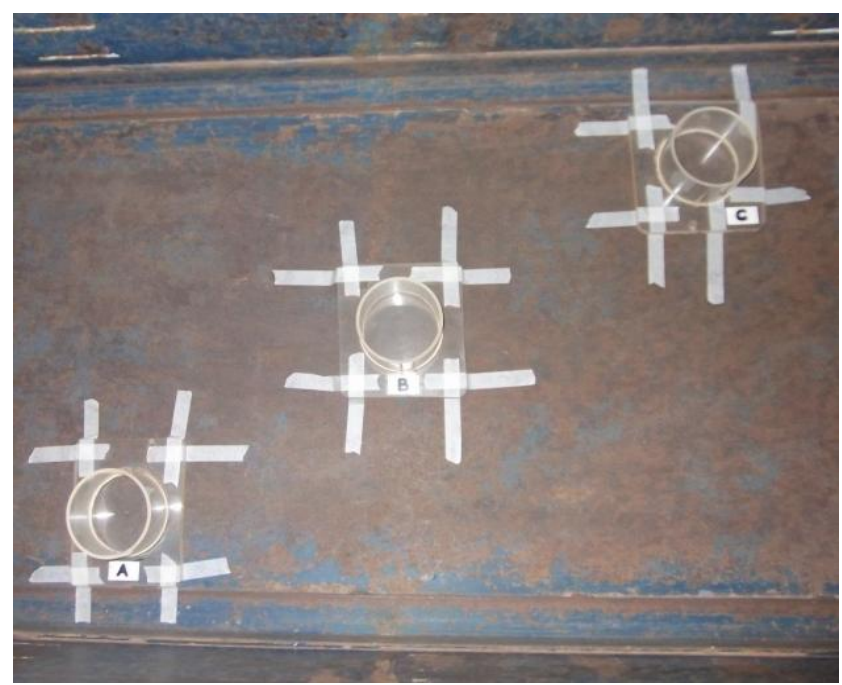

(b)

Figura 3.20 - Aferição de compacidade da areia, do silte e da brita.

No decorrer dos ensaios a compacidade era controlada através da massa de solo utilizada em cada camada, que era calculada almejando-se alturas de camadas determinadas de 50 a $80 \mathrm{~mm}$, medida em seis posições diferentes após a compactação de cada camada, buscando-se compacidade relativa final de $96 \%$ em cada camada.

A montagem dos ensaios com areia se dava com a montagem de duas camadas de solo e sua devida instrumentação, seguida do posicionamento da geogrelha já instrumentada, e posterior compactação de mais três camadas de solo sobre a geogrelha. 


\subsubsection{Brita}

Foi utilizada na pesquisa uma brita graduada simples, adquirida na pedreira do Grupo Bandeirantes, situada no município de São Carlos, Estado de São Paulo.

Este material grosseiro utilizado na pesquisa foi selecionado devido à sua utilização comum como parte de reforço de camada de base. No caso do uso de reforços como as geogrelhas, o reforço normalmente é aplicado sobre a camada de solo com baixa capacidade de suporte e acima do reforço é disposta a brita graduada, confinando o reforço entre as camadas de solo e brita. A camada de brita apresenta função de dissipar as tensões provenientes da capa asfáltica, assistida pelo reforço entre a camada de brita e a camada de solo abaixo, onde o reforço age diminuindo as tensões laterais impostas pela compressão da camada acima.

O comportamento das bases de brita graduada depende da interação das partículas componentes que incluem grãos de maiores dimensões até os grãos mais finos (DNER-1996). Em Carmo (2011) um solo grosseiro semelhante foi associado a uma geogrelha, reforçando um solo argiloso com baixa capacidade de suporte, para o tratamento da base e posterior construção de pavimento.

A brita graduada visa ainda representar a utilização de solo de granulometria mais grosseira, representando assim o comportamento do reforço sobre estas condições de solicitações do meio confinante. A brita graduada é exibida na Figura 3.21 a seguir. 


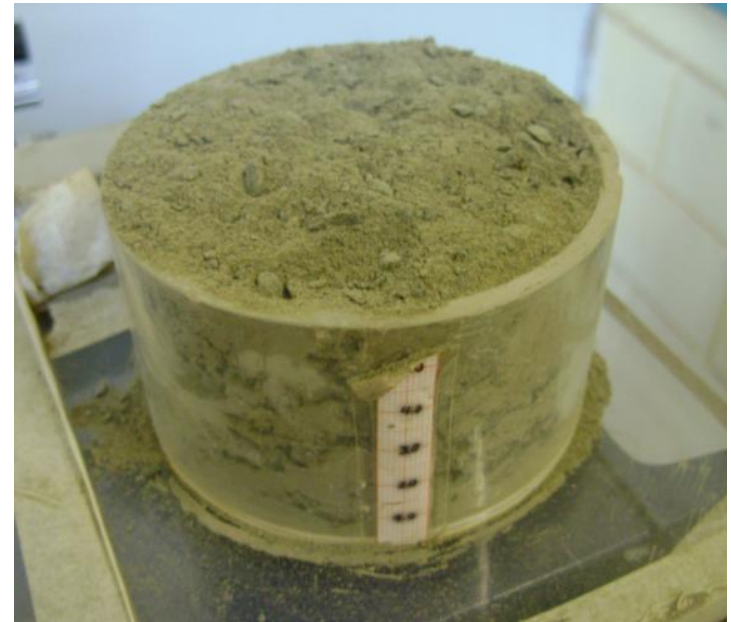

(a)

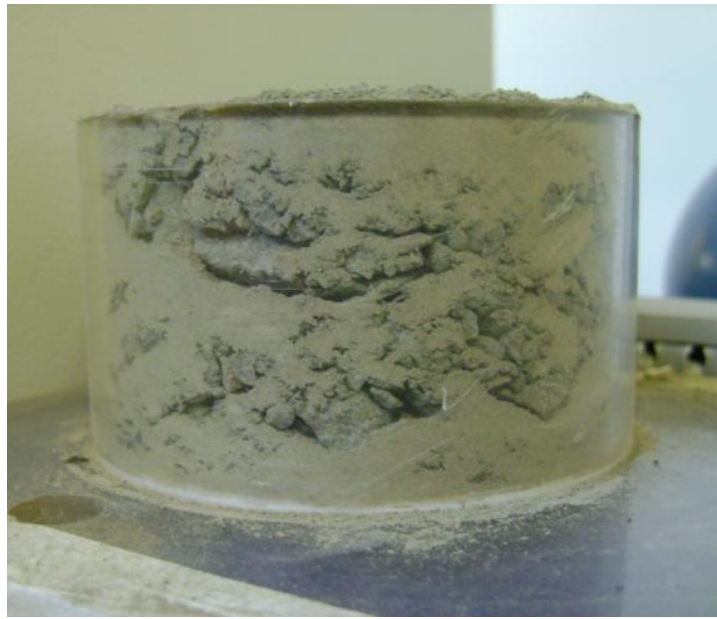

(b)

Figura 3.21 - Brita graduada simples utilizada na pesquisa.

A fim de obter uma faixa granulométrica específica (faixa C - DER) foram utilizados três materiais com granulometrias diferentes disponíveis na pedreira, sendo pedra 1", pedrisco e pó de pedra, que foram misturados com as devidas porcentagens calculadas através do método gráfico Rothfuchs. A curva granulométrica do material gerado após a mistura está representada a seguir (Figura 3.22) e se enquadra na faixa característica da gradação C das normas DER ET-DE-P00/008 (2005).

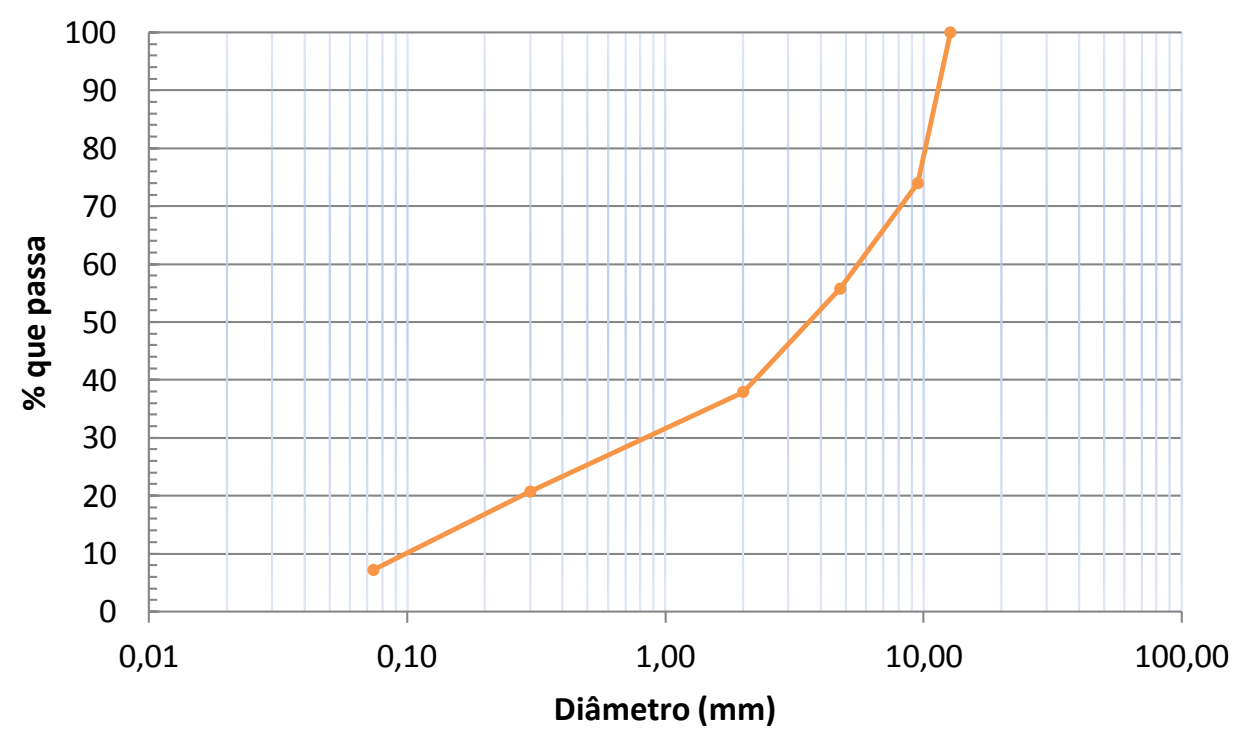

Figura 3.22 - Curva granulométrica da brita utilizada. 
Após a composição da brita a ser utilizada, foram realizados ensaios de caracterização, onde foram obtidos $\gamma_{s}=29,93\left(\mathrm{kN} / \mathrm{m}^{3}\right) \gamma_{d, \text { máx }}=21,58\left(\mathrm{kN} / \mathrm{m}^{3}\right)$ e $\gamma_{d, \min }=18,07\left(\mathrm{kN} / \mathrm{m}^{3}\right)$ de acordo com as normas ABNT 6508, ABNT MB-3324 e ABNT MB-3328, respectivamente.

\subsubsection{Compactação da brita}

Para os ensaios com brita graduada, optou-se por utilizar este material seco, assim como a areia. Sua preparação se iniciou com a exposição em local arejado até atingir teor de umidade baixo e constante. A brita era seca ao tempo até a umidade inferior a $1 \%$ e então era armazenada em bolsões de poliéster, que permaneciam em local seco e arejado para não haver alteração representativa de umidade.

Antes de iniciar a montagem dos ensaios, para este solo também foi feita uma calibração do método a ser utilizado na compactação, e devido às dimensões da caixa optouse por utilizar para a Brita o mesmo compactador manual tipo "soquete" utilizado na areia, mostrado anteriormente (Figura 3.19). Foi utilizada a mesma altura de queda $(0,18 \mathrm{~m})$, gerando a mesma energia utilizada na areia (10,62 Joules).

Assim como na areia, na brita a calibração do sistema de compactação era realizada utilizando energias diferentes, buscando-se uma melhor eficiência na compactação de modo a se repetir a mesma compactação nas caixas de ensaios restantes, e ainda eram utilizados os recipientes de acrílico (Figura 3.20 anterior) posicionados no fundo da caixa para aferição do grau de compactação obtido nos recipientes.

Além da utilização dos recipientes era conhecida a massa de solo lançada em cada camada, utilizando-se a mesma balança utilizada na areia. A altura da camada era medida, semelhante ao controle realizado na areia (Figura 3.20 anterior) e conhecendo-se a massa de solo utilizada era calculada a densidade e compacidade alcançada. A compacidade era 
controlada através da massa de solo utilizada em cada camada, que era calculada almejandose alturas de camadas determinadas de 50 a $80 \mathrm{~mm}$, medida em seis posições diferentes após a compactação de cada camada, e buscando-se compacidade relativa final de $94 \%$ em cada camada.

A montagem dos ensaios com brita se dava com a montagem de três camadas de solo e sua devida instrumentação, seguida do posicionamento da geogrelha já instrumentada, e posterior compactação de mais três camadas de solo sobre a geogrelha.

\subsubsection{Silte}

Foi utilizado na pesquisa um solo fino de alteração (Figura 3.23), um silte argiloarenoso roxo, coletado em um afloramento presente em um corte rodoviário, às margens da rodovia SP-215, km 152,5 sentido Ribeirão Bonito, nas coordenadas 2203’59”S 4754’36”O.

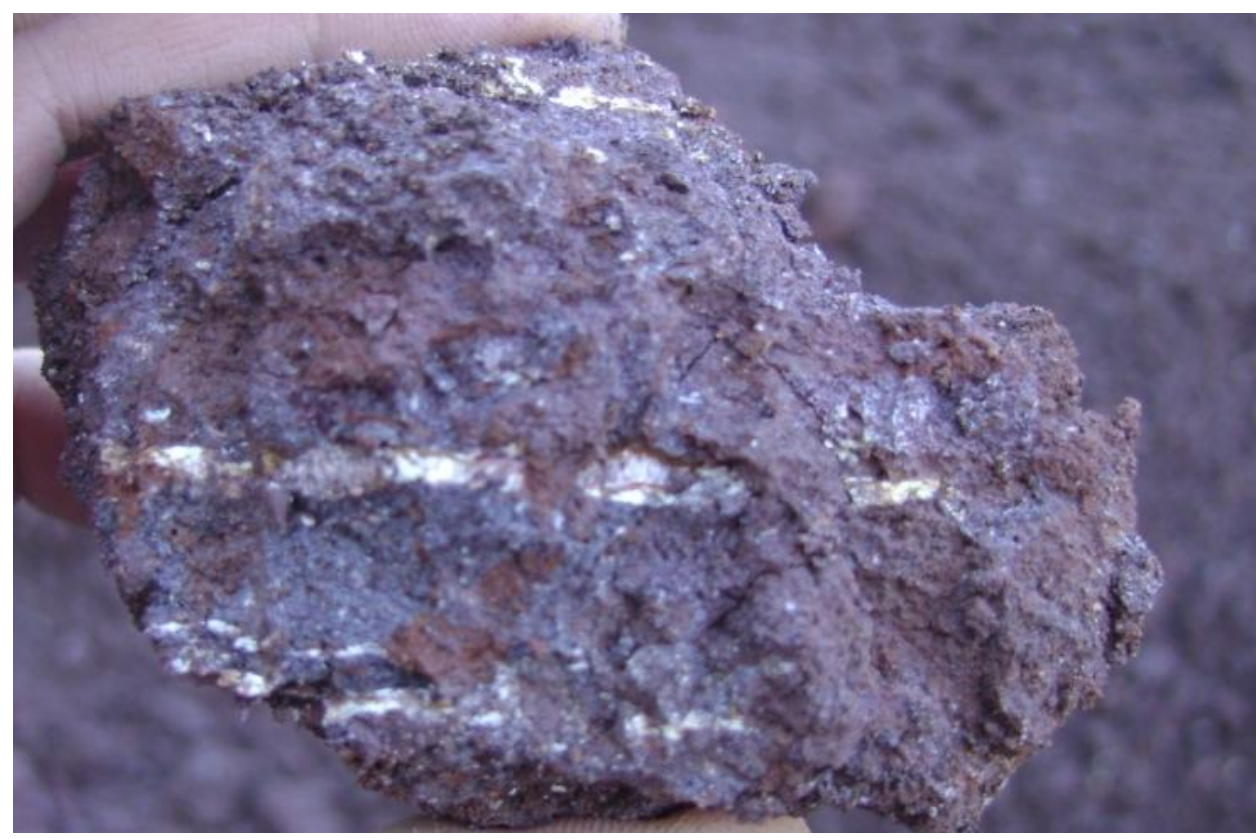

Figura 3.23 - Silte argiloso utilizado na pesquisa. 
O silte utilizado visa representar a utilização de solo de granulometria mais fina, representando assim o comportamento do reforço sob estas condições de meio confinante. Este silte foi selecionado devido às suas características conhecidas de baixa capacidade de carga, apresentando $\mathrm{CBR}$ em torno de $5 \%$. O mesmo material foi utilizado em outras pesquisas como Maparagem (2011) e Kakuda (2011) devido a estas características.

As características do silte argiloso obtidas por meio de ensaios normatizados são expostas na Tabela 3.5 a seguir.

Tabela 3.5 - Características do Silte.

\begin{tabular}{|c|c|c|c|}
\hline Massa específica & $V_{s}\left(k N / m^{3}\right)$ & 30,06 & ABNT 6508 \\
\hline \multirow{2}{*}{$\begin{array}{l}\text { Compactação } \\
\text { Proctor normal }\end{array}$} & $V_{d, \text { máx }}\left(k N / m^{3}\right)$ & 15,10 & \multirow{2}{*}{$\begin{array}{c}\text { ABNT NBR } \\
7182\end{array}$} \\
\hline & $W_{o t}(\%)$ & 30 & \\
\hline \multirow{5}{*}{$\begin{array}{c}\text { Granulometria } \\
\text { conjunta }\end{array}$} & Argila (\%) & 35 & \multirow{5}{*}{$\begin{array}{c}\text { ABNT NBR } \\
6502\end{array}$} \\
\hline & Silte (\%) & 42 & \\
\hline & Areia fina (\%) & 11 & \\
\hline & Areia média (\%) & 10 & \\
\hline & Areia grossa (\%) & 2 & \\
\hline \multirow{4}{*}{$\begin{array}{l}\text { Limites de } \\
\text { consistência }\end{array}$} & LL (\%) & 67 & MB 30 \\
\hline & LP (\%) & 38 & MB 31 \\
\hline & IP & 29 & \\
\hline & LC (\%) & 26,6 & ABNT MB 55 \\
\hline \multicolumn{2}{|c|}{ Classificação } & $\mathrm{MH}$ & SUCS \\
\hline
\end{tabular}

\subsubsection{Compactação do Silte}

Para os ensaios com silte argiloso, optou-se por utilizar este material na umidade ótima, a fim de proporcionar uma melhor compactação e sem excesso de água intersticial, que poderia gerar pressões neutras durante o ensaio. 
A preparação do material se iniciou com sua homogeneização, buscando teor de umidade homogêneo e constante. $\mathrm{O}$ silte era então armazenado em bolsões de poliéster, que permaneciam em local seco e arejado para não haver alteração de umidade do material.

Imediatamente antes do início dos ensaios era aferida a umidade do material e a mesma era corrigida no mesmo dia da montagem da caixa de ensaios, proporcionando a menor perda de umidade possível.

Antes de iniciar a montagem dos ensaios foi feita uma calibração do método a ser utilizado na compactação, e optou-se por utilizar para o Silte um compactador manual tipo "soquete". Este compactador era cilíndrico com 16,0 $\mathrm{cm}$ de diâmetro e peso de 9,58 $\mathrm{kg}$, mostrado na Figura 3.24 a seguir. Foi utilizada altura de queda de $22 \mathrm{~cm}$, gerando energia de 20,65 Joules a cada golpe.

$\mathrm{Na}$ calibração do sistema de compactação foram realizadas compactações com energias diferentes, visando uma maior eficiência na compactação, a fim de se repetir a mesma compactação nos ensaios restantes, semelhante ao realizado na areia e brita.

Assim como nos materiais anteriores (areia e brita), para controle da compacidade obtida, foram utilizados recipientes de acrílico com volumes conhecidos posicionados no fundo da caixa de ensaios, além do controle da massa de solo lançada em cada camada, que era calculada buscando-se alturas de camadas de 50 a $80 \mathrm{~mm}$, medida em seis posições diferentes após a compactação de cada camada, buscando-se grau de compactação final de 96 $\%$ por camada.

A montagem dos ensaios com silte se dava com a montagem de três camadas de solo e sua devida instrumentação, seguida do posicionamento da geogrelha já instrumentada, e posterior compactação de mais três camadas de solo sobre a geogrelha. 


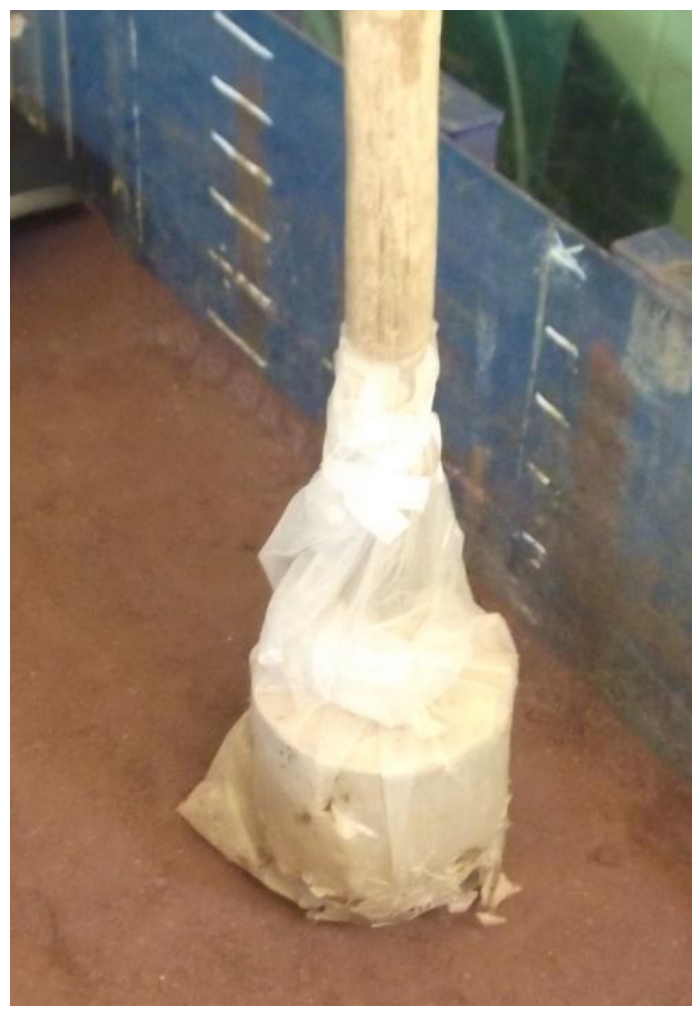

Figura 3.24 - Compactador manual utilizado no silte.

Após cada camada as alturas eram medidas e se conferia o grau de compactação, determinando ainda a altura das próximas camadas.

\subsection{Programa de ensaios}

Inicialmente foram realizados ensaios de arrancamento estático nos solos denominados areia (A), brita (B) e silte (C), reforçados com geogrelha sob as condições de tensão confinante, dimensões do corpo de prova, grau de compacidade e umidade discriminados na Tabela 3.6 a seguir. De posse das informações dos ensaios de arrancamento estático, passou-se a definir as condições dos ensaios cíclicos de arrancamento que apresentavam as características mostradas também na Tabela 3.6 a seguir. 
Tabela 3.6 - Características dos ensaios de arrancamento.

\begin{tabular}{|c|c|c|c|c|c|c|c|}
\hline & \multirow[b]{2}{*}{$\begin{array}{c}\text { Solo } \\
\text { confinante }\end{array}$} & \multirow[b]{2}{*}{ Denominação } & \multicolumn{2}{|c|}{ Dimensões do CP } & \multirow{2}{*}{$\begin{array}{c}\text { Tensão } \\
\text { confinante } \\
(k P a)\end{array}$} & \multirow[b]{2}{*}{$\begin{array}{c}\text { Umidade } \\
(w)\end{array}$} & \multirow[b]{2}{*}{$\begin{array}{c}V_{\text {ensaio }} \\
\left(\mathrm{kN} / \mathrm{m}^{3}\right)\end{array}$} \\
\hline & & & $\begin{array}{l}\text { Largura } \\
(\mathrm{mm})\end{array}$ & $\begin{array}{c}\text { Comprimento } \\
(\mathrm{mm})\end{array}$ & & & \\
\hline Arrancamento 01 & \multirow{7}{*}{ Areia $(A)$} & AA1 & 376 & 510 & $75^{*}$ & \multirow{7}{*}{$<1 \%$} & \multirow{7}{*}{15,18} \\
\hline Arrancamento 02 & & AA2 & 376 & 510 & 75 & & \\
\hline Arrancamento 03 & & AA3 & 376 & 510 & 55 & & \\
\hline Arrancamento 04 & & AA4 & 376 & 510 & 40 & & \\
\hline Arrancamento 05 & & AA5 & 376 & 510 & 25 & & \\
\hline Cíclico 01 & & CA1 & 376 & 510 & $25 / 40 / 55$ & & \\
\hline Cíclico 02 & & CA2 & 376 & 510 & $25 / 40 / 55$ & & \\
\hline Arrancamento 06 & \multirow{5}{*}{ BGS (B) } & $A B 1$ & 376 & 510 & 25 & \multirow{5}{*}{$<1 \%$} & \multirow{5}{*}{20,29} \\
\hline Arrancamento 07 & & $A B 2$ & 376 & 510 & 40 & & \\
\hline Arrancamento 08 & & AB3 & 376 & 510 & 55 & & \\
\hline Cíclico 04 & & $\mathrm{CB1}$ & 376 & 510 & $25 / 40 / 55$ & & \\
\hline Cíclico 05 & & $\mathrm{CB} 2$ & 376 & 510 & $25 / 40 / 55$ & & \\
\hline Arrancamento 09 & \multirow{4}{*}{ Silte (C) } & $\mathrm{AC1}$ & 376 & 510 & 25 & \multirow{4}{*}{$28 \%$} & \multirow{4}{*}{14,50} \\
\hline Arrancamento 10 & & $\mathrm{AC2}$ & 376 & 510 & 40 & & \\
\hline Arrancamento 11 & & $\mathrm{AC} 3$ & 376 & 510 & 55 & & \\
\hline Cíclico 06 & & CC1 & 376 & 510 & $25 / 40 / 55$ & & \\
\hline
\end{tabular}

*Ocorreu variação da tensão confinante durante o ensaio, devido a problemas externos. Este ensaio foi desconsiderado.

Na realização dos ensaios optou-se por variar poucos parâmetros a fim de detalhar a influência dos mesmos e compreender o comportamento obtido.

A tensão confinante utilizada nos ensaios foi da mesma ordem de grandeza das utilizadas pelas normas DNER ME 131 (1994) e DNIT ME 134 (2010) que tratam de determinação de resiliência de solos, onde a DNER cita a utilização de tensões confinantes de 52,5 a $140 \mathrm{kPa}$ e a DNIT relata ensaios com tensões confinantes de 20,7 a 137,9 $\mathrm{kPa}$, buscando representar as tensões atuantes em camadas de solo de base e sub-base de pavimentos.

O reforço utilizado nos ensaios apresenta o comprimento padronizado em $500 \mathrm{~mm}$ e largura de $376 \mathrm{~mm}$, permitindo a distância mínima de $150 \mathrm{~mm}$ do corpo de prova em relação 
às paredes da caixa de ensaios previsto na norma ASTM 7499 (2009), visando à eliminação de efeitos de contorno. Estas dimensões do reforço são referentes à área ancorada logo à frente da manga presente na caixa de ensaios, que é utilizada para diminuir a influência do atrito lateral das paredes (KAKUDA, 2005).

\subsubsection{Instrumentação da amostra}

A instrumentação da amostra fornece parâmetros importantes de comportamento ao longo do ensaio. Buscando-se obter o comportamento do corpo de prova as extremidades dos fios dos sensores de deslocamento foram fixadas no reforço como mostrado na Figura 3.25 a seguir, através do entrelaçamento e colagem do fio aos filamentos da geogrelha, e distribuídos ao longo do comprimento e da largura do corpo de prova, na diagonal, como ilustrado na Figura 3.26 a seguir. Tal modelo de instrumentação foi utilizado nos ensaios A1 e A2.

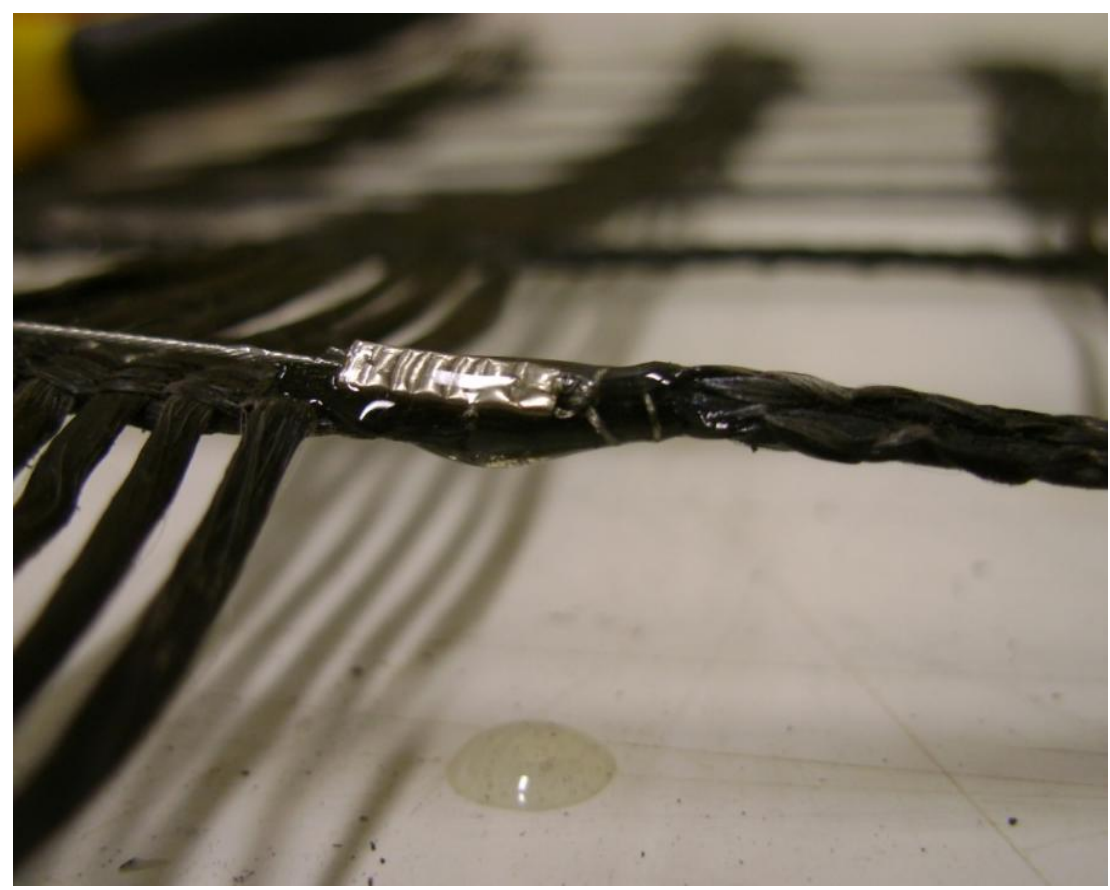

Figura 3.25 - Detalhe da fixação dos fios dos transdutores de deslocamentos. 


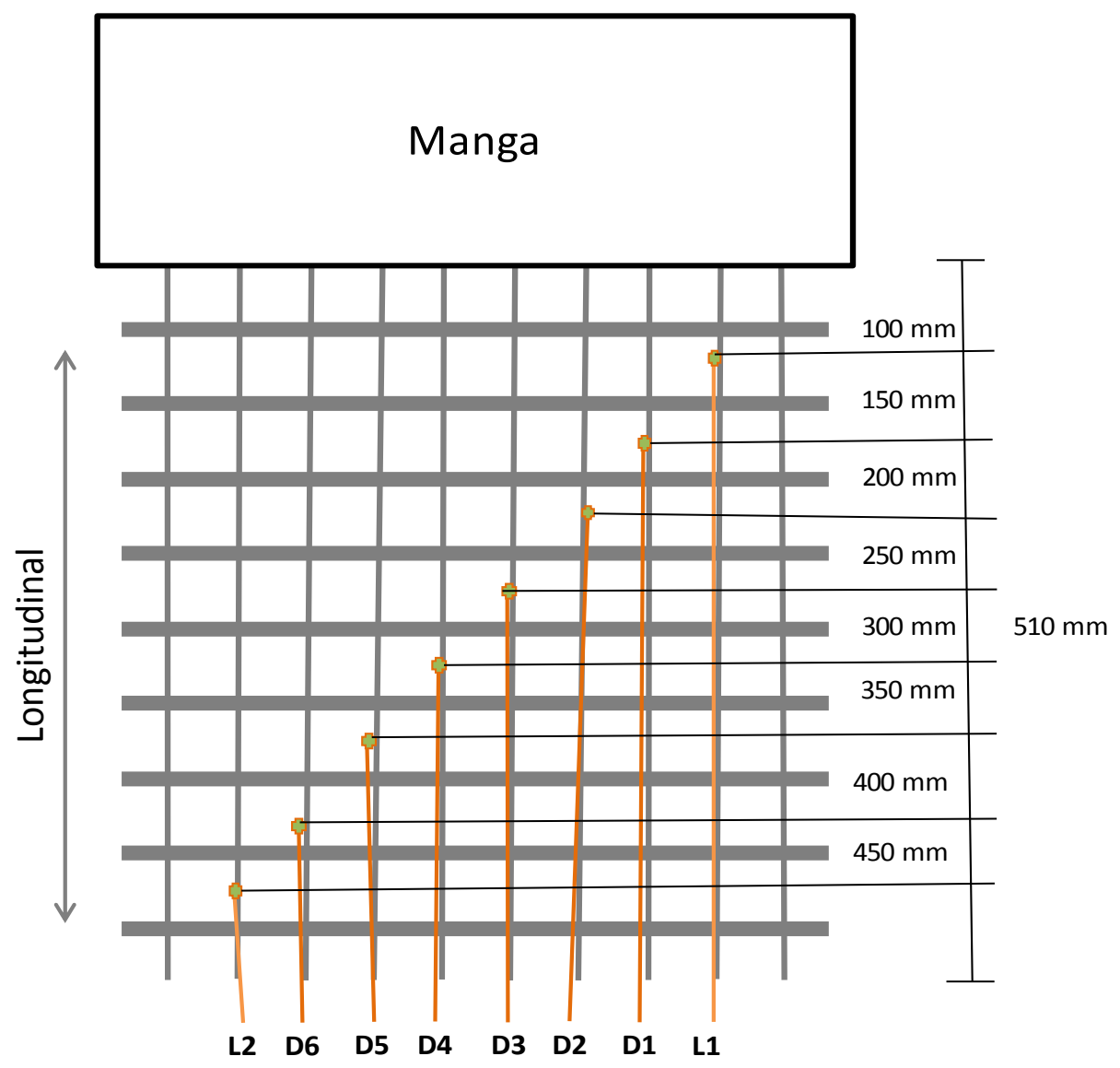

Figura 3.26 - Layout A dos pontos de medição de deslocamentos da geogrelha.

Para o restante dos ensaios optou-se por utilizar instrumentação semelhante, porém, com dois sensores fixados em um mesmo elemento, em dois elementos centrais, buscando-se verificar se o comportamento individual de um elemento era semelhante ao dos elementos de seu entorno. Durante o restante dos ensaios, as amostras eram instrumentadas de maneira semelhante, ainda buscando verificar o deslocamento ao longo do corpo de prova, logo, o nível de solicitação da amostra a cada distância da aplicação da carga. Para o restante dos ensaios os sensores eram posicionados na amostra como ilustrado na Figura 3.27 a seguir. 


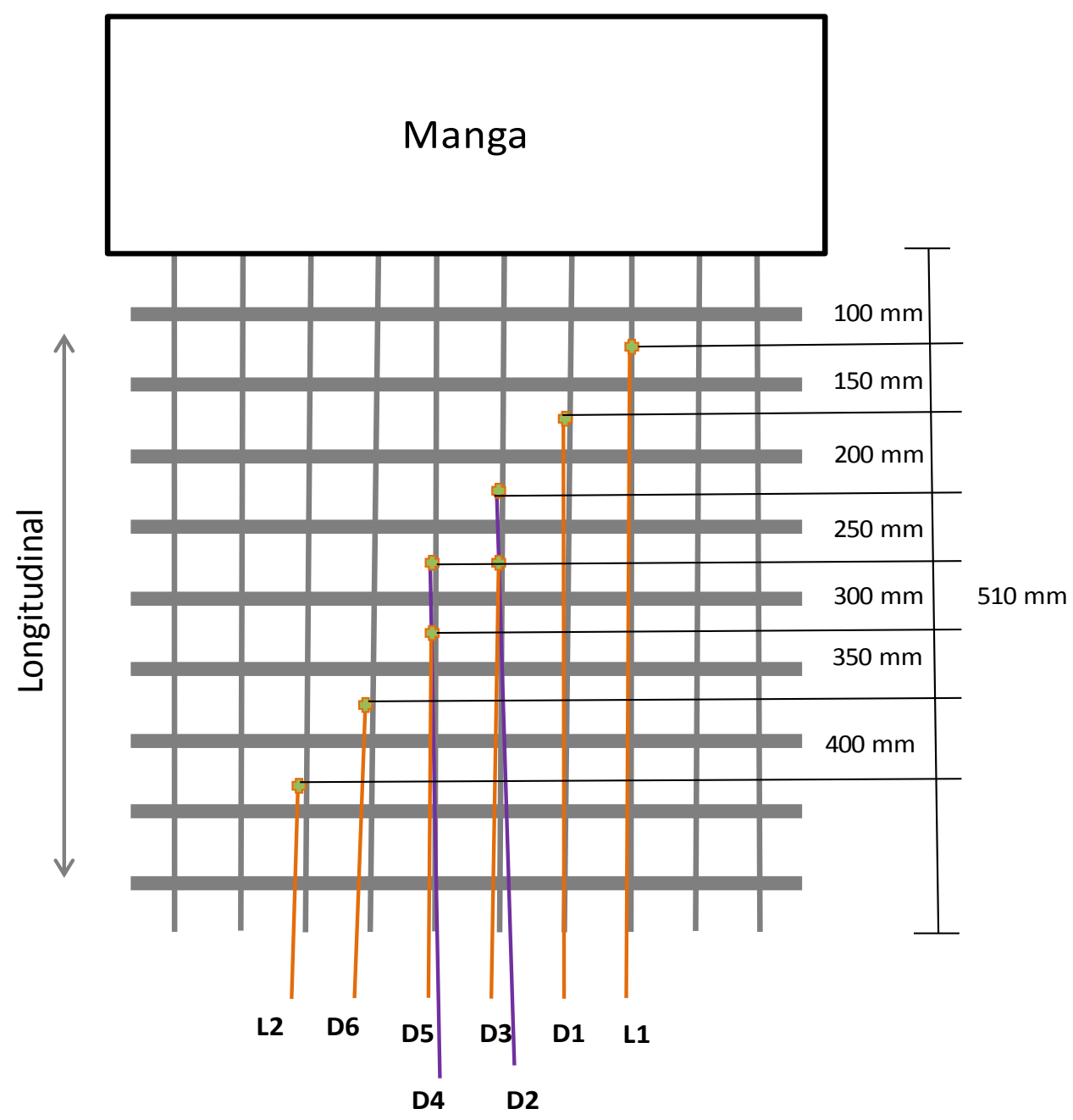

Figura 3.27 - Layout B dos pontos de medição de deslocamentos da geogrelha.

Inicialmente eram realizados ensaios de arrancamento nos solos mantendo-se o mesmo material de reforço (com outro corpo de prova), a mesma geometria, o mesmo grau de compactação e parâmetros como umidade, variando-se apenas a sobrecarga aplicada pela bolsa de ar. Com estes ensaios de arrancamento eram obtidas "curvas" de tendência ou envoltórias que serviriam de parâmetro para a realização das ciclagens.

Adicionalmente foram verificados os níveis de tensão ao longo da amostra horizontalmente e verticalmente, buscando-se avaliar o comportamento de distribuição das tensões no entorno do reforço. Para isto foram utilizadas células de tensão total, denominadas $\mathrm{H} 1, \mathrm{H} 2$ e $\mathrm{H} 3$ as utilizadas na horizontal e V1, V2 e V3 as utilizadas na vertical. Os 
dispositivos eram posicionados na caixa de ensaios de acordo com o esquema da Figura 3.28 a seguir.

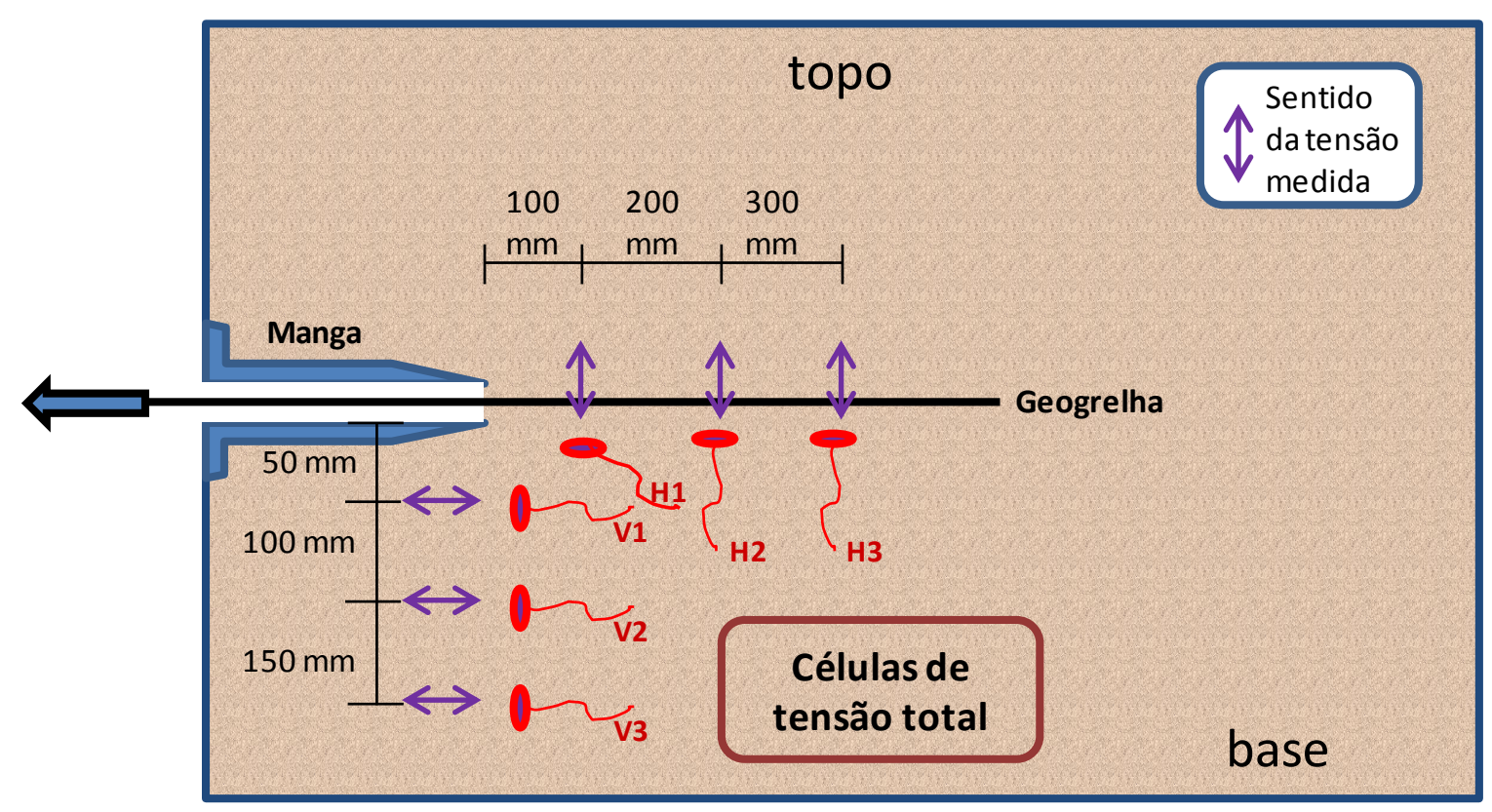

Figura 3.28 - Corte vertical da caixa de ensaios com a distribuição das células de tensão total. 


\section{Resultados e Discussões}

Neste capítulo são apresentados os resultados dos ensaios de arrancamento e cíclicos realizados nos três tipos de solos confinantes reforçados. São detalhados os comportamentos individuais de cada material, e ao final são feitos comparativos dos resultados.

\section{1 $\underline{\text { Areia }}$}

\subsubsection{Arrancamento Areia}

A areia é um tipo de solo onde, comumente, predominam condições drenadas de solicitação e tem seu comportamento mecânico governado pelo índice de vazios e pela tensão confinante. Este solo foi inicialmente utilizado nesta pesquisa para calibração dos equipamentos, tanto nos ensaios de arrancamento estático quanto nos cíclicos. Nessa perspectiva foram montados ensaios com a areia seca, mantendo-se constantes as densidades, variando-se apenas as tensões normais de confinamento com o intuito de não haver interferência de outros fatores.

Os ensaios de arrancamento deste grupo de ensaios geraram uma extensa gama de resultados, entre eles estão as curvas força versus deslocamento expostas a seguir (Figura 4.1), referentes às tensões confinantes de 25, 40, 55 e $75 \mathrm{kPa}$. 


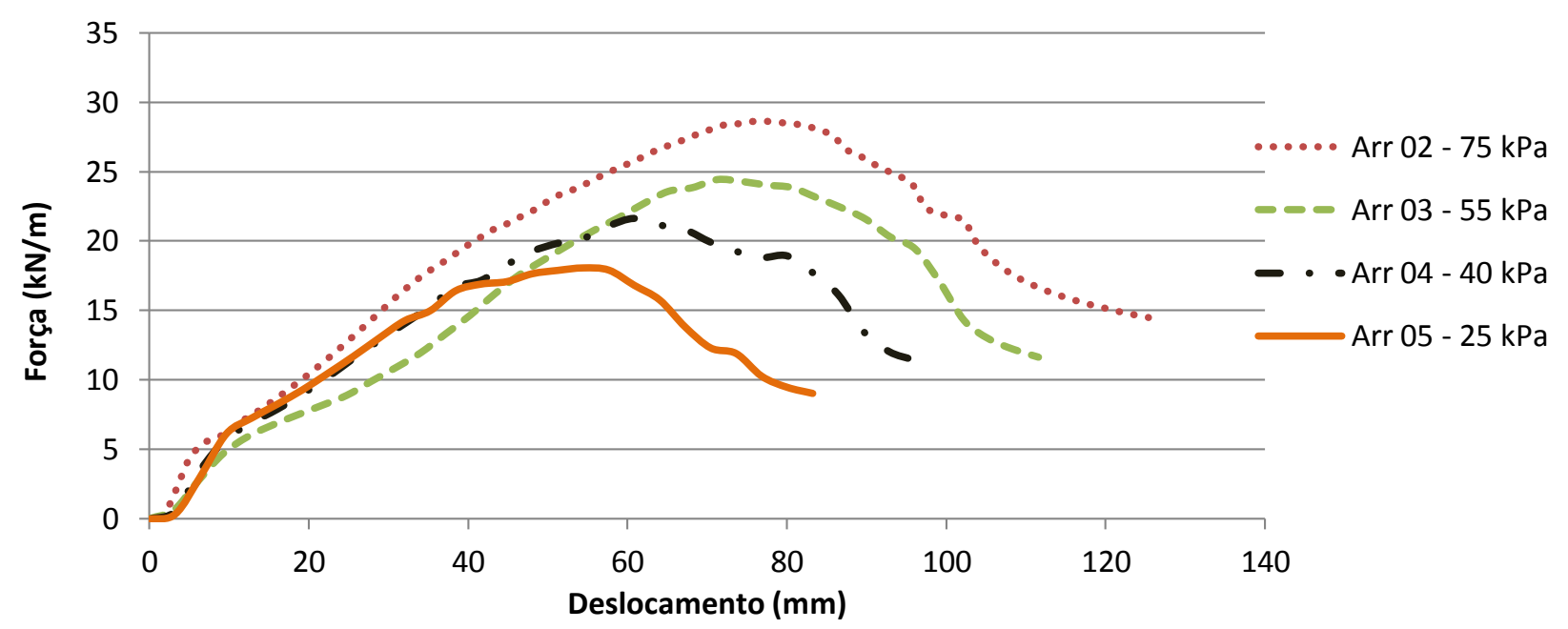

Figura 4.1 - Curvas de força de arrancamento versus deslocamento da garra em areia.

Como cada um dos ensaios de arrancamento foi instrumentado segundo o sistema B descrito anteriormente, quanto a deslocamentos no reforço e quanto às tensões horizontais e verticais no seu entorno, foi possível obter as curvas de força versus deslocamento em diversas posições da geogrelha, como se ilustra na Figura 4.2 a seguir.

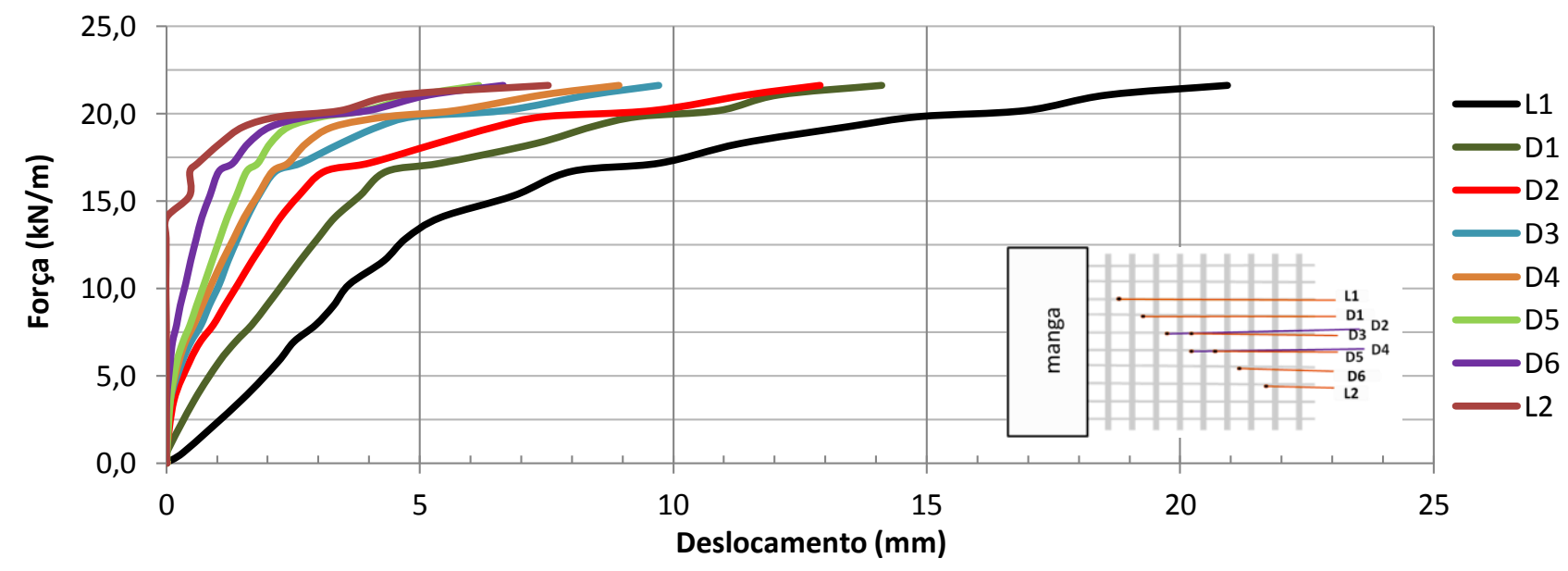

Figura 4.2 - Deslocamento dos sensores ao longo da amostra durante ensaio com tensão, $\sigma$, de $40 \mathrm{kPa}$ em areia (Ensaio AA4).

As curvas de força versus deslocamento apresentaram comportamento semelhante em todos os ensaios de arrancamento na areia, podendo-se considerar as curvas da Figura 4.2 
como típicas. Nela aparece também um esquema com as posições dos diversos transdutores de deslocamento utilizados.

O gráfico mostra que inicialmente ocorrem deslocamentos nos elementos mais próximos à aplicação da força cisalhante (frente), e com o aumento da força as partes mais ancoradas (traseira) da amostra são solicitadas e apresentam deslocamento gradativo.

Foi possível ainda, a partir das medidas locais ao longo do corpo de prova, determinar os deslocamentos em função da distância da aplicação da força de arrancamento, distância esta medida a partir da manga, para cada nível de força aplicada. Estes resultados encontramse na Figura 4.3 a seguir.

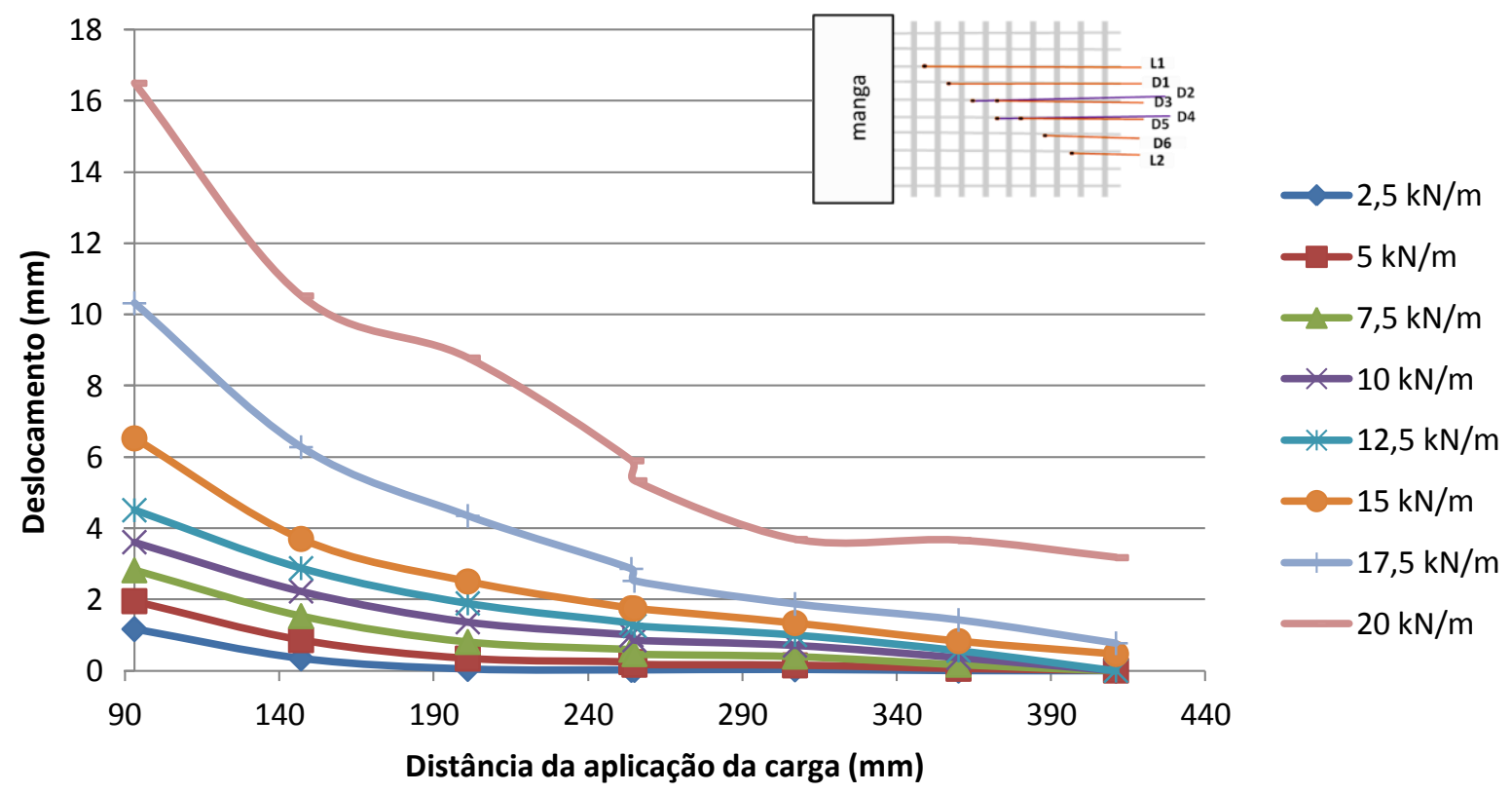

Figura 4.3 - Solicitações ao longo do corpo de prova em ensaio de arrancamento com tensão, $\sigma$, de $40 \mathrm{kPa}$ em areia (Ensaio AA4).

Considerando-se que quando a amostra é solicitada ocorre deslocamento gradual, no gráfico anterior nota-se que com força de $2,5 \mathrm{kN} / \mathrm{m}$ ocorre solicitação de cerca de $180 \mathrm{~mm}$ de comprimento de amostra, com força de $5 \mathrm{kN} / \mathrm{m}$ a solicitação aumenta para cerca de $270 \mathrm{~mm}$. 
Com força de $10 \mathrm{kN} / \mathrm{m}$ mais de $380 \mathrm{~mm}$ da amostra é solicitada, e, a partir da força de 15 $k N / m$, o reforço é integralmente solicitado, levando ao seu arrancamento completo da massa de solo.

O acompanhamento das tensões normais durante os ensaios de arrancamento permitiu elaborar o gráfico da Figura 4.4 a seguir, considerando a distribuição das células de tensão total feita de acordo com a Figura 3.28 anterior. Em todos os ensaios de arrancamento em areia foram obtidos comportamentos semelhantes aos ilustrados na Figura 4.4 a seguir.

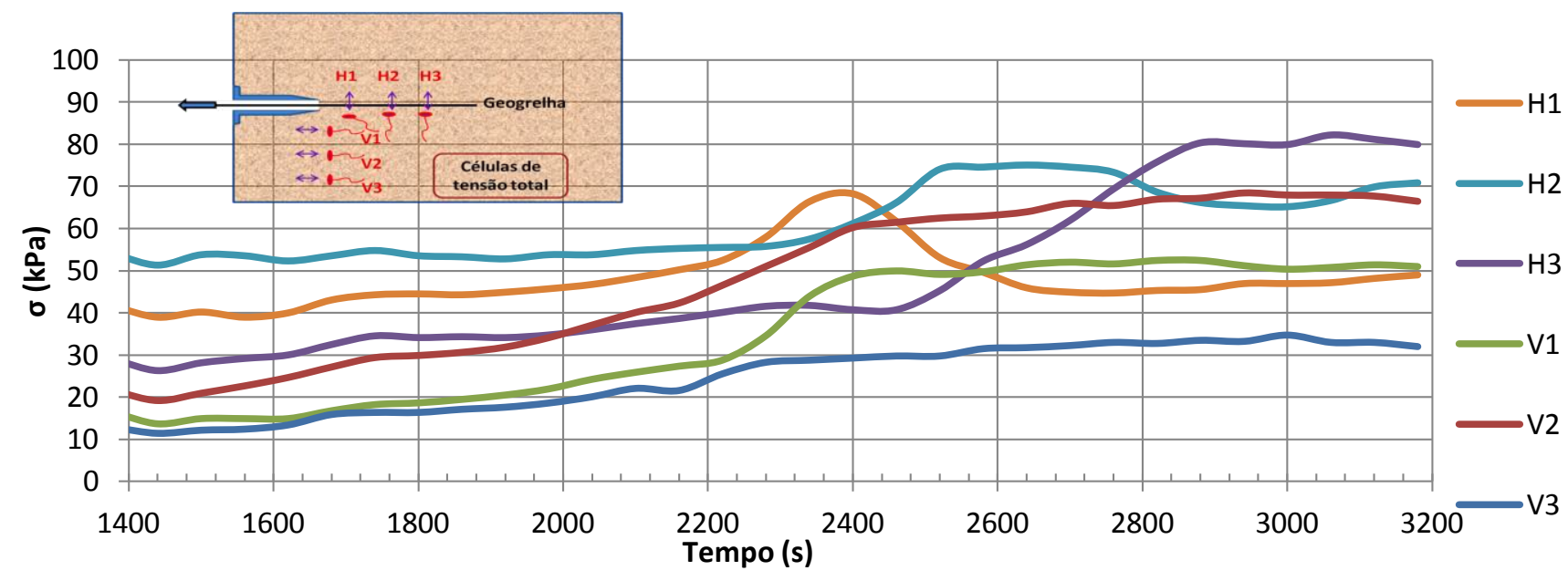

Figura 4.4-Arrancamento com tensão, $\sigma$, de 55 kPa em areia (Ensaio AA3).

O gráfico mostra que ocorrem tensões diferentes em regiões diferentes da caixa de ensaios. Em regiões mais distantes da manga são registradas tensões maiores do que em suas proximidades, comprovando a influência da mesma nas tensões que chegam efetivamente ao solo.

Pôde-se perceber que a variação das tensões ocorre conforme o ensaio é realizado. $\mathrm{O}$ sensor posicionado de forma horizontal (leituras de tensão vertical) mais próximo à aplicação de carga (H1) apresenta elevação da tensão conforme o material é tracionado, seguido pelo aumento no sensor posicionado ao meio do reforço $(\mathrm{H} 2)$ e consecutivamente pelo aumento da 
tensão ao final da ancoragem (H3). Em todos os sensores horizontais, logo em seguida ao aumento de tensão ocorre sua diminuição, com retorno ao valor inicial. Tal fato provavelmente ocorre por causa da expansão do solo no início da mobilização do reforço. Consequentemente aumenta a tensão ao redor do reforço, que logo sofre ligeiro desconfinamento com redistribuição das tensões ao longo do comprimento ancorado da amostra, e diminuição das tensões novamente.

Os sensores posicionados ao longo da vertical (leituras de tensão horizontal) mostram a variação das tensões em dada distância vertical, conforme é realizado o arrancamento do reforço. Verifica-se que os sensores com até $100 \mathrm{~mm}$ de distância da amostra apresentam alteração mais pronunciada de tensão, enquanto o sensor posicionado a $150 \mathrm{~mm}$ registra alterações relativamente menores de tensão.

A fim de confirmar o comportamento obtido as células de tensão total eram trocadas aleatoriamente, porém, mantidas nas mesmas posições em relação à amostra. Foi observado comportamento semelhante para todos os ensaios de arrancamento.

\subsubsection{Ciclagem Areia}

A partir dos ensaios de arrancamento realizados com diversas tensões confinantes obteve-se a envoltória de arrancamento representada na Figura 4.5 a seguir e que tem por equação (4.1):

$$
F(k N / m)=13,4+\sigma(k P a) * \operatorname{tg} 11,5^{\circ}
$$

Com base na envoltória de arrancamento foram calculadas as envoltórias referentes a 20, 40 e $60 \%$ da força máxima de arrancamento, denominada $F_{\text {máx }}$, resultando em valores fixos de carga para cada tensão confinante. Foram utilizados os níveis de 20, 40 e $60 \%$ da 
força máxima de arrancamento, pois no decorrer dos ciclos a areia se desconfinava através do vão entre as mangas superiores e inferiores conforme o reforço era carregado e descarregado. Isto limitava o número de ciclagens total antes do corpo de prova ficar em solo desconfinado, impossibilitando a realização de mais níveis de carregamentos. Tal fato ocorreu devido à deformabilidade do material de reforço, que durante cada carregamento do ciclo se alongava em direção à garra e retornava à posição inicial de ancoragem, acumulando pequenos deslocamentos.

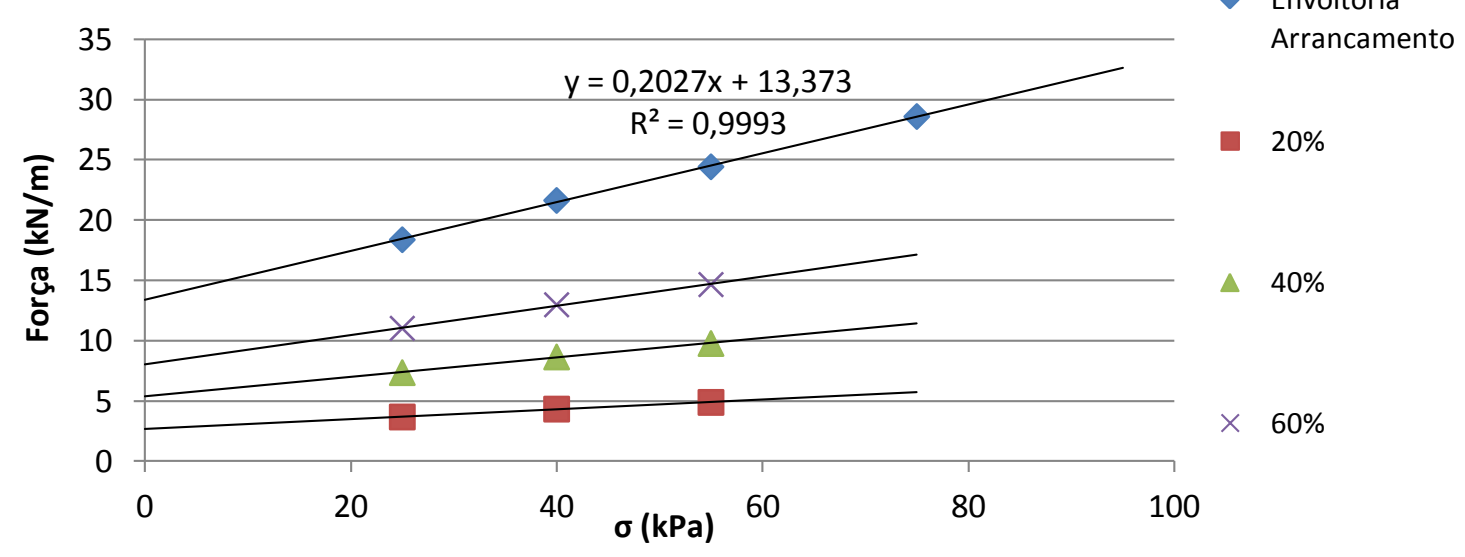

Figura 4.5 - Envoltória de resistência ao arrancamento em areia.

A realização das ciclagens se dava com a aplicação de 1000 ciclos referentes ao condicionamento do conjunto (ASTM 7499-2009, PERKINS 2004) visando à estabilização de parâmetros inerentes ao solo. O condicionamento foi realizado com uma carga cíclica e tensão confinante média em relação à programação de carregamentos aplicados, que para a areia foi de $40 \%$ da $F_{\text {máx }}$ e tensão confinante de $40 \mathrm{kPa}$.

Após a ciclagem de condicionamento os níveis de ciclagem eram iniciados pelo carregamento de menor intensidade $\left(20 \%\right.$ da $F_{\text {máx }}$ ) buscando-se manter a integridade do corpo do sistema solo-reforço. De acordo com as envoltórias citadas anteriormente o ensaio era iniciado com nível de $20 \%$ da $F_{\text {máx }}$ e tensão confinante, $\sigma$, de $25 \mathrm{kPa}$. Nos estágios 
seguintes, mantida constante a força de $20 \%$ da $F_{\text {máx }}$ as tensões confinantes eram aumentadas para 40 e $55 \mathrm{kPa}$, juntamente com aumento na força de ciclagem, representados na Figura 4.6 a seguir. Finalizada esta série de ensaios com nível de $20 \%$ da $F_{\text {máx }}$ o ensaio prosseguia repetindo-se o procedimento de aumento da confinante, porém, com nível de Força de Arrancamento de $40 \%$ da $F_{\text {máx }}$ e por fim o procedimento era repetido para Força de arrancamento de $60 \%$ da $F_{\text {máx }}$.

Ao final desta série de ensaios de arrancamento cíclico foi realizada uma série adicional de ensaios com características de carregamento e tensão confinante iguais às do nível de condicionamento. Esta nova série foi denominada recondicionamento. Nesta série foram aplicados 4000 ciclos a fim de verificar a estabilização dos deslocamentos gerados pelos diferentes níveis de carregamentos $\left(20,40\right.$ e $60 \%$ da $F_{\text {máx }}$ ) e tensões ( $\sigma$ de 25,40 e 55 $\mathrm{kPa}$ ) aplicados anteriormente.

São representados no gráfico a seguir os níveis de carregamentos aplicados e os deslocamentos registrados nos transdutores de deslocamentos D2 e D5 posicionados próximo à aplicação de força (à frente) e mais ancorados (atrás), respectivamente, buscando representar o comportamento em termos de deslocamentos em diferentes pontos do corpo de prova.

O gráfico a seguir (Figura 4.6) mostra ainda o deslocamento médio do reforço em cada nível de solicitação, tendo em vista que os sensores (D2 e D5) são posicionados em posições equidistantes da frente e da traseira do corpo de prova, respectivamente. 


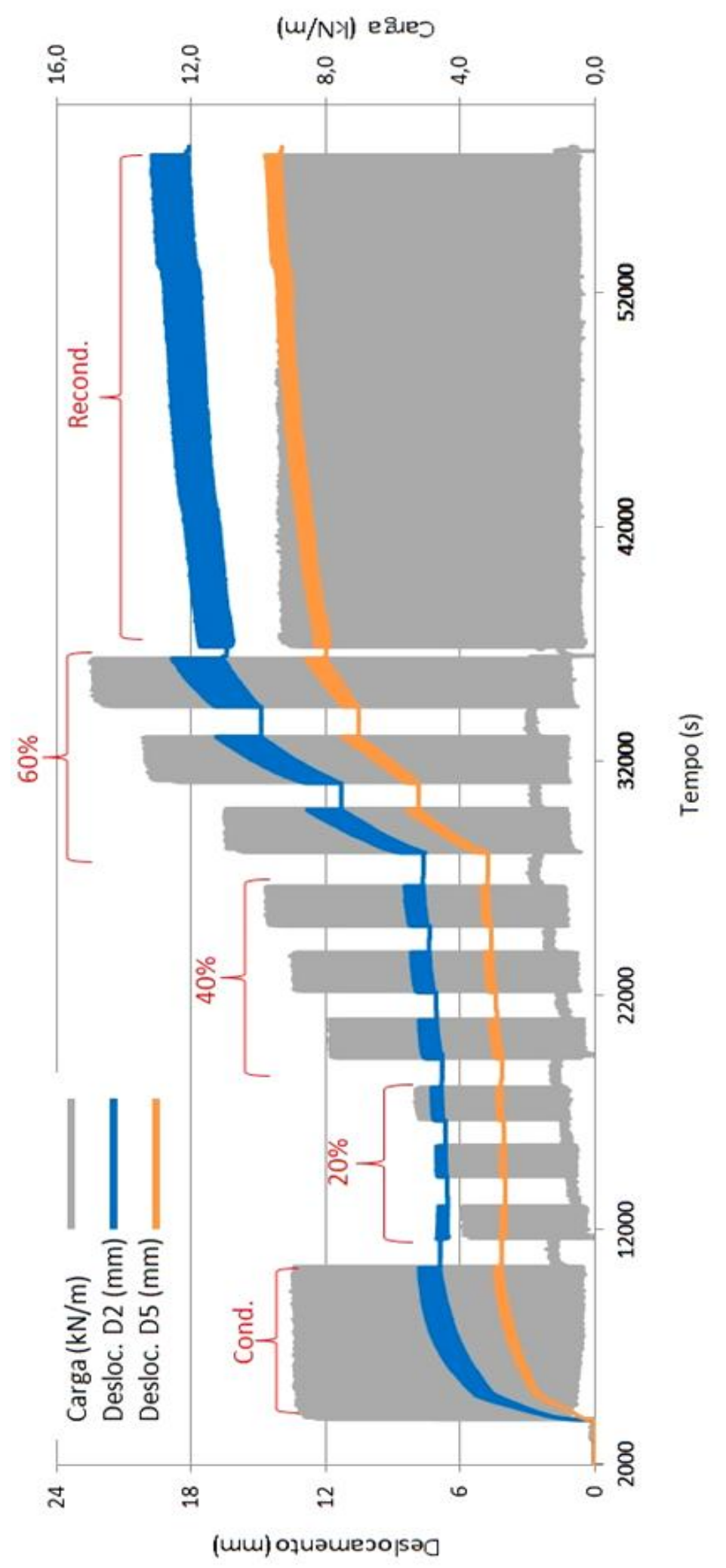

Figura 4.6 - Níveis de carregamento e deslocamento no ensaio cíclico com areia. 
Através de análise do gráfico percebe-se que no nível de condicionamento ocorrem grande parte dos deslocamentos registrados até o final do nível 2 (40\% da $F_{\text {máx }}$ ). No nível 1 (20\% da $F_{\text {máx }}$ ) de carregamento, os deslocamentos se mantém durante os 3 estágios de tensões confinantes. No nível $2\left(40 \%\right.$ da $\left.F_{\text {máx }}\right)$ de carregamento nota-se uma leve tendência de aumento gradativo dos deslocamentos. No nível 3 (60\% da $F_{\text {máx }}$ ) ocorre de maneira bem pronunciada a tendência ao aumento dos deslocamentos que levam ao arrancamento.

A série de ensaios de recondicionamento foi realizada para verificar se a tendência de aumento de deslocamentos obtido no nível 2 (40\% da $\left.F_{\text {máx }}\right)$ se estabilizaria. Percebeu-se que a tendência se mantém, não sendo registrados nem aumento nem diminuição do incremento de deslocamentos até o número de ciclos aplicado.

Na Figura 4.6, concentrando-se as análises no nível $2\left(40 \%\right.$ da $\left.F_{\text {máx }}\right)$ e tensão, $\sigma$, confinante de $40 \mathrm{kPa}$ é possível obter em detalhe a força, o deslocamento e a tensão no solo versus tempo de ensaio decorrido, as quais são apresentadas na Figura 4.7 a seguir.

Os comportamentos relativos à tensão de ciclagem, deslocamento da amostra e tensão total no solo mostradas na Figura 4.7 a seguir foram considerados padrões nos ensaios realizados com areia, representando valores médios e ligeiras variações de comportamento.

O gráfico mostra nível de carregamento aplicado estável e controlado dentro dos limites especificados do ensaio. Juntamente com aplicação da carga os transdutores de deslocamento registram deslocamentos de maiores magnitudes nas partes mais à frente da amostra (L1, D1 e D2) e magnitudes menores de deslocamentos na parte traseira da amostra (L2, D6 e D5), significando que o ancoramento da amostra induz deformações diferenciais na mesma. 


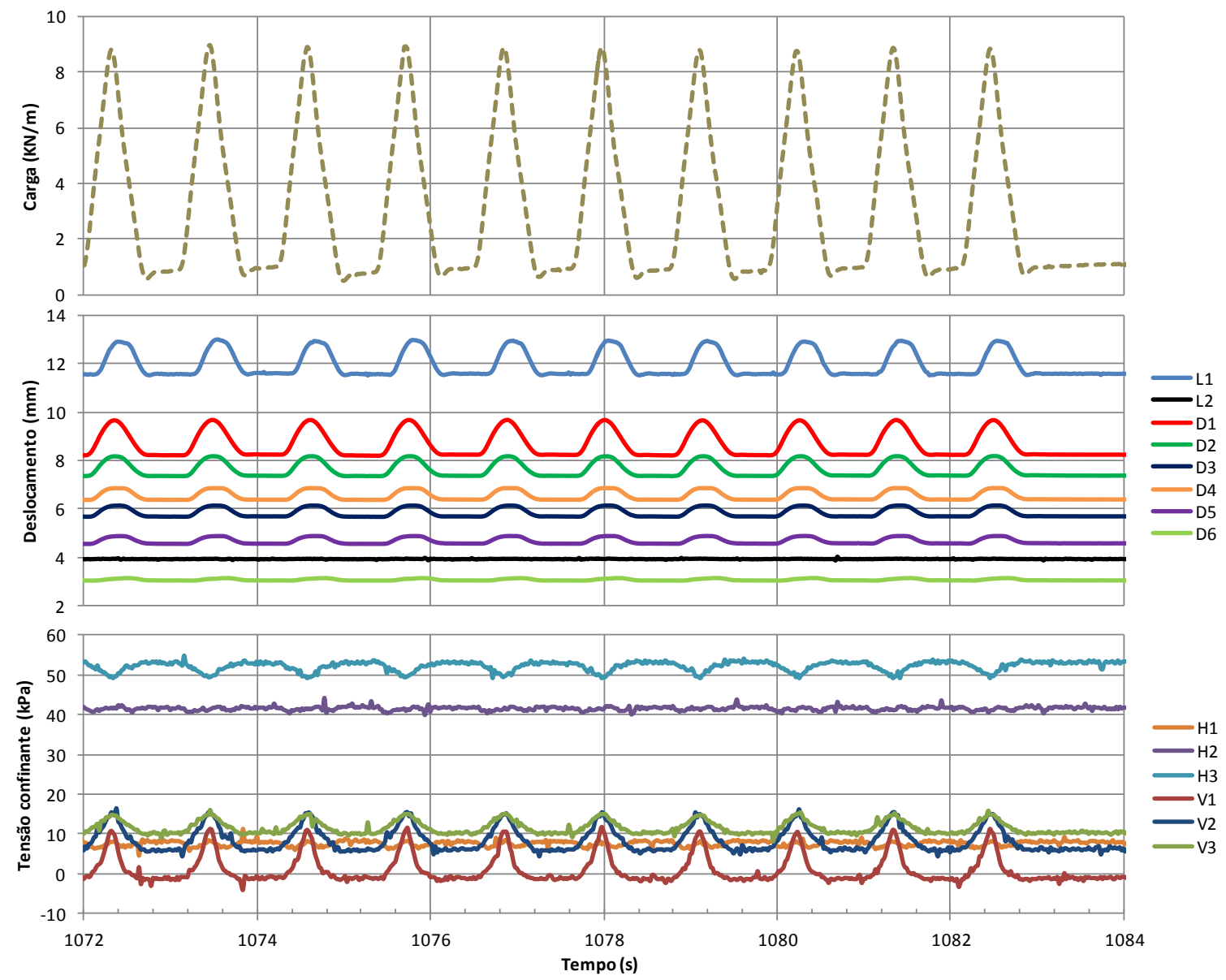

Figura 4.7 - Carga de ciclagem, deslocamento pontual e tensão total versus tempo com $40 \%$ da $F_{\text {máx }}$ e tensão, $\sigma$, de $40 \mathrm{kPa}$.

Através da análise dos gráficos e durante a realização dos ensaios pode-se perceber que entre os sensores utilizados na medição de deslocamentos, os sensores L1 e principalmente L2, apresentam resultados discrepantes em relação aos demais sensores, logo, os tratamentos seguintes referentes à ciclagem foram feitos baseado nos sensores D1 a D6.

A variação de tensões confinantes com a ciclagem ocorre de maneira semelhante à registrada nos ensaios de arrancamento estático, exceto que a ciclagem promove logo no início do conjunto de ciclagens o desancoramento gradativo do reforço, conforme mostrado pelas células H1, H2 e H3. As células mais próximas à frente $(\mathrm{H} 1$ e H2) apresentam pequena variação conforme o ensaio evolui, causado pelo desancoramento da parte frontal, deixando 
mais evidente a alteração de tensão na célula $\mathrm{H} 3$ posicionada na traseira da amostra, onde o ancoramento se mantém.

As células V1, V2 e V3 apresentaram menor variação com o andamento do ensaio, e mostram ainda a variação das tensões com a distância vertical em relação ao reforço. Foram registradas variações de tensões de magnitudes diferentes nestas células, ficando em cerca de $12 \mathrm{kPa}$ na mais próxima à manga e cerca de $6 \mathrm{kPa}$ na mais distante. A célula $\mathrm{V} 3$ apresenta desde o início das ciclagens pequena variação em relação ao seu valor antes do início do ensaio e mesmo em relação à ciclagem sua amplitude é menor, mostrando que a altura da caixa é suficiente para a dissipação das tensões no solo, com pouca influência das paredes da caixa no ensaio.

Analisando-se individualmente um ciclo completo de carga são registrados os deslocamentos ilustrados na Figura 4.8 a seguir, ao longo do reforço.

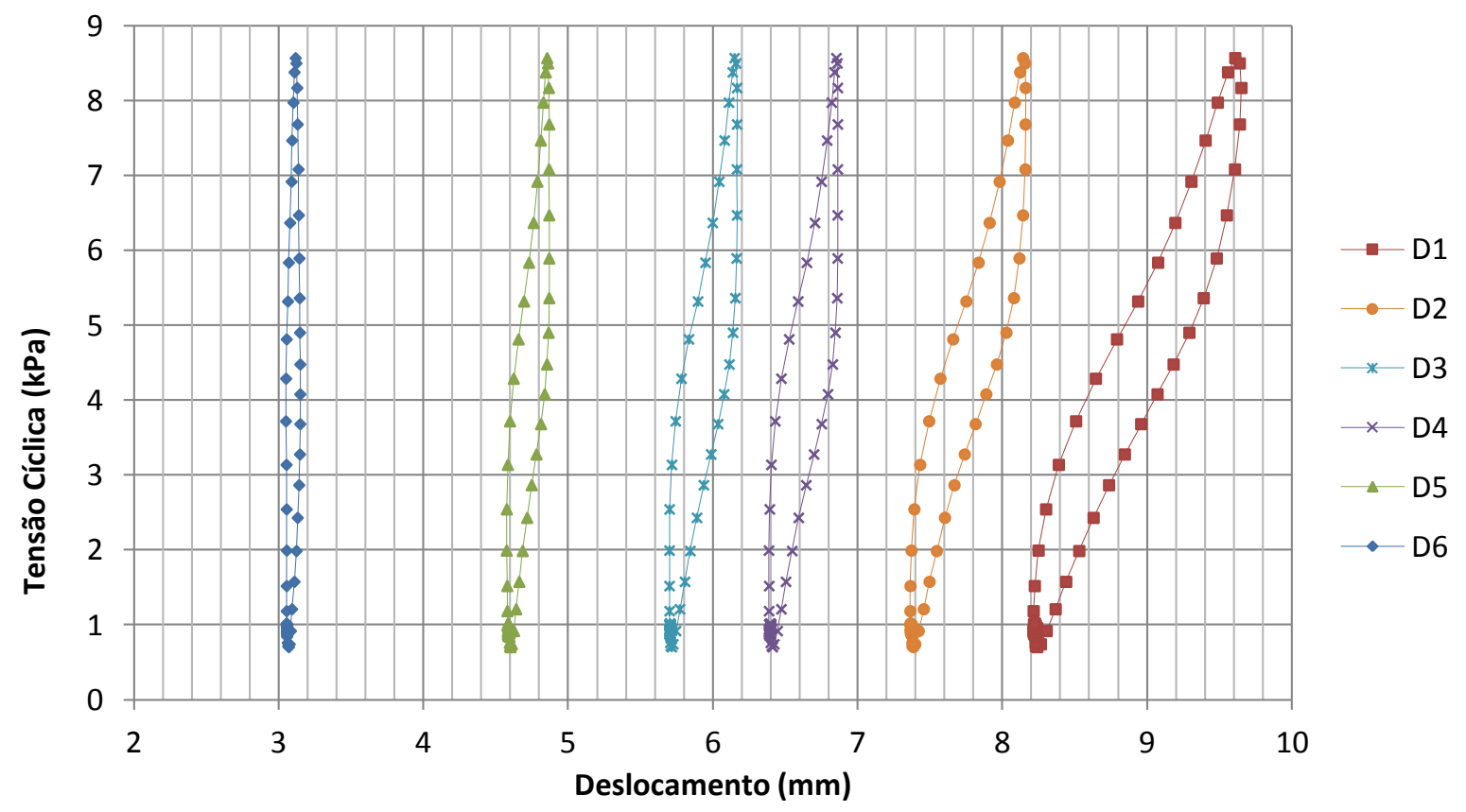

Figura 4.8 - Deslocamento registrado nos medidores D1 a D6 no último ciclo da tensão confinante de 40 $k P a$ e $40 \%$ da $F_{\text {máx }}$ em areia. 
Os sensores D3 e D4 que idealmente deveriam fornecer deslocamentos iguais pois eles ficam posicionados paralelos e na mesma distância da garra, como esquema da Figura 3.27, registraram alguma variação nos deslocamentos.

Tal gráfico mostra um aumento gradual de deslocamentos com a proximidade da aplicação de força (frente). Como já foi adotado por autores como Perkins (2004) e Holley (2009), resolveu-se representar os resultados por uma curva média de deslocamentos do corpo de prova, que permitiu gerar as curvas representadas na Figura 4.9 a seguir. Tal sequência de curvas é composta pela média de deslocamentos registrados nos sensores D1 ao D6, ilustrando desde o ciclo 1 ao ciclo 300 referentes ao carregamento de $40 \%$ da $F_{\text {máx }}$ e tensão, $\sigma$, de $40 k P a$.

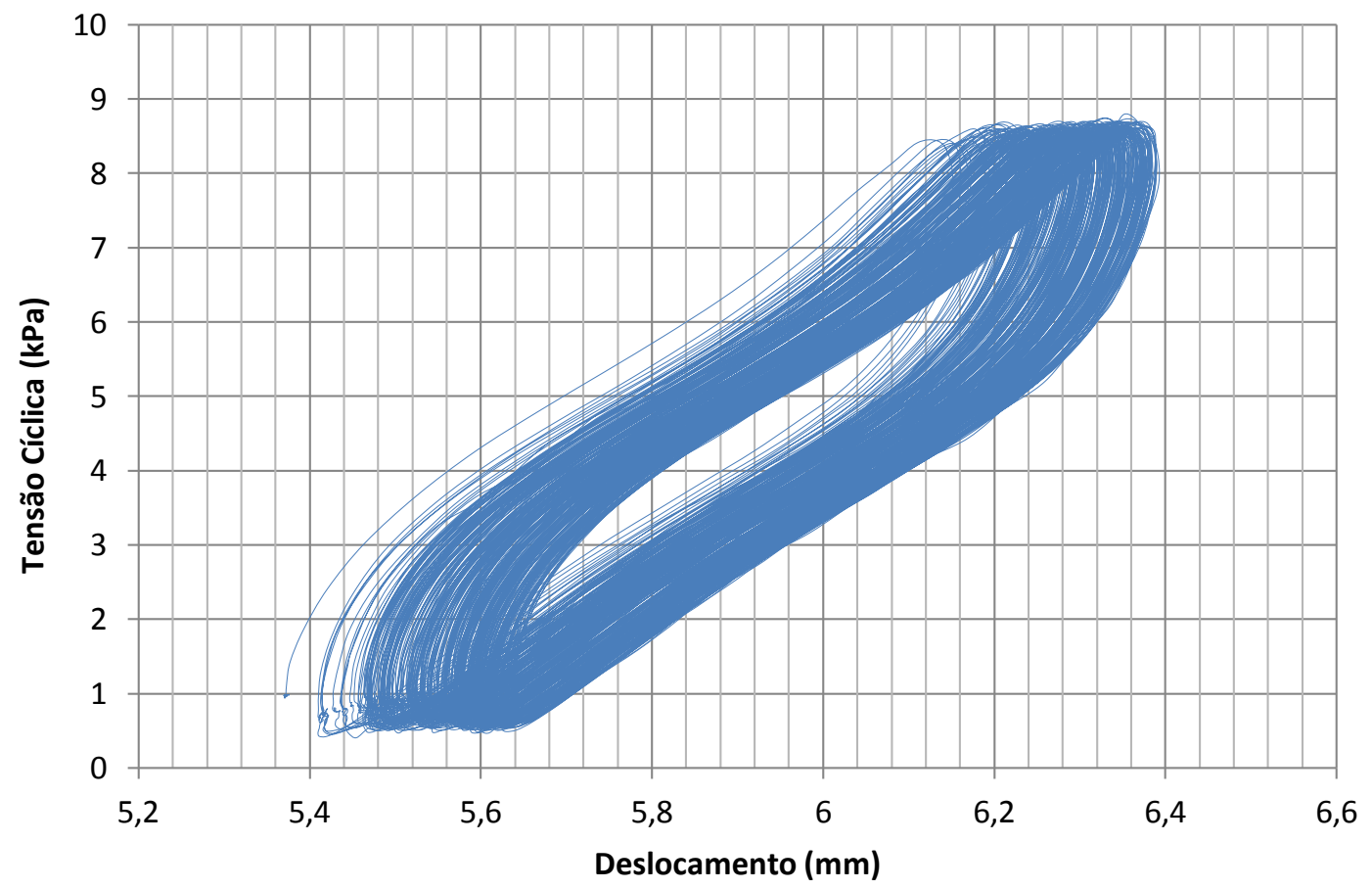

Figura 4.9 - Ciclagem completa com $40 \%$ da $F_{\text {máx }}$ e tensão, $\sigma$, de $40 \mathrm{kPa}$ em areia.

Na Figura 4.9 observa-se que no início da ciclagem ocorrem deslocamentos que crescem rapidamente nos primeiros ciclos e com a continuidade da ciclagem os 
deslocamentos ainda aumentam, porém a uma taxa inferior aos valores registrados no início e com tendência à estabilização.

Para cada carregamento (Nível 20, 40 e $60 \%$ da $F_{\text {máx }}$ ) são acumulados deslocamentos diferentes, assim como comportamentos médios de tensão-deslocamento em cada ciclo. Os últimos ciclos dos níveis 1,2 e $3\left(20,40\right.$ e $60 \%$ da $\left.F_{\text {máx }}\right)$, com tensão confinante de $40 \mathrm{kPa}$, estão ilustrados na Figura 4.10 seguir.

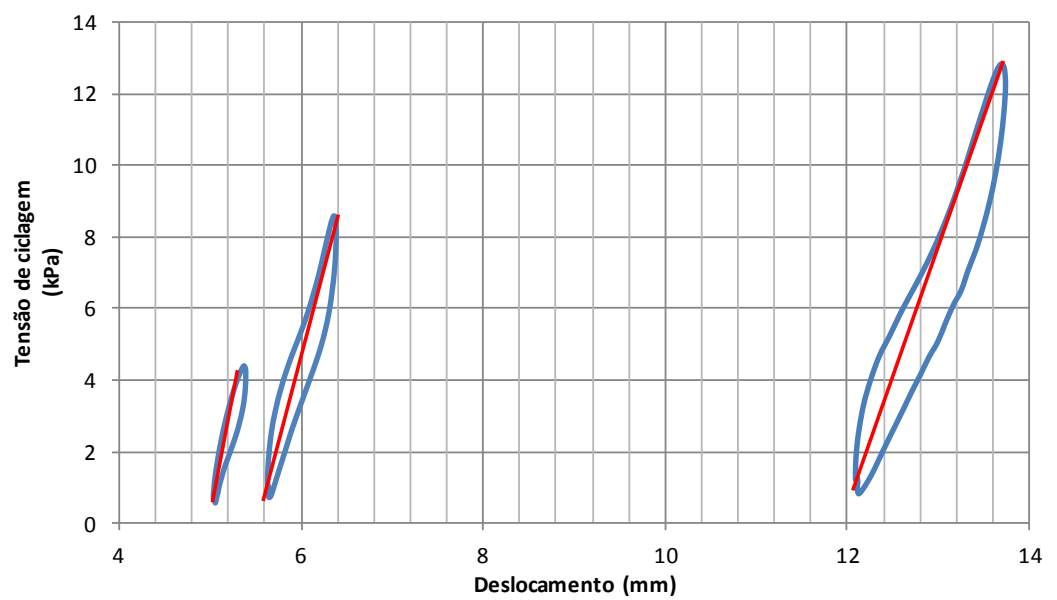

(a)

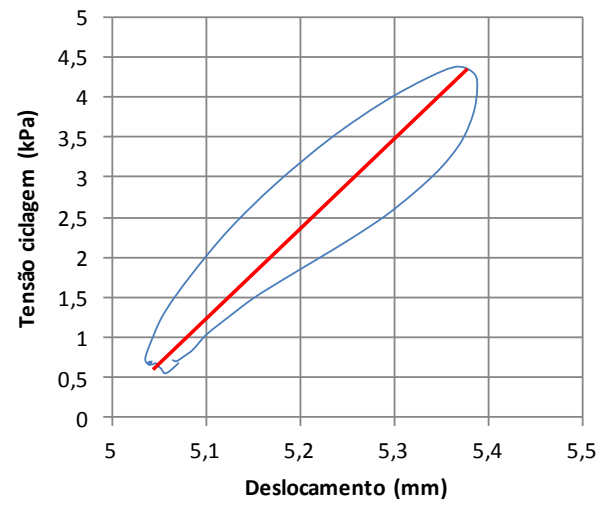

(b)

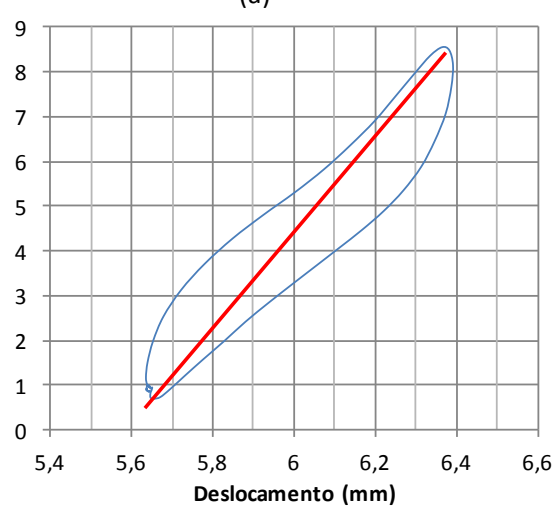

(c)

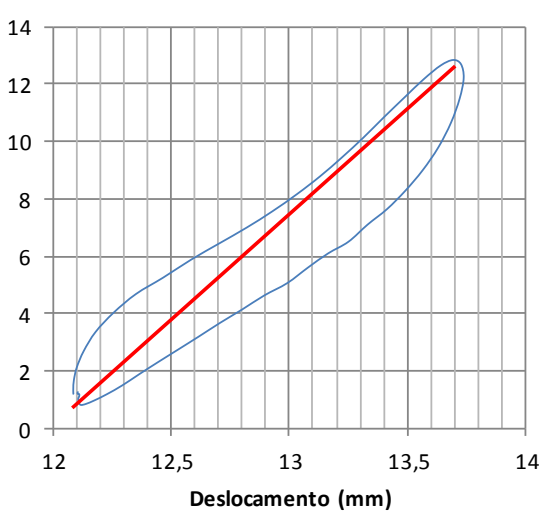

(d)

Figura 4.10 - (a) Ciclos de 20, 40 e $60 \%$ da $F_{\text {máx }}$ com tensão, $\sigma$, de $40 \mathrm{kPa}$; (b) Ciclo $20 \%$ da $F_{\text {máx }}$ e tensão, $\sigma$, de $40 \mathrm{kPa}$; (c) $40 \%$ da $F_{\text {máx }}$ e tensão, $\sigma$, de $40 \mathrm{kPa}$; (d) $60 \%$ da $F_{\text {máx }}$ e tensão, $\sigma$, de $40 \mathrm{kPa}$ e módulo de resiliência (reta) da areia. 
A ciclagem no nível de $20 \%$ da $F_{\text {máx }}$ gera amplitude de deslocamento da ordem de 0,35 mm enquanto no nível $40 \%$ da $F_{\text {máx }}$ a amplitude é de cerca de $0,75 \mathrm{~mm}$ e para o nível 60 $\% F_{\text {máx }}$ a amplitude aumenta consideravelmente para 1,60 $\mathrm{mm}$.

O cisalhamento do reforço na areia gera deformações no corpo de prova como se pode visualizar na Figura 4.11 a seguir.

A tração dos elementos longitudinais apresenta diferentes resultados ao longo do reforço, sendo que em certas ocasiões o elemento longitudinal se desprende dos elementos transversais (elementos de arraste), e em outras o elemento transversal é arrastado juntamente com o longitudinal, conforme o reforço é solicitado e sofre deformações.

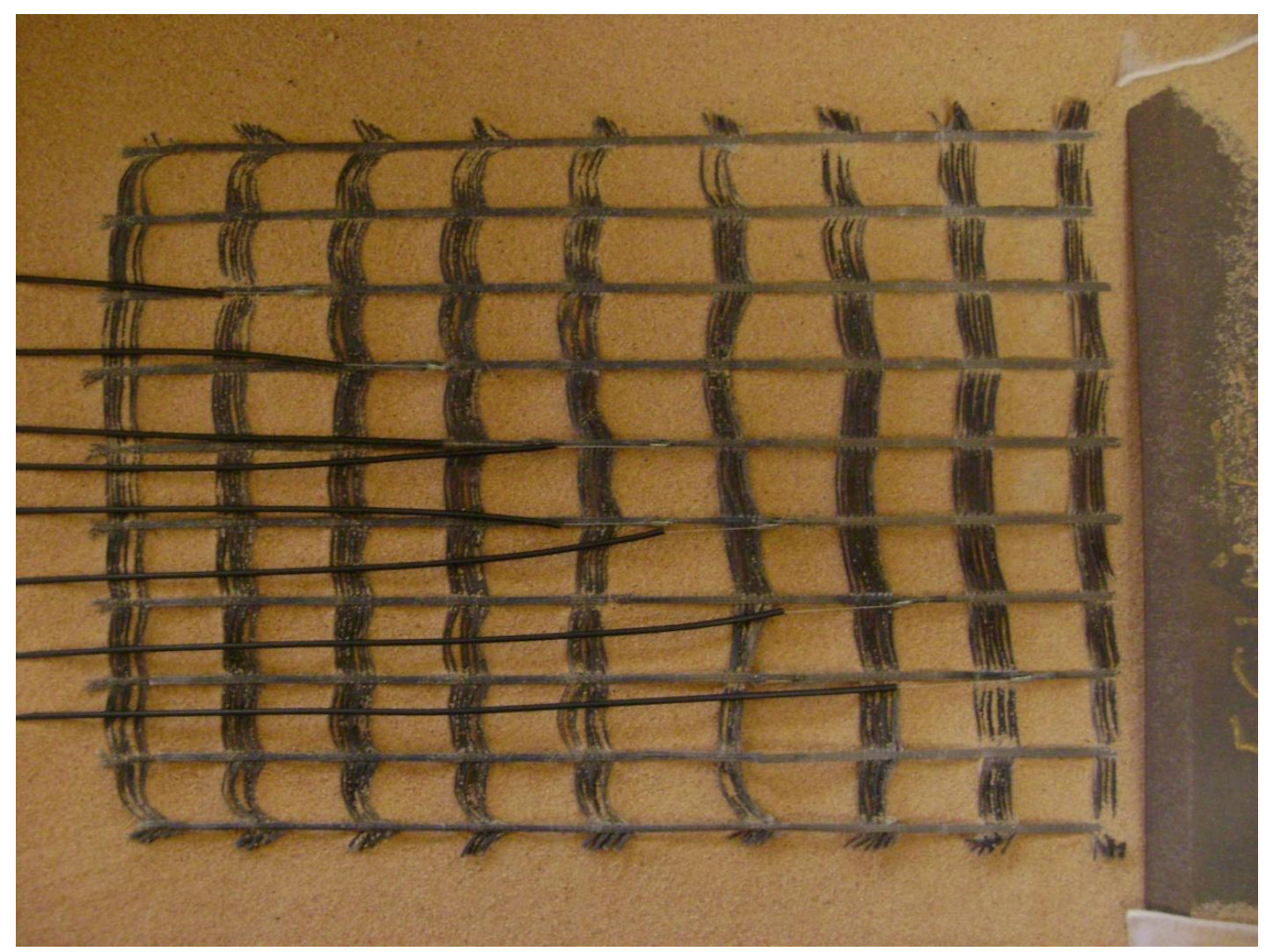

Figura 4.11 - Reforço cisalhado em areia (Ensaio CA2).

Durante os ensaios em areia era comum os elementos transversais, mais próximos à frente da caixa de ensaios, se deslocarem junto com o elemento longitudinal. Já na parte 
traseira da amostra, era comum os elementos transversais se soltarem gradativamente, passando a deslocar apenas o elemento longitudinal.

Por fim, a partir das diferentes informações apresentadas pode-se calcular o módulo de resiliência de cisalhamento de interface, relação entre a variação de deslocamento versus tensão de cada ciclo, calculado com a Equação 2.14 anterior. A Figura 4.12 a seguir mostra a variação do módulo de cisalhamento com o nível de tensão, $\tau$, aplicado no ensaio em areia.

O comportamento mostrado no gráfico, assim como a magnitude de valores fica aquém dos valores normalmente encontrados na literatura referente a materiais considerados mais rígidos, com composição polimérica diferente e menores comprimentos de ancoragem. Tais variações possivelmente ocorrem devido à rigidez do material utilizado nesta pesquisa, que apresenta maior deformabilidade, e do maior comprimento do corpo de prova.

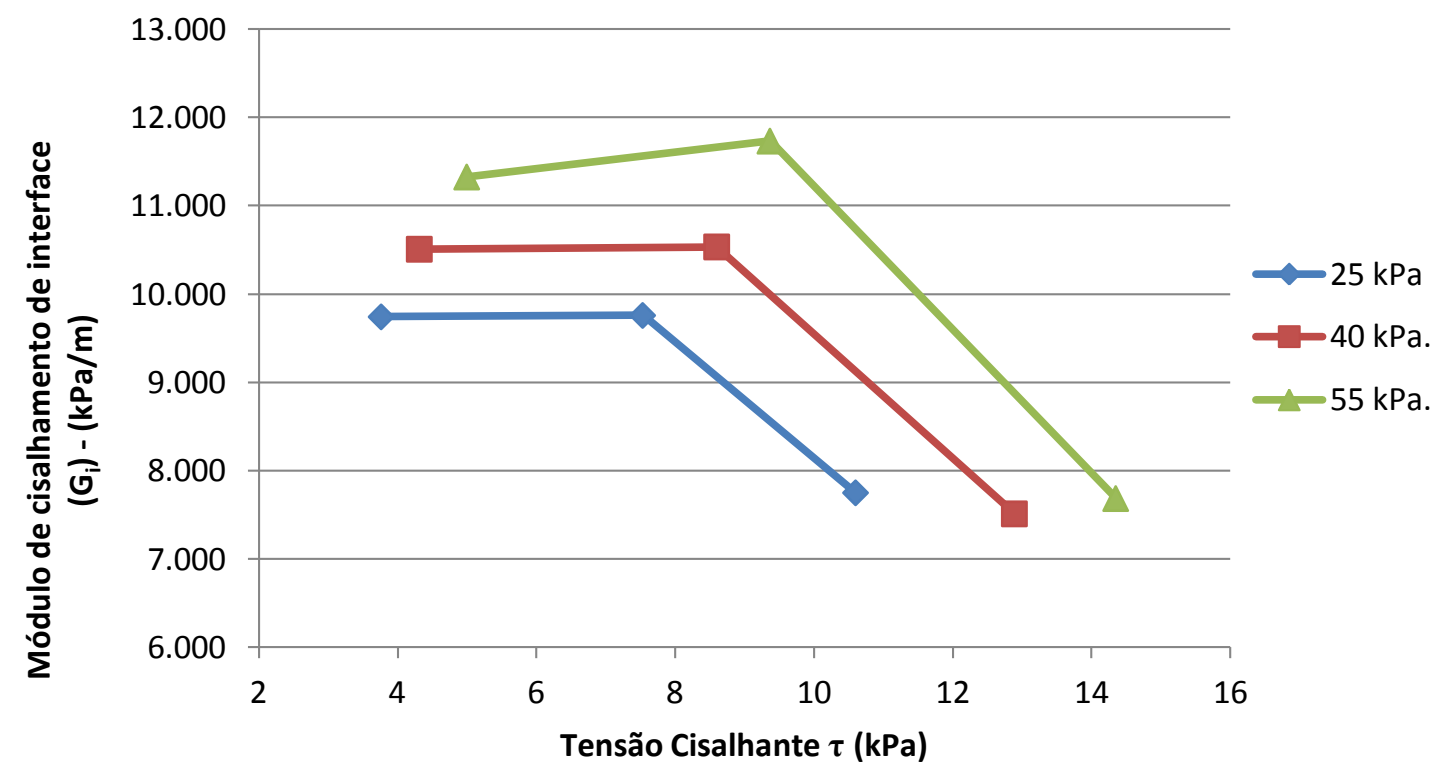

Figura 4.12 - Módulo de resiliência de interface $\left(G_{i}\right)$ versus Tensão cisalhante $(\tau)$ em areia.

Este fato implica que o módulo resiliente medido corresponde, provavelmente a um nível de deslocamento elevado. Como se sabe, os módulos de elasticidade para pequenas deformações atingem seus valores máximos e rapidamente se degradam com o aumento das 
deformações. Esta pode ser a principal razão para a discrepância observada com relação aos ensaios de Perkins (2004) e Holley (2009) que utilizaram corpos de prova com cerca de 80 $m m$ de comprimento e geogrelhas de Polipropileno que apresentam deformabilidade inferior à utilizada nesta pesquisa, resultando em valores de módulo de resiliência cerca de 10 vezes os obtidos nesta pesquisa.

\section{2 $\underline{\text { Silte }}$}

\subsubsection{Arrancamento Silte}

Foram realizados ensaios de arrancamento mantendo-se as características de geometria do reforço e montagem da caixa, variando-se apenas a tensão confinante $\sigma$.

Os ensaios de arrancamento deste grupo de ensaios geraram as curvas força versus deslocamento expostas a seguir (Figura 4.13), referentes às tensões confinantes $\sigma$ de 25, $40 \mathrm{e}$ $55 \mathrm{kPa}$.

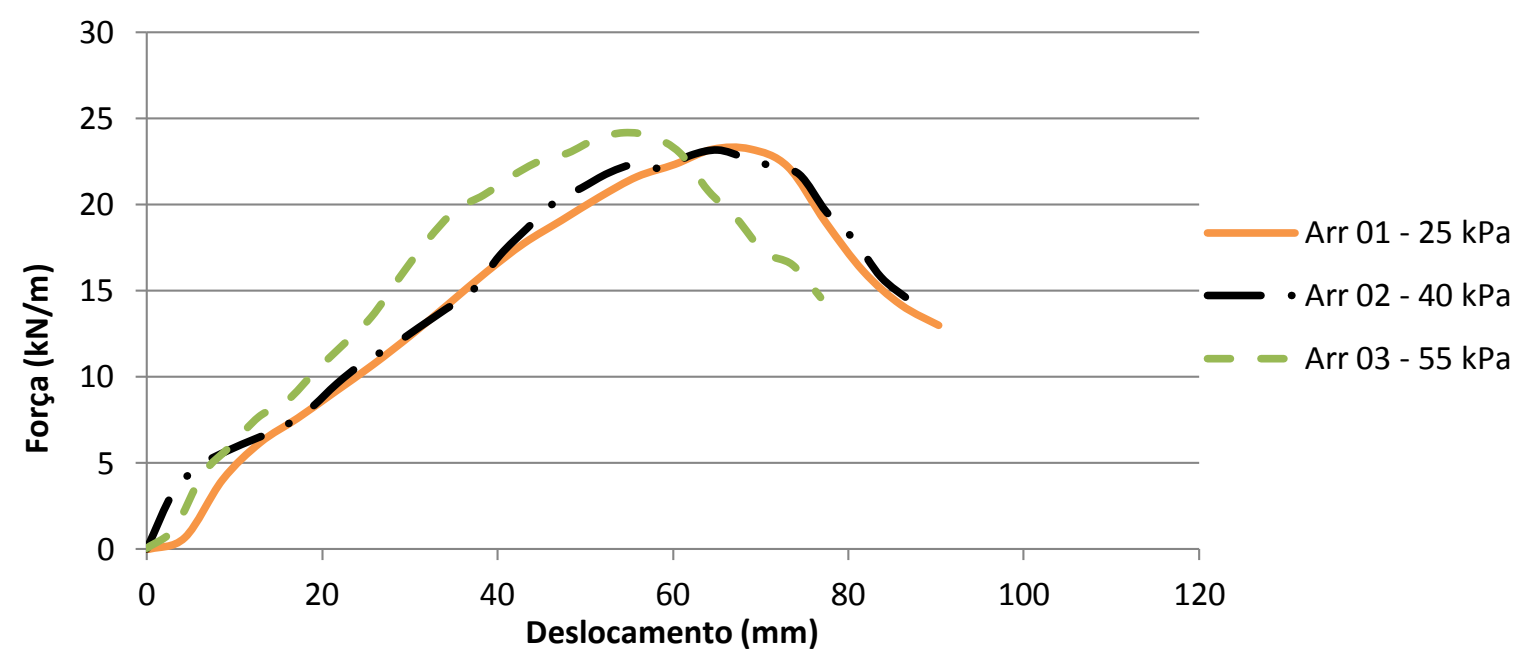

Figura 4.13 - Curvas força de arrancamento versus deslocamento da garra para silte. 
Os ensaios mostraram que mesmo com o aumento da tensão confinante até os níveis ensaiados não houve aumento na resistência máxima ao arrancamento, apenas uma ligeira diminuição no deslocamento máximo no ensaio com tensão confinante maior ( $\sigma$ de $55 \mathrm{kPa}$ ).

Estes ensaios de arrancamento no silte também foram instrumentados segundo o sistema B descrito anteriormente quanto a deslocamentos e tensões horizontais e verticais no entorno do reforço, e, assim obtiveram-se as curvas de força versus deslocamento em diversas posições da geogrelha, como se ilustra na Figura 4.14 a seguir, juntamente com um esquema de posicionamento dos transdutores de deslocamento.

O gráfico mostra o comportamento esperado e semelhante ao da areia, onde inicialmente ocorrem deslocamentos nos elementos mais próximos à aplicação da força cisalhante (frente), e com o aumento da força as partes mais ancoradas (traseira) da amostra são solicitadas e apresentam deslocamento gradativo.

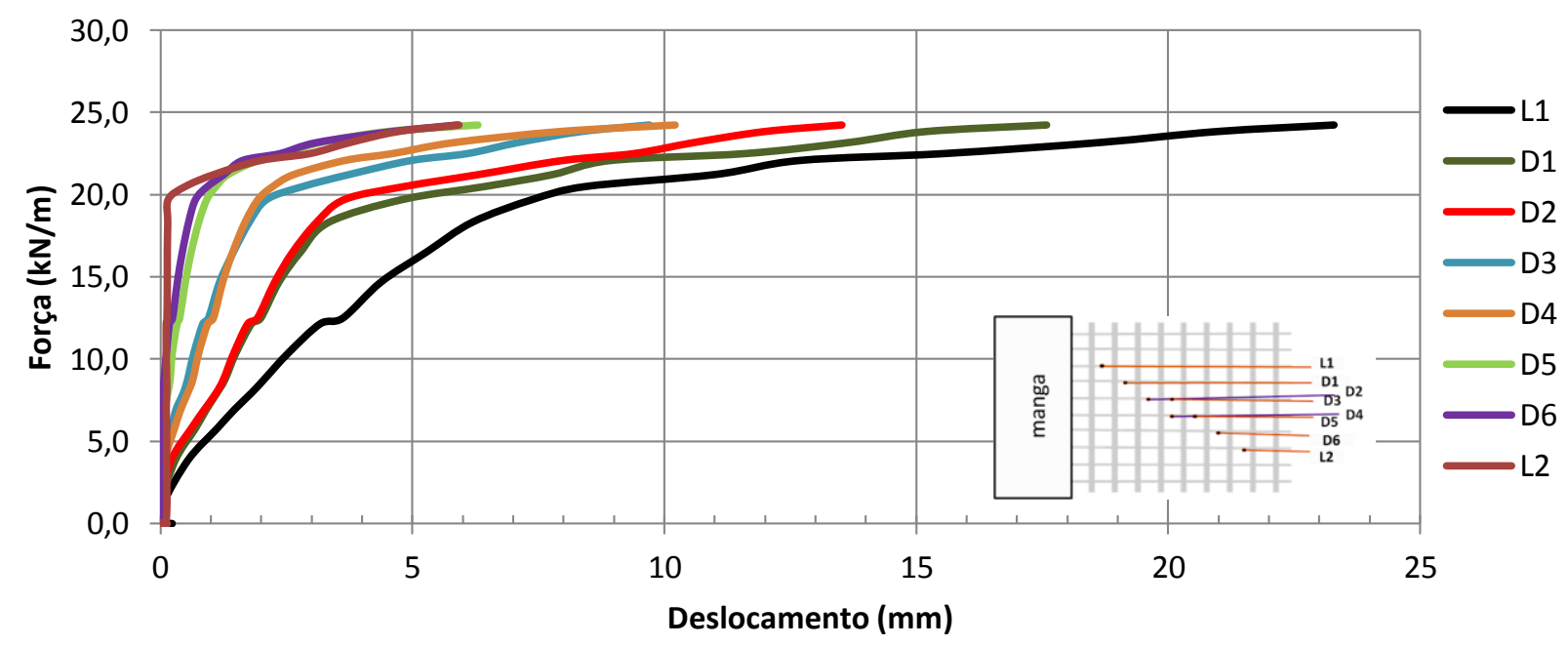

Figura 4.14 - Deslocamento dos sensores ao longo da amostra durante ensaio de arrancamento em silte com tensão, $\sigma$, de $55 \mathrm{kPa}$ (Ensaio AC3).

O comportamento para o restante dos ensaios de arrancamento apresentou pequena variação na ordem da solicitação dos elementos (L1, D1, D2...) com o andamento do ensaio, 
mostrando um fato coerente pois a amostra fica ancorada em um solo aparentemente mais rígido. Pôde-se perceber que o reforço se desloca em pequenos blocos ou seções aleatórias, fazendo com que ocorram deslocamentos semelhantes em locais com distâncias diferentes em relação à manga. Tal comportamento pode ser visualizado através da proximidade das curvas dos sensores D1 e D2, D3 e D4, D5 e D6 (Figura 4.14) que apresentam posicionamento diferente no corpo de prova, exceto D3 e D4 que ficam paralelos, mas forneceram comportamento força-deslocamento semelhantes.

No silte também foram utilizadas as medidas locais ao longo do corpo de prova, para determinar os deslocamentos em função da distância da aplicação da força de arrancamento, a partir da manga, para cada nível de força aplicada. Estes resultados encontram-se na Figura 4.15 a seguir.

Estes valores de deslocamento possibilitam estimar qual o comprimento do reforço solicitado em relação a cada força de arrancamento.

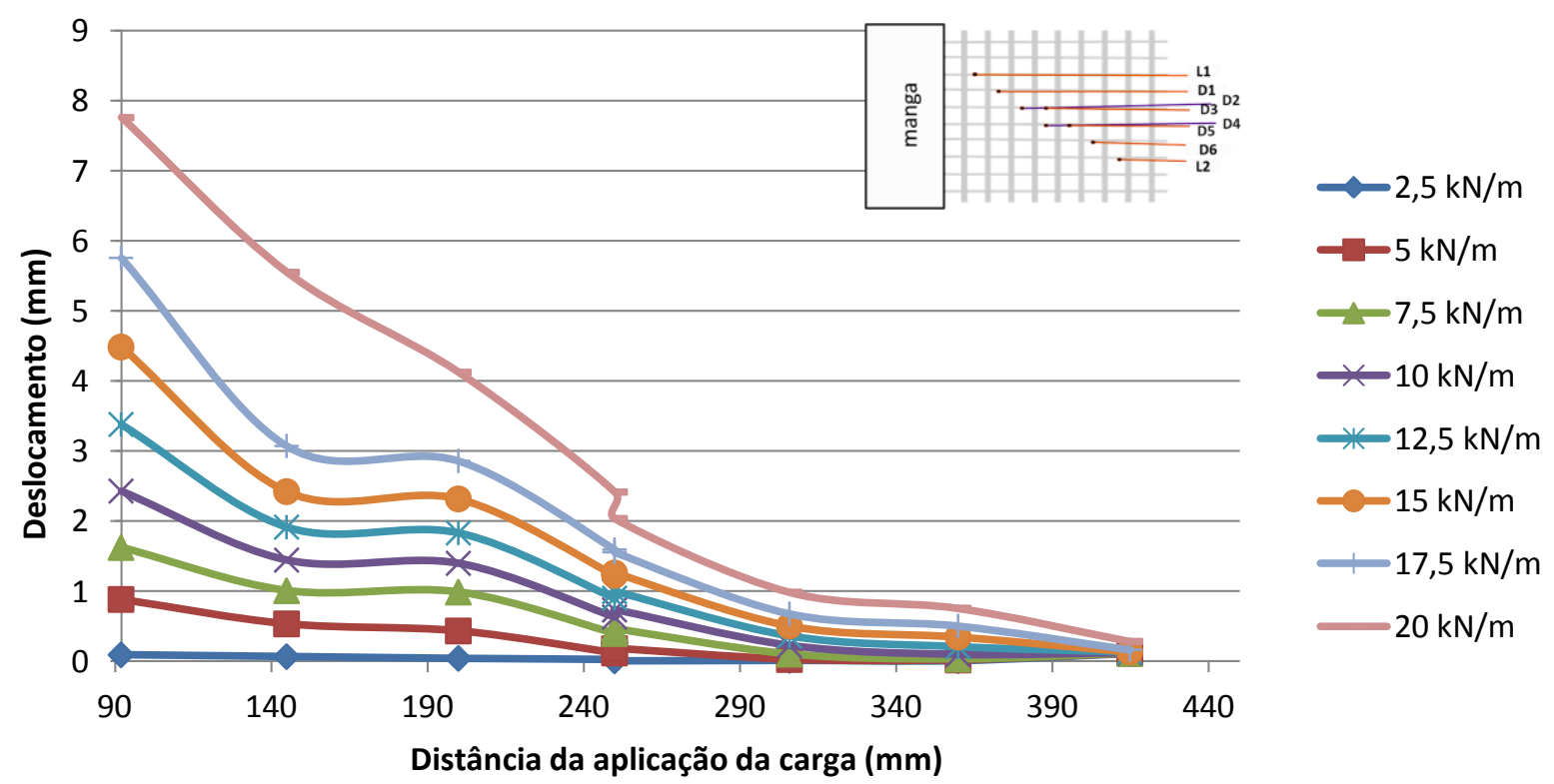

Figura 4.15 - Solicitações ao longo do corpo de prova em ensaio de arrancamento com tensão, $\sigma$, de $55 \mathrm{kPa}$ (Ensaio AC3). 
$\mathrm{Na}$ Figura anterior nota-se que com força de $2,5 \mathrm{kN} / \mathrm{m}$ ocorre solicitação de cerca de $150 \mathrm{~mm}$ de comprimento de amostra, com força de $5 \mathrm{kN} / \mathrm{m}$ a solicitação aumenta para cerca de $290 \mathrm{~mm}$. Com força de $10 \mathrm{kN} / \mathrm{m}$ a amostra solicita mais de $360 \mathrm{~mm}$, e a partir desta força o reforço é integralmente solicitado, e seu deslocamento apresenta aumento gradativo e proporcionalmente maior na parte da frente do corpo de prova. Os deslocamentos na parte traseira do corpo de prova são desprezíveis até o ponto de carga máxima ao arrancamento, onde ocorre aumento abrupto dos deslocamentos em todos os pontos da amostra, obtendo-se maior deformabilidade do reforço neste solo.

O acompanhamento das tensões normais durante os ensaios de arrancamento permitiu elaborar o gráfico da Figura 4.16 a seguir. Em todos os ensaios de arrancamento em silte foram obtidos comportamentos semelhantes aos exibidos na Figura 4.16 a seguir.

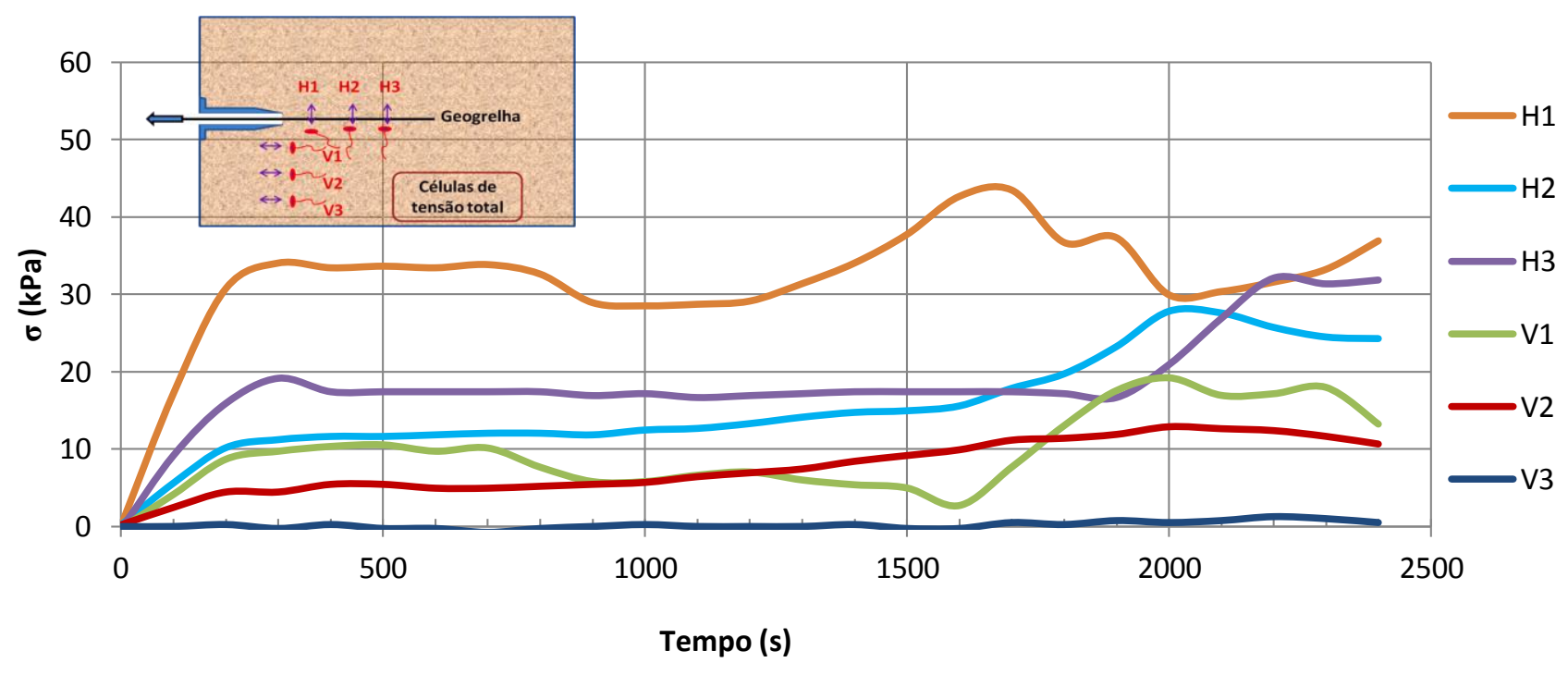

Figura 4.16 - Arrancamento com tensão, $\sigma$, de 40 kPa em silte (Ensaio AC2).

Assim como na areia, no silte foram registradas ocorrências de tensões diferentes em regiões diferentes da caixa de ensaios. Em regiões próximas e distantes da manga são 
registradas tensões iniciais maiores do que em regiões intermediárias, comprovando a influência da mesma nas tensões que chegam efetivamente ao solo.

Nos ensaios de arrancamento as células de tensão total horizontais e verticais eram posicionadas à mesma distância em relação à manga, nos locais pré-determinados ilustrados na Figura 3.9, porém, foram notadas variações nas tensões iniciais diferentes entre os ensaios, provavelmente devido ao desconfinamento dos locais de instalação das células e posterior compactação pontual dos locais, que poderiam ocorrer de forma diferente à utilizada no restante da caixa de ensaios. O aumento das tensões registrados nas células após o início dos ensaios ocorreu de maneira semelhante durante os ensaios com tensões $\sigma$ de 25,40 e $55 \mathrm{kPa}$.

Conforme o ensaio é realizado ocorre variação das tensões de modo que o sensor posicionado de forma horizontal (leituras de tensão vertical) mais próximo à aplicação de carga (à frente) H1 sofre ligeira queda de tensões, provavelmente causada por um desconfinamento da parte frontal do reforço, que logo se compensa e os sensores H1 e H2 passam a apresentar elevação das tensões conforme o material é tracionado, seguido pelo aumento no sensor posicionado mais ao final da ancoragem (traseira - H3). Logo em seguida ao aumento de tensão ocorre sua diminuição, retornando ao valor inicial. Tal fato provavelmente ocorre pois o início da mobilização da amostra aumenta a tensão ao seu redor, que sofre ligeiro desconfinamento e consequentemente expande, e, logo ocorre redistribuição da carga ao longo do comprimento ancorado da amostra.

Os sensores posicionados de forma vertical (leituras de tensão horizontal) também registraram a alteração de tensões com o arrancamento da amostra, na direção vertical. Verifica-se que o sensor V1 sofre alteração com o início do ensaio, e conforme o corpo de prova é tracionado é registrado aumento de $15 \mathrm{kPa}$. A célula V2 apresenta aumento menos pronunciado de $7 \mathrm{kPa}$ e a célula $\mathrm{V} 3$ mostra que praticamente não há alteração de tensões a 
cerca de $150 \mathrm{~mm}$ da distância vertical do reforço. No restante dos ensaios as células de tensão total foram trocadas aleatoriamente, porém, mantidas nas mesmas posições em relação à amostra, e foi observado comportamento semelhante para os ensaios de arrancamento neste solo.

\subsubsection{Ciclagem Silte}

Como os valores de força máxima dos ensaios de arrancamento ficaram muito próximos, para estabelecer os níveis de ciclagem foi considerada uma força média destes ensaios, utilizando-se forças correspondentes a 20,40, 60 e $80 \%$ da força máxima de arrancamento. Puderam-se utilizar estes quatro níveis de força de arrancamento, pois se percebeu que o ancoramento do reforço pelo solo se mantinha com a ciclagem, devido ao nível de interação deste solo coesivo com o reforço, aos relativamente baixos níveis de deslocamento registrados e a pouca perda de material com a ciclagem, possibilitando a realização adicional da ciclagem com $80 \%$ da $F_{\text {máx }}$.

Baseado na norma ASTM 7499 (2009) ao início dos ensaios eram aplicados 1000 ciclos para estabilização do conjunto com carga cíclica e tensão confinante média em relação à programação inicial de carregamentos aplicados, que para o silte foi de $40 \%$ da $F_{\text {máx }}$ e tensão confinante de $40 \mathrm{kPa}$. Foram utilizados estes parâmetros pois somente após este estágio de condicionamento e das ciclagens nos níveis 1,2 e 3 foi verificada a possibilidade de realização de um nível adicional (nível $4-80 \%$ da $F_{\text {máx }}$ ).

Após os ciclos de condicionamento, o procedimento de ensaios era o mesmo utilizado para a areia, iniciando a ciclagem pelo carregamento de menor intensidade (20\% da $F_{\text {máx }}$ ) com tensão confinante de $25 \mathrm{kPa}$ e nos estágios seguintes, mantida constante a força de $20 \%$ da $F_{\text {máx }}$, as tensões confinantes eram aumentadas para 40 e $55 \mathrm{kPa}$. Finalizada esta série de 
ensaios com nível de $20 \%$ da $F_{\text {máx }}$ o ensaio prosseguia repetindo-se o procedimento de aumento da confinante para os níveis de Força de Arrancamento de 40, 60 e $80 \%$ da $F_{\text {máx }}$, representados na Figura 4.17 a seguir.

Para o silte também foi realizada a série de ciclagem de recondicionamento, onde foram aplicados 3000 ciclos com carregamento e tensão confinante iguais às do nível 3 (60 \% da $F_{\text {máx }}$ com tensão confinante, $\sigma$, de $40 \mathrm{kPa}$ buscando a verificação da estabilização dos deslocamentos.

São representados na Figura 4.17 a seguir os níveis de carregamentos aplicados e os deslocamentos registrados nos transdutores de deslocamentos D1 e D6 posicionados próximo à aplicação de força (à frente) e mais ancorados (atrás), respectivamente, buscando representar o comportamento em termos de deslocamentos em diferentes pontos do corpo de prova.

O gráfico a seguir (Figura 4.17) mostra ainda o deslocamento médio do reforço em cada nível de solicitação, tendo em vista que os sensores (D1 e D6) encontram-se a posições equidistantes da frente e da traseira do corpo de prova, respectivamente.

Assim como na areia, pode-se perceber através da análise do gráfico que no nível de condicionamento são adquiridos grande parte dos deslocamentos registrados até o final do nível 2 (40\% da $\left.F_{\text {máx }}\right)$. No nível 1 (20\% da $F_{\text {máx }}$ ) e nível 2 (40\% da $F_{\text {máx }}$ ) de carregamento os deslocamentos se mantém durante os 3 estágios de tensões confinantes. No nível 3 (60 \% da $\left.F_{\text {máx }}\right)$ de carregamentos nota-se tendência de aumento gradativo dos deslocamentos. No nível $4\left(80 \%\right.$ da $\left.F_{\text {máx }}\right)$ ocorre de maneira bem pronunciada o aumento dos deslocamentos que ao final levam ao arrancamento. 


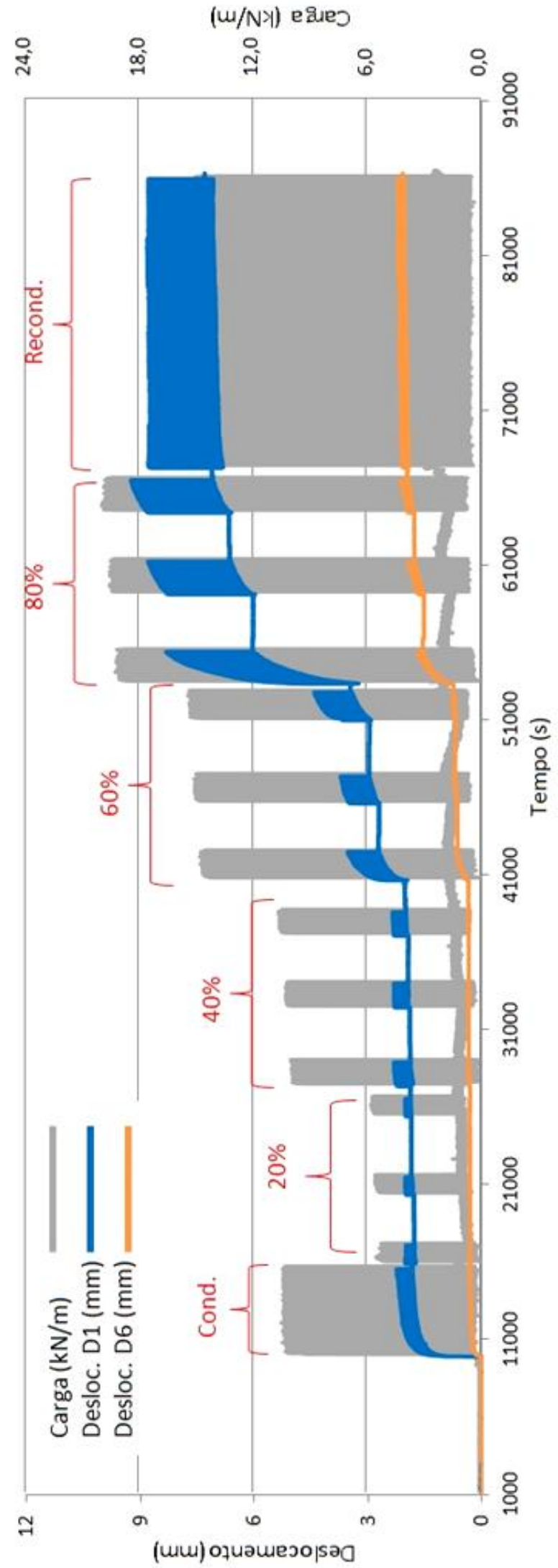

Figura 4.17 - Níveis de carregamento e deslocamento em silte. 
A série de recondicionamento no silte buscou verificar a estabilidade de deslocamentos do nível 3 (60\% da $F_{\text {máx }}$ ), e percebeu-se que a tendência de aumento de deslocamentos cessa, estabilizando-se primeiro o nível de deslocamento máximo e com cerca de 2000 ciclos se estabiliza o deslocamento mínimo, referente à carga de assentamento.

Ao se concentrar as análises no nível $3\left(60 \%\right.$ da $\left.F_{\text {máx }}\right)$ e tensão confinante de $40 \mathrm{kPa}$ da Figura 4.17 é possível obter em detalhe o comportamentos de tensão cisalhante, o deslocamento e a tensão no solo versus tempo de ensaio decorrido, representados na Figura 4.18 a seguir.

Estes comportamentos referentes à tensão de ciclagem, deslocamento da amostra e tensão total no solo mostrados na Figura 4.18 a seguir foram considerados típicos nos ensaios realizados com silte, representando valores médios do comportamento deste solo.

O gráfico mostra nível de carregamento aplicado estável e controlado dentro dos limites especificados no ensaio. Juntamente com a aplicação da carga os transdutores de deslocamento registram deslocamentos de maiores magnitudes nas partes mais à frente da amostra (L1, D1 e D2) e magnitudes menores de deslocamentos na parte traseira da amostra (L2, D6 e D5), significando que o ancoramento da geogrelha condiciona à deformações na mesma.

Pode-se perceber através de análise dos gráficos que os sensores L1 e principalmente L2 utilizados na medição de deslocamentos apresentam certo ruído elétrico, além de menor precisão, logo, os tratamentos seguintes referentes à ciclagem foram feitos baseado nos sensores D1 a D6. 


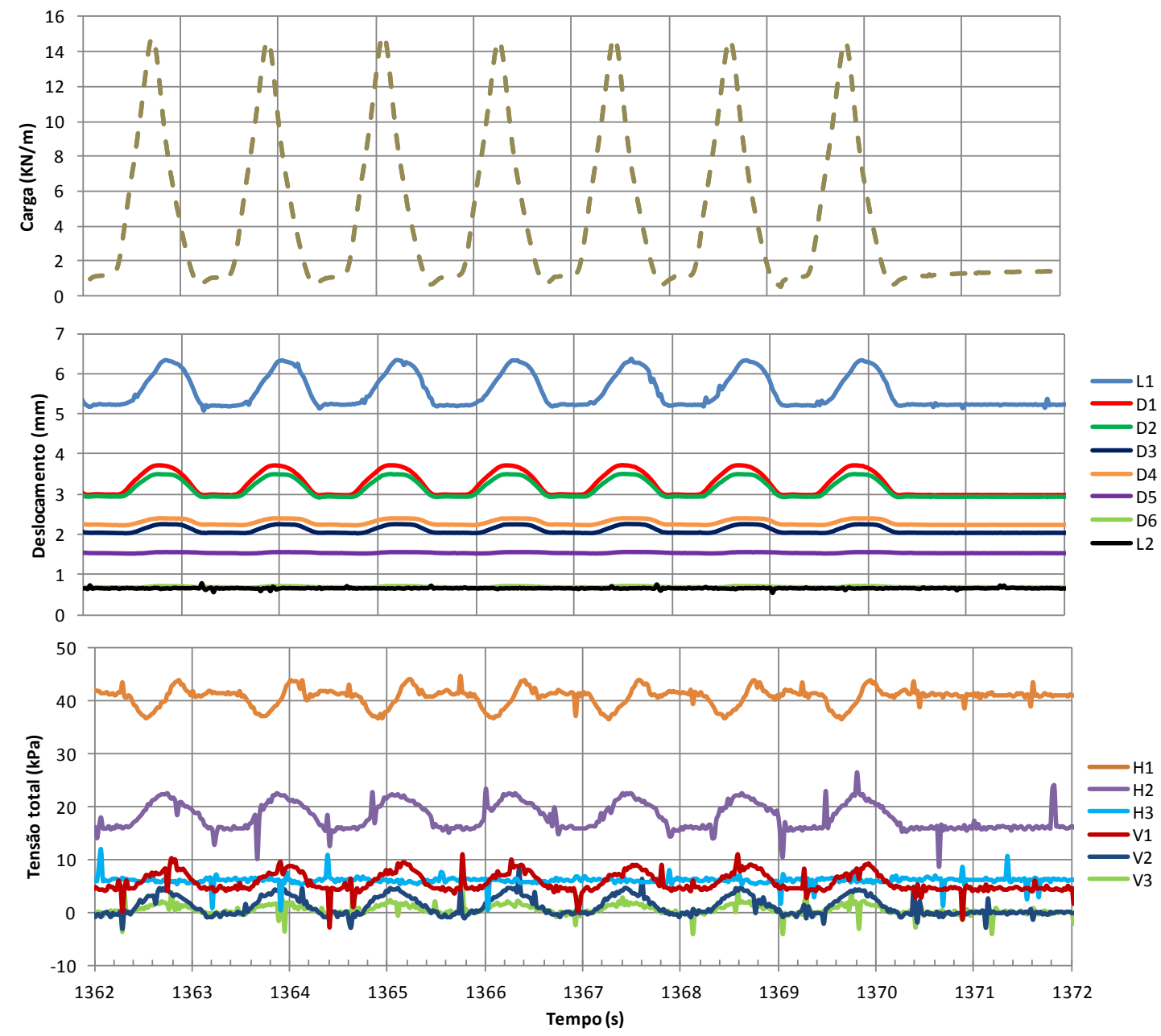

Figura 4.18 - Carga de ciclagem, deslocamento pontual e tensão total versus tempo no ensaio com silte, Força de $60 \%$ da $F_{\text {máx }}$ e tensão, $\sigma$, de $40 \mathrm{kPa}$.

A variação de tensões com a ciclagem ocorre de maneira semelhante à registrada nos ensaios de arrancamento, exceto que o sensor H1 apresenta variação de carga cíclica inferior à esperada, provavelmente devido a uma leve movimentação de solo ao seu redor, reduzindo sua ancoragem. No sensor $\mathrm{H} 2$ o deslocamento cíclico apresenta a maior amplitude, mostrando que a geogrelha ainda se encontra bem confinada neste ponto e provavelmente é o local onde está sendo mais solicitada. Esta conclusão pode ser comprovada ainda pela estabilidade do sensor H3, que não mostra sinais de variação de tensões causadas pela ciclagem, sugerindo que houve pouca movimentação de solo nesta área. 
As células V1, V2 e V3 fornecem as tensões ao longo da vertical e registram variações de tensões de cerca de $5 \mathrm{kPa}$ na mais próxima à manga e cerca de $2 \mathrm{kPa}$ na mais distante. A célula V3 apresenta desde o início das ciclagens pequena variação em relação ao seu valor antes do início do ensaio e mesmo em relação à ciclagem sua amplitude é menor, indicando que a altura da caixa é suficiente para a dissipação das tensões no solo, com pouca influência das paredes da caixa no ensaio.

Analisando-se individualmente um ciclo completo de carga são registrados os deslocamentos ilustrados na Figura 4.19 a seguir.

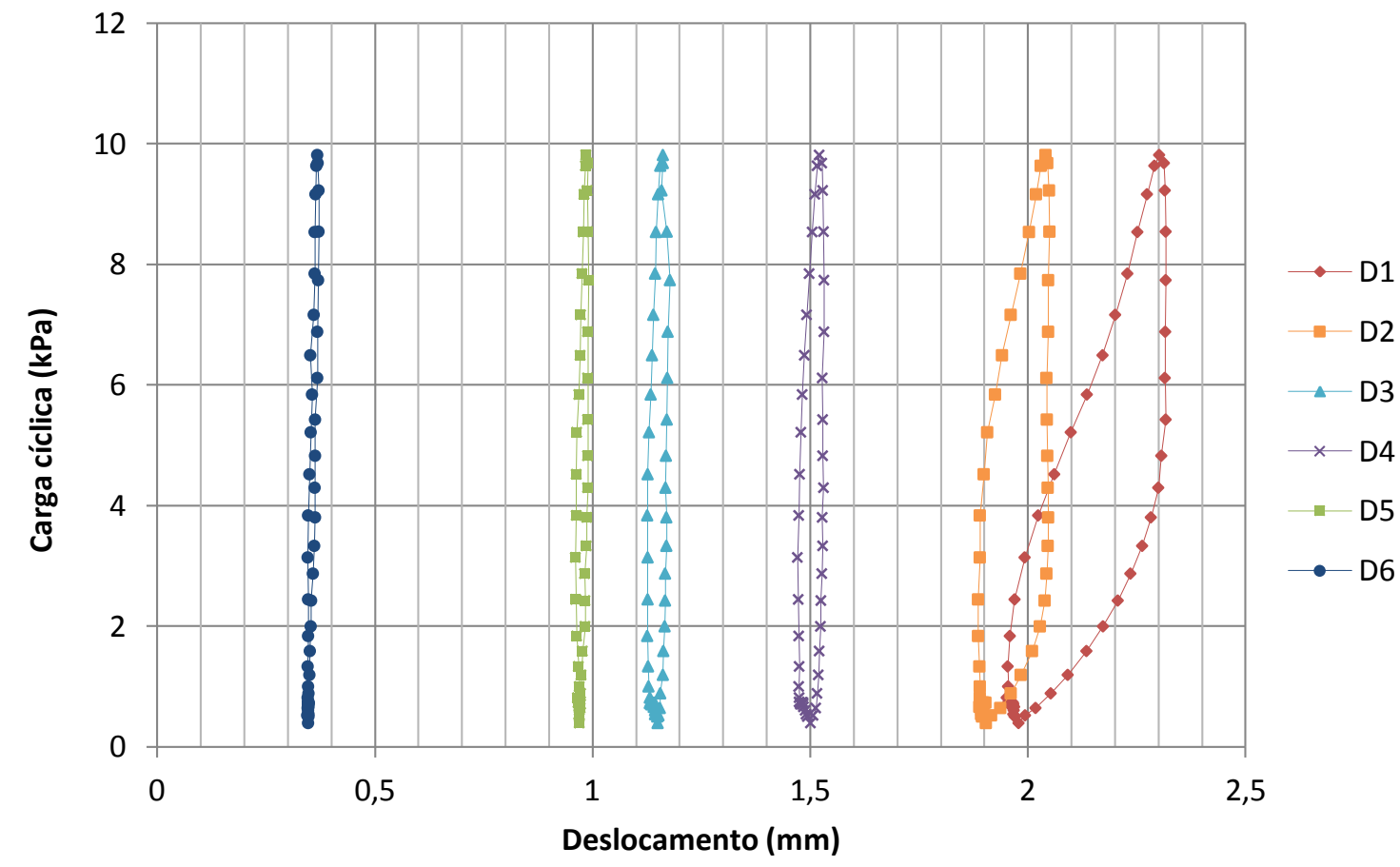

Figura 4.19 - Deslocamento registrado nos medidores D1 a D6 no último ciclo da tensão de 40 kPa e $40 \%$ da $F_{\text {máx }}$ em silte.

Os sensores D3 e D4 que idealmente deveriam fornecer deslocamentos iguais pois eles ficam posicionados paralelos e na mesma distância da garra, como esquema da Figura 3.27, não apresentaram os mesmos deslocamentos. 
De acordo com procedimento adotado pela literatura os resultados foram representados por uma curva média de deslocamentos do corpo de prova. A Figura 4.20 mostra a média dos deslocamentos dos sensores D1 ao D6, correspondentes a 300 ciclos com carga de $40 \%$ da $F_{\text {máx }}$ e tensão confinante de $40 \mathrm{kPa}$.

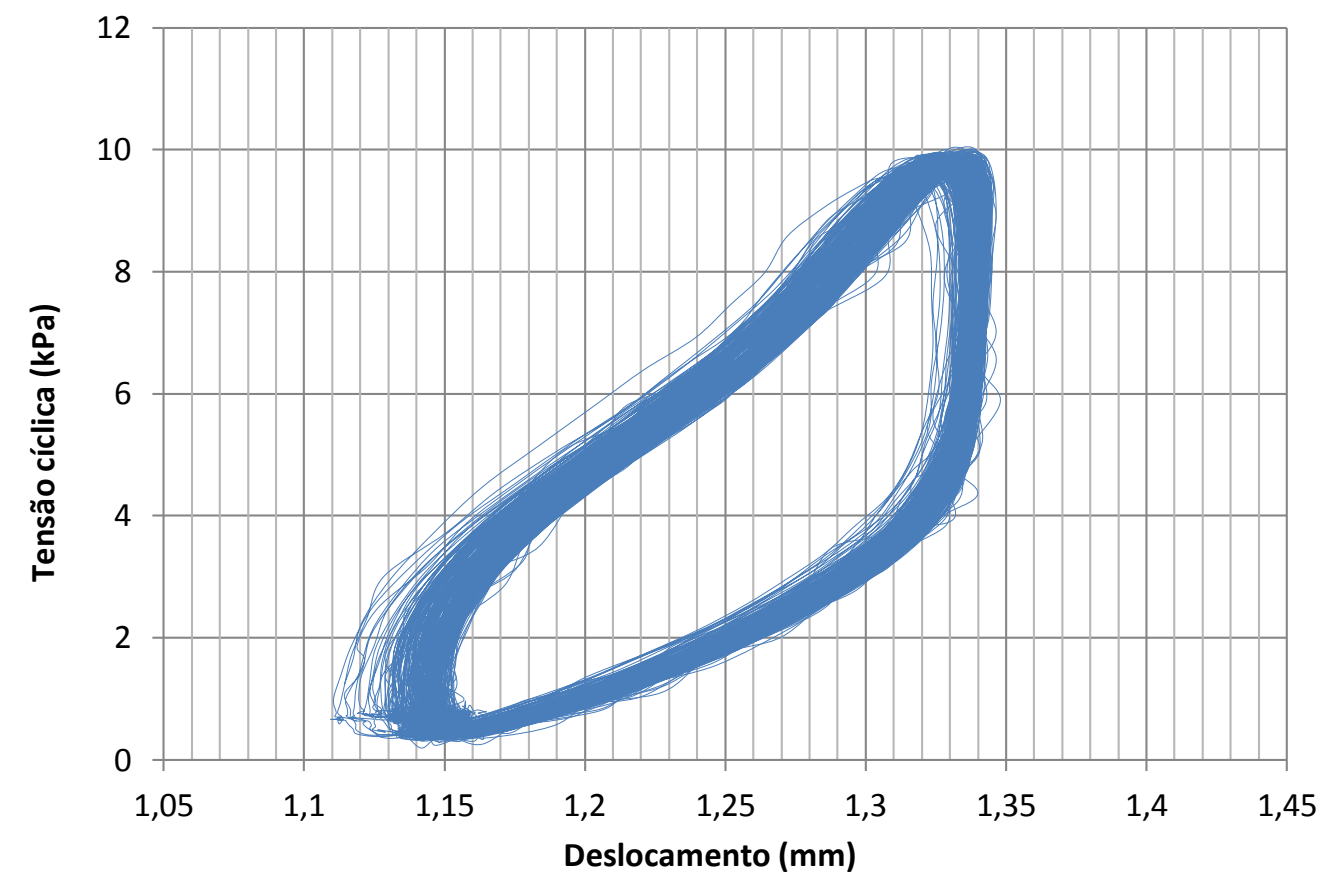

Figura 4.20 - Ciclagem completa a $40 \%$ da $F_{\text {máx }}$ e tensão, $\sigma$, de $40 \mathrm{kPa}$ em silte.

O gráfico mostra que no início da ciclagem ocorrem os maiores deslocamentos, que com a continuidade da ciclagem ainda crescem, porém, a uma taxa de crescimento inferior ao inicial e tendem a diminuir e estabilizar o incremento de deslocamentos.

Para cada nível de carregamento (Nível 20, 40, 60 e $80 \%$ da $F_{\text {máx }}$ ) são acumulados deslocamentos diferentes, assim como comportamentos médios de tensão-deslocamento em cada ciclo. Os últimos ciclos dos níveis $1,2,3$ e 4 com tensão confinante de $40 \mathrm{kPa}$ estão ilustrados na Figura 4.21 a seguir. 
A ciclagem no nível de $20 \%$ da $F_{\text {máx }}$ gera amplitude de deslocamento da ordem de $0,10 \mathrm{~mm}$, a de nível de $40 \%$ da $F_{\text {máx }}$ resulta em amplitude de cerca de 0,20 $\mathrm{mm}$, para o nível de $60 \%$ da $F_{\text {máx }}$ a amplitude aumenta para $0,40 \mathrm{~mm}$, e para o nível de $80 \%$ da $F_{\text {máx }}$ a amplitude aumenta expressivamente, ficando em torno de 1,20 $\mathrm{mm}$.

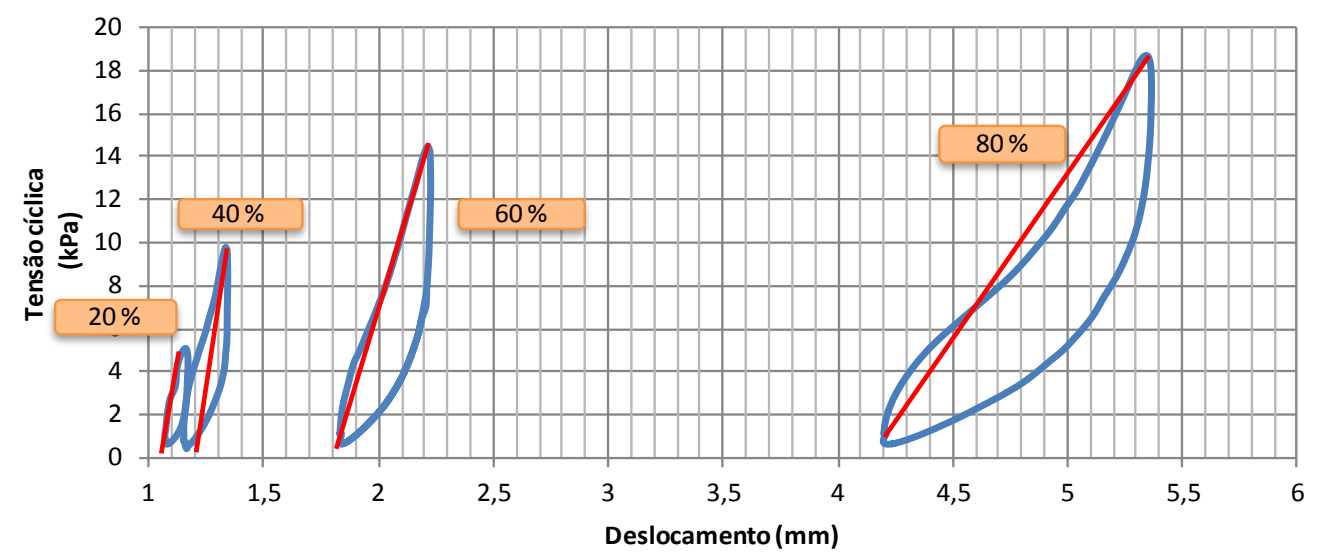

(a)

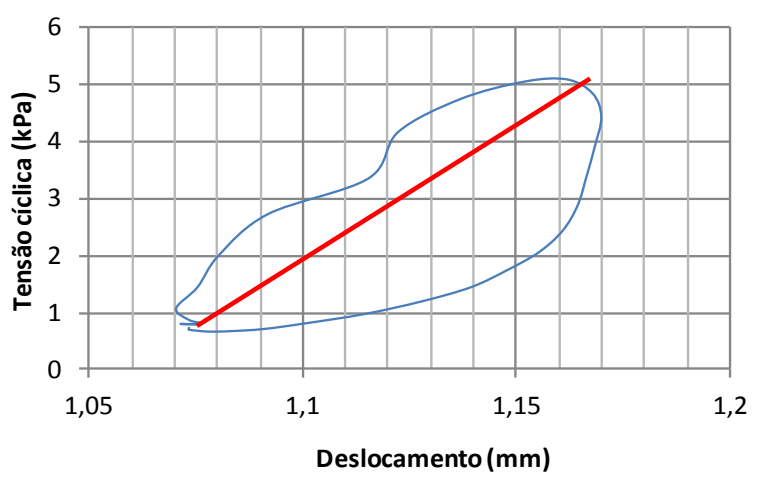

(b)

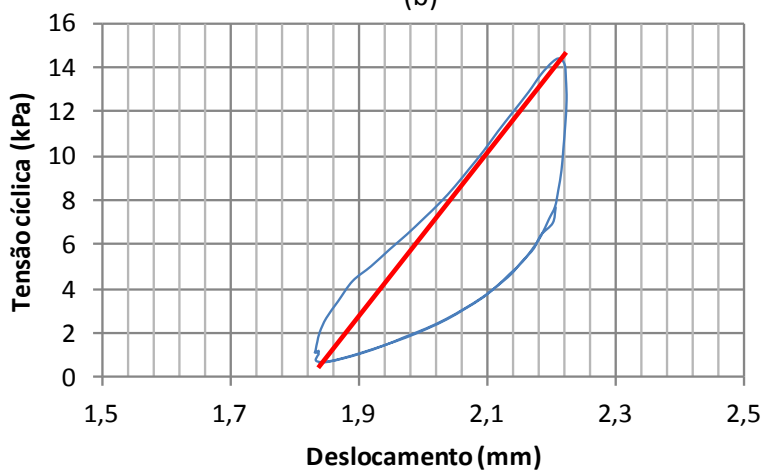

(d)

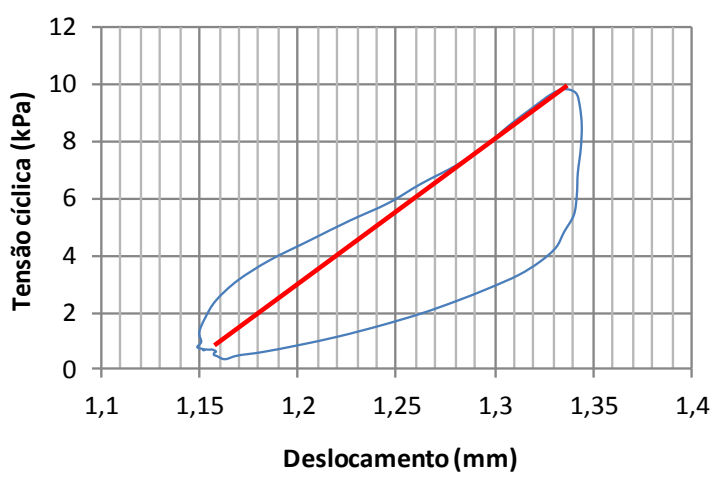

(c)

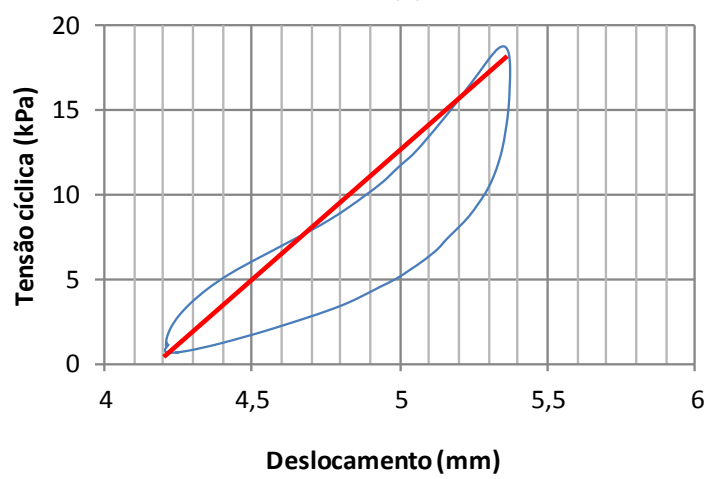

(e)

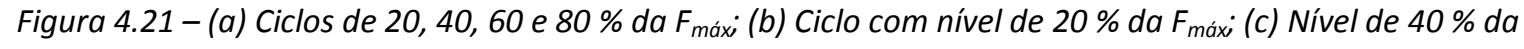
$F_{\text {máxi }}(d)$ Nível de $60 \%$ da $F_{\text {máxi }}(e)$ Nível de $80 \%$ da $F_{\text {máx }}$ e projeção do módulo de resiliência (reta) para tensão de $40 \mathrm{kPa}$ em silte. 
O cisalhamento do reforço no silte gera deformações no corpo de prova como se pode visualizar na Figura 4.22 a seguir.

A solicitação do reforço produz diferentes resultados ao longo do corpo de prova, onde certas vezes o elemento longitudinal se desprende dos elementos transversais (elementos de arraste), e em outras o elemento transversal é arrastado juntamente com o longitudinal conforme o reforço é solicitado e sofre deformações.

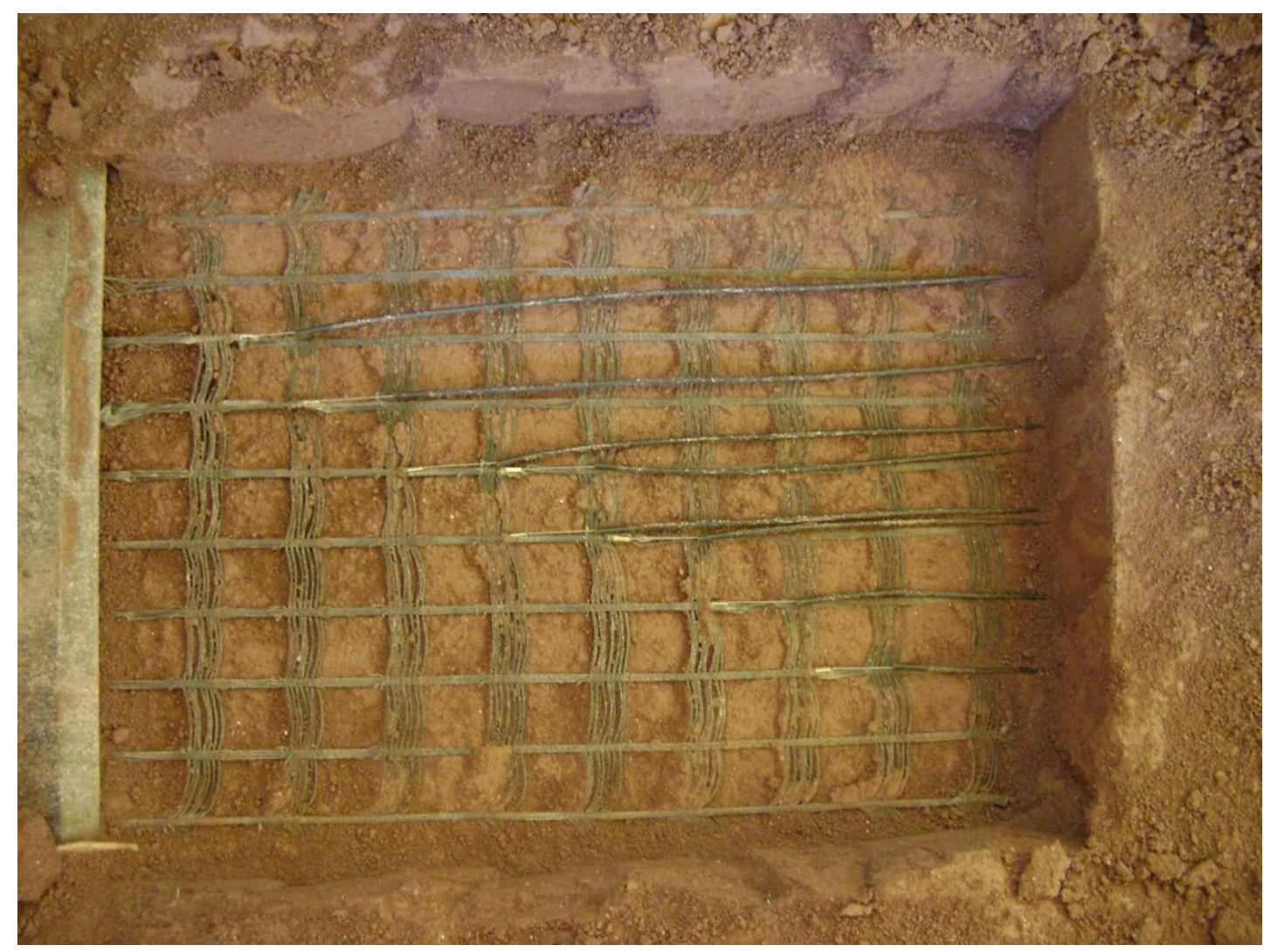

Figura 4.22 - Reforço cisalhado no silte (Ensaio CC1).

Durante os ensaios no silte, era comum a ocorrência de os primeiros elementos transversais próximos à frente da caixa de ensaios se deslocarem junto com o elemento longitudinal, gerando um deslocamento relativamente pequeno, já na parte central e traseira da amostra era comum os elementos transversais se soltarem gradativamente, passando a deslocar apenas o elemento longitudinal. 
Por fim, a partir das diferentes informações apresentadas, pode-se calcular o módulo de resiliência de cisalhamento de interface, a relação entre a taxa de carga e deslocamento, calculada de acordo com a Equação 2.14 anterior. A Figura 4.23 mostra a variação do módulo cisalhante com o nível de Tensão aplicado no ensaio em Silte.

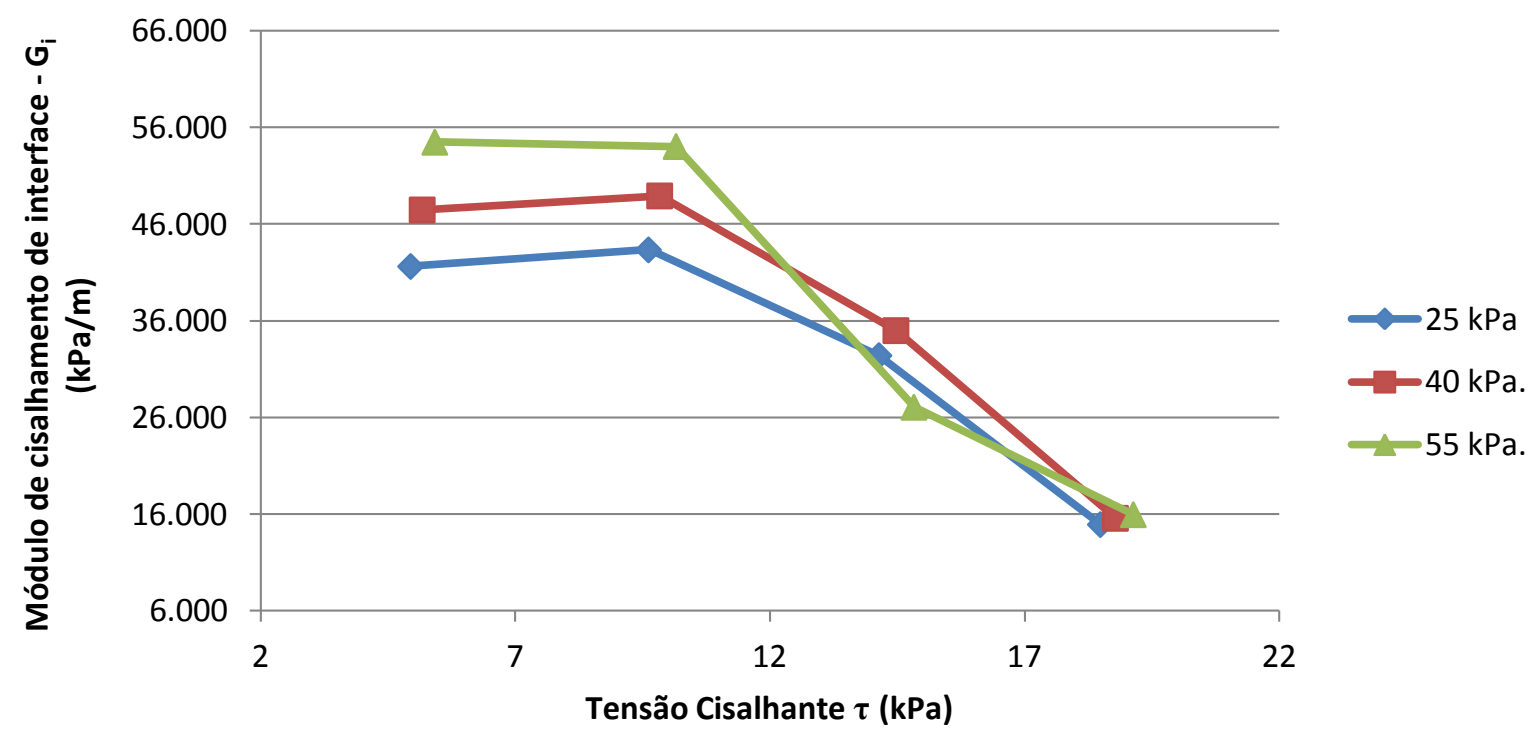

Figura 4.23 - Modulo de resiliência $\left(G_{i}\right)$ de interface versus tensão cisalhante $(\tau)$ em silte.

O comportamento exibido no gráfico se mostra semelhante ao obtido na areia, e também apresenta valores de módulo de resiliência inferiores aos descritos na literatura, que utiliza materiais mais rígidos, provenientes de outros polímeros e tensões cisalhantes menores. Como nesta pesquisa o reforço utilizado apresenta maior deformabilidade e maior comprimento do corpo de prova, o módulo resiliente medido corresponde, provavelmente a um nível de deslocamento elevado, e baseado no comportamento de solos, o módulo de elasticidade diminui para níveis de deformações maiores. Acredita-se que esta pode ser a principal razão para a diferença observada com relação aos ensaios de Perkins (2004) e Holley (2009) que utilizaram corpos de prova com aproximadamente $80 \mathrm{~mm}$ de comprimento e geogrelhas de Polipropileno que apresentam deformabilidade inferior à utilizada nesta 
pesquisa, resultando em valores de módulo de resiliência cerca de duas vezes os obtidos nestes ensaios.

\section{$4.3 \quad$ Brita}

\subsubsection{Arrancamento Brita}

Os ensaios de arrancamento deste grupo de ensaios geraram as curvas força versus deslocamento expostas a seguir (Figura 4.24), com variações apenas das tensões confinantes em 25,40 e $55 \mathrm{kPa}$.

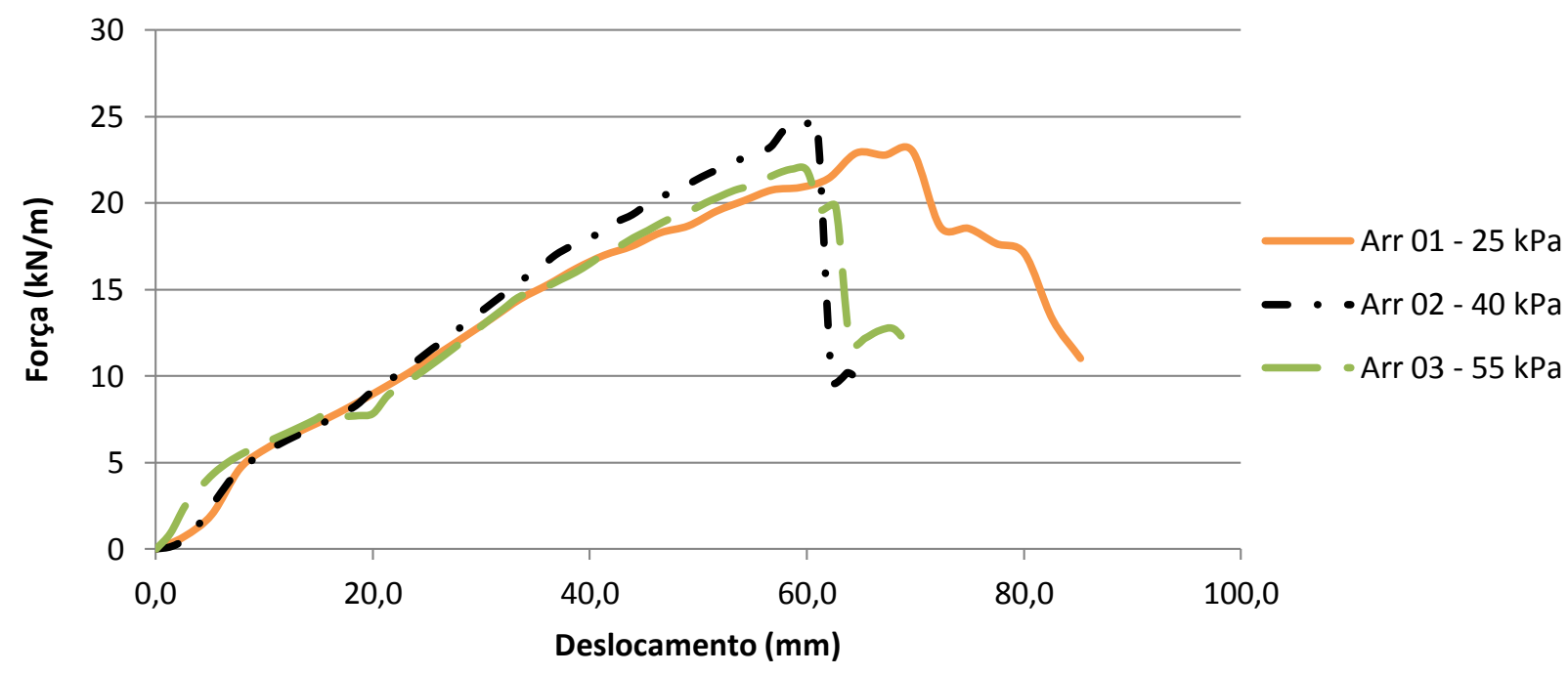

Figura 4.24 - Curvas força de arrancamento versus deslocamento da garra em brita.

Os ensaios mostraram que mesmo com o aumento da tensão confinante até os níveis ensaiados não houve aumento na resistência máxima ao arrancamento e nem mudanças significativas de deslocamentos. Isto contradiz o conhecimento que se tem sobre materiais granulares, onde a resistência é proporcional às tensões confinantes. Assim, não foi possível definir uma envoltória de resistência correspondente ao arrancamento. Para os ensaios de 
ciclagem, trabalhou-se então, com porcentagens de 20, 40 e $60 \%$ da média das forças máximas de arrancamento registradas (Figura 4.24).

Nos ensaios de arrancamento com a brita era comum ao final dos ensaios ocorrerem rupturas pontuais em alguns elementos longitudinais devido à abrasão com os grãos de brita, porém, as resistências ao arrancamento foram consideradas devido ao comportamento dos deslocamentos ao longo do reforço, que tendem à estabilização, subentendendo-se que a carga de ruptura estava próxima ou já havia sido alcançada, e as rupturas ocorriam após o arrancamento com o excesso de deslocamentos do reforço.

Os deslocamentos ao longo da geogrelha encontram-se na Figura 4.25 e podem ser considerados típicos em relação aos demais ensaios realizados.

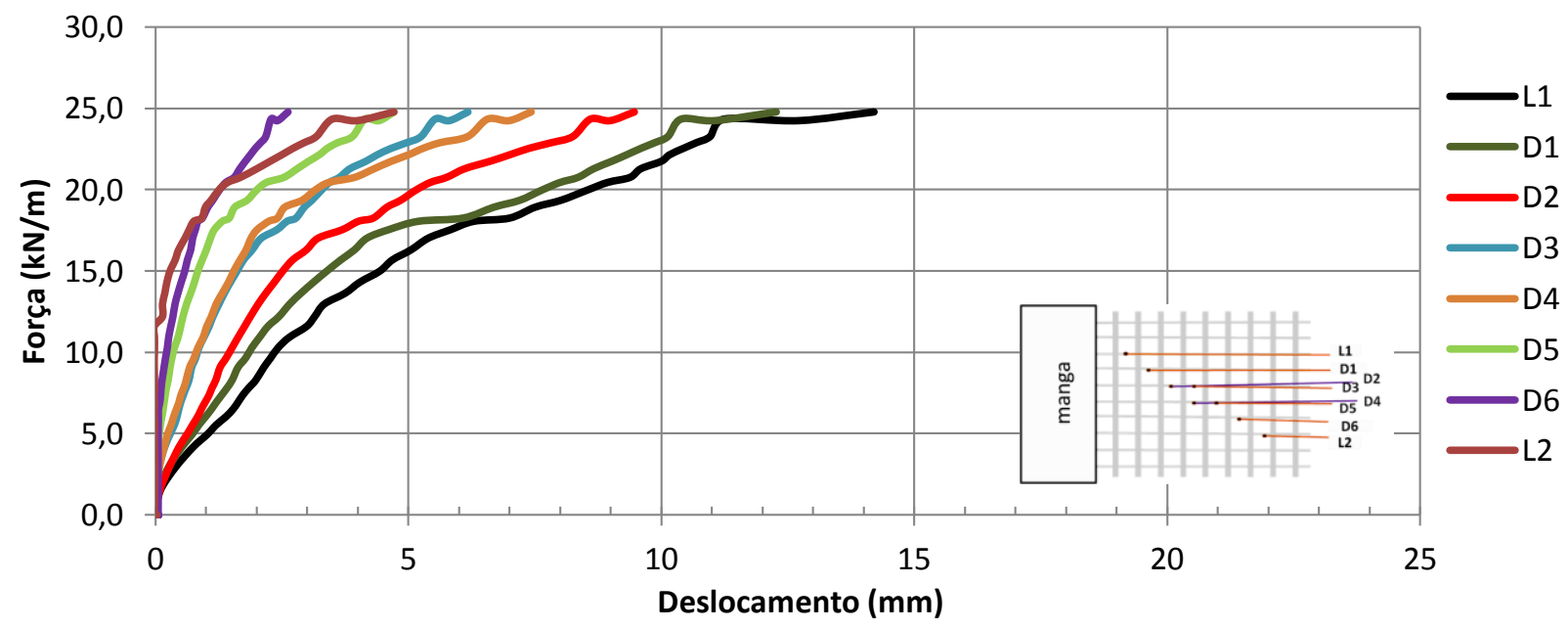

Figura 4.25 - Deslocamento dos sensores ao longo da amostra durante arrancamento com tensão, $\sigma$, de 40 kPa em brita (Ensaio AB2).

O comportamento dos deslocamentos neste material se mostrou em parte semelhante ao da areia, onde o material se desloca gradualmente ao longo de seu comprimento, aparentando estar em um solo menos rígido que permite movimentação e solicitação do 
reforço integralmente a uma força de arrancamento relativamente menor, porém, as magnitudes de forças máximas de arrancamento são semelhantes às do silte.

No restante dos ensaios de arrancamento foram obtidas pequenas variações na ordem de solicitação dos elementos (L1, D1, D2...) com o andamento do ensaio, provavelmente devido à variabilidade do tamanho das partículas (solo bem graduado). Pôde-se perceber que o reforço se desloca gradativamente, iniciando na parte frontal e com valores menores na parte traseira. Os sensores D3 e D4 se deslocam por grande parte do ensaio com deslocamentos semelhantes, indicando que o reforço se deslocou transversalmente por igual.

Os deslocamentos ou solicitações em função da distância da aplicação da força de arrancamento, para cada etapa do ensaio, estão representadas na Figura 4.26 a seguir.

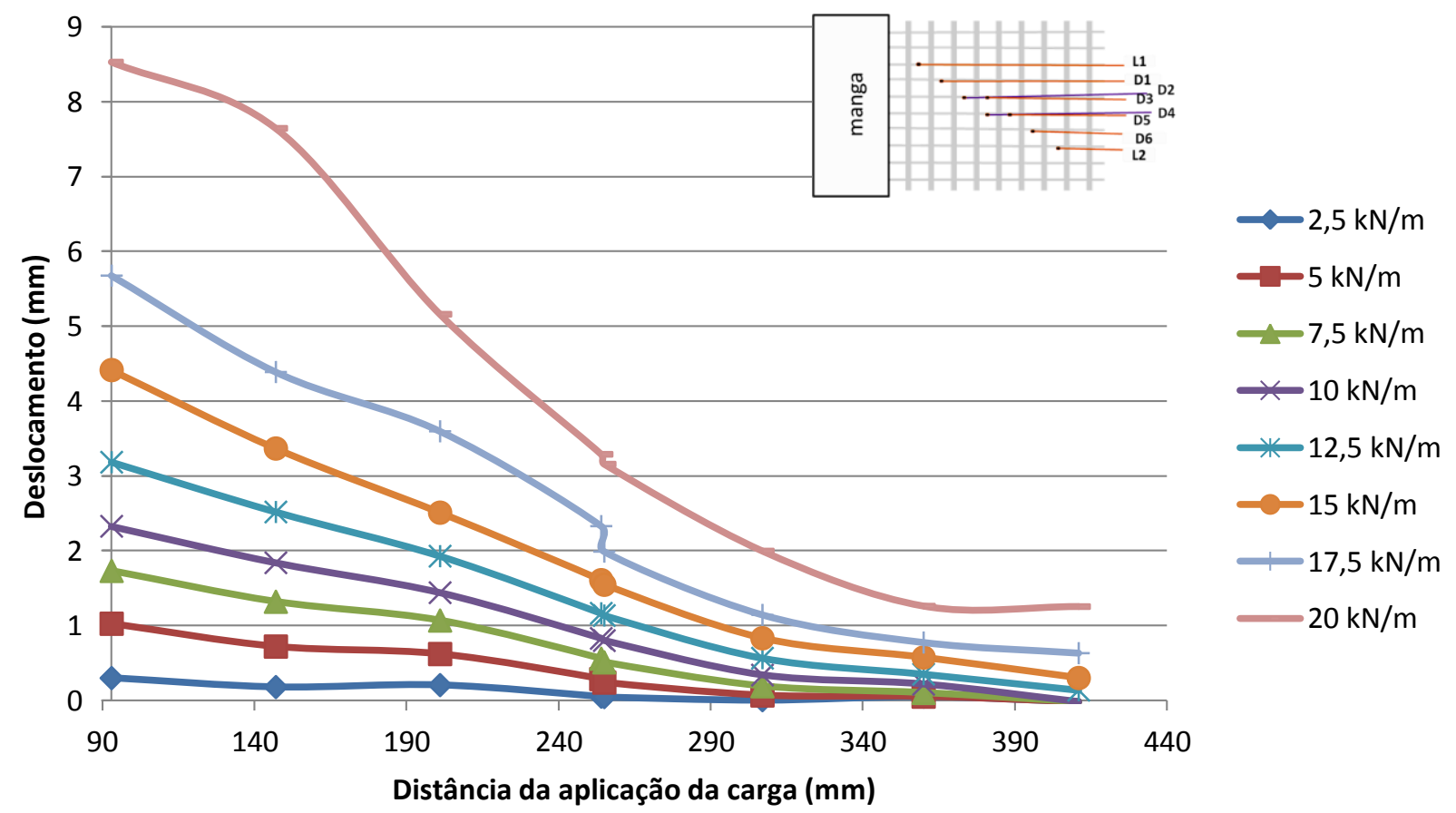

Figura 4.26 - Solicitações ao longo do corpo de prova em ensaio de arrancamento com tensão, $\sigma$, de $40 \mathrm{kPa}$ em brita (Ensaio AB2). 
No gráfico anterior nota-se que com força de $2,5 \mathrm{kN} / \mathrm{m}$ ocorre solicitação de cerca de $260 \mathrm{~mm}$ de comprimento da geogrelha, com força de $5 \mathrm{kN} / \mathrm{m}$ a solicitação aumenta para cerca de $310 \mathrm{~mm}$. Com força de $10 \mathrm{kN} / \mathrm{m}$, mobiliza-se mais de $400 \mathrm{~mm}$ da geogrelha e a partir desta força, o reforço é integralmente solicitado e o deslocamento apresenta aumento gradativo e proporcionalmente maior na parte da frente do corpo de prova, mantendo deslocamentos menores na parte traseira do corpo de prova até o ponto de carga máxima ao arrancamento $\left(F_{\text {máx }}\right)$. Notou-se ainda que na brita, o reforço solicita maior comprimento com cargas relativamente baixas, frente aos outros materiais ensaiados.

Durante os ensaios de arrancamento eram medidas as tensões normais no entorno do reforço, e foi obtido o comportamento médio representado através do gráfico da Figura 4.27 a seguir.

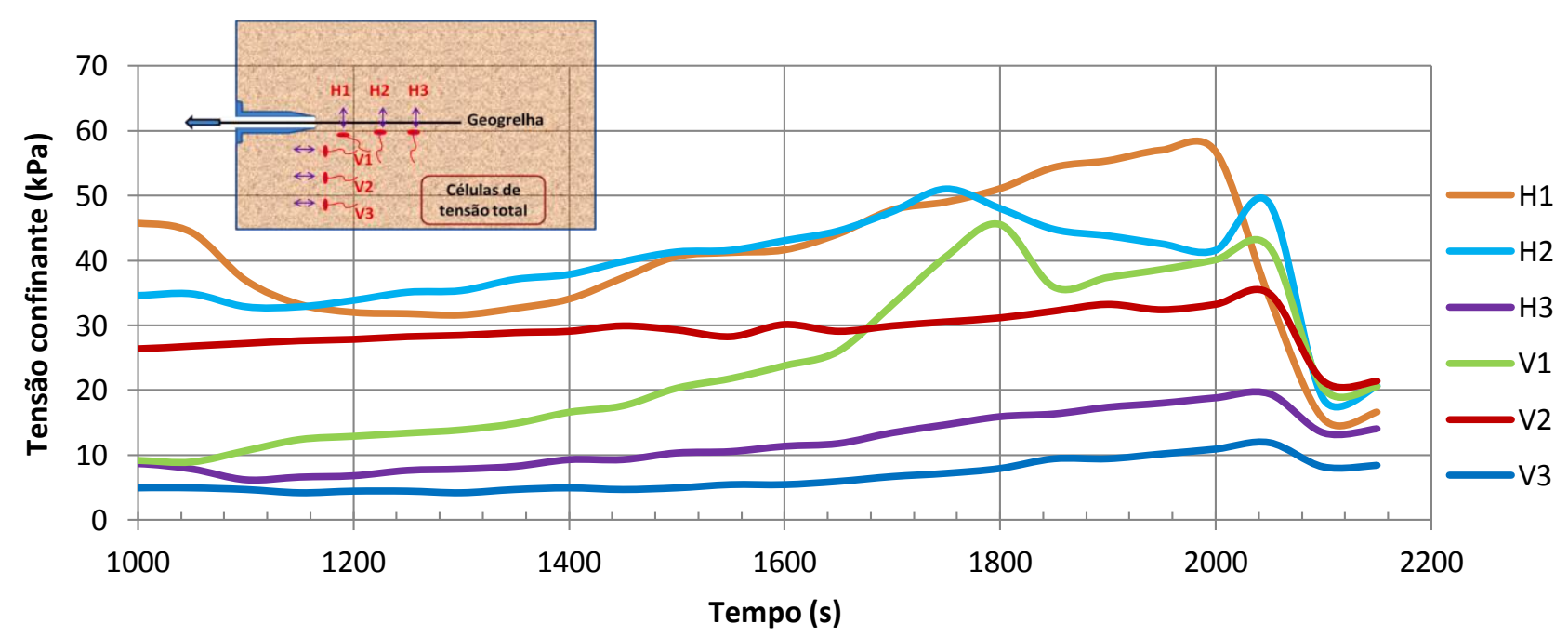

Figura 4.27 - Arrancamento com tensão, $\sigma$, de 40 kPa em brita (Ensaio AB2).

Nas regiões próximas à manga foram registradas tensões iniciais maiores do que em locais mais distantes, induzindo a ideia de que a manga influencia nas tensões que chegam efetivamente ao solo de maneira diferente neste solo. 
Nestes ensaios as tensões confinantes iniciais registradas nos mesmos pontos não apresentaram um padrão, provavelmente devido ao desconfinamento dos locais de instalação das células por escavação e posterior compactação. Conforme era iniciado o arrancamento, as tensões aumentavam proporcionalmente nos mesmos pontos da caixa em todos os ensaios de arrancamento, independente da variação das tensões iniciais, aumentando inicialmente na frente e gradualmente até a traseira. Os sensores posicionados de forma horizontal $(\mathrm{H}$, leituras de tensão vertical) apresentam grande queda de tensão no início do ensaio, sendo mais acentuada na célula H1. Após a queda de tensões no entorno da amostra ocorre o aumento gradativo das tensões principalmente próximo à face, até o arrancamento do corpo de prova.

Para os sensores posicionados na direção vertical (V, leituras de tensão horizontal), verifica-se que o sensor V1 sofre grande alteração com o início do ensaio, e conforme o corpo de prova é tracionado é registrado aumento de $35 \mathrm{kPa}$. A célula V2 apresenta aumento menos pronunciado de $10 \mathrm{kPa}$ e a célula $\mathrm{V} 3$ mostra pequeno e constante aumento de tensões, mostrando que a variação de tensões a cerca de $150 \mathrm{~mm}$ da distância vertical do reforço é proporcionalmente pequena, e que as dimensões da caixa de ensaios são suficientes para não interferir no comportamento do ensaio.

\subsubsection{Ciclagem Brita}

Para estabelecer os níveis de carga de ciclagem foi considerada uma carga média dos ensaios de arrancamento, utilizando-se forças correspondentes a 20, 40 e $60 \%$ da força máxima de arrancamento $\left(F_{\text {máx }}\right)$. Para a brita foram utilizados três níveis de força de arrancamento, pois devido ao alto nível de agressividade deste solo granular com o reforço, não seria possível a aplicação de muitas séries e mesmo de séries com muitos ciclos. 
No primeiro ensaio de ciclagem, o corpo de prova rompeu ainda no nível de condicionamento, devido à abrasão dos filamentos com os grãos maiores do solo granular. Devido ao desgaste rápido da amostra e visando representar a maior quantidade possível de níveis e estágios de ciclagens os níveis foram reduzidos em $80 \%$ para o condicionamento e $66 \%$ para os níveis 1,2 e 3, aplicando apenas 200 ciclos de condicionamento e 100 ciclos para cada nível de força e confinante. O nível de condicionamento foi realizado com uma carga cíclica e tensão confinante média em relação à programação de carregamentos aplicados, que para a brita foi de $40 \%$ da $F_{\text {máx }}$ e tensão confinante de $40 \mathrm{kPa}$.

Após a ciclagem de condicionamento os níveis de ciclagem eram iniciados pelo carregamento de menor intensidade $(20 \%)$ buscando-se manter a integridade do corpo do sistema solo-reforço. De acordo com as envoltórias citadas anteriormente o ensaio era iniciado com nível de $20 \%$ e tensão confinante de $25 \mathrm{kPa}$. Nos estágio seguintes, mantida constante a força de $20 \%$ de arrancamento, as tensões confinantes $(\sigma)$ eram aumentadas para 40 e $55 \mathrm{kPa}$, seguindo-se pelos níveis de 40 , e $60 \%$ da $F_{\text {máx }}$ com seus respectivos aumentos de tensões confinantes. Era realizado o aumento das tensões confinantes, porém, as tensões de ciclagem eram mantidas em um mesmo nível, representados no gráfico a seguir juntamente com os deslocamentos registrados nos transdutores de deslocamentos D2 e D5 posicionados próximo à aplicação de força (à frente) e mais ancorados (atrás), respectivamente, buscando representar o comportamento em termos de deslocamentos em diferentes pontos do corpo de prova.

A Figura 4.28 a seguir mostra o deslocamento médio do reforço em cada nível de solicitação, considerando os sensores D2 e D5 que se encontram em posições equidistantes da frente e da traseira do corpo de prova, respectivamente. 


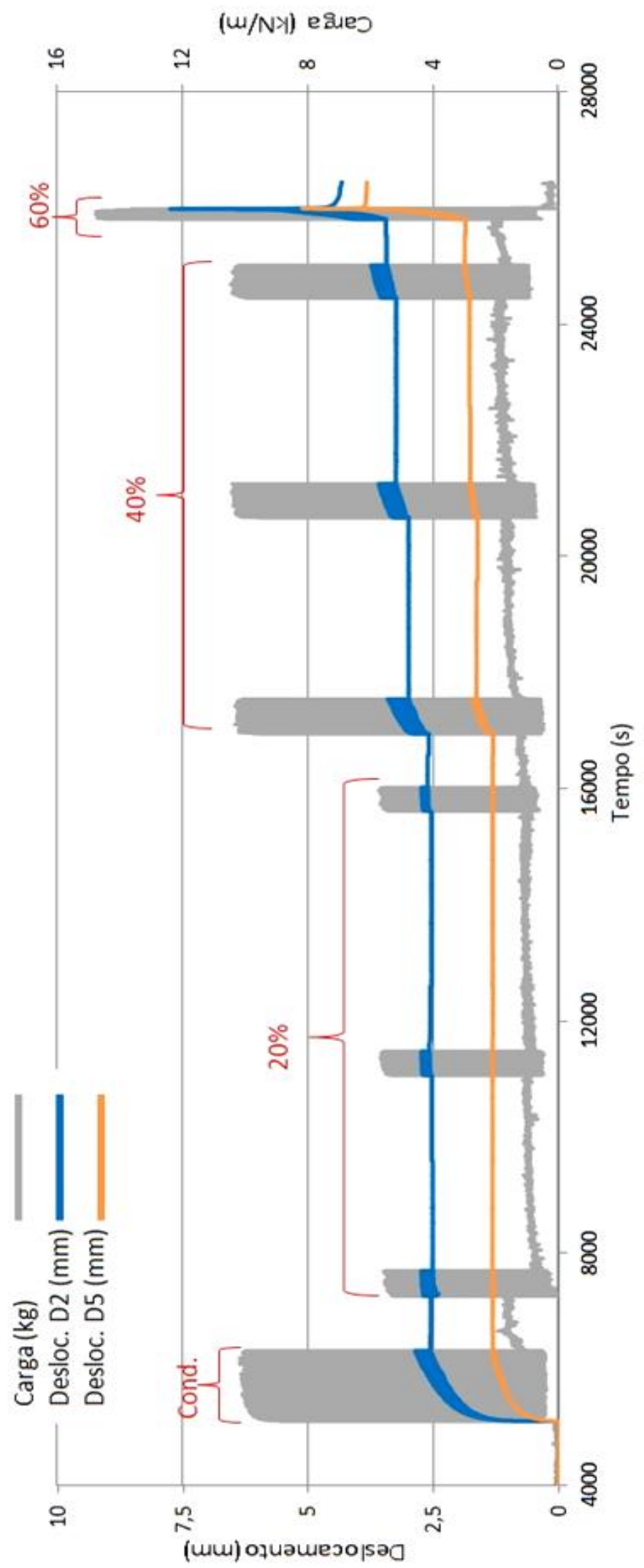

Figura 4.28 - Níveis de carregamento e deslocamento da amostra em brita. 
Assim como nos outros solos ensaiados, percebe-se que no nível de condicionamento são adquiridos grande parte dos deslocamentos registrados até o final do nível $2(40 \%$ da $\left.F_{\text {máx }}\right)$. No nível 1 de carregamentos $\left(20 \%\right.$ da $\left.F_{\text {máx }}\right)$ os deslocamentos se mantém durante os 3 estágios de confinantes. No nível 2 de carregamentos (40\% da $F_{\text {máx }}$ ) nota-se tendência em aumento gradativo dos deslocamentos. No nível $3\left(60 \%\right.$ da $F_{\text {máx }}$ ) ocorre de maneira bem pronunciada a tendência ao aumento dos deslocamentos que levaram à ruptura do material logo no início do primeiro estágio do nível de $60 \%$.

Observando-se em detalhe o nível de $40 \%$ da $F_{\text {máx }}$ com tensão confinante de $40 \mathrm{kPa}$ da Figura 4.28 anterior, apresentado na Figura 4.29 a seguir tem-se o comportamento de tensão cisalhante, deslocamento e tensão no solo versus tempo de ensaio decorrido.

Os comportamentos relativos à tensão de ciclagem, deslocamento da amostra e tensão total no solo mostrados na Figura 4.29 a seguir foram considerados padrões nos ensaios realizados com brita.

O gráfico mostra nível de carregamento aplicado estável e controlado dentro dos limites especificados do ensaio. Juntamente com a aplicação da carga os transdutores de deslocamento registram deslocamentos de maiores magnitudes nas partes mais à frente da amostra (L1, D1 e D2) e magnitudes menores de deslocamentos na parte traseira da amostra (L2, D6 e D5), significando que o ancoramento da amostra induz a deformações na mesma.

Assim como nos outros solos, os tratamentos de deslocamentos cíclicos foram baseados nos sensores D1 a D6, pois os sensores L1 e principalmente L2 apresentam certo ruído elétrico, além de imprecisão e menor confiabilidade. 

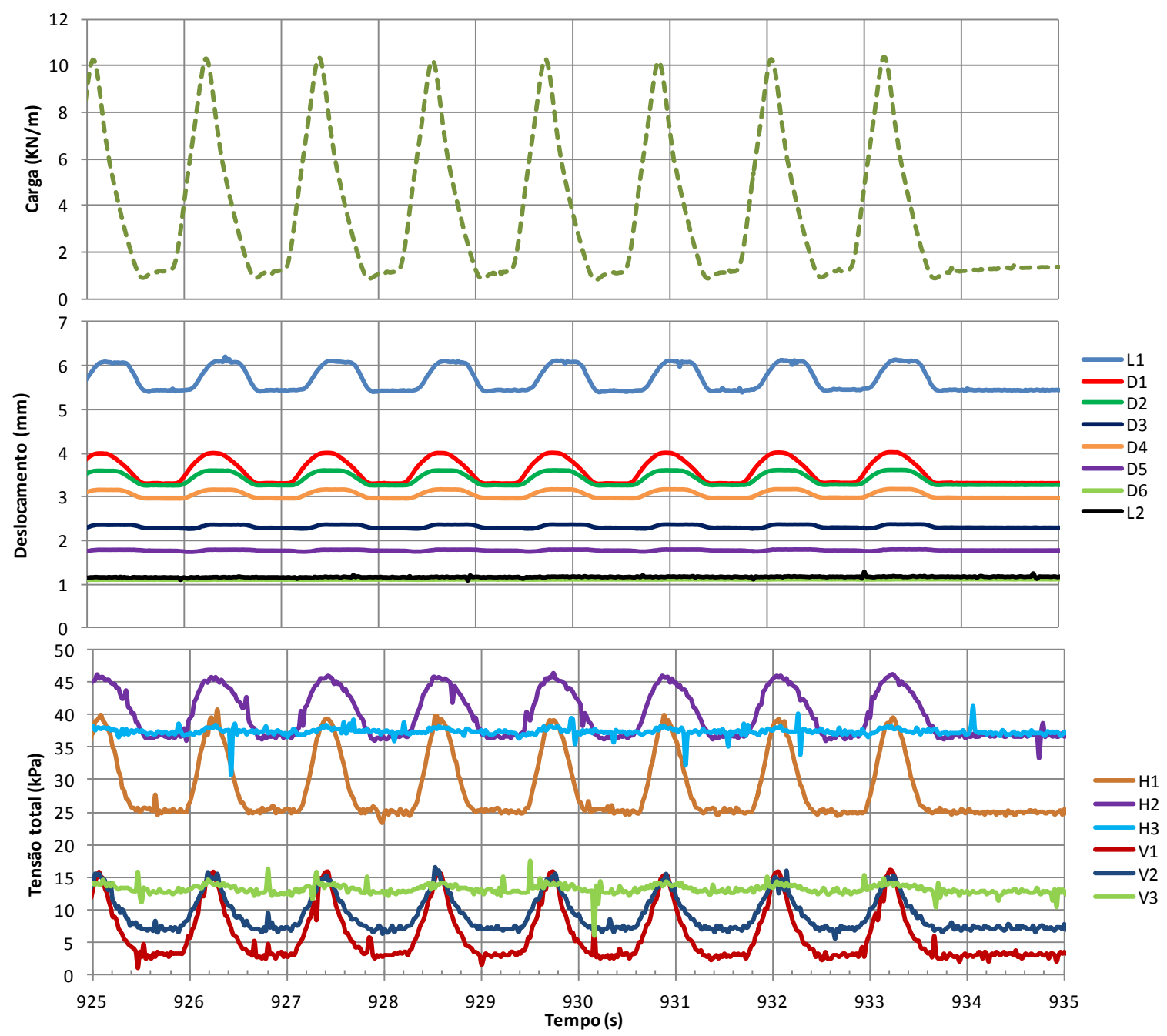

Figura 4.29 - Carga de ciclagem, deslocamento pontual e tensão total versus tempo de ensaio, com $40 \%$ da $F_{\text {máx }}$ e tensão, $\sigma$, de $40 \mathrm{kPa}$ brita.

A variação de tensões com a ciclagem ocorre de maneira semelhante à registrada nos ensaios de arrancamento, onde a célula H1 apresenta grande amplitude de variação de tensões, ficando em cerca de $15 \mathrm{kPa}$, seguida por menor amplitude na célula $\mathrm{H} 2$, apresentando cerca de $10 \mathrm{kPa}$ de variação e a célula H3 apresenta variação de tensões mínima, em cerca de $2 \mathrm{kPa}$. A análise das tensões nestas células mostra que o reforço é mais solicitado até cerca de metade de seu comprimento ancorado $(260 \mathrm{~mm}$ dos $510 \mathrm{~mm}$ ), devido ao bom imbricamento do material granular no reforço. 
As células V1, V2 e V3 também apresentam grande variação com o andamento do ensaio, mostrando a variação da tensão com a profundidade, no decorrer da ciclagem. São registradas variações de tensões de magnitudes diferentes nestas células, ficando em cerca de $12 \mathrm{kPa}$ na mais próxima à manga e cerca de $2 \mathrm{kPa}$ na mais distante. A célula V3 apresenta desde o início das ciclagens pequena variação em relação ao seu valor antes do início do ensaio e mesmo em relação à ciclagem sua amplitude é menor, mostrando que a altura da caixa é suficiente para a dissipação das tensões no solo, com pouca influência das paredes da caixa no ensaio.

Analisando-se individualmente um ciclo completo de carga são registrados os deslocamentos ilustrados no gráfico da Figura 4.30 a seguir, ao longo do reforço.

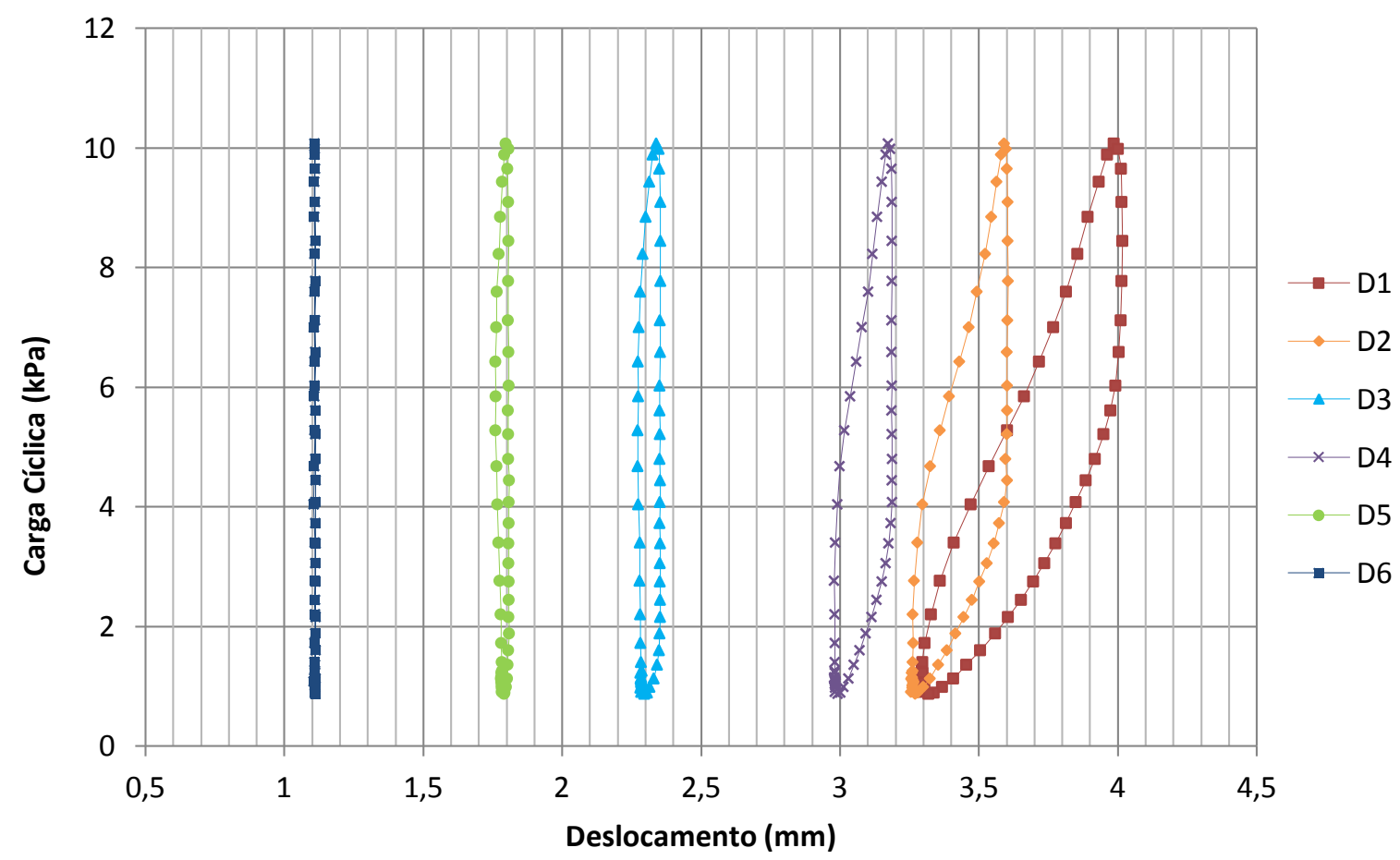

Figura 4.30 - Deslocamento registrado nos medidores D2 a D5 no último ciclo da tensão confinante de 40 kPa e $40 \%$ da $F_{\text {máx }}$ em brita.

As curvas representando os deslocamentos nos diversos pontos do corpo de prova mostram comportamentos parecidos na parte frontal do reforço (D1 e D2) e outro 
comportamento na parte traseira do reforço (D5 e D6). Os sensores intermediários mesmo estando posicionados na mesma distância do ponto de aplicação de cargas (em elementos diferentes), apresentaram comportamentos distintos onde 0 sensor D4 mostrou comportamento semelhante ao da parte frontal do reforço e o D3 semelhante à parte traseira do reforço.

Tal gráfico mostra o padrão de deslocamentos ao longo da amostra, e por esta razão resolveu-se representá-los por uma curva média de deslocamentos do corpo de prova, que permitiram gerar a sequência de curvas representadas na Figura 4.31 a seguir. Tal sequência de curvas é composta pela média de deslocamentos registrados nos sensores D1 ao D6, ilustrando desde o ciclo 1 ao ciclo 300 referentes ao carregamento de $40 \%$ da $F_{\text {máx }}$ e tensão confinante, $\sigma$, de $40 \mathrm{kPa}$.

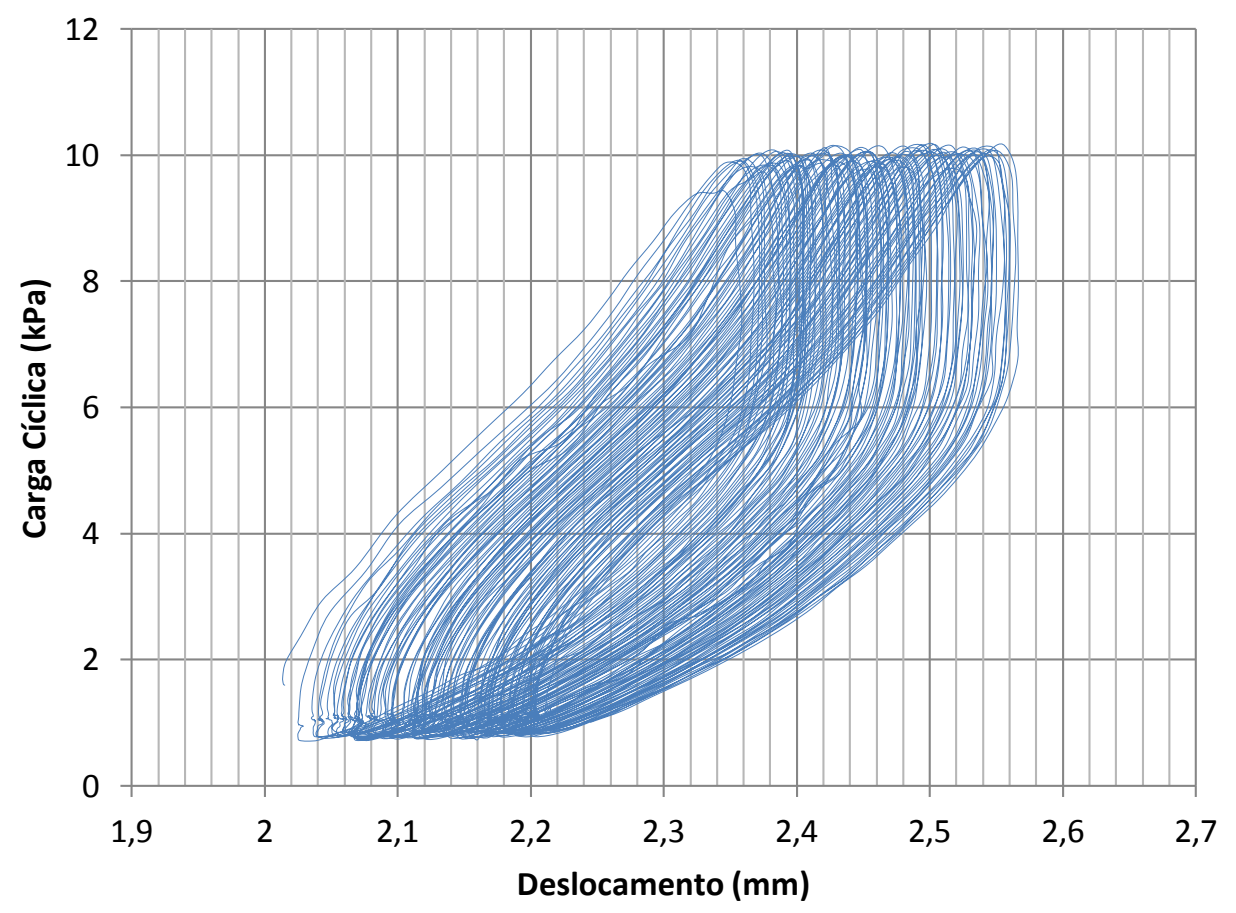

Figura 4.31 - Ciclagem completa a $40 \%$ da $F_{\text {máx }}$ e tensão, $\sigma$, de $40 \mathrm{kPa}$ em brita. 
Através do gráfico anterior nota-se que nos primeiros ciclos é ligeiramente maior o acúmulo de deslocamentos, e com a continuidade da ciclagem os deslocamentos ainda aumentam e não parecem tender a estabilizar.

Para cada nível de carregamento (Nível de 20, 40 e $60 \%$ da $F_{\text {máx }}$ ) são acumulados deslocamentos diferentes, assim como comportamentos médios de tensão-deslocamento em cada ciclo. Os últimos ciclos dos níveis 20,40 e $60 \%$ da $F_{\text {máx }}$ com tensão confinante de 40 $k P a$ estão ilustrados na Figura 4.32 a seguir.

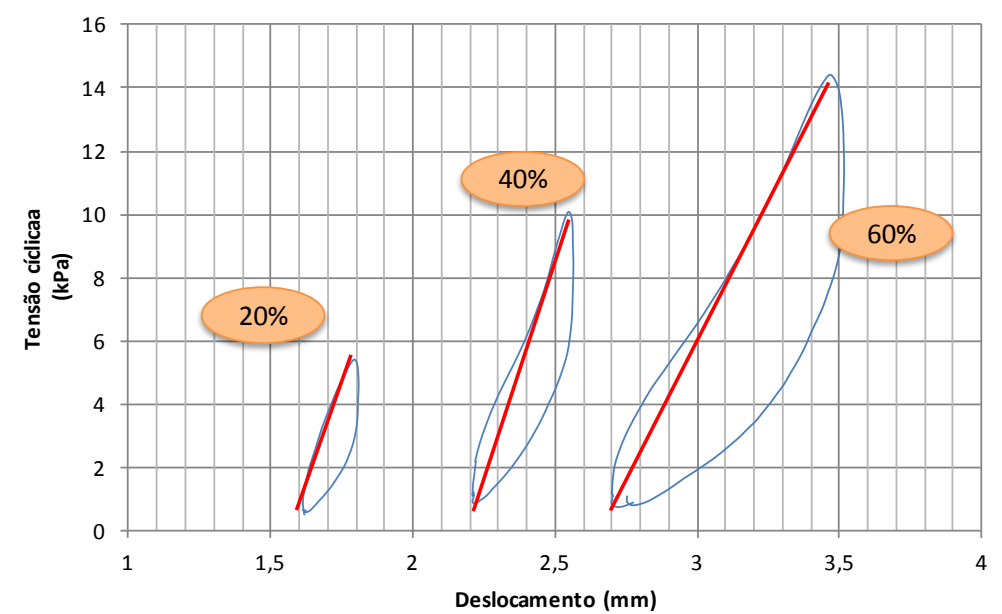

(a)

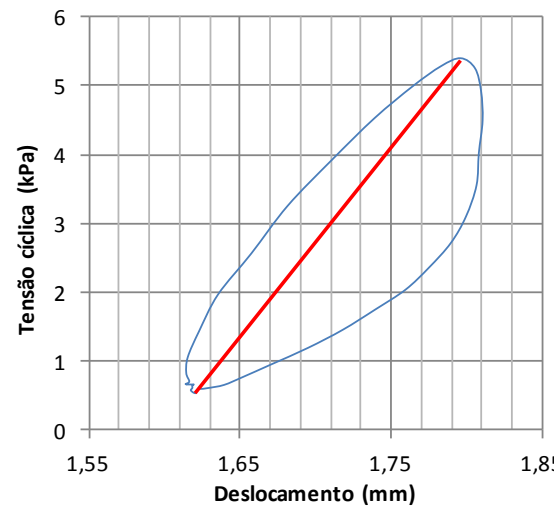

(b)

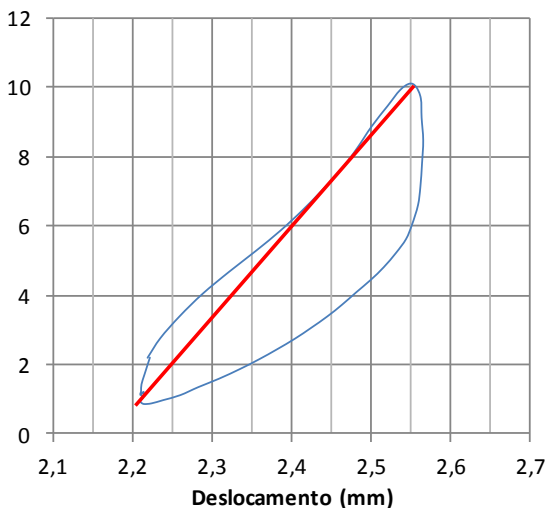

(c)

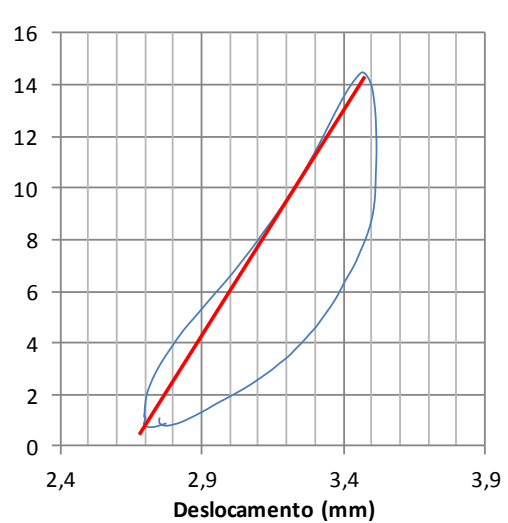

(d)

Figura 4.32 - (a) Ciclos de 20, 40 e $60 \%$ da $F_{\text {máxi }}$ (b) Ciclo nível $20 \%$ da $F_{\text {máxi }}$ (c) Nível $40 \%$ da $F_{\text {máxi }}$ (d) Nível $60 \%$ da $F_{\text {máx }}$ e módulo de resiliência (reta) para ensaios com $40 \%$ da $F_{\text {máx }}$ e tensão, $\sigma$, de 40 kPa em brita. 
A ciclagem de nível $20 \%$ da $F_{\text {máx }}$ gera amplitude de deslocamento da ordem de 0,20 $m m$, a de nível $40 \%$ da $F_{\text {máx }}$ resulta em amplitude de cerca de $0,35 \mathrm{~mm}$, para o nível $60 \%$ da $F_{\text {máx }}$ a amplitude aumenta para $0,80 \mathrm{~mm}$.

O cisalhamento do reforço na brita gera deformações no corpo de prova como se pode visualizar na da Figura 4.33 a seguir. É visível também o desgaste sofrido pela amostra na parte próxima à manga, onde a mesma sofre abrasão conforme o ensaio se realiza.

A tração da geogrelha provoca distintas reações ao longo do reforço, sendo que em certas ocasiões o elemento longitudinal se desprende dos elementos transversais (elementos de arraste), e em outras o elemento transversal é arrastado juntamente com o longitudinal conforme o reforço é solicitado e sofre deformações.

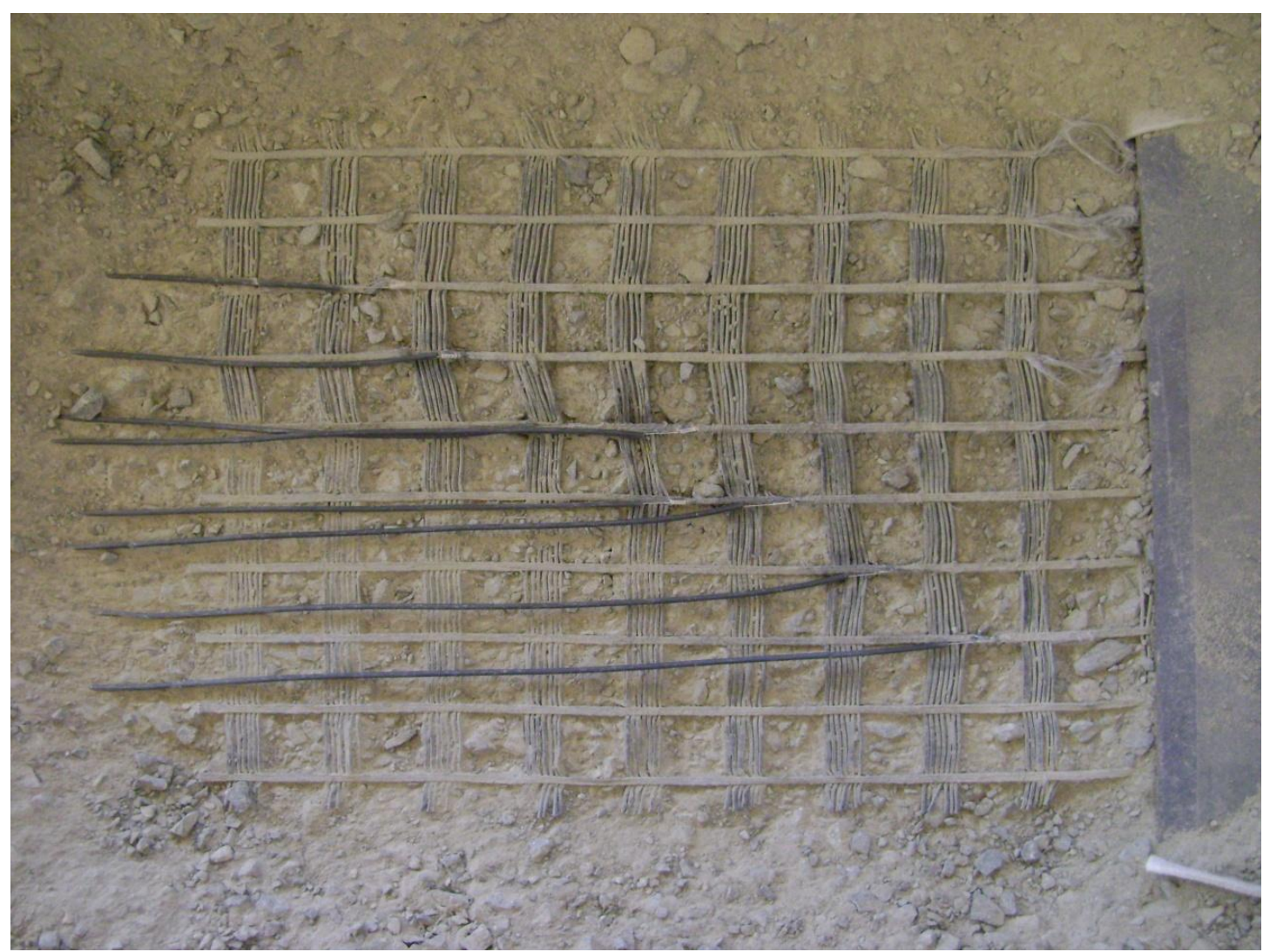

Figura 4.33 - Reforço cisalhado em brita (Ensaio CB2). 
Durante os ensaios na brita era comum apenas o primeiro e esporadicamente o segundo elementos transversais, próximos à frente da caixa de ensaios, se deslocarem junto com o elemento longitudinal. Já na parte central e traseira da amostra era comum os elementos transversais se soltarem gradativamente, passando a deslocar apenas o elemento longitudinal.

Os ensaios cíclicos com este material apresentaram a ruptura da geogrelha por abrasão proveniente do contato com as partículas maiores de brita na frente do corpo de prova (próximo ao ponto de aplicação de cargas), fato que não ocorreu nos outros tipos de solos.

Por fim, a partir das diferentes informações apresentadas, pode-se calcular o módulo de resiliência de cisalhamento de interface, a relação entre a taxa de carga e o deslocamento, calculadas de acordo com a Equação 2.14 anterior. A Figura 4.34 mostra a variação do módulo cisalhante com o nível de tensão aplicado no ensaio em brita.

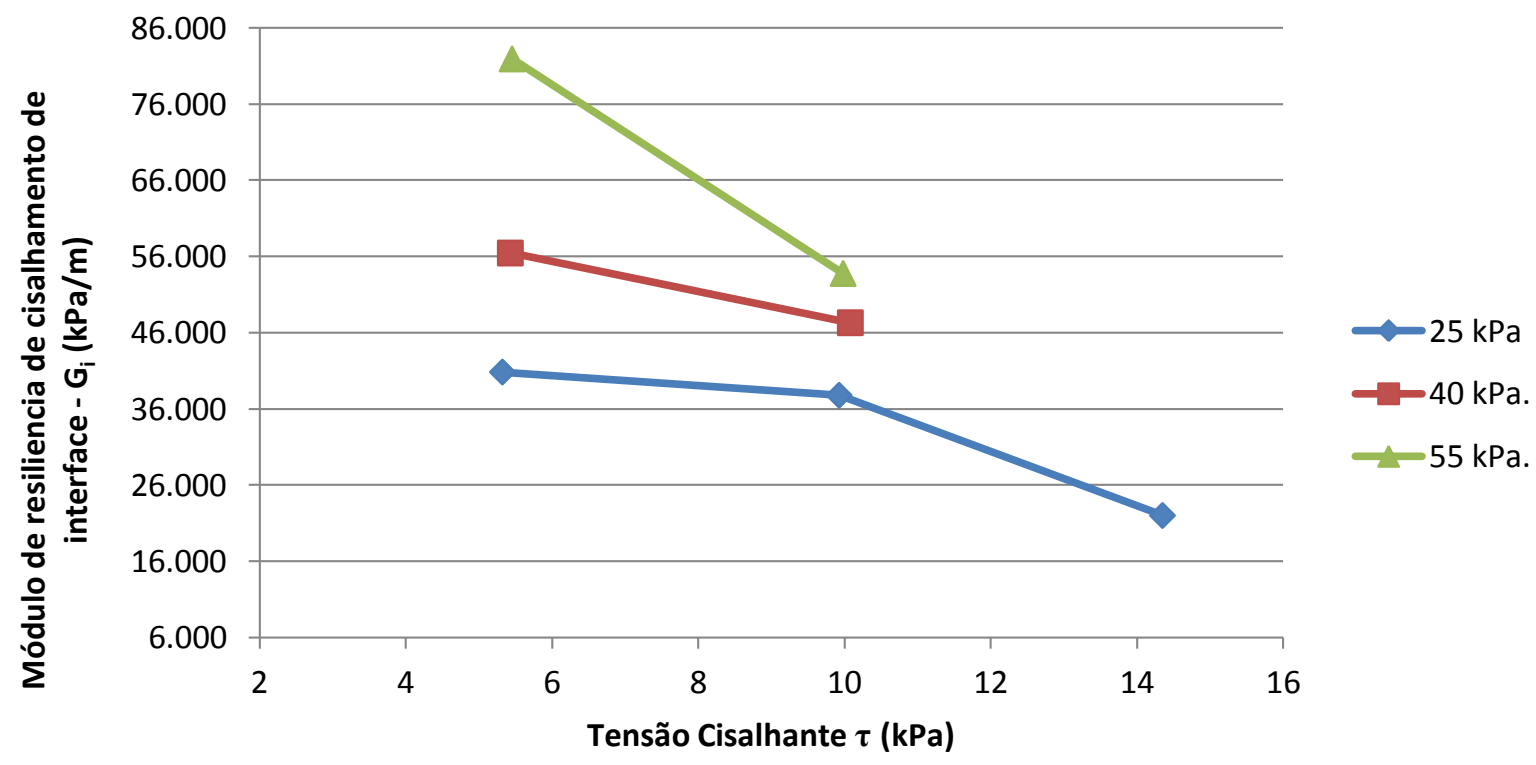

Figura 4.34 - Modulo de resiliência $\left(G_{i}\right)$ de interface versus tensão cisalhante $(\tau)$ na brita. 
A tendência do gráfico e a magnitude dos valores de módulo de resiliência obtidos nos ensaios com a brita foram semelhantes aos obtidos no silte, com valores de módulo de cerca de metade do relatado na literatura.

A brita se mostrou mais sensível à variação da tensão confinante, porém, os valores médios de $G_{i}$ ficaram abaixo dos relatados na literatura, e, assim como nos outros solos, acredita-se que a diferença nestes valores provém da maior deformabilidade do reforço utilizado e dos maiores níveis de tensão cisalhante praticados, que levavam a relativamente grandes deslocamentos ao longo do reforço, levando ainda a um comportamento distinto do solo confinante, que segundo a teoria da elasticidade dos solos, apresenta menores módulos de elasticidade com maiores deformações.

\subsection{Comparativos}

Os ensaios nos diversos tipos de solos, utilizando um material de reforço com dimensões constantes durante os ensaios, gerou uma gama de dados que mostra a diferença de magnitudes de deslocamento do reforço e comportamentos dos solos quanto às variações de tensões normais e cargas de cisalhamento aplicadas no reforço.

\subsubsection{Arrancamento}

Os ensaios de arrancamento em areia, silte e brita foram feitos utilizando-se o mesmo material de reforço com as mesmas características de dimensões e comprimento de ancoragem, e forneceram alguns valores característicos sintetizados na Tabela 4.1 a seguir.

O ensaio em areia apresenta aumento da força máxima de arrancamento juntamente com o aumento do deslocamento da garra, conforme é aumentada a tensão confinante $(\sigma)$. A força máxima para o deslocamento interno também cresce com o aumento da força de 
arrancamento, já a deformação máxima apresenta tendência de crescimento conforme a tensão confinante aumenta, mostrando maior ancoragem do material sobre maiores tensões confinantes.

Tabela 4.1 - Resultados de arrancamento em areia, silte e brita.

\begin{tabular}{|c|c|c|c|c|c|}
\hline Solo & $\sigma_{\text {confinante }}$ & Força Máxima & $\begin{array}{c}\text { Deslocamento } \\
\text { da garra na } \\
\text { força máx. }\end{array}$ & $\begin{array}{l}\text { Força máx. para } \\
\text { desloc. Interno } \\
\text { total }^{1}\end{array}$ & $\begin{array}{c}\text { Deformação } \\
\text { máx. para } \\
\text { desloc. Interno } \\
\text { total }^{2}\end{array}$ \\
\hline & $(\mathrm{kPa})$ & $(\mathrm{kN} / \mathrm{m})$ & $(\mathrm{mm})$ & $(\mathrm{kN} / \mathrm{m})$ & $(\mathrm{mm})$ \\
\hline \multirow{4}{*}{ Areia } & 25 & 18,0 & 58 & 11,8 & 4,6 \\
\hline & 40 & 21,6 & 61 & 14,0 & 5,5 \\
\hline & 55 & 24,4 & 71 & 15,0 & 5,0 \\
\hline & 70 & 28,6 & 78 & 20,0 & 10,0 \\
\hline \multirow{3}{*}{ Silte } & 25 & 23,3 & 69 & 12,5 & 4,0 \\
\hline & 40 & 23,2 & 65 & 12,5 & 4,5 \\
\hline & 55 & 24,2 & 54 & 20,0 & 7,5 \\
\hline \multirow{3}{*}{ Brita } & 25 & 23,0 & 70 & 7,5 & 3,0 \\
\hline & 40 & 24,8 & 61 & 11,6 & 3,0 \\
\hline & 55 & 22,0 & 60 & 5,8 & 2,4 \\
\hline
\end{tabular}

1 - Força máxima registrada no instante de início de deslocamento do ponto mais ancorado do reforço (deslocamento integral do reforço).

2 - Deslocamento relativo máximo entre o ponto mais próximo à aplicação de carga e o início do deslocamento do ponto mais distante da aplicação da carga (deformação máxima).

O silte e a brita mostraram que a tensão normal praticamente não influenciou a força de arrancamento medido. No entanto, para o silte, o deslocamento da garra para a força máxima de arrancamento se mostrou menor conforme era aumentada a tensão confinante, apresentando uma tendência de enrijecimento do solo confinante. Assim como na areia, no silte o aumento da tensão confinante promove um aumento do deslocamento máximo interno da amostra, acompanhando também a magnitude de deslocamentos da areia e mostrando maior ancoragem conforme a tensão é aumentada. 
Para a brita, o deslocamento da garra também decrescia conforme era aumentada a tensão confinante, aparentando um enrijecimento do solo. A força máxima para mobilização da amostra mostrou-se menor e inconstante em relação à da areia e a do silte, já o deslocamento máximo interno da amostra foi de cerca de metade dos valores do silte e da areia. Os ensaios de arrancamento em Brita terminavam com o rompimento da amostra após a solicitação de todo o corpo de prova, em uma força próxima à força máxima de arrancamento. Tal conclusão se embasa na análise de deslocamentos que ocorriam ao longo de todo o reforço e mostravam tendência de estabilização, logo antes das rupturas.

A análise das células de tensão induz ao entendimento de que a solicitação do corpo de prova leva ao desconfinamento gradual do reforço em primeiro instante, seguido do reconfinamento que ocorria com o arraste do reforço em direção à manga. Os deslocamentos sofridos pelo reforço na parte próxima à aplicação de força promoviam um rearranjo dos grãos de brita próxima à entrada da manga, que danificavam a geogrelha conforme a mesma era tracionada para fora da caixa de ensaios por entre os grãos de brita maiores, que ficavam travados na abertura da manga, levando à ruptura do reforço.

\subsubsection{Ciclagem}

Assim como os ensaios de arrancamento, os ensaios cíclicos foram realizados utilizando o mesmo reforço e iguais características de medições. Igualmente às diferenças dos solos quanto ao arrancamento, na ciclagem ocorreram diferenças quanto a deslocamentos e módulo de resiliência. A instrumentação aplicada da mesma forma nos diferentes ensaios permite a comparação entre os resultados de comportamento nos diferentes solos, mostrados na Tabela 4.2 a seguir. 
Tabela 4.2 - Comportamento cíclico da areia, do silte e da brita.

\begin{tabular}{|c|c|c|c|c|c|c|}
\hline Solo & $F_{\text {máx }}$ & $\sigma_{\text {confinante }}$ & $\begin{array}{l}\text { Deslocamento } \\
\text { médio por ciclo }\end{array}$ & $\begin{array}{l}\text { Deslocamento } \\
\text { acumulado nos } \\
\text { ciclos }\end{array}$ & $\begin{array}{c}\text { Tensão } \\
\text { Cisalhante }\end{array}$ & $\begin{array}{c}\text { Mód. } \\
\text { Resiliencia } \\
\left(G_{i}\right)\end{array}$ \\
\hline & & $(\mathrm{kPa})$ & $(\mathrm{mm})$ & $(\mathrm{mm})$ & $(\mathrm{kPa})$ & $(k P a / m)$ \\
\hline \multirow{9}{*}{ Areia } & \multirow{3}{*}{$20 \%$} & 25 & 0,358 & \multirow{3}{*}{0,229} & 3,8 & $9,7 \mathrm{E}+03$ \\
\hline & & 40 & 0,361 & & 4,3 & $1,1 \mathrm{E}+04$ \\
\hline & & 55 & 0,376 & & 5,0 & $1,1 \mathrm{E}+04$ \\
\hline & \multirow{3}{*}{$40 \%$} & 25 & 0,748 & \multirow{3}{*}{0,515} & 7,5 & $9,8 \mathrm{E}+03$ \\
\hline & & 40 & 0,783 & & 8,6 & $1,1 \mathrm{E}+04$ \\
\hline & & 55 & 0,738 & & 9,4 & $1,2 \mathrm{E}+04$ \\
\hline & \multirow{3}{*}{$60 \%$} & 25 & 1,315 & \multirow{3}{*}{4,867} & 10,6 & $7,8 \mathrm{E}+03$ \\
\hline & & 40 & 1,687 & & 12,9 & $7,5 \mathrm{E}+03$ \\
\hline & & 55 & 1,857 & & 14,4 & $7,7 E+03$ \\
\hline \multirow{12}{*}{ Silte } & \multirow{3}{*}{$20 \%$} & 25 & 0,117 & \multirow{3}{*}{0,038} & 5,0 & $4,2 E+04$ \\
\hline & & 40 & 0,101 & & 5,2 & $4,7 \mathrm{E}+04$ \\
\hline & & 55 & 0,086 & & 5,4 & $5,4 \mathrm{E}+04$ \\
\hline & \multirow{3}{*}{$40 \%$} & 25 & 0,225 & \multirow{3}{*}{0,063} & 9,6 & $4,3 E+04$ \\
\hline & & 40 & 0,198 & & 9,8 & $4,9 E+04$ \\
\hline & & 55 & 0,189 & & 10,2 & $5,4 E+04$ \\
\hline & \multirow{3}{*}{$60 \%$} & 25 & 0,430 & \multirow{3}{*}{0,409} & 14,1 & $3,2 E+04$ \\
\hline & & 40 & 0,402 & & 14,5 & $3,5 E+04$ \\
\hline & & 55 & 0,535 & & 14,8 & $2,7 E+04$ \\
\hline & \multirow{3}{*}{$80 \%$} & 25 & 1,225 & \multirow{3}{*}{0,742} & 18,5 & $1,5 E+04$ \\
\hline & & 40 & 1,186 & & 18,8 & $1,6 \mathrm{E}+04$ \\
\hline & & 55 & 1,174 & & 19,1 & $1,6 E+04$ \\
\hline \multirow{9}{*}{ Brita } & \multirow{3}{*}{$20 \%$} & 25 & 0,125 & \multirow{3}{*}{0,044} & 5,3 & $4,1 E+04$ \\
\hline & & 40 & 0,090 & & 5,4 & $5,6 E+04$ \\
\hline & & 55 & 0,062 & & 5,5 & $8,2 E+04$ \\
\hline & \multirow{3}{*}{$40 \%$} & 25 & 0,264 & \multirow{3}{*}{0,357} & 9,9 & $3,8 \mathrm{E}+04$ \\
\hline & & 40 & 0,211 & & 10,1 & $4,7 E+04$ \\
\hline & & 55 & 0,174 & & 10,0 & $5,4 \mathrm{E}+04$ \\
\hline & \multirow{3}{*}{$60 \%$} & 25 & 0,950 & \multirow{3}{*}{$\sim \sim$} & 14,4 & $2,2 E+04$ \\
\hline & & 40 & $\sim \sim$ & & $\sim \sim$ & $\sim \sim$ \\
\hline & & 55 & $\sim \sim$ & & $\sim \sim$ & $\sim \sim$ \\
\hline
\end{tabular}

Os ensaios com areia possibilitaram a construção de uma envoltória de arrancamento, com aumento de carga para cada aumento de confinante em cada nível de solicitação (20, 40 e 
$60 \%$ da $F_{\text {máx }}$, já o silte e a brita, como não obtiveram envoltória, dentro de cada nível de solicitação (20, 40 e $60 \%$ da $F_{\text {máx }}$ ) era aumentada a tensão confinante e a carga praticamente se mantinha. Na areia, com o aumento da tensão cisalhante ocorria o aumento dos deslocamentos médios por ciclo, desde $20 \%$ da $F_{\text {máx }}$ até $60 \%$ da $F_{\text {máx mesmo com os }}$ respectivos aumentos da confinante. Foram registrados aumentos nos deslocamentos médios acumulados nos ciclos realizados em 20,40 e $60 \%$ da $F_{\text {máx }}$ sendo que na tensão relativa a 40 $\%$ da $F_{\text {máx }} \mathrm{o}$ deslocamento foi cerca de duas vezes maior do que o deslocamento registrado com $20 \%$ da $F_{\text {máx }}$ e o deslocamento referente a $60 \%$ da $F_{\text {máx }}$ foi cerca de 20 vezes maior que o de $20 \%$ da $F_{\text {máx }}$ indicando que com este nível de solicitação o reforço apresenta maior instabilidade, tendendo ao arrancamento.

Ainda na areia, o módulo $G_{i}$ aumentava conforme era aumentada a tensão confinante para os níveis de 20 e $40 \%$ da $F_{\text {máx }}$. Para o nível de $60 \%$ da $F_{\text {máx }}$ o módulo $G_{i}$ se apresentou menor do que nos níveis de solicitação inferiores, devido ao grande acúmulo de deslocamentos neste nível de solicitação.

No ensaio cíclico com silte a tensão cisalhante era ligeiramente aumentada conforme era aumentada a tensão confinante, porém, diferentemente da areia, no silte o deslocamento por ciclo diminuía conforme era aumentada a tensão confinante dentro de um mesmo nível de solicitação $\left(20,40\right.$ e $80 \%$ da $\left.F_{\text {máx }}\right)$. Foram registrados aumentos nos deslocamentos médios conforme era aumentado o nível de tensão cisalhante $\left(20,40,60\right.$ e $80 \%$ da $\left.F_{\text {máx }}\right)$ semelhante ao da areia, porém, em uma magnitude média cerca de oito vezes menor. No ensaio com brita os deslocamentos diminuíam conforme era aumentada a confinante, dentro dos níveis de 20 e $40 \%$ da $F_{\text {máx }}$. Para o nível de tensão de $60 \%$ da $F_{\text {máx }}$ ocorreu ruptura da amostra por abrasão na brita confinante com o nível de deslocamento médio de cerca de um $\mathrm{mm}$, associando-se aos deslocamentos anteriores que também degradaram a amostra em menores níveis. 
No Silte o módulo $G_{i}$ era cerca de quatro vezes o valor da areia e também apresentava tendência de diminuir conforme era aumentado o nível de solicitação devido ao maior nível de deslocamentos. Na brita, os módulos $G_{i}$ foram ligeiramente maiores que no silte e aumentavam consideravelmente conforme era aumentada a tensão confinante, diferentemente dos outros solos.

Entre os três tipos de solos ensaiados a areia apresentou a menor ancoragem, mesmo com o aumento da confinante, porém não promoveu danos ao reforço mesmo sobre ciclagem e permitiu distribuição das tensões por todo o corpo de prova durante as solicitações, mostrado através dos deslocamentos registrados.

O silte apresentou a melhor ancoragem entre os três, mantendo deslocamentos relativamente pequenos com o aumento do nível de solicitação e apresentando os menores deslocamentos entre a areia e a brita desde o início da ciclagem. Com o aumento da tensão confinante os deslocamentos diminuíam ainda mais, apresentando melhora na interação soloreforço. Foi possível ainda realizar a ciclagem com $80 \%$ da $F_{\text {máx }}$ sem danos ao reforço.

O comportamento do silte mostra deslocamento do reforço não homogêneo, apresentando pequenos deslocamentos repentinos conforme o local de medição se desprendia do solo. Este foi o solo que melhor interagiu com o reforço, apresentando a maior diferença entre os deslocamentos registrados na parte frontal (próxima à aplicação de força) e na parte traseira (mais distante da aplicação da força), mostrando bom ancoramento.

A ciclagem com Brita apresentou grande degradação ao reforço antes da realização de 1000 ciclos. A ciclagem mobilizava a fração mais fina da brita graduada e desancorava a parte frontal (próxima à manga), causando um rearranjo do solo e deixando os grãos maiores de 
brita ainda fixos e em contato com a geogrelha que se deslocava com a ciclagem, agredindo e rompendo o reforço e impedindo a aplicação de muitos ciclos.

A brita apresentou comportamento distinto da Areia a do Silte, se comportando parte como o material granular e parte como o solo fino. O deslocamento do reforço ocorre de maneira semelhante a o da Areia, mobilizando todo o reforço com o início da tração, porém, a escala de deslocamentos e comportamento resiliente é semelhante ao do Silte. O comportamento geral da brita se mostrou agressivo em relação ao reforço.

No geral os resultados acerca dos valores de módulo de resiliência ficaram abaixo dos valores encontrados na literatura, porém, na literatura são utilizados reforços mais rígidos e com comprimentos de ancoragens menores, gerando níveis de tensões menores e consequentemente deslocamentos menores, o que mantém o solo mais rígido e faz com que os módulos de resiliência sejam maiores do que os obtidos nesta pesquisa. 


\section{Conclusão}

\subsection{Equipamento}

Para a concepção dos ensaios foram realizadas modificações em um equipamento de ensaios de arrancamento já existente, buscando precisão na carga e no tempo de ciclagem, melhora na aquisição de deslocamentos e instalação de sistema de segurança no ensaio.

As modificações resultaram na obtenção de precisão de cerca de 0,001 $\mathrm{mm}$ para a medição de deslocamentos do reforço, e melhor controle da amplitude de carga, bem como dos tempos de ciclagem, além de maior precisão na velocidade do ensaio de arrancamento monotônico. O sistema de segurança implantado na programação do Controlador Lógico Programável também funcionou como esperado, fornecendo segurança aos ensaios e uma interface com mais informações instantâneas acerca do ensaio. O sistema de fixação da geogrelha permitiu diminuir os escorregamentos do reforço na garra.

\subsection{Solo reforçado}

O comportamento de sistemas de solo reforçado foi estudado por meio de ensaios de arrancamento monotônico e cíclico, utilizando três solos diferentes e uma mesma geogrelha.

Os ensaios de arrancamento em areia apresentaram aumento na resistência conforme a tensão confinante era aumentada, variando de 18 a $25 \mathrm{kN} / \mathrm{m}$ para tensões confinantes de 25 a $55 \mathrm{kPa}$, enquanto no silte e na brita a tensão confinante pareceu não influenciar de maneira representativa na resistência máxima, resultando em cerca de $23 \mathrm{kN} / \mathrm{m}$ para ambos. Durante o arrancamento, a brita permite que o reforço seja solicitado integralmente com cargas menores 
frente aos outros materiais confinantes, porém, em níveis de deslocamentos menores que o da areia, e próximos ao do silte. No silte os deslocamentos ocorreram de maneira mais abrupta e aparentemente o reforço se movimentava em "seções" conforme a solicitação aumentava.

Tanto nos ensaios de arrancamento quanto nos cíclicos, nos três solos os níveis de carregamentos mais baixos geravam maior variação de tensões e deslocamentos mais próximos à aplicação das forças (frente), que tendiam a aumentar nas partes mais distantes da aplicação das forças (fundo), conforme a solicitação era aumentada. No silte e, principalmente na brita, o início da tração gerava ainda uma diminuição nas tensões totais próximas à aplicação de força (frente), causadas pelo desconfinamento e seguidas de um acréscimo nestas tensões de maneira gradual ao longo do reforço. Conforme a tensão aumentava na parte mediana e traseira da amostra a tensão começava a cair na parte mais à frente, devido a um desconfinamento causado pelo deslocamento do reforço em todos os solos. A solicitação do reforço em regiões menos confinadas (frente) causava ainda o arraste dos elementos transversais, juntamente com os longitudinais. Já, em regiões mais confinadas, ocorria o desprendimento do elemento longitudinal nos três tipos de solos.

A areia foi o material confinante que apresentou os maiores níveis de deslocamentos e a maior perda de material com a ciclagem. Apresentou comportamento cíclico estável até o nível de $40 \%$ da $F_{\text {máx }}$ e tendendo a estabilizar os deslocamentos com a continuação dos ciclos. Passou a mostrar instabilidade a partir de $60 \%$ da $F_{\text {máx }}$ onde os deslocamentos aumentavam sem tendência de estabilização. O comportamento cíclico do Silte foi o mais estável entre os três, gerando desde o início deslocamentos relativamente pequenos que se mantinham e começavam a aumentar apenas na solicitação de $60 \%$ da $F_{\text {máx }}$, apresentando aumento considerável com carregamento de $80 \%$ da $F_{\text {máx. }}$. No início do ensaio com a brita, os deslocamentos ao longo do corpo de prova ocorriam semelhantes à areia, porém, em 
magnitude semelhante à do silte. Eles se mantinham no primeiro nível de carregamento $20 \%$ da $F_{\text {máx }}$ e no nível de $40 \%$ da $F_{\text {máx }}$ mostravam pequeno aumento, porém, com tendência a aumentar. Já no início do ensaio com nível de $60 \%$ da $F_{\text {máx }}$ os deslocamentos aumentaram vertiginosamente e ocorreu ruptura do reforço logo no início deste nível, devido à abrasão, mostrando ser um solo muito agressivo, e dificultando o estudo do seu comportamento.

Os módulos de resiliência de cisalhamento de interface $\left(G_{i}\right)$ obtidos com a areia variaram entre 7.500 e $11.800 \mathrm{kPa} / \mathrm{m}$, com alteração relativamente pequena no módulo devido ao aumento da tensão confinante e da cisalhante. No silte foram obtidos valores entre 54.000 e $16.000 \mathrm{kPa} / \mathrm{m}$, porém, esta variação se deve fundamentalmente à variação da tensão cisalhante. A brita apresentou variação no módulo $G_{i}$ de 80.000 a $20.000 \mathrm{kPa} / \mathrm{m}$, e tal variação se deve à variação da confinante e da cisalhante em iguais proporções. Em todos os ensaios cíclicos os módulos de resiliência obtidos foram abaixo dos relatados na literatura, que utiliza em sua maioria reforços mais rígidos e comprimentos de ancoragens significativamente menores, gerando menores forças cisalhantes e consequentemente provocando menores deformações na amostra, no solo e afetando diretamente o módulo de resiliência. 


\title{
6. Bibliografia
}

\author{
ABNT NBR 12553 (2003) - Geossintéticos - Terminologia \\ ABNT NBR 6502 (1995) - Rochas e Solos - Terminologia.
}

ALFARO, M.C.; HAYASHI, S., MIURA, N. and WATANABE, K., (1995) - Pullout Interaction Mechanism of Geogrid Strip Reinforcement. Geosynthetics International, Vol. 2, No. 4, p.679-698.

ANTUNES, L. G. S. (2008) - Reforço de pavimentos rodoviários com geossintéticos. Dissertação apresentada à Universidade de Brasília. Faculdade de Tecnologia, 156p.

ASTM D 4439 (2002) - Standard Terminology for Geosynthetics.

ASTM D 6637 (2001) - Standard Test Method for Determining Tensile Properties of Geogrids by the Single or Multiple-rib Tensile Method.

ASTM D 6706 (2001) - Standard Test Method for Measuring Geosynthetic Pullout Resistance in Soil.

ASTM D 7499/D7499M (2009) - Standard Test Method for Measuring Geosynthetic-soil Resilient Interface Shear Stiffness.

ATKINSON, J. H. (2000) - Non-linear soil stiffness in routine design. Géotechnique 50, No. 5, p.487-508.

BATHURST, R. J.; CAI, Z. (1994) - In-Isolation Cyclic Load-Extension Behavior of Two Geogrids. Geosynthetics International, Vol. 1, No.1, 19p.

BOWMAN, J. R. et al. (2012) - Development of odot guidelines for the use of geogrids in aggregate bases. U. S. Department of Transportation, Federal Highway Administration, FHWA Report Reference Number FHWA-OK-12-04, Washington D.C., USA.

CARMO, C. A. T.; D’ÁVILLA, C. A. (2011) - Análise de deformação em um pavimento reforçado com geogrelha. VI Simpósio Brasileiro de Geossintéticos - REGEO 2011, Tema 12, Geossintéticos em rodovias e ferrovias, ID-170, $7 \mathrm{p}$.

CUELHO, E.V.; PERKINS, S.W. (2005) - Resilient interface shear modulus from shortstrip, cyclic pullout tests. In: M.A. Gabr, J.J. Bowders, D. Elton and J.G. Zornberg (Editors). ASCE, Austin, Texas, USA, 11p. 
DNER, (1996) - Manual de pavimentação, Departamento nacional de estradas e rodagens, Pavimentação - manuais I, série II titulo CDD 625.80202, 320p.

DNER-ME 131 (1994) - Solos - determinação do módulo de resiliência. Departamento nacional de estradas e rodagens, Método de Ensaio, 8p.

FAKHER, A.; JONES, C. J. F. P. (1997) - A New Unit-Cell to Study the Deformation Mechanism of Super Soft Clay Overlaid by Geogrid and Sand. Geosynthetics International, Vol. 3, No. 3, p.349-367.

GARCÍA, G. F. N. (2011) - Implementação de ensaios de arrancamento cíclico de geossintéticos. Dissertação apresentada à Escola de Engenharia de São Carlos EESC-USP, 99p.

GUPTA, B. E. R. (2009) - A study of geosynthetic reinforced flexible pavement system. Tese apresentada à The University of Texas at Austin, 281p.

HOLLEY, T. M. (2009) - Development of a test protocol for cyclic pullout of geosynthetics in roadway base reinforcement. Tese apresentada à Montana State University, Bozeman, Montana, 99p.

KAKUDA, F. M. (2005) - Estudo de ensaios de arrancamento de geogrelha com utilização de um equipamento reduzido. Dissertação apresentada à Escola de Engenharia de São Carlos EESC-USP, 145p.

KAKUDA, F. M. (2010) - Desenvolvimento e a utilização de um equipamento de grandes dimensões na análise do comportamento mecânico de uma seção de pavimento sob carregamento cíclico. Tese apresentada à Escola de Engenharia de São Carlos EESC-USP, 290p.

KOERNER, R. M. (2005) - Designing With Geosynthetics. $5^{\text {th }}$ Edition, 796p.

KONGKITKUL, W.; Hirakawa, D.; Tatsuoka, F.; Uchimura, T. (2004) - Viscous deformation of geosynthetic reinforcement under cyclic loading conditions and its model simulation. Geosynthetics International, 11, No. 2, p.73-99.

LENG, J.; GABR, M. A. (2002) - Characteristics of Geogrid-Reinforced Aggregate Under Cyclic Load. Transportation Research Board of the Nacional Academies, Vol. 1786/2002 p.29-35.

LING, H. I.; WANG, J. P. (2008) - Cyclic behavior of soil-structure interfaces associated with modular-block reinforced soil-retaining walls. Geosynthetics international, Vol. 15, No. 1, p.14-21. 
LOPES, M. J.; LOPES, M. L. (2000) - Soil-Geosynthetic Interaction - Influence of Soil Particle Size and Geosynthetic Structure. Geosynthetics international, Vol. 6, No. 4, p.261282.

LOPES, M. L.; LADEIRA, M. (1996) - Role of Specimen Geometry, Soil Height and Sleeve Length on the Pull-Out Behavior of Geogrids. Geosynthetics international, Vol. 3, No. 6, p.701-719.

MARMITT, H. M.; CASAGRANDE, M, D. T.; CERATTI, J. A. P. (2010) - Caracterização de propriedades resilientes de três britas graduadas utilizadas em pavimentos no sul do Brasil. Teoria e prática na engenharia civil, $\mathrm{n}^{\circ} 15, \mathrm{p} .63-69$.

MENDOZA, F. M. L.; LÁZARES, W. G. (2003) - Ensayo de modulo resiliente. XIV congresso nacional de ingenieria civil, iquitos, 2003, $21 \mathrm{p}$.

MEYER, N.; NERNHEIM, A.; KÖHLER, U. (2004) - Geosynthetic-soil interaction under cyclic loading. Proceedings of the Third European Geosynthetics Conference EuroGeo 3, p.635 - 639 .

MORATI, N.; CARDILLE, G. (2009) - Influence of cyclic tensile loading on pullout resistance of geogrids embedded in a compacted granular soil. Geotextiles and Geomembranes 27, p.475-487.

MORATI, N.; GIUSEPPE, G. (2012) - Deformative behavior of different geogrids embedded in a granular soil under monotonic and cyclic pullout loads. Geotextiles and Geomembranes 32, p.104-110.

MORATI, N.; RECALCATI, P. (2006) - Factors affecting the pullout behavior of extruded geogrids embedded in a compacted granular soil. Geotextiles and Geomembranes 24, p.220242.

NCHRP (2000) - Harmonized Test Methods for Laboratory Determination of Resilient Modulus for Flexible Pavement Design. Vol 1: Unbound Granular Material, National Cooperative Highway Research Program, Project 1-28a Draft Report, 198p.

NCHRP (2004) - Laboratory determination of resilient modulud for flexible pavement design, Research results digest. National Cooperative Highway Research Program, 52p.

PALMEIRA, E. M. (2009) - Soil-geosynthetic interaction: Modelling and analysis. Geotextiles and Geomembranes 27, p.368-390.

PALMEIRA, E. M.; ANTUNES, L.G.S. (2010) - Large scale tests on geosynthetic reinforced unpaved roads subjected to surface maintenance. Geotextiles and Geomembranes 28, p.547558. 
PERKINS, S.W. (2000) - Constitutive Modeling of Geosynthetics - Elsevier Science Ltd. Geotextiles and Geomembranes, Vol. 18 p.273-292.

PERKINS, S.W. et al. (2004) - Development of Design Methods for Geosynthetic Reinforced Flexible Pavements. U.S. Department of Transportation, Federal Highway Administration, FHWA Report Reference Number DTFH61-01-X-00068, Washington D.C., USA.

PERKINS, S.W.; ISMEIK, M. (1997) - A Synthesis and Evaluation of GeosyntheticReinforced Base Layers in Flexible Pavements: Part I. Geosynthetics International, Vol. 4, No. 6, p.549-604.

PIMENTEL, K. C. A. (2007) - Estradas não-pavimentadas e Ferrovias reforçadas com geossintéticos. Tese da Universidade de Brasília. Faculdade de Tecnologia, 293p.

RAJU, D. M.; FANNIN, R. J. (1997) - Monotonic and cyclic pull-out resistance of geogrids. Géotechnique 47, No. 2, p.331-337.

SEED, H. B.; IDRISS, I. M. (1970) - Soil moduli and damping factors for dynamic response analyses. College of Engineering, University of California, Berkeley, California, 42p.

TAKEDA, M. C. (2006) - A influência da variação da umidade pós-compactação no comportamento mecânico de solos de rodovias do interior paulista. Tese apresentada à Escola de Engenharia de São Carlos EESC-USP, 276p.

TEIXEIRA, S. H. C. (2003) - Estudo da interação solo-geogrelha em testes de arrancamento e a sua aplicação na análise e dimensionamento de maciços reforçados. Tese apresentada à Escola de Engenharia de São Carlos EESC-USP, 218p.

USACE (2003) - Use of geogrids in pavement construction. Department of the army U. S. Army Corps of Engineers, Techinical letter No. 1110-1-189, Washington DC, 2003, 38p.

VERTEMATTI, J. C. (2004) - Manual Brasileiro de Geossintéticos - Associação Brasileira das indústrias de não tecidos e tecidos técnicos - ABINT

ZAMBRANO, J. A. F. (2007) - Estudo de reforço de pavimentos com ensaios de arrancamento em equipamento de pequenas dimensões. Dissertação apresentada à Escola de Engenharia de São Carlos EESC-USP, 114p.

ZORNBERG, J. G. (2011) - Advances in the usa of geosynthetics in pavement design. Geosynthetics India, IIT Madras, Chennai, 19p. 


\section{Anexos}

\subsection{Programações do CLP do equipamento de ensaios de arrancamento e cíclicos}

O sistema de carregamentos de arrancamento é realizado através de um atuador hidráulico controlado por um Controlador Lógico Programável (CLP) com capacidade de arrancamento dimensionada para aproximadamente $5000 \mathrm{~kg}$.

No capítulo 3.1 (página 54), deste trabalho encontram-se especificações e modificações realizadas no equipamento, entre eles o detalhamento das configurações do CLP em relação a capacidades máximas e mínimas, resolução máxima de cada parâmetro programável, os sistemas de aplicação das sobrepressões no solo, os sistemas de medição de deslocamentos e o funcionamento da pressão e fluxo de óleo do sistema. As programações e respectivos campos das telas de programações do CLP são mostrados a seguir.

A tela inicial do CLP é ilustrada na Figura 7.1 a seguir e mostra o deslocamento do pistão (com a garra), a carga e a contagem dos ciclos atuais, atualizados instantaneamente ao longo do ensaio.

Aparece ainda na tela inicial o número da programação, que pode ser definida em 100 números diferentes (0 a 99) e é referente às entradas de parâmetros de carga, ciclo e curso do pistão, além da constante da célula de carga. 


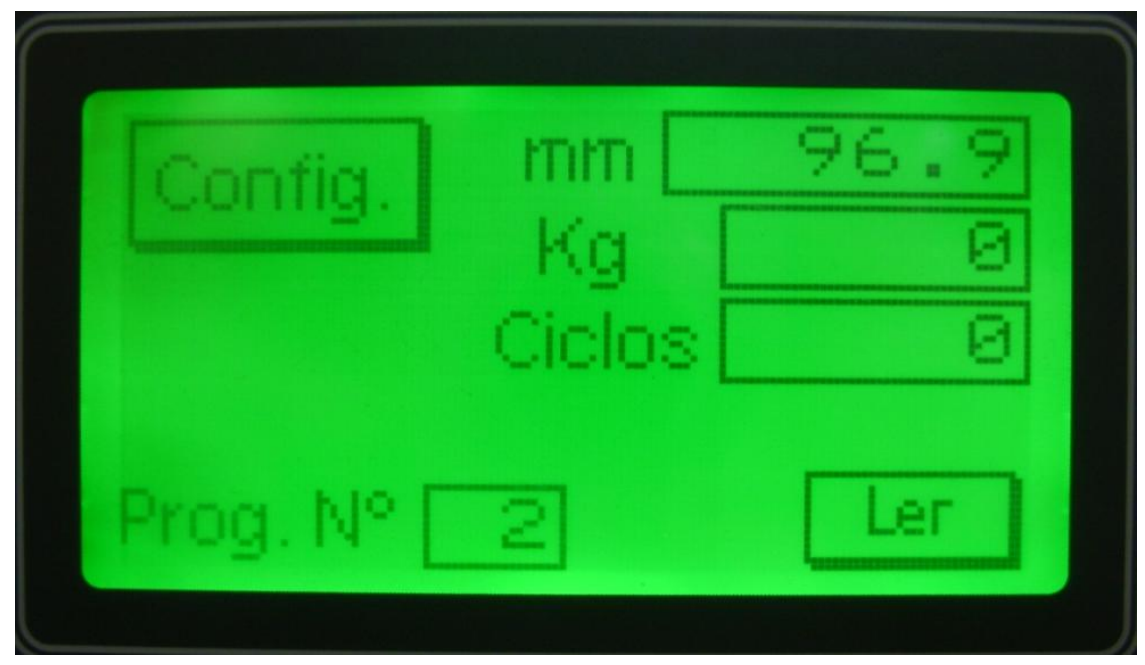

Figura 7.1 - Tela inicial do CLP.

Selecionando-se o campo "Config." o mostrador é direcionado para a tela ilustrada na Figura 7.2 a seguir e apresenta as configurações referentes à carga, ciclo, curso, parâmetros de controle e opção de salvar estes parâmetros no número inserido na tela inicial.

Nesta tela "Config." assim como nas telas "Carga", "Ciclo", "Controle" e "Curso" subsequentes é possível retornar à respectiva tela anterior selecionando-se o campo " $<<$ ".

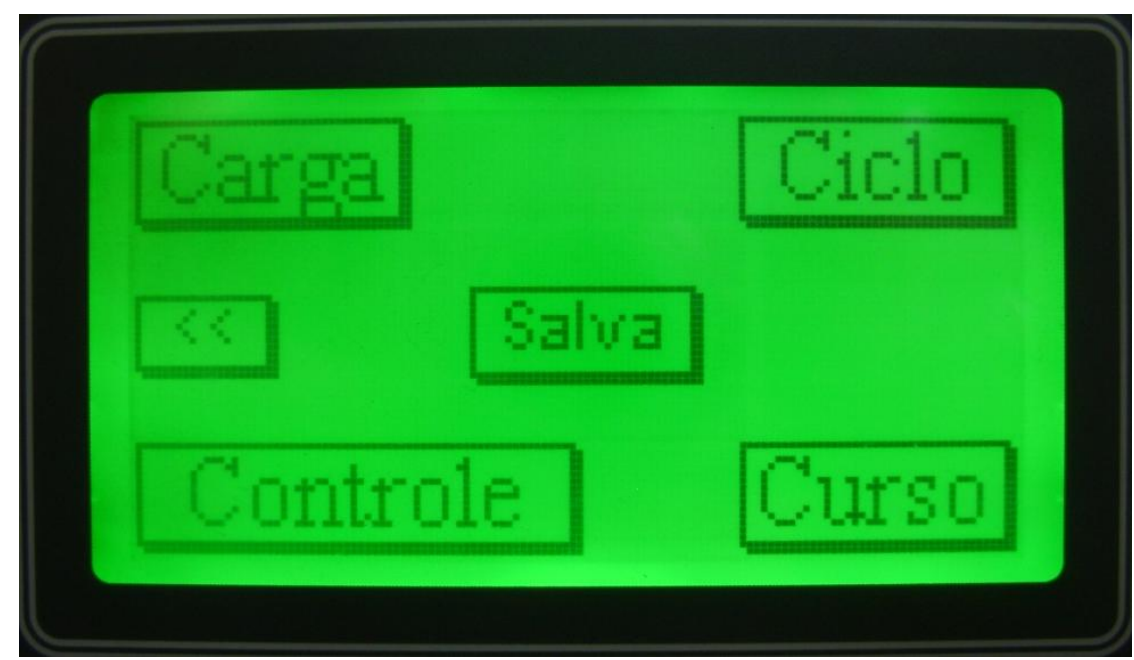

Figura 7.2 - Tela "Config." do CLP. 
Selecionando-se a opção "Carga” no mostrador aparecerá a tela ilustrada na Figura 7.3 a seguir, que apresenta parâmetros de limite de carga maior $(\mathrm{Kg})$, menor $(\mathrm{Kg})$ e velocidade do pistão $(\mathrm{mm})$ respectivamente. O limite maior é referente à carga máxima aplicada durante uma ciclagem (pulso) ou um arrancamento, estando limitada à resistência do elemento mais fraco do sistema (célula de carga de menor capacidade por exemplo).

O limite menor é a carga mínima aplicada ao sistema durante a ciclagem (carga de assentamento) e a carga de retorno do sistema se atingida a carga máxima de arrancamento.

Para a realização de ensaios de arrancamento deve-se programar uma carga máxima que o sistema provavelmente não irá alcançar antes de ocorrer o arrancamento, pois se alcançar esta carga, será iniciada a ciclagem e ocorre o retorno à carga mínima.

O campo de velocidade do pistão é onde se define a velocidade de rotação do motor, que após calibração foi transformada em velocidade do pistão, que quando apresenta fluxo livre (sem estrangulamento do óleo através de válvulas) varia de 1 a $53 \mathrm{~mm} / \mathrm{s}$, e afeta diretamente a velocidade do ciclo e do arrancamento.

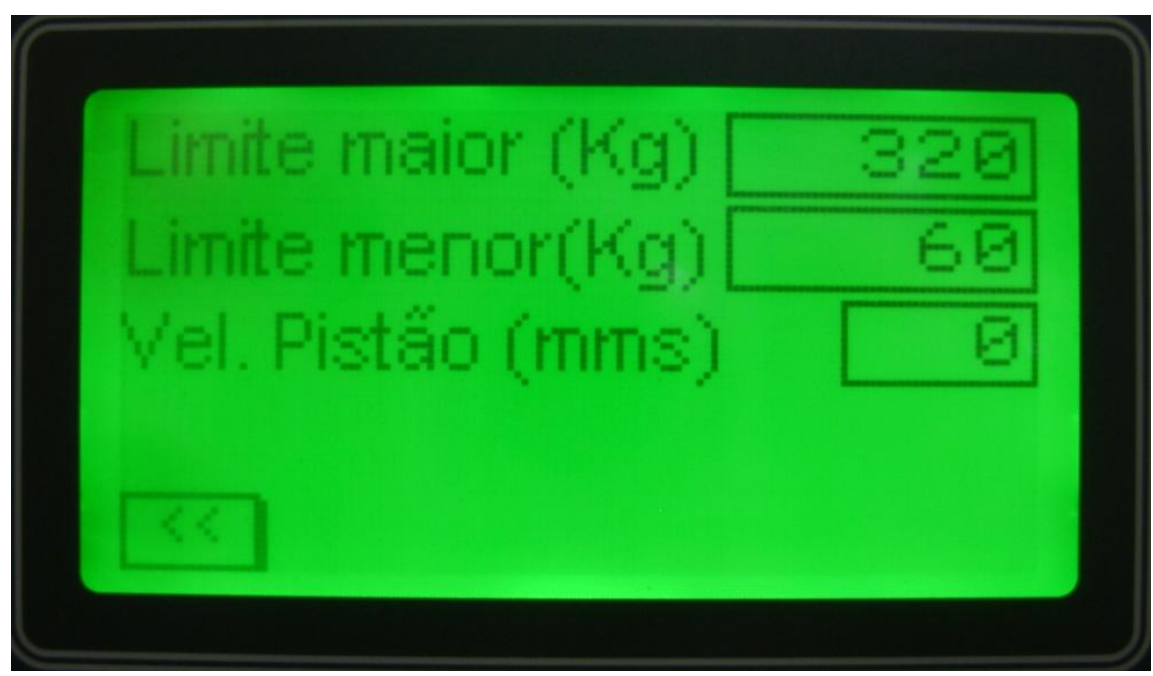

Figura 7.3 - Tela "Carga" do CLP. 
Retornando à tela "Config." e selecionando o campo "Ciclo" no mostrador aparece a tela ilustrada na Figura 7.4 a seguir, onde se tem campos de entrada de tempo do ciclo (s), tempo de parada (s) e número de ciclos respectivamente. No campo "T. ciclo" é inserido o tempo de duração do pulso completo, desde o carregamento buscando a carga máxima até o retorno à carga mínima. O tempo de parada ("T. parada") é o tempo de descanso do sistema permanecendo na carga mínima antes do início do próximo pulso.

Os valores de tempo de ciclagem estão diretamente relacionados a outros fatores como velocidade do pistão, fluxo de óleo e distância percorrida pelo pistão para a carga máxima, podendo não alcançar o tempo programado se as outras configurações não estiverem coerentes.

O campo de número de ciclos ou "No ciclos" é inserido o número de ciclos desejado no período de ciclagem.

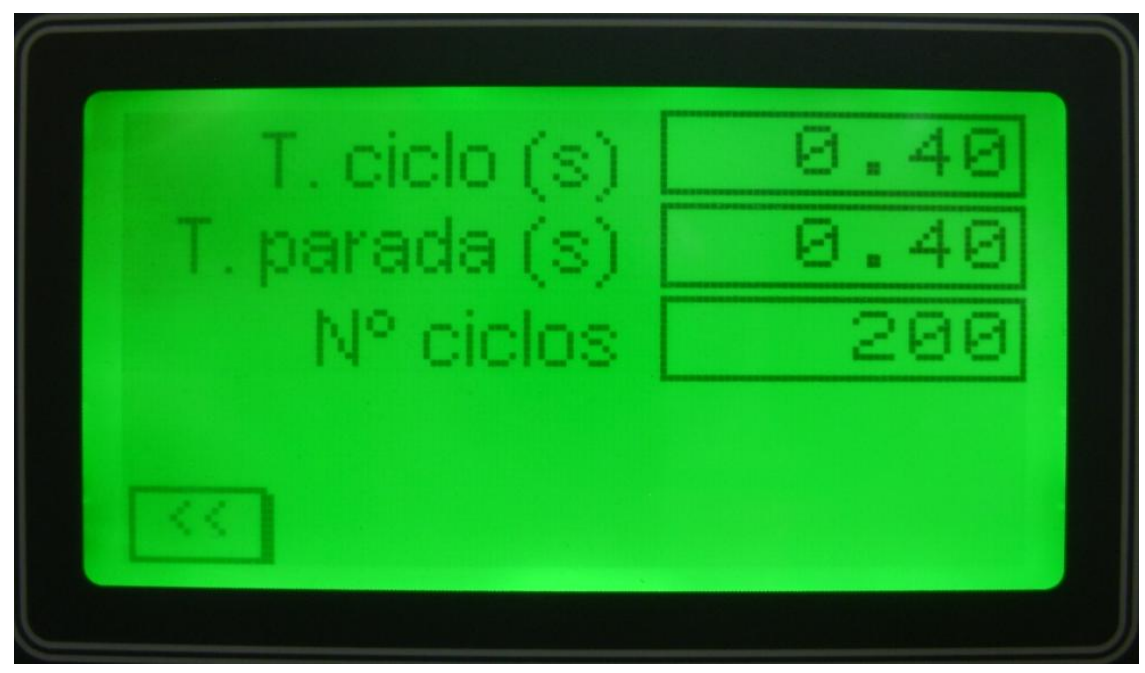

Figura 7.4 - Tela "Ciclo" do CLP.

Retornando-se à tela "Config." do CLP e selecionando-se o campo "Curso" representado na Figura 7.5 a seguir, é possível alterar parâmetros do curso do pistão (consequentemente da garra) onde se têm a posição atual da garra no campo " $m m$ ", o 
deslocamento mínimo em relação à aproximação com a caixa (valor negativo em milímetros), e o deslocamento máximo distanciando-se da caixa de ensaios (valor positivo em milímetros). O campo "atual" a baixo do mostrador insere a posição da garra manualmente, e depois de selecionado o campo "atual” o valor inserido passa a ser o valor da posição da garra no campo ( $\mathrm{mm}$ ) acima. Os valores de deslocamento máximo e mínimo são referentes ao valor que aparece no campo " $m m$ ”, seja ele atualizado ou dado pelo equipamento.

Estas configurações de deslocamento são parâmetros de fins de curso muito importantes que visam à segurança do ensaio e do equipamento, e devem ser corretamente selecionados e conferidos, pois evitam a colisão da garra com a caixa e o arrancamento completo da amostra.

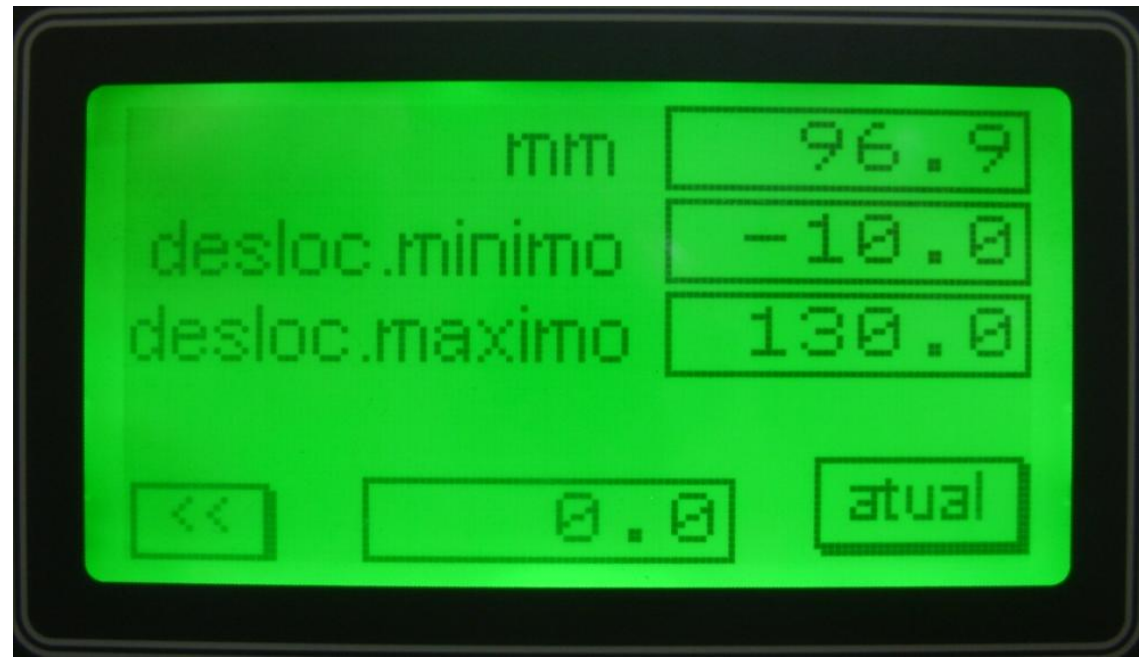

Figura 7.5 - Tela "Curso" do CLP.

O campo "Controle" da tela "Config." mostrado na Figura 7.6 a seguir apresenta configurações de ciclagem, da célula de carga do equipamento e da atuação automática do sistema hidráulico quanto à velocidade do pistão. No campo "Parada" podem ser selecionadas as opções "Sim" e "Não" para a parada ou não da garra na carga máxima ou mínima, selecionados através do campo "Maior" ou "Menor", respectivamente. O campo "Cte.Celula" 
apresenta um número que significa a constante de calibração da célula e deve ser mantido em 120, e o campo à direita pode ser selecionado entre "Normal" e "Alternada", indicando o funcionamento da célula quanto à tração e compressão, e para o caso de tração deve ser mantida a posição "Normal". O campo "N atuar" se refere à atuação ou não automática do CLP em relação à variação automática da velocidade do motor que ocorre quando o tempo de ciclagem programado não é alcançado, buscando tal tempo através da seleção "Atuar tempo".

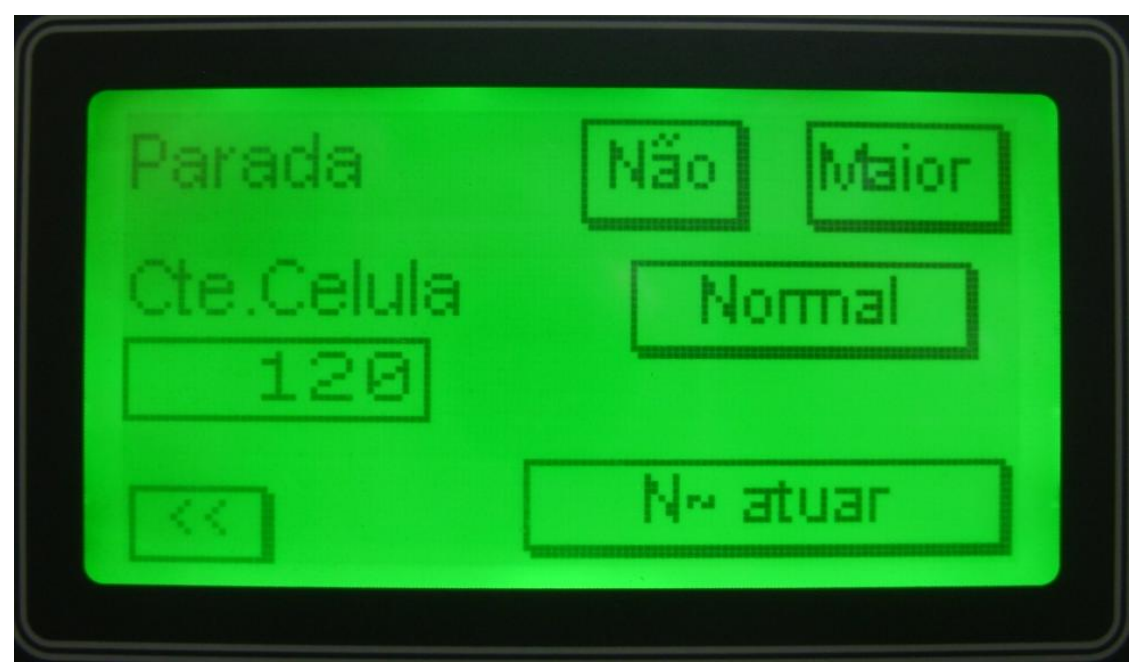

Figura 7.6 - Tela "Controle" do CLP. 